MARCELO XAVIER DE FREITAS CRESPO

\title{
DO CONHECIMENTO DA ILICITUDE EM FACE DA EXPANSÃO DO DIREITO PENAL
}

\author{
TESE DE DOUTORADO
}

Orientador: Professor Titular Vicente Greco Filho

FACULDADE DE DIREITO DA USP

SÃO PAULO

2012 


\section{DO CONHECIMENTO DA ILICITUDE EM FACE DA EXPANSÃO DO DIREITO PENAL}

Tese apresentada à Banca Examinadora da Faculdade de Direito da Universidade de São Paulo, como exigência parcial para a obtenção do título de Doutor em Direito, sob a orientação do Professor Titular Vicente Greco Filho.

FACULDADE DE DIREITO DA USP

SÃO PAULO

2012 
À Vanessa, pela diária transformação do nosso convívio na forma mais sublime de amor. 


\section{AGRADECIMENTOS}

Ao Professor Vicente Greco Filho pela confiança em aceitar-me como seu pupilo desde 2005 como aluno especial, sem o que não haveria trajetória acadêmica a ser seguida nas Arcadas. Agradeço, ademais, pelos ensinamentos constantemente transmitidos durante todo o tempo que pude acompanhá-lo nas aulas de graduação como seu assistente monitor e, ainda, nas aulas de pós-graduação, com profícuos debates, de forma que o aprendizado com o Professor Vicente mostra-se inestimável. Pela sempre atenciosa e perspicaz orientação, meus mais sinceros agradecimentos.

Aos professores Janaína Conceição Paschoal e Gustavo Henrique Ivahy Badaró, pelas fundamentais orientações e contribuições feitas por ocasião do exame de qualificação, sem as quais o árduo caminho que havia a trilhar seria ainda mais espinhoso.

Ao professor Renato de Mello Jorge Silveira, por incentivar-me e dispor de seu precioso tempo para tecer preciosas e fundamentais considerações que foram fundamentais para o desenvolvimento desta tese.

Aos professores do curso de "Especialización en Derecho" da "Fundación General de la Universidad de Salamanca" pelas aulas e pelo inestimável auxílio nas pesquisas durante o curso realizado em janeiro de 2011.

À Dalva, pela presteza, atenção e carinho de sempre.

Aos meus amigos, por ajudarem a lembrar de que existe vida além dos limites do trabalho.

À minha mãe, pela perfeição em dirigir minha vida enquanto menor e pelo amor sempre manifestado; ao meu avô Oscar, fonte inesgotável de casos e ensinamentos; à minha tia e madrinha Marília pelo apoio incondicional desde tenra idade; aos meus tios Marco e Cristina (também ao Oscar e ao Rafael) pelo apoio; e, finalmente, ao meu irmão Fernando e à Thaís, pelo descobrimento da nossa amizade e por trazer ao mundo a Maia.

À Vanessa, pelo amor, suporte e compreensão a cada ausência minha por conta dos estudos para elaboração desta tese.

À Deus, pela vida. 
“Cuanto menos desarrollado esté una dogmática, más imposible será la decisión de los tribunales, más dependerán del azar y de factores incontrolables la condena o la absolución. Si no se conocen los límites de un tipo penal, si no se ha establecido dogmáticamente su alcance, la punición o impunidad de una conducta no será la actividad ordenada y meticulosa que debería ser, sino una cuestión de lotería. Y cuanto menor sea el desarrollo dogmático, mas lotería, hasta llegar a la más caótica y anárquica aplicación de un derecho penal del que - por no haber sido objeto de un estúdio sistemático y científico - se desconoce su alcance y límite" (Enrique Gimbernat Ordeig) 


\section{RESUMO}

Neste trabalho buscou-se revisitar os pressupostos do conhecimento da ilicitude pela doutrina, inserindo-os no contexto da teoria do delito, especialmente no que tange à problemática da expansão do direito penal, tendo-se em conta a existência de bens jurídicos difusos, a inflação do direito penal, questões relativas às normas penais em branco e a elementos normativos do tipo, além de questões envolvendo o Direito Penal e o Administrativo Sancionador. Pretendeu-se, ainda, relacionar o conhecimento da ilicitude com o erro de proibição, ilustrando como a jurisprudência pátria aborda o tema.

Palavras-chave: Conhecimento da ilicitude - Ilicitude - Antijuridicidade - Expansão do Direito Penal - Teoria do Delito - Direito Administrativo Sancionador 


\begin{abstract}
This paper seeks to revisit the assumptions of knowledge of illegality by the doctrine, placing it in the context of the theory of the crime, especially regarding the issue of expansion of criminal law, taking into account the existence of legal goods diffuse, the inflation of criminal law, criminal law issues relating to white and normative elements of the type. The intention was also to relate the knowledge of illegality with the error of prohibition, illustrating how the Brazilian Courts deals with the subject case.
\end{abstract}

Keywords: Illegality - Unlawfulness - Expansion of criminal law - Theory of crime Administrative Sanctioning System 


\section{RIASSUNTO}

Il presente documento si propone di rivisitare i presupposti di conoscenza dell'antigiuridicità del fatto dalla dottrina, collocandolo nel contesto della teoria del reato, soprattutto per quanto riguarda il problema della espansione del diritto penale, tenendo conto in particolare l'esistenza di beni giuridici diffondere l'inflazione del diritto penale, le questioni di diritto penale in materia di elementi bianchi e normativa del tipo. L'intenzione era anche di mettere in relazione la conoscenza dell'antigiuridicità del fatto con l'errore di divieto, che illustra come i tribunalli brasiliani affronta il caso soggetto.

Paroles-chiave: Espansione del Diritto Penale - Illiceità - Antigiuridicità - Teoria del reato - Diritto sanzionatorio amministrativo 


\section{SUMÁRIO}

1. DA TEORIA DO DELITO E O CONHECIMENTO DA ILICITUDE 14

1.1. Ponderações iniciais .14

1.2. O conceito unitário de delito e a relação entre tipo penal e ilicitude ............................................... 19

1.3. O conceito bipartido de delito e a relação entre tipo penal e ilicitude .............................................22

1.4. O conceito tripartido de delito e a relação entre tipicidade e ilicitude ...............................27

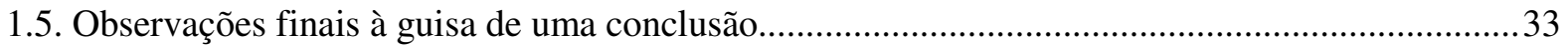

2. FUNDAMENTOS TEÓRICOS DO CONHECIMENTO DA ILICITUDE. 36

2.1. Ponderações iniciais .36

2.2. Considerações sobre a terminologia: antijuridicidade, ilicitude, injusto e antinormatividade. 39

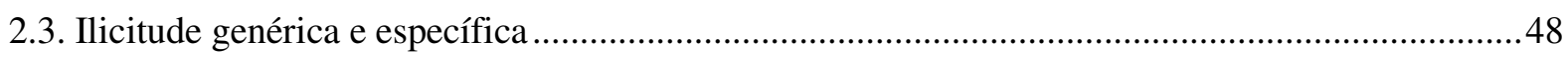



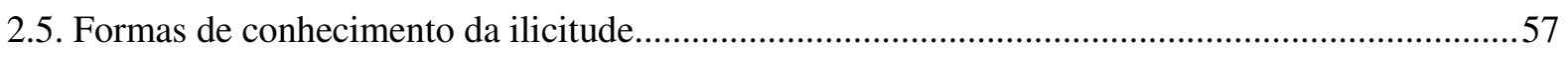

2.5.1. A potencialidade ou eventualidade do conhecimento ..........................................................5

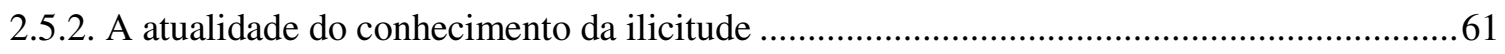

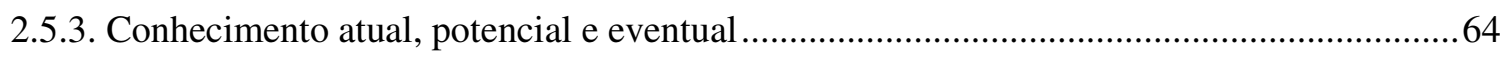

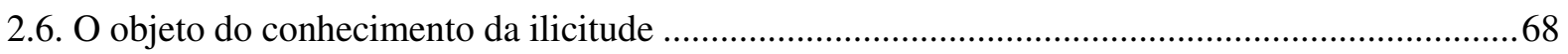

3. O FENÔMENO DA EXPANSÃO DO DIREITO PENAL ….............................................. 72

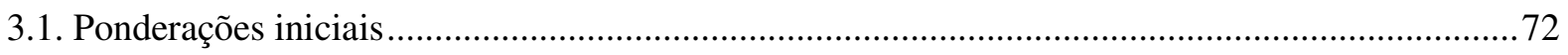

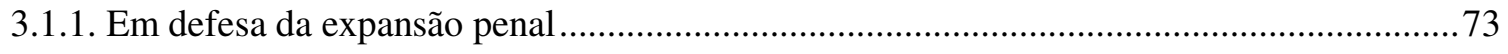

3.1.2. Sobre as teses contrárias à expansão: o discurso de resistência e as críticas da Escola

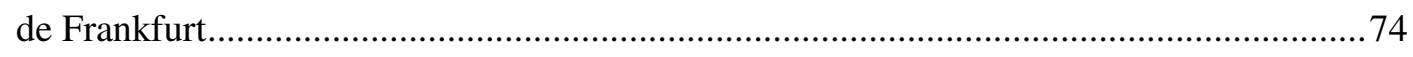

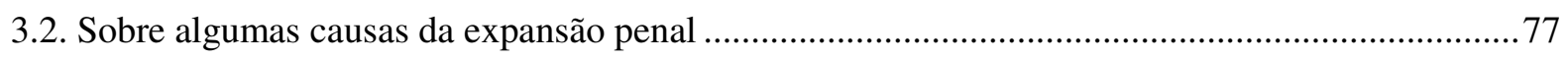

3.2.1. Algumas palavras sobre os medos e as inseguranças sociais .............................................. 78

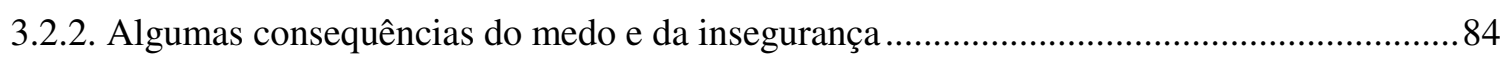

3.2.3. O aspecto vitimológico-social advindo da expansão penal .................................................. 86

3.2.4. Sobre o descrédito de outras instâncias de proteção ........................................................... 89

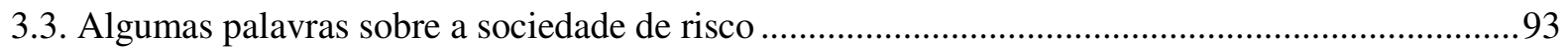

3.3.1. Da sociedade de risco como aproximação político-criminal ao direito penal.......................95 
3.3.2. Algumas palavras sobre bem jurídico no contexto da expansão e da sociedade de

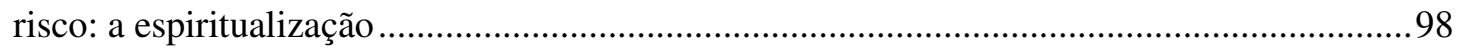



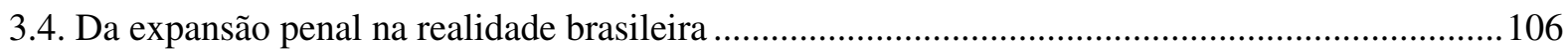

4. A DISTINÇÃO ENTRE O DIREITO ADMINISTRATIVO SANCIONADOR E O DIREITO PENAL COMO DEMONSTRAÇÃO DA CLARA DIFICULDADE EM



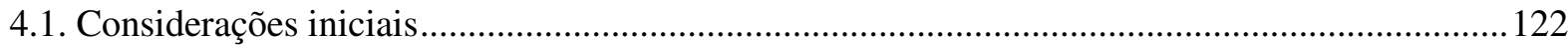

4.2. O Direito de Intervenção e o Direito de Velocidades no contexto do Direito Administrativo Sancionador

4.3. Um panorama do estado atual do debate quanto aos limites entre o direito penal e o administrativo sancionador

4.4. Sobre critérios de distinção.

4.5. Algumas palavras sobre a distinção do direito penal e administrativo sancionador na Espanha

4.6. O direito administrativo sancionador como direito punitivo no direito comparado

4.7. Sobre a inexistência de uma política jurídica administrativo-sancionadora: o jus puniendi como expressão das ilicitudes penal e administrativa

4.8. A racionalidade ética: os princípios da lesividade, fragmentariedade e a busca por uma

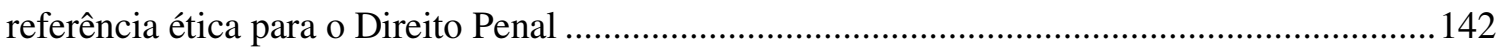

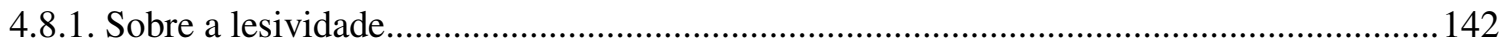

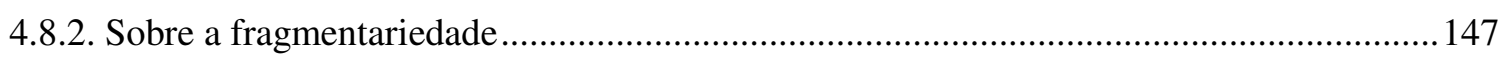

4.8.3. Sobre a busca por uma referência ética no âmbito penal ................................................ 152

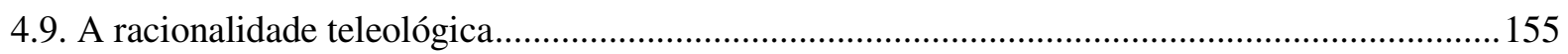

4.9.1. Breves, porém necessárias, reflexões sociológicas .......................................................... 158

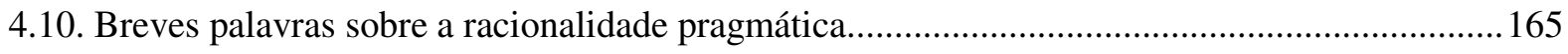

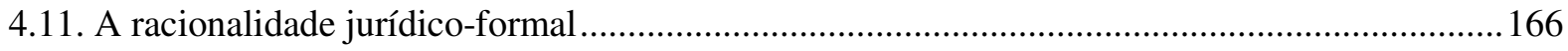

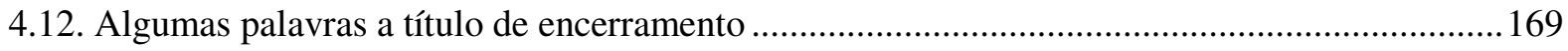

\section{DO ERRO E SUA RELAÇÃO COM O CONHECIMENTO DA ILICITUDE ...............172}

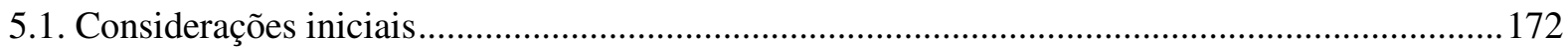

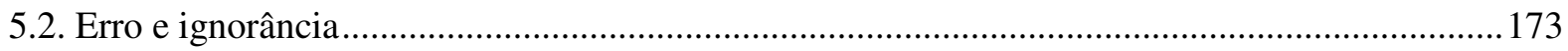

5.3. Desconhecimento do ilícito versus Desconhecimento da norma ..................................................176



5.5. Dos dispositivos legais relacionados ao erro de tipo e de proibição ............................................182 
5.6. Formas ou modalidades do erro de proibição admitidos no Brasil

5.7. Erro de proibição e bem jurídico num contexto de expansão do Direito Penal 185

5.8. Do erro de proibição e sua repercussão em algumas decisões judiciais no Brasil

5.9. As teorias do dolo e da culpabilidade no contexto das normas penais em branco e a questão do erro

5.10. Síntese das concepções doutrinárias relativas ao erro de proibição 


\section{INTRODUÇÃO}

O presente trabalho pretende revisitar os pressupostos do conhecimento da ilicitude, inserindo-os no contexto da teoria do delito, em especial no que tange à problemática da expansão do direito penal, com estudos que remetem às doutrinas espanhola, alemã e brasileira. Para tanto, foram considerados aspectos como a inflação do direito penal, questões relativas às normas penais em branco e a elementos normativos do tipo, sem esquecer-se dos bens jurídicos difusos. Pretendeu-se, ainda, relacionar o conhecimento da ilicitude com o erro de proibição, ilustrando como a jurisprudência pátria aborda o tema.

Assim, no primeiro capítulo busca-se a exposição dos conceitos analíticos do crime (unitário, bipartido e tripartido) e a inserção do conhecimento da ilicitude no contexto da teoria do crime. É que não se pode negar que o Direito Penal foi atingido, no tempo, por influências diretas de diferentes Escolas filosóficas que sempre buscaram trazer maior efetividade na sua aplicação ante as mudanças sociais. Neste ponto verifica-se a importância de se relacionar o conhecimento do ilícito à teoria do delito porquanto não apenas filosófica, mas também dogmaticamente a implicações e problemas conforme se prefira uma ou outra orientação.

Então, ao pretender-se discorrer sobre o tema, faz-se obrigatoriamente uma volta às origens do Direito Penal e, ainda, às suas teorias mais modernas e seus entendimentos de vanguarda, haja vista que somente baseado no que se pressupõe proibido cultural e positivamente se pode falar validamente em reprovação de uma determinada conduta.

Eis, então, no capítulo 2, a exposição dos fundamentos teóricos, portanto a apresentação de aspectos fundamentais, para o estudo do tema, abordando-se inicialmente a problemática que envolve a terminologia empregada tendo em vista a diversidade mencionada pela doutrina, como antijuridicidade, ilicitude, injusto e antinormatividade.

Segue-se o trabalho, ainda no contexto dos fundamentos teóricos, registrando-se comentários sobre as ilicitudes genérica e específica, objetiva e subjetiva, passando-se, ainda, pelas formas de conhecimento da ilicitude - atual e potencial - até chegar a traços do objeto do conhecimento da ilicitude.

Ademais, no capítulo 3 verifica-se o momento de imiscuir-se nos estudos relativos ao fenômeno da expansão do direito penal. Assim, são destacados importantes aspectos, 
como as suas causas e questões relativas à globalização, tudo com vistas à política criminal (ou falta dela) em tempos de expansão. Neste ponto afirma-se a necessidade desta incursão porque, em face da expansão penal é inegável a mudança na perspectiva de aplicação da lei penal, havendo o que se convencionou denominar "inflação legislativa" e, ainda, a proteção penal de interesses transindividuais. Outros fatores vislumbrados na expansão, como o descrédito em instâncias de proteção e o aspecto vitimológico-social notado desde então também são comentados. Tudo com vistas a demonstrar alterações sócio-jurídicoculturais que certamente trazem reflexos no tocante ao conhecimento da ilicitude.

No capítulo 4 discorre-se sobre as imensas dificuldades em delimitar-se diferenças entre o Direito Penal e o Administrativo Sancionador. Partindo-se, então, das considerações feitas no capítulo anterior - sobre a expansão penal - passou-se a estudar problemas relativos aos limites de cada instância punitiva, uma vez que sua mescla traz enormes dificuldades para que se possa entender a que se refere a ilicitude penal e, em última análise, conhecê-la.

Igualmente não poderia deixar de comentar outra importante face do conhecimento da ilicitude: o erro, em especial o erro de proibição. Não seria possível comentar o conhecimento da ilicitude sem que se debruçasse, em algum momento, sobre o erro de proibição, instituto imediatamente a ele relacionado. Por isso no capítulo 5 estuda-se essa temática, inclusive apresentando questões concernentes aos bens jurídicos (especialmente os transindividuais) e, ainda, apresentam-se curiosas questões sobre a aplicação de uma teoria do dolo ou da culpabilidade para a aplicação das consequências do erro de proibição. Por fim, trazem-se à colação alguns julgados pesquisados nos tribunais brasileiros, no intuito de demonstrar como o assunto vem sendo tratado pelo Judiciário, o que, particularmente pode surpreender o leitor, que notará ser difícil encontrar julgados sobre o tema, além de, por vezes, ele não ser abordado com o rigorismo científico esperado.

Verifica-se, pois, que discorrer sobre a ilicitude e o que dela se (des)conhece é tema dos mais árduos na dogmática penal justamente pela íntima ligação com o que se entende por função do direito penal, o que pode envolver, ainda, discussões sobre o dolo, a culpa, o erro, culpabilidade, entre outras. Um dos principais fatores de dificuldade resvala no fato de que, a pretexto de se discorrer sobre os fundamentos e problemas relacionados ao conhecimento da ilicitude num contexto de expansão, não pode o trabalho percorrer todo o direito penal indistintamente. 
Ademais, trata-se de tema tido como essencial por renomados doutrinadores e que remonta ao questionamento sobre o que seja "conhecimento" e "ilicitude", problema que ganha contornos de autonomia e que, apesar disso, não parece ter sido percebido desta forma pela doutrina, haja vista a escassez de trabalhos específicos.

Ponto de difícil contextualização, mas que mereceria trabalho à parte seria a questão cultural e comunicativa relativa aos tipos penais no que tange à linguística e até mesmo sociologia jurídica. Todavia, não é esse o foco do trabalho, que se posta na colocação histórica sobre o conhecimento da ilicitude, inclusive na teoria do delito, além dos reflexos que a expansão do direito penal causa e causou quanto à possibilidade de que se conheçam regulamentações administrativas, exigindo grande conhecimento técnico por parte dos cidadãos.

Enfim, o incremento de tipificações penais na busca de punição a estados prévios de lesão a bens jurídicos, fenômeno conhecido como "expansão do direito penal", parece criar situações limite entre o que se pode considerar estar sob erro de tipo ou mesmo erro de proibição, fazendo-se surgir o questionamento sobre a existência de ilicitudes penal e administrativo-sancionadora como autônomas. Em outros termos, até que ponto a incriminação por meio de tipos de perigo e normas penais em branco pode direcionar o agente a situações de erro que não se pode apontar precisamente? Como conhecer a ilicitude numa sociedade em que o direito penal expandiu-se demasiadamente e há inúmeras regras administrativas que, muitas vezes, se confundem com a norma penal?

Como se pode notar, o tema é justificado pela enorme problemática que pode gerar ao Direito Penal, já que inúmeros assuntos podem ser abarcados, como os acima mencionados.

Ademais, tanto a abordagem questionando o conhecimento da ilicitude em face das características da expansão penal, como o fato de haver poucos trabalhos no vernáculo garante o ineditismo da tese, conferindo a necessária contribuição original ao tema tratado. 


\section{DA TEORIA DO DELITO E O CONHECIMENTO DA ILICITUDE}

\subsection{Ponderações iniciais}

Antes de comentar de forma mais aprofundada o ponto fulcral desta tese, mister se faz apresentar algumas ponderações iniciais quanto à dogmática penal e à teoria do delito, a fim de que, mais tarde, possam ser identificadas e localizadas precisamente as discussões sobre a consciência da ilicitude.

Assim, a dogmática penal é a disciplina responsável pela interpretação, sistematização e desenvolvimento das opiniões científico-doutrinárias em face das disposições legais. É reconhecida por Roxin como de fundamental importância para a formação universitária na medida em que as situações submetidas a estudo pelos universitários exigem uma análise sobre a atribuição de responsabilidade aos envolvidos, o que somente se pode obter com sólidos conhecimentos dogmáticos do Direito Penal. ${ }^{1}$

Deve-se mencionar, ainda, que a dogmática penal distingue-se de meras abordagens históricas, dos estudos de direito comparado e, ainda, da política criminal, tendo em vista que o seu objetivo não é a demonstração de como o Direito Penal é, mas de como deveria ser para que possa atingir seus fins. ${ }^{2}$

Além disso, uma das principais manifestações da dogmática se dá no âmbito da teoria geral do delito, que representa o núcleo da parte geral do direito penal. ${ }^{3}$ Todavia, uma de suas mais difíceis missões consubstancia-se no desenvolvimento de um sistema, isto é, na reunião de conhecimentos fundados em uma ideia e ordenados segundo princípios, buscando-se que sua congregação resulte num todo concreto. ${ }^{4}$ Para que se forme um sistema não é suficiente, pois, que sejam expostas e tratadas sucessivamente as proposições doutrinárias, mas que se estruturem os estudos de modo a atingir uma totalidade organizada apta a expor claramente a conexão de dogmas internos. ${ }^{5}$

\footnotetext{
${ }^{1}$ ROXIN, Claus. Derecho penal: parte general. 2. ed. Trad. Diego-Manuel Luzón Peña, Miguel Diaz e Garcia Conlledo e Javier de Vicente Remesal. Madrid: Civitas, 1997. t. 1, p. 192.

${ }^{2}$ Id., loc. cit.

${ }^{3}$ GRECO FILHO, Vicente. Crime: essência e técnica. Boletim do Instituto Manoel Pedro Pimentel, São Paulo, v. 5, n. 21, p. 11-12, jul./set.. 2002. ${ }^{4}$ Id. Ibid., p. 193.

${ }^{5}$ SCHÜNEMANN, Bernd. El sistema moderno de derecho penal: cuestiones fundamentales. Trad. e introd. Jesús-Maria Silva Sánchez. Madrid: Tecnos, 1991. 31, n.1; N del T.
} 
Neste sentido, a primeira tarefa da teoria geral é a apresentação de um conceito de delito que comporte tudo o que seja comum aos fatos, considerando-se a violação da lei e, consequentemente, sua punição. Mas, para tanto, é forçoso rememorar que há diferentes conceitos de delito, podendo-se analisá-los sob a perspectiva formal (é o que a lei determina que seja - nullum crimen sine lege), material (aquilo que a sociedade entende como reprovável, é o substrato) e, ainda, a científica ou analítica (decomposição em elementos/ institutos). E, neste ponto, deve-se dizer que embora nas legislações se verifique o uso de expressões como "dolo", "culpa", "culpabilidade" etc., elas não se ocupam de descrever expressamente todos os elementos necessários para a formação científica de um delito. Quando muito, referem-se a algumas características.

Quanto ao desenvolvimento da teoria do delito, um estudo, ainda que superficial sobre o que representaram as Escolas Penais, mostra a longa evolução que vem sofrendo o Direito Penal. É possível notar que, historicamente, a evolução da teoria do delito acompanhou de perto as alterações quanto às ideias desde o positivismo, passando-se pelo neokantismo, ontologismo, até chegar ao funcionalismo. ${ }^{6}$ Resta claro, pois, que seu desenvolvimento acompanhou as ideologias que se verificavam em suas respectivas épocas.

De qualquer forma, nem sempre houve uma estrutura científica sobre o que devesse representar o delito. Foi com o Marquês de Beccaria, com sua clássica obra datada de 1764 que o Direito Penal ganhou os contornos mínimos como conhecemos. Naquela época a sociedade recebia influência de pensamentos racionais, com viés contratualista uma vez que a cessão de parte da liberdade de cada um era a condição necessária para que se tivesse um convívio social adequado. Eram injustas quaisquer sanções que fossem além dessa necessidade.

As ideias de Beccaria tiveram grande importância para a política criminal da época, prestando-se como pilar para a construção de um Direito Penal de mais garantias aos cidadãos. Suas ideias têm guarida especialmente na defesa da legalidade dos delitos e

\footnotetext{
${ }^{6}$ Para estudos mais aprofundados sobre a evolução das Escolas Penais em face das ideologias de suas épocas, veja-se: MIR PUIG, Santiago. Introducción a las bases del derecho penal. Bosch: Barcelona, 1976; HIRSCH, Hans Joachim. El desarrollo de la dogmática penal después de Welzel. In: Derecho penal: obras completas. Livro Homenaje. Buenos Aires: Rubinzal-Culzoni Editores, 1999. t. 1, p. 13; HASSEMER, Winfried. La ciencia jurídico-penal en la Republica Federal Alemana. Anuário de Derecho Penal y Ciencias Penales, t. 46, fasc. 1, p. 44, jan./abr. 1993; SANCINETTI, Marcelo. Prólogo. Homenage a la memoria de Hans Welzel a los 20 años de su fallecimiento. In: JAKOBS, Gunther; STRUENSSE, Eberhard. Problemas capitales del derecho penal moderno: libro homenagem a Hans Welzel. Buenos Aires: Hamurabi, 1998. p. 23; CAMARGO, Antonio Luis Chaves. Imputação objetiva e direito penal brasileiro. São Paulo: Cultural Paulista, 2002. p. 26; SAINZ CANTERO, José. La ciencia del derecho penal y su evolución. Barcelona: Bosch, 1975. p. 79.
} 
também das penas, além da utilidade, humanização e proporcionalidade destas e, ainda, da separação de funções do Estado e da isonomia. Mesmo assim, não se considera que referido pensador tenha sido o criador da ciência penal atual. Suas ideias influenciaram, sem dúvida, a política criminal e a criminologia, e não se discute que tenha dado sustentáculo às bases que, mais tarde, auxiliaram na construção do ramo penal fundado em um sistema de garantias aos sujeitos. Em apertada suma, Beccaria propôs os fundamentos para o Direito Penal no contexto de um Estado de Direito, por isso sua importância. ${ }^{7}$ Nessa perspectiva fundante de uma teoria geral, há quem aponte seu início baseado nos estudos de outro autor: Feuerbach. ${ }^{8}$

Assim, a chamada "teoria do delito" é a reunião sistemática de elementos, fruto da doutrina jurídico-penal, na busca por princípios básicos do ramo tradicionalmente sancionador e sua articulação em um sistema coerente. Será diante de uma teoria geral que competirá ao jurista elaborar o conceito analítico mencionado. Também se pode dizer que, desde meados do século XIX, tem-se dado mais atenção a estudos sobre o tema, isto é, sobre o conceito analítico de crime. ${ }^{9}$

Por outro lado, deve-se frisar que não há, atualmente, consenso quanto a essa conceituação, e os registros históricos mostram não ter havido qualquer consenso sobre a utilidade em se formar um conceito analítico de crime, com elementos decompostos, tendo-se verificado, inclusive, reação a essa tentativa. Esse movimento representou uma reação ao logicismo e ao racionalismo e, ainda, de acordo com Pagliaro e Bettiol, havia várias diretrizes filosóficas, sob a denominação de irracionalismo, que entendiam ser desprovidas de razão as explicações sobre os fatos sociais que defendiam e que era preciso atribuir maior relevância ao sentimento, crença e religião. ${ }^{10}$

Por outro lado, embora se tivesse notado reação quanto à necessidade da elaboração de um conceito analítico, Fiandaca e Musco se posicionaram favoravelmente ao estudo, manifestando a necessidade da obtenção de certeza jurídica justamente pela decomposição

\footnotetext{
${ }^{7}$ Nesse sentido, BUSTOS RAMIREZ; Juan. Introducción al derecho penal. Bogotá: Temis, 1994. p. 97.

${ }^{8}$ TAVARES, Juarez. Culpabilidade: a incongruência dos métodos. Revista Brasileira de Ciências Criminais, São Paulo, ano 6, n. 24, out./dez. 1998.

${ }^{9}$ Por exemplo, na Itália, há distinção entre crimes, delitos e contravenções, conforme dispõe o art. 39 do Código Penal daquele país. No entanto, essa diferenciação se mostra puramente formal e conta como critérios distintivos somente as penas aplicadas a cada uma das espécies. Neste sentido: MARINUCCI, Giorgio; DOLCINI, Emilio. Manuale di diritto penale: parte generale. 2. ed. Milano: Giuffrè, 2006. p. 120 e ss.

${ }^{10}$ BATALHA, Wilson de Souza Campos; RODRIGUES NETTO, Sílvia Marina L. Batalha de. Filosofia jurídica e história do direito. Rio de Janeiro: Forense, 2000. p. 239.
} 
em elementos. ${ }^{11}$ Assim, a ideia da desnecessidade do conceito técnico composto por elementos bem delineados perdeu força, vendo-se superada, porque houve maior percepção da utilidade em que fossem apontados, individualmente, os componentes do crime. Em outras palavras, significa dizer que o crime precisa ser conhecido em sua inteireza, o que somente seria obtido com o surgimento de uma teoria geral, sendo esta capaz de apontar diferentes visões sobre fatos, deixando de serem verificáveis apenas no mundo natural para serem analisados normativamente sob a óptica do ordenamento jurídico. Foi isto o que levou à existência de conceitos de delito sob a forma analítica.

Apesar disso, Antolisei mostrou preocupação em que fossem obtidos resultados práticos quanto à orientação metodológica analítica. Entendeu que o estudo por meio de decomposição em itens individualmente considerados fragmentaria os elementos do delito, e, embora assim contasse com maior autonomia, poderia fazer com que se incorresse em abstrações desnecessárias e pouco elucidativas. ${ }^{12}$

O fato é que o conceito analítico de delito, sendo formulado pela decomposição teórica de diferentes categorias jurídicas, oferece uma compreensão mais aprofundada do objeto de estudo, tendo este tipo de abordagem surgido da transformação do fenômeno ontológico do crime em um conceito normativo. Essa transformação é importante para que se obtenha a maior coerência possível quanto à intervenção normativa estatal em face da criminalidade.

Por outro lado, cabe mencionar que ao estipular um conceito analítico de crime não significa que, peremptoriamente, fossem desconsideradas outras ópticas sobre o tema, especialmente estudos criminológicos e sociológicos, até mesmo porque o estudo da criminalidade é algo reconhecidamente complexo e, cada uma dessas abordagens tem sua função e validade. ${ }^{13}$ É precisamente nesse sentido que há tempos Roxin vem fazendo ponderações, alegando ser fundamental o estudo da dogmática penal com a integração das perspectivas político-criminais e criminológicas, para que se possa elaborar um

\footnotetext{
${ }^{11}$ FIANDACA, Giovanni; MUSCO, Enzo. Diritto penale: parte generale. 5 ed. Bologna: Zanichelli, 2007. p. 173.

${ }^{12}$ ANTOLISEI, Francesco. Manuale di diritto penale: parte generale. 14. ed. agg. e integrata a cura di Luigi Conti. Milano: Giuffrè, 1997. p. 206-207.

${ }^{13}$ Precisamente, Roxin afirma que "Con todo esto se pone de manifiesto que el camino acertado sólo puede consistir en dejar penetrar las decisiones valorativas político-criminales en el sistema del Derecho penal, en que su fundamentación legal, su claridad y legitimación, su combinación libre de contradicciones y sus efectos no estén por debajo de las aportaciones del sistema positivista formal proveniente de Liszt." (ROXIN, Claus. Politica criminal y sistema del derecho penal. 2. ed. 1. reimpr. Traducción e introducción de Francisco Muñoz Conde. Buenos Aires: Hammurabi, 2002. p. 49).
} 
ordenamento jurídico capaz de realizar sua função teleológica de regulação social e de proteção aos bens jurídico-penais. ${ }^{14}$

Regressando brevemente aos conceitos de delito, mencionou-se haver, ao lado da concepção analítica, outras duas: a formal e a material.

Sob a óptica formal, Manzini entende que o crime é um fato humano (ação ou omissão) com o qual se viola um preceito jurídico que traz consigo uma sanção coercitiva indireta (pena). ${ }^{15}$ Trata-se de um conceito formado por elementos parciais e condicionado à punibilidade. Por seu turno, embora Gallo reconheça o conceito formal, entende que os interesses a serem tutelados definem o objeto jurídico do delito num conceito material. ${ }^{16}$ Todavia, Antolisei já se posicionou sobre a lesão ao bem jurídico não significar o imediato apontamento do conceito substancial de delito, porque tais ofensas também pertencem a outros ramos jurídicos, como o civil e o administrativo. ${ }^{17}$

Maggiore concebeu o delito de forma substancial, por ele denominado "sentido real", sendo, então, toda a ação que ofende gravemente a ordem ético-jurídica e, por isso, merecedora de pena. ${ }^{18}$ Para este autor, a concepção "real" do delito se presta a apontar seu valor objetivo, tendo como ponto central do conceito substancial o dever ético de respeito às normas jurídicas. Bettiol, no entanto, tem posicionamento diverso, vinculando a ideia substancial do delito aos bens jurídicos. ${ }^{19}$

A passagem da dogmática penal por diferentes tendências também abrangeu a escola clássica de Carrara, que representou "a expressão definitiva da corrente clássica na Itália. Não tem Carrara a originalidade de alguns de seus predecessores. O que nele se distingue é a glória jurídica, o poder da dialética com que expõe e justifica seu programa

\footnotetext{
${ }^{14}$ ROXIN, Claus. Politica criminal y sistema del derecho penal, cit., p. 49.

${ }^{15}$ MANZINI, Vicenzo. Trattato di diritto penale italiano. Torino: Unione Tipografico Editrice Torinese, 1950. v. 1, p. 530.

${ }^{16}$ GALLO, Marcello. Il reato nel sistema degli illeciti. Rivista Italiana di Diritto e Procedura Penale, Milano, nuova serie, anno 42, fasc. 3, p. 769, lugl./sett. 1999. E, quanto ao objeto jurídico afirmou que "Si parla di interesse tutelato e non di bene. Spesso i due termini sono usati in differentemente: (...). Parleremo di interesse tutelato e non di bene perché l' ordinamento giuridico tutela un bene soltanto in relazione ai bisogni, alle tensioni, alle espettative di un soggeto umano: Il concetto di interesse implica quello di relazione tra un soggetto ed un oggetto di valutazione."

${ }^{17}$ ANTOLISEI, Francesco. op. cit., p. 168-169.

${ }^{18}$ MAGGIORE, Giuseppe. Derecho penal. Prefacio por el Dr. Sebastián Soler. Traducción de la 5 ed. por el padre José J. Ortega Torres. Bogotá: Temis, 1954. v. 1, p. 251.

${ }^{19}$ BETTIOL, Giuseppe. Direito penal. Tradução de Paulo José da Costa Jr. e Alberto Silva Franco. São Paulo: Ed. Revista dos Tribunais, 1966. v. 1, p. 218-219. Nesse sentido "Na contenda que se trava, pois, em torno da noção de crime, isto é, se ela deve ser constituída pela lesão de um bem jurídico ou pela violação de um dever, deve-se dar prevalência à lesão do bem jurídico porque a noção do dever não pode possuir uma autonomia funcional própria."
} 
e a admirável capacidade de sistematização, que fez dele o expositor máximo e consolidador da escola e um dos maiores penalistas de todos os tempos.

Também não se pode deixar de mencionar que foram os estudos ortodoxos de Rocco, no início do século XX, que repudiaram a influência do jusnaturalismo, limitando o objeto de estudo do direito penal que deu início às novas concepções quanto à ilicitude. ${ }^{21}$ No entanto, houve críticas ao método apresentado, tendo surgido verdadeira gama de concepções que se sucederam na análise do delito, como ocorreu com o realismo jurídico, o axiologismo normativo e concreto, a teleologia no estudo do Direito Penal, entre outras tendências teóricas. ${ }^{22}$ Miguel Reale Júnior teceu duras críticas a esta teoria, afirmando que ela foi responsável pelo empobrecimento do ramo penal e por vincular-se demais ao formalismo, além de promover um distanciamento das fontes materiais do delito, determinando-se um dedutivismo lógico-abstrato. ${ }^{23}$

Foi possível notar, então, ideias no sentido de desenvolver uma teoria que fosse capaz de facilitar a resposta do Estado ao jurisdicionado. ${ }^{24}$ Nessa perspectiva é que se aponta, abaixo, a formação do injusto penal nas diferentes concepções teóricas, unitária, bipartida e tripartida. ${ }^{25}$ Tudo com vistas ao depois, à localização e discussão do elemento central deste trabalho: o conhecimento da ilicitude.

\subsection{O conceito unitário de delito e a relação entre tipo penal e ilicitude}

O conceito unitário de crime surgiu com base nas críticas ao formalismo da dogmática penal. Bettiol afirmou que tal conceito surgiu como reação às correntes que seccionaram o delito em elementos numericamente relevantes, porém todos equiparados no

\footnotetext{
${ }^{20}$ BRUNO, Aníbal. Direito penal: parte geral. 5. ed. rev. e atual. por Raphael Cirigliano Filho. Rio de Janeiro: Forense, 2003. t. 1, p. 54.

${ }^{21}$ ROCCO, Arturo. El problema y el método de la ciencia del derecho penal. Versión de Rodrigo Naranjo Vallejo. Bogotá: Temis, 1982. p. 6 e ss.

${ }^{22}$ REALE JÚNIOR, Miguel. Teoria do delito. São Paulo: Ed. Revista dos Tribunais, 1998. p. 112 e ss.

${ }^{23}$ Id. Ibid., p. 112 e ss.

${ }^{24}$ Veja-se a constatação de Schünemann: "el pleno de la Corte Suprema italiana se ha referido, para rechazarlo, al sistema juridico-penal alemán construido sobre la distinción entre injusto y culpabilidad, como una construcción que necesariamente se há generado al nivel de la especulación dogmática, y que no há encontrado aquel desarollo ulterior que hubi ese permitido hacerla aceptable en él ambito de la práctica forense." (SCHÜNEMANN, Bernd. Obras. Buenos Aires: Rubinzal - Culzoni Editores, 2009. t. 1, p. 329).

${ }^{25}$ Relativamente quanto à preferência italiana, vide DIAS, Jorge de Figueiredo. O problema da consciência da ilicitude em direito penal. 5. ed. Coimbra: Coimbra Ed., 2000. p. 70.
} 
mesmo patamar de questionamento. ${ }^{26}$ Assim, defendia a ideia de que a (pretensa) unidade proposta ao crime só se mostra presente num plano naturalístico. ${ }^{27}$ Entendia-se, num primeiro momento, que a divisão do delito em vários elementos retirava a unidade deste conceito. Apesar desse posicionamento, resta patente que a crítica à concepção unitária não significa a absoluta rejeição do uso de conceitos naturalísticos, até mesmo por causa da divisão analítica de seus elementos. Então, o delito passou a ser visto como uma unidade, mas, apesar disso, ainda era possível analisá-lo sob diferentes ângulos. ${ }^{28}$

Para Bettiol, havia esboços do conceito teórico unitário já nas obras de Carnelutti e de Moro, embora se diga que nenhum dos dois efetivamente o adotou, porque apesar de definirem o crime de forma unitária, analisavam-no sob a óptica de aspectos fragmentados. $^{29}$ Nesse sentido, Carnelutti afirmava que os elementos do delito não existiam isolados na teoria, isto é, ganhavam significância quando reunidos num conceito unitário de crime. ${ }^{30}$ Por isso, diferenciava elementos de requisitos, sendo os primeiros as qualidades do agente e sua relação com o sujeito passivo, ao passo que requisitos seriam o modo de ser de cada elemento do crime, do qual a lei faz depender a existência ou a gravidade do crime. ${ }^{31}$ Ademais, esclareceu que o viés subjetivo da ilicitude não deveria ser conhecido como "culpabilidade", mas como "desobediência”, englobando o dolo e a culpa. ${ }^{32}$

Moro, por sua vez, também teve seus estudos relacionados à teoria unitária e afirmou que a descrição típica de uma conduta deveria ser plena de significado jurídico, isto é, a norma deveria descrever o fato típico e valorar, conjuntamente a proibição, de modo que não haveria ação ou omissão dotada de relevância penal que não fosse contrária ao direito. ${ }^{33}$ Também criticou a distinção ideal entre tipo e ilicitude, apontando ser arbitrária a separação do elemento descritivo e a valoração constante no tipo penal, representando a divisão de uma realidade unívoca, portanto indivisível. ${ }^{34}$ Por isso, considera ser melhor a concepção unitária de crime.

\footnotetext{
${ }^{26}$ BETTIOL, Giuseppe. op. cit., v. 1, p. 220.

${ }^{27}$ Id. Ibid., p. 223.

${ }^{28}$ MAGGIORE, Giuseppe. op. cit., v. 1, p. 270.

${ }^{29}$ BETTIOL, Giuseppe. op. cit., v. 1, p. 220 e ss. Vide, ainda, PAGLIARO, Antonio. Trattato di diritto penale: il reato. Milano: Giuffrè, 2007. v. 2, p. 61.

${ }^{30}$ CARNELUTTI, Francesco. Teoria generale del reato. Secondo migliaio. Padova: CEDAM, 1933. p. 69.

${ }^{31}$ Id. Ibid., p. 82.

${ }^{32}$ Id. Ibid., p. 29-30.

${ }^{33}$ MORO, Aldo. La antijuridicidad penal. Traducción directa del italiano por Diego A. Santillan. Buenos Aires: Editorial Atalaya, 1949. p. 189-190.

${ }^{34}$ Id. Ibid., p. 187 e ss.
} 
Pagliaro entendia, igualmente, que o crime não poderia ser analisado por meio de seus elementos particulares, porque sua divisão em partes significaria algo como causar a morte da unidade. Apesar disso, adotava explicação fundada na bipartição do delito. ${ }^{35}$ Também advertia sobre a confusão possivelmente existente entre a concepção unitária de delito com a tentativa de unificar o conceito pelo uso de termos como "elementos do crime" por "aspectos do crime" ${ }^{36} \mathrm{E}$, apesar de adotar uma concepção tripartida de delito, Maggiore afirmou haver um conceito unitário de crime (em termos jusnaturalistas). ${ }^{37}$

Todas estas concepções defendem que o crime não deve ser separado em partes, de modo que eventual decomposição em diferentes elementos, embora tente representar a complexa realidade, não se mostra exitosa por ser esta unívoca. Trata-se, pois, de um mecanismo utilizado pelo intérprete. Assim, Moro entendeu que a noção de ilicitude como um predicado do crime, representou avanço técnico, fazendo-se manter a unidade do crime. $^{38}$ Em outras palavras, não haveria que se falar em separação ou ligação entre elementos do crime.

Segundo entendeu Rocco, na concepção verdadeiramente unitária de crime, a ilicitude é uma característica que envolve todo o conceito, sendo a essência do crime. ${ }^{39}$ Sendo o crime a violação à norma penal, a ilicitude representa a exata contradição a ela. Justamente nessa relação de contradição é que se encontra a ilicitude, um juízo sobre fato praticado, que é contrário ao direito. ${ }^{40}$

\footnotetext{
${ }^{35}$ PAGLIARO, Antonio. op. cit., v. 2, p. 61.

${ }^{36}$ Id., loc. cit.

${ }^{37}$ MAGGIORE, Giuseppe. op. cit., v. 1, p. 255.

${ }^{38}$ MORO, Aldo. op. cit., p. 191.

${ }^{39}$ Moro faz referência a esta afirmação de Rocco, que entendia a antijuridicidade como um predicado da relação, que surge da contradição entre a ação humana e o preceito moral. Era o "em si" do crime (ROCCO. Oggeto del reato, p. 468 y ss. Apud: MORO, Aldo. op. cit., p. 9).

Antolisei também conceitua assim a antijuridicidade, mesmo não adotando a teoria unitária: "non è, come ritiene una larga corrente dottrinaria, un componente, vale a dire, un elemento costitutivo dell'illecito. Essa è molto di piu: è come fu rilevato dal Rocco con felice espressione, la essenza stessa, la natura intrínseca, l'in se del reato'." (ANTOLISEI, Francesco. op. cit., p. 192). Certo é que este conceito de ilicitude, entendido como essência do crime, teve certa aceitação também entre autores filiados a outras concepções (bipartição, tripartição etc.).

Delitala, igualmente não adotando o conceito unitário de crime, distingue os conceitos de antijuridicidade penal (que se liga à punibilidade do fato: ação culpável) e de antijuridicidade geral (também denominada objetiva: relação de contradição entre o fato e a norma, prescindindo da culpabilidade). $\mathrm{O}$ autor afirma que somente esta última (antijuridicidade geral) pode ser considerada elemento do crime. Aquela primeira (antijuridicidade penal) é mais: trata-se da própria qualidade de proibição do crime como um todo. (DELITALA, Giacomo. El “hecho" em la teoria general del delito. Buenos Aires: B de F, 2009. p. 69. (Maestros del derecho penal, 29).

${ }^{40}$ Conforme Antolisei, o delito consiste na violação de um preceito do ordenamento jurídico-penal. Sua nota fundamental é o contraste com o direito. E é exatamente neste contraste que se verifica a antijuridicidade. (ANTOLISEI, Francesco. op. cit., p. 192).
} 
Entretanto, é de se considerar que a adoção da teoria unitária representa a obtenção de resultado similar ao conseguido pela adoção da teoria dos elementos negativos do tipo. ${ }^{41}$ Em suma, a exclusão da ilicitude, nesta concepção, leva à desconsideração de todo o fato por causa da unidade do conceito de delito. ${ }^{42}$

\subsection{O conceito bipartido de delito e a relação entre tipo penal e ilicitude}

A noção bipartida do delito teve importante destaque na doutrina italiana e diferentes fundamentações teóricas na busca por melhor estudar e compreender este conceito.

Neste sentido, Bettiol já dizia que a rejeição a uma concepção unitária de delito não significava banir conceitos naturalísticos do direito penal, e esclarecia que eram exageradas as afirmações de Wolf, visto que defendia que cada elemento do crime teria caráter normativo em virtude da transformação da realidade ao ser confrontada com as normas. ${ }^{43}$ Criticou, ainda, os positivistas, que analisavam o delito meramente sob o aspecto naturalístico (sob a óptica extrajurídica) e concluiu que o melhor caminho a ser trilhado é o de que os elementos normativos não poderiam desaparecer por completo do direito penal justamente porque o crime se mostra um fenômeno do mundo natural e o fato que o constitui é resultado da vontade humana. ${ }^{44}$

Carrara foi um autor que se valeu da concepção bipartida de crime e afirmava não ser correto falar-se em atribuição de responsabilidade por um resultado naturalístico sem que também se pudesse lhe atribuir a causa moral do fato. ${ }^{45}$ Dizia que a conduta atribuída a alguém deveria ser, ainda, reprovável. ${ }^{46}$ Desta forma, a divisão entre as partes objetiva e subjetiva, em Carrara, mostrava-se evidente de modo que as forças físicas ${ }^{47}$ e morais ${ }^{48}$

\footnotetext{
${ }^{41}$ MORO, Aldo. op. cit., p. 191-192. Moro, antes de emitir sua opinião, descreve as formas de ligação entre o tipo e a ilicitude, desde o conceito típico de Beling, até a da ratio essendi (MORO, Aldo. op. cit., p. 181 e ss.).

${ }^{42}$ Id. Ibid., p. 191-192.

${ }^{43}$ BETTIOL, Giuseppe. op. cit., v. 1, p. 223-224.

${ }^{44}$ Id., loc. cit.

${ }^{45}$ CARRARA, Francesco. Programa del curso de derecho penal: parte general. Traducción de la 11. ed. italiana por Sebastin Soler con la colaboración de Ernesto Gavier y Ricardo Nuñez. Buenos Aires: Depalma, 1944. v. 6, p. 35-36.

${ }^{46}$ Id., loc. cit.

${ }^{47}$ É o movimento corporal para a realização de um determinado desígnio, havendo, por isso, a ofensa a um direito.

${ }^{48}$ É a vontade humana que executa a conduta.
} 
deveriam reunir-se para que se pudesse censurar alguém pela prática delitiva. ${ }^{49}$ E é o somatório das forças física e moral que forma o elemento político do crime, afastando-o de relações puramente morais e religiosas, devendo o delito ter resultado politicamente danoso (dano a interesse social). ${ }^{50}$

Manzini tem entendimento semelhante, conceituando delito com elementos materiais e morais, embora seja mais claro sobre a ilicitude no conceito de crime. Para o autor, elementos materiais são compostos pela conduta e por elementos que determinam a conduta e o que leva à produção do resultado. ${ }^{51}$ Os elementos morais são compostos pelo dolo e pela culpa, ou, ainda, por finalidades específicas. ${ }^{52}$ Sua abordagem, no entanto, parece ser mais clara quanto à ilicitude. Trata dela como implícita, salvo quando verificáveis situações excepcionais. ${ }^{53}$ A ilicitude, para o autor, é conceito objetivo e que independe do dolo e da culpa e, mais do que isso, a entende como característica do fato, não um elemento do crime, portanto uma violação da norma em um aspecto formal. ${ }^{54}$ Desta forma, a verificação material do crime será algo como uma consequência.

Além de Carrara e Manzini, Antolisei também foi adepto da teoria bipartida, com entendimento semelhante ao dos supracitados. Assim, define o crime com uso de elementos objetivos e subjetivos, sendo o primeiro deles o fato material e o segundo a vontade culpável. ${ }^{55}$ Para o autor, fato material é a composição feita a partir do comportamento humano, do resultado, da relação de causalidade entre a conduta e o resultado, além da inexistência de causas de justificação. ${ }^{56}$

O entendimento de Antolisei afasta-se das concepções de Beling e Delitala, sendo o tipo penal composto por um complexo conjunto de elementos objetivos e subjetivos, não havendo nesse conceito apenas elementos materiais. ${ }^{57}$ Nesse sentido, considera a ilicitude

\footnotetext{
${ }^{49}$ A força moral é subdividida por Carrara em aspectos subjetivo (vontade) e objetivo (intimidação que o delito provoca). Para o autor também há, no conceito de força moral, a consciência (conhecimento da lei, que pode ser potencial) e vontade (liberdade de atuação). Assim, dolo (normativo) e culpa integram o crime. CARRARA, Francesco. op. cit., p. 67-68 e 80.

${ }^{50}$ Id. Ibid., p. 36.

${ }^{51}$ MANZINI, Vicenzo. Trattato di diritto penale italiano, cit., v. 1, p. 564.

${ }^{52}$ Id. Ibid., p. 565.

${ }^{53}$ Id. Ibid., p. 542.

${ }^{54}$ Id. Ibid., p. 540-541.

${ }^{55}$ ANTOLISEI, Francesco. op. cit., p. 212. Ademais, conceitua a culpabilidade em uma teoria psicológiconormativa, isto é, em concepção de que representa a contradição entre a vontade do sujeito e a norma. E, dessa forma, delimita o conteúdo subjetivo do delito, concluindo que o dolo e a culpa de per si não implicam na imputabilidade, de modo que esta não pode ser considerada como pressuposto da culpabilidade, mas um verdadeiro modo de se analisar o acusado.

${ }^{56}$ ANTOLISEI, Francesco. op. cit., p. 215-216.

${ }^{57}$ Id. Ibid., p. 197-198.
} 
como essência do delito, representando mais que um seu elemento. ${ }^{58}$ Trata-se, pois, da relação de contradição entre o fato e as normas jurídicas, estando tanto o fato quanto a culpabilidade no mundo natural, sendo a ilicitude um juízo de valor responsável por determinar a mencionada relação de contrariedade. ${ }^{59}$

Para Antolisei, ao analisar-se a ilicitude, em primeiro lugar se determina a figura do tipo, como uma condição positiva e, depois, não se verificando causas de justificação, como condição negativa. ${ }^{60}$ Essa vinculação da ilicitude com a tipicidade aproxima seus estudos da doutrina do tipo total do injusto, surgida na Alemanha de modo que, ainda que se valendo de argumentos outros, chega a conclusões parelhas com a doutrina germânica, em especial quanto às causas de justificação. ${ }^{61}$

Por outro lado, Gallo também parece aderir à teoria bipartida ao adotar um conceito de tipo mais amplo, abarcando elementos objetivos e subjetivos que compõem os efeitos do delito. Apesar disso, não nega as vantagens verificadas pelo uso de um conceito mais restrito de tipo penal e, embora assim reconheça, afirma que a construção mais restrita só poderia ser aceita caso englobasse as causas de justificação. ${ }^{62}$

Também é de se frisar que o entendimento de Antolisei diverge daquele de Pagliaro, para o qual a decomposição analítica do delito se verifica nas teorias do fato puro e, ainda, na imputação do fato a alguém. Assim, fato é uma ocorrência com consequências jurídicas, representando um conceito da Teoria Geral do Direito, todavia aplicado ao Direito Penal. ${ }^{63}$ Já se disse que para este autor o ponto fulcral do delito é o fato delitivo, contanto que seja atribuído à pessoa determinada, isto é, alguém que seja objeto de análise e imputação. ${ }^{64}$ Existe, assim, segundo seus estudos, duas teorias: a do fato e a do réu. Nesta primeira (teoria do fato), estão os elementos objetivos e também os subjetivos da conduta, e na parte objetiva verificam-se a ação ou omissão e o nexo causal. ${ }^{65}$ Quanto à parte subjetiva, há o dolo e a culpa. Já a teoria do réu, parte essencial à existência da outra, a do

\footnotetext{
${ }^{58}$ ANTOLISEI, Francesco. op. cit., p. 198.

${ }^{59}$ Id. Ibid., p. 209.

${ }^{60}$ Id. Ibid., p. 195.

${ }^{61}$ GALLO, Marcello. Premésse alla teoria della colpevolezza. Rivista Italiana di Diritto e Procedura Penale, Milano, fasc. 2, p. 395, 1949.

${ }^{62}$ Id., loc. cit.

${ }^{63}$ PAGLIARO, Antonio. op. cit., v. 2, p. 62-63.

${ }^{64}$ REALE JÚNIOR, Miguel. Teoria do delito, cit., p. 55.

${ }^{65}$ PAGLIARO, Antonio. op. cit., v. 2, p. 155 e ss.
} 
fato, é o lugar onde são verificados os critérios que permitem a atribuição de responsabilidade penal a alguém. ${ }^{66}$

Com base nestas observações pode-se entender que Pagliaro não admite a separação entre a avaliação da conduta (reprovação) e a consciência e vontade da realização dela, isto é, existe uma necessária relação entre a parte objetiva e a subjetiva. ${ }^{67}$ E, com isso, é válido o questionamento sobre a função culpabilidade na teoria bipartida, que não significa um conceito dogmático penal, mas uma espécie de princípio geral proibindo que os incapazes de entender e se determinar conforme esse entendimento sejam alvo de sanção penal. É o que assevera Miguel Reale Júnior. ${ }^{68}$

Pagliaro menciona a formação de duas teorias quanto à culpabilidade: a psicológica e a normativa, e defende a ideia de que a culpabilidade busca fornecer caráter diferenciado aos elementos subjetivos (dolo e culpa), em suma, rechaçando a ideia do conceito unicamente relacionado aos inimputáveis, tendo-se em vista a antiga ideia de ética e responsabilidade moral pelo fato. ${ }^{69}$ Miguel Reale Júnior discorda dessa concepção, alegando que a inexigibilidade e a possibilidade de se conhecer a ilicitude são componentes a serem analisados sob a óptica da reprovabilidade da ação, de modo a congregarem o dolo e a culpa num conceito único de culpabilidade. ${ }^{70}$

Fato é que a ilicitude, para Pagliaro, é elemento essencial do crime, representando a contrariedade do fato com o Direito, implicitamente verificado na conduta, adjetivada como ilícita. O autor adota teoria que lembra a dos elementos negativos do tipo, especialmente porque reconhece elementos negativos da conduta e entende que estes devem estar ausentes para que o fato seja considerado ilícito. E, assim, entende que há dois grupos de causas que impedem a configuração do crime. O primeiro grupo é composto pelas excludentes do elemento subjetivo do delito e vincula-se à consciência, vontade, dolo e culpa, como são os casos da força maior, do caso fortuito, erro de fato, delito putativo, entre outros. ${ }^{71}$ Já o segundo grupo é composto pelos elementos negativos do tipo, que quando contrapostos à conduta, criam imediatamente um novo conceito: o dos elementos negativos da conduta ilícita. Nessa concepção, é possível distinguir os elementos positivos

\footnotetext{
${ }^{66}$ PAGLIARO, Antonio. op. cit., v. 2, p. 62.

${ }^{67}$ Id. Ibid., p. 155 e ss.

${ }^{68}$ REALE JÚNIOR, Miguel. op. cit., p. 56.

${ }^{69}$ PAGLIARO, Antonio. op. cit., v. 2, p. 134.

${ }^{70}$ REALE JÚNIOR, Miguel. op. cit., p. 56.

${ }^{71}$ RAMACCI, Fabrizio. Istituzioni di diritto penale. Corredato di nota di aggiornamento. Torino: G. Giappichelli, 1988. p. 207. Tais institutos encontram-se nos arts. 45 a 49 do Código Penal Italiano.
} 
e os negativos, cujas presenças respectivamente fazem existir o delito ou deixar de existir. Isso faz com que as causas de justificação pertençam ao elemento objetivo, e, consequentemente, a presença da justificação na conduta do agente exclui a ação típica. ${ }^{72}$

A doutrina italiana denomina de elementos negativos da conduta ilícita justamente a correlação entre o fato considerado como (i)lícito e os elementos constitutivos do tipo permissivo, que fazem excluir a norma proibitiva, justificando a conduta. Concluem, Pagliaro e Tranchina, que a exclusão do crime a partir da verificação dos elementos negativos da conduta ilícita se dá pelo desejo estatal em tutelar um determinado interesse em conflito. ${ }^{73}$ Por seu turno, Ramacci assevera que a justificativa se dá porquanto não há dano social na conduta do agente. ${ }^{74}$

Já Miguel Reale Júnior apresenta teoria bipartida de Pannain, num conceito próximo ao de Antolisei, em que o crime se divide em fato e elemento subjetivo. $\mathrm{O}$ primeiro representa os elementos materiais e subjetivos. ${ }^{75}$ Assim, esclarece que Mezger compreendia o fundamento da ilicitude como sendo a própria lei, de modo que o legislador proíbe certas ações mediante a imposição de sanções. Segue dizendo que Binding e Mezger consideram a ilicitude violação da norma, e a punibilidade, a sanção a esta violação, o que faz com que o tipo constitua não apenas a ratio cognoscendi da norma, mas sua ratio essendi. Desta forma, a ilicitude não integra a tipicidade, mas o crime, uma vez que poderá haver condutas típicas, não antijurídicas em razão das causas de exclusão. ${ }^{76}$

Miguel Reale Júnior, entendendo ser a ilicitude uma constatação da tipicidade pela ausência de causas de justificação, esclarece que só é típico o que for lesivo de um valor por não se realizar a ação autorizada numa causa de justificação. ${ }^{77}$ Acrescenta que, a exemplo de Pagliaro, defende que os tipos penais impõem a inexistência das causas de justificação. Assim, "se pretendesse dar uma autonomia à antijuridicidade, seria forçoso concluir que constitui antijuridicidade a ausência daquilo que se existisse ela deixaria de existir, em uma demonstração de que não tem a antijuridicidade autonomia, mas constitui outra face da tipicidade". Conclui, então, que o delito se compõe de ação típica em suas faces positiva e negativa, além da culpabilidade, não se impedindo que esse

\footnotetext{
${ }^{72}$ Tal como sustentou Merkel, na doutrina jurídico-penal alemã.

${ }^{73}$ PAGLIARO, Antonio; TRANCHINA, Giovanni. Istituzioni di diritto e procedura penale. Milano: Giuffrè, 2000. p. 117.

${ }^{74}$ RAMACCI, Fabrizio. op. cit., p. 184.

${ }^{75}$ REALE JÚNIOR, Miguel. op. cit., p. 54.

${ }^{76}$ Id. Miguel. Instituições de direito penal: parte geral. 3. ed. Rio de Janeiro: Forense, 2009. p. 138.

${ }^{77}$ Id. Ibid., p. 145. Acrescenta que concorda com Gallo quanto ao entendimento de que as descriminantes são elementos negativos do tipo.
} 
posicionamento prejuízo quanto ao exame da face negativa da tipicidade em separado, diante das causas de exclusão de tipicidade, sob a nomenclatura de antijuridicidade. ${ }^{78}$

Silva Sánchez, lembrando que desde a época de Lizst e Beling na Alemanha domina a noção de delito sob uma concepção tripartida, defende a ideia da bipartição. ${ }^{79}$

Em suma, pode-se apontar que mesmo quanto ao conceito analítico bipartido do crime não se verifica consenso, pelo contrário, há diversas vertentes, como se observou acima. Nota-se, assim, que há vertentes que deixam de relacionar expressamente a relação entre o tipo penal e a ilicitude (Carrara e Manzini) e, ainda, outras, que se aproximam com a teoria do tipo total do injusto, que idealiza a exclusão do fato típico pelas causas de justificação, sendo estas seus elementos negativos.

\subsection{O conceito tripartido de delito e a relação entre tipicidade e ilicitude}

Diz-se que coube a Delitala, depois de Rocco, sistematizar a concepção tripartida do delito na Itália, esclarecendo que houve muita resistência pelos juristas e pelos tribunais daquele país para que aceitassem essa teoria. ${ }^{80}$ Segundo Delitala, o delito é um fato humano, ilícito e culpável. ${ }^{81}$

Este autor entendia que o fato deve subsumir-se aos limites do tipo penal para que haja tipicidade, numa necessidade de exercício de garantias ao cidadão. Ademais, esclarece que há característica naturalística na definição do fato, verificada na concretude do fato hipotético tipificado na lei. Dessa forma, o estudo do fato deve ser limitado à análise dos elementos objetivos necessário para fazer surgir o delito, mas que não seria isso suficiente sem que houvesse os juízos de ilicitude e culpabilidade. ${ }^{82}$

Nota-se orientação causalista no autor, que apresenta distinções entre a tipicidade objetiva e subjetiva, propondo uma divisão entre os elementos materiais e psíquicos do delito. ${ }^{83}$ Mas quanto ao aspecto subjetivo, esclarece que rechaçado o conceito de tipicidade

\footnotetext{
${ }^{78}$ REALE JÚNIOR, Miguel. Instituições de direito penal: parte geral, cit., p. 145.

${ }^{79}$ SILVA SÁNCHEZ, Jesus-Maria. Aproximación al derecho penal contemporáneo. Buenos Aires; Montevidéu: B de F, 2010. p. 606 e ss.

${ }^{80}$ DALBORA, José Luis Guzman. Prólogo à obra de DELITALA, Giacomo. El “hecho” em la teoria general del delito, cit., p. 17. No mesmo sentido, BETTIOL, Giuseppe. op. cit., v. 1, p. 227.

${ }^{81}$ DELITALA, Giacomo. op. cit., p. 55.

${ }^{82}$ Id., loc. cit.

${ }^{83}$ Id. Ibid., p. 139.
} 
subjetiva, a doutrina alemã entende estar incluídos no conceito de fato os elementos materiais imputáveis ao agente, isto é, a ação delitiva com todas as condições que a caracterizam e que variam conforme a prática do diversos delitos. Então, quanto ao rechaço do conceito subjetivo, concorda com Beling. ${ }^{84}$

Delitala definia a ilicitude como sendo a negação do Direito, resultando na contradição do fato com o Direito objetivo, portanto, não havia diretamente ligação ao Direito subjetivo. ${ }^{85}$ Entende, enfim, que toda violação objetiva importa na violação subjetiva de forma imediata. ${ }^{86}$ A existência da ilicitude está intimamente relacionada com a culpabilidade. Em outras palavras, pode-se falar de ações e fatos ilícitos sem que haja culpabilidade diante de simples constatação de conformidade objetiva entre o fato concreto e o modelo tipificado na lei. ${ }^{87}$

Delitala e Bettiol entendem que a solução para esta questão conceitual resplandece na interpretação que se faz da função da norma, isto é, compreendendo-a como valorativa e imperativa, portanto de natureza mista. Isto autoriza a valoração como proibidas as condutas dos inimputáveis, mesmo que a elas não possa ser imposta a determinação imperativa da norma. ${ }^{88}$

Assim, diferencia-se a ilicitude penal da ilicitude objetiva, de forma que aquela, como elemento do crime, deve ser verificada de forma autônoma em relação à imputabilidade e a culpabilidade. ${ }^{89}$ Diz que é ilícito o comportamento que, objetivamente considerado, contrasta com os fins do ordenamento jurídico, com o ideal de valoração dos fatos.

O autor relaciona a ilicitude com a tipicidade, primeiro afastando a possibilidade de conceituação única para ambos. ${ }^{90}$ No mesmo sentido pensa Padovani, que asseverou ser facilmente verificável a ilicitude objetiva pela ausência de causas de justificação, sendo essencial que se mantenha sua análise de forma autônoma, não representando elemento negativo do tipo. ${ }^{91}$

\footnotetext{
${ }^{84}$ DELITALA, Giacomo. op. cit., p. 145. Nesse particular, afasta-se do entendimento de Mayer.

${ }^{85}$ Id. Ibid., p. 58.

${ }^{86}$ Id., loc. cit.

${ }^{87}$ Id. Ibid., p. 59.

${ }^{88}$ Id. Ibid., p. 67-68. BETTIOL, Giuseppe. op. cit., v. 1, p. 95.

${ }^{89}$ DELITALA, Giacomo. op. cit., p. 66-67.

${ }^{90}$ Id. Ibid., p. 77.

${ }^{91}$ PADOVANI, Tullio. Alle radici di un dogma: appunti sulle origini dell'antigiuridicità oggettiva. Rivista Italiana di Diritto e Procedura Penale, Milano, nuova serie, anno 26, p. 551, 1983.
} 
Delitala também afasta os elementos normativos e subjetivos do fato, definindo a ilicitude objetivamente considerada com valoração própria, afirmando que ela prescinde da culpabilidade e não pode ser considerada um elemento ou condição do fato. Assim, o fato não pode ser compreendido como ilícito. ${ }^{92}$

Por outro lado, é possível dizer que Delitala adotou a mesma concepção de Beling, no sentido de uma separação total entre o tipo objetivo e a ilicitude, ao passo que entende que a separação do fato e ilicitude ou se dá em todos os casos ou não será permitido em nenhum. ${ }^{93} \mathrm{O}$ tipo penal, para este autor, é objetivo e independente da ilicitude e não aceita que a tipicidade represente um caráter indiciário da ilicitude, alegando que o fato se mostra lícito ou ilícito a depender das circunstâncias em que foi praticado. ${ }^{94}$

Bettiol utiliza a estrutura tripartida do crime por entender que a unidade do conceito existe apenas no plano naturalístico, frisando que os motivos que levam à decomposição analítica do crime são de ordem lógica, sendo elementos do delito o fato típico, a ilicitude e a culpabilidade. ${ }^{95}$ Para ele o fato deve ser analisado objetivamente, sendo seus elementos a conduta, o resultado e o nexo causal e, ainda, existindo elementos normativos no tipo que demandam valoração específica, relacionados com a técnica legislativa e política. ${ }^{96}$

A ilicitude tem destaque no conceito do crime, representando a contrariedade entre fato e norma, isto é, a valoração feita quanto à lesividade da conduta humana. ${ }^{97}$ Portanto, Bettiol entende que a relação entre tipo penal e ilicitude é definida por uma hipótese de regra e exceção, e o tipo penal teria a função indiciária da ilicitude, exceto quando houver alguma causa de justificação. ${ }^{98}$ Nega, portanto, a ratio essendi, adotando-se a ratio cognoscendi.

Maggiore é outro que adotou a concepção tripartida, defendendo um conceito formal e objetivo de tipo penal, sendo composto pela conduta, pelo nexo de causalidade e pelo resultado, deixando para a culpabilidade a análise subjetiva do delito. ${ }^{99}$ Assim,

\footnotetext{
${ }^{92}$ DELITALA, Giacomo. op. cit., p. 77.

${ }^{93}$ Id. Ibid., p. 149.

${ }^{94}$ GUZMAN DALBORA, José Luis. Prólogo. In: DELITALA, Giacomo. El “hecho” em la teoria general del delito, cit., p. 29-30.

${ }^{95}$ BETTIOL, Giuseppe. op. cit., v. 1, p. 236.

${ }^{96}$ Id. Ibid., p. 256 e ss.

${ }^{97}$ Id. Ibid., p. 318.

${ }^{98}$ Id. Ibid., p. 229.

${ }^{99}$ MAGGIORE, Giuseppe. op. cit., v. 1, p. 309 e ss.
} 
entende culpável a pessoa que tem condições pessoais de conhecer e respeitar a norma e, ainda assim, a transgride consciente e voluntariamente. ${ }^{100}$

Com referência à ilicitude, Maggiore a entendia não como um elemento, mas como um aspecto do crime, vislumbrando-a como conceito objetivo, mas cuja consciência é subjetiva. ${ }^{101}$ Apesar de tal posicionamento, não mencionou expressamente seu entendimento quanto à relação da ilicitude e o tipo penal, embora pela leitura de sua obra se tenha a impressão de que adotou a teoria da ratio cognoscendi, teoria essa que vem expressa na obra de Fiandaca e Musco. ${ }^{102}$

Fiandaca e Musco partem da concepção analítica tripartida - tipo, ilicitude e culpabilidade - para afirmar que o fato, presumidamente ilícito, poder restar justificado diante de sua análise em face da totalidade do ordenamento. ${ }^{103}$ No entendimento desses autores a ilicitude se mostra presente na confirmação do caráter ilícito do fato, o que faz determinar o âmbito de proteção da norma. ${ }^{104}$ Asseveram que o juízo de ilicitude se resolve naturalmente ao se verificar a inexistência de causas de justificação. Por outro lado, a presença de uma dessas causas anula a ilicitude de uma conduta incialmente típica. ${ }^{105}$

Também é de se frisar que para Fiandaca e Musco o fato é um conjunto de elementos (objetivos e subjetivos), cuja função é a proteção de bens jurídicos, tendo a ilicitude um caráter objetivo e sendo conceito distinto da culpabilidade. ${ }^{106}$ Também entendem que o dolo e a culpa são elementos do tipo e da culpabilidade, e esta, num conceito normativo se presta a resolver melhor as questões do liame subjetivo e da reprovação da norma em relação à conduta praticada. ${ }^{107}$

Feitos os comentários acima, é de se apontar que a teoria da ratio cognoscendi é majoritária nas concepções tripartidas. Quanto a isso se manifestou Schiaffo sustentando que nos posicionamentos prevalentes na doutrina italiana, a ilicitude representa uma categoria autônoma na estrutura do crime, sendo útil para o arranjo das causas de

\footnotetext{
${ }^{100}$ MAGGIORE, Giuseppe. op. cit., v. 1, p. 447.

${ }^{101}$ Id. Ibid., p. 385.

${ }^{102}$ FIANDACA, Giovanni; MUSCO, Enzo. Diritto penale: parte generale, cit., p. 181.

${ }^{103}$ Visão essa que se assemelha com a teoria da tipicidade conglobante delineada por Zaffaroni e acima exposta.

${ }^{104}$ FIANDACA, Giovanni; MUSCO, Enzo. op. cit., p. 181.

${ }^{105}$ Id. Ibid., p. 182.

${ }^{106}$ Id. Ibid., p. 180.

${ }^{107}$ Id. Ibid., p. 346.
} 
justificação. ${ }^{108}$ Assim, a noção tripartida de delito alcançou importante aceitação entre os doutrinadores italianos, passando pelos estudos de Delitala até Schiaffo, que a admitem. ${ }^{109}$

Não se pode deixar de mencionar, entretanto, a concepção de Bataglini, que coloca a punibilidade em seu conceito tripartido de modo que o delito seria formado pelos seguintes elementos: fato, culpabilidade e punibilidade. ${ }^{110}$ Esta posição foi criticada por Bettiol, que afirmou ser um equívoco metodológico a alocação da punibilidade entre os elementos do delito, devendo ela ter sido deixada como consequência. ${ }^{111}$

Pagliaro adverte, todavia, que parece precipitado sustentar que esta tripartição seja a forma de conceituação mais difundida na atualidade do ordenamento jurídico-penal italiano. ${ }^{112}$ Lá, a doutrina ainda é muito fragmentada nesse sentido. De toda forma, independentemente de ser a doutrina mais difundida na Itália, pode-se claramente deduzir que a concepção tripartida sustenta a autonomia da ilicitude e, predominantemente, também adota a ideia da regra-exceção, aos moldes da ratio cognoscendi. Contudo, parece não haver preocupação destacada quanto ao estudo das relações entre o tipo e a ilicitude na Itália, ao menos entre os autores aqui mencionados, em suas obras pesquisadas. ${ }^{113}$

Frise-se, ademais, que o surgimento da concepção tripartida do delito se prestou a aproximar as doutrinas italianas e alemãs, ainda que de forma tímida. Neste particular vale apontar o pensamento de Jescheck e Weigend, que discorrem sobre a formação de um conceito de delito, informando que os elementos não permanecem desconectados, pelo contrário, eles mantêm uma relação interna de organização tópica e sistemática, mas, devido ao constante surgimento de novas ponderações quanto a velhos problemas,

\footnotetext{
${ }^{108}$ SCHIAFFO, Francesco. Riflessioni critiche intorno ad un dogma: l'antigiuridicità genérica. Rivista Italiana di Diritto e Procedura Penale, Milano, anno 42, fasc. 3, p. 1075, lugl./sett. 1999.

${ }^{109}$ FIANDACA, Giovanni; MUSCO, Enzo. op. cit., p. 175. Vide, ainda, SCHIAFFO, Francesco. op. cit., p. 1075.

${ }^{110}$ BATAGLINI, Giulio. Diritto penale: parte generale. Padova: Cedam, 1949. p. 109.

${ }^{111}$ Id., loc. cit.

${ }^{112}$ PAGLIARO, Antonio. Trattato di diritto penale: il reato, cit., v. 2, p. 43.

Fiandaca e Musco, por exemplo, afirmam que: "Ancor ché a nostro avviso piu idônea ad essere utilizzata anche nella prassi applicativa, la concezione tripartida non è fino rari uscita ad affermar si nell'ambito della giurisprudenza italiana: la quale, purrimanendo tendezialmente legata al modello naturalístico della contrapposizione elemento oggetivo ' - elemento soggetivo', continua a mantenere sul terreno della teoria generale del reato atteggiamenti ambigui.” (FIANDACA, Giovanni; MUSCO, Enzo. op. cit., p. 177).

${ }^{113}$ Veja-se, nesse sentido, a opinião de Gallo: "I rapporti trafatto e antigiuridicità sono stati, come è noto, oggetto di tormentose discussioni da parte della dottrina tedesca. Senon chè, ad um esame approfondito il contrasto non tarda a rilevarsi puramente terminologico. Nessuna reale importanza há infatti concepire le due nozione come del tutto distinte, o considerare la prima base di conoscenza o addirittura ratio essendi della seconda, se poi concordemente si affermiche, in ogni modo, un comportamento umano deve dirsiantigiuridico quando, conforme alla fatti specie nel ristretto significato che a tale nozione è attribuito dagli scrittori tedeschi, manchidi cause di giustificazione: se, in altre termini, non si revochi in dubbio la natura oggetiva dell'antigiuridicità.” (GALLO, Marcello. Premésse alla teoria della colpevolezza, cit., p. 411).
} 
adquirem contornos distintos com o tempo, de modo que a concepção do conceito de delito jamais resta finalizada. ${ }^{114}$

Também na visão de Jescheck e Weigend, a concepção tripartida manteve-se mais constante quanto ao entendimento de conceito analítico de delito, entendendo-se que o mesmo é composto pela tipicidade, ilicitude e culpabilidade. ${ }^{115}$ Tais autores informam que coube a Ihering, em 1867, desenvolver o conceito de ilicitude objetiva no âmbito do direito civil com vistas a demonstrar que a culpabilidade não oferecia qualquer resultado prático em certos casos. ${ }^{116}$ Prosseguem dizendo que, no entanto, foram Liszt e Beling que efetivamente trouxeram o conceito de culpabilidade objetiva para o direito penal e que Binding, apesar de não ter se dado conta do avanço sistemático deste passo, pela aplicação da sua teoria das normas, promoveu caráter autônomo à ilicitude. ${ }^{117}$ Ressaltam de início, que um conceito de culpabilidade singularmente considerado e que remonta aos estudos de Merkel, baseando-se na teoria da imputação, uniu o dolo e a culpa sob o conceito da superior determinação volitiva contrária a um dever. ${ }^{118}$

Também afirma-se que teria sido Berner o responsável por atribuir destaque ao conceito de ação na construção científica do delito, e que por último foi formulado teoricamente o conceito de tipicidade da ação punível. ${ }^{119} \mathrm{E}$, de acordo com Beling, "a tipicidade ou adequação ao tipo como qualidade da ação se converte em um elemento conceitual do delito", de modo que, desta forma, o tipo alcançou posição dominante na estrutura do delito como ponto de referência para o juízo de ilicitude e culpabilidade. Foi assim, então, que Beling, no início do século passado, desenvolveu o conceito de delito nos seguintes termos: "o delito é a ação típica, antijurídica e culpável, submetida a uma cominação penal adequada e sujeita às condições desta". ${ }^{120}$

Isso demonstra o entendimento de uma concepção quadripartida de delito, e deve-se mencionar que há outros autores que se valem deste entendimento, como é o caso de Marinucci e Dolcini que defendiam a tese de que o crime era composto pelo fato, pela

\footnotetext{
${ }^{114}$ JESCHECK, Hans-Heinrich; WEIGEND, Thomas. Tratado de derecho penal: parte general. 5. ed. Traducción de Miguel Olmedo Cardenete. Granada: Comares, 2002. p. 213.

${ }^{115}$ Id. Ibid., p. 214.

${ }^{116}$ Id. Ibid., p. 215-216.

${ }^{117}$ Id. Ibid., p. 216.

${ }^{118} \mathrm{Id}$., loc. cit.

${ }^{119}$ Id., loc. cit.

${ }^{120}$ BELING, Ernst Von. Die Lehre vom Verbrechen, p. 178 e ss. apud JESCHECK, Hans-Heinrich; WEIGEND, Thomas. op. cit., p. 217.
} 
ilicitude, pela culpabilidade e, ainda, pela punibilidade. ${ }^{121}$ A teoria quadripartida é, pois, semelhante à tripartida, acrescendo-lhe um elemento: a punibilidade, não havendo diferenças quanto à concepção de ilicitude.

Quanto à teoria tripartida e sua aceitação na Alemanha, Roxin esclarece que há praticamente um consenso doutrinário quanto à composição do delito. Este seria formado por uma ação típica, antijurídica, culpável, comportando, ainda, outros elementos (pressupostos de punibilidade). ${ }^{122}$ Tal entendimento, já mencionado como o adotado por Jescheck e Weigend, é também aquele defendido por Jakobs, que deixa claro sua opção pela vertente tripartida ao mencionar a realização do tipo como fase da imputação, especialmente quando afirma que a pena pressupõe "o agir penalmente típico, antijurídico e culpável". ${ }^{123}$

\subsection{Observações finais à guisa de uma conclusão}

Não se discute que as relações entre a tipicidade e a ilicitude, elementos de um conceito analítico de delito, historicamente passaram por distintas concepções. Mesmo porque atualmente persistem opiniões em sentidos diversos.

Pela análise das diversas facetas da teoria do delito percebe-se que se pretendeu uma organização teórica que estabelecesse os requisitos que uma conduta deveria contar para que fosse considerada delitiva e, assim, pudesse receber a sanção penal. Diz-se de uma organização teórica porque foi construída em nível de abstração distinto da lei e de sua aplicação prática.

Assim, diz-se que a teoria do delito é uma teoria de imputação que se ocupa de atribuir culpa e mérito aos que cumprem e descumprem as responsabilidades advindas da convivência social. ${ }^{124} \mathrm{E}$, para que haja imputação, é preciso deixar cristalino o que as pessoas podem fazer na sociedade, de modo que seja possível estudar as consequências do

\footnotetext{
${ }^{121}$ MARINUCCI, Giorgio; DOLCINI, Emilio. Manuale di diritto penale: parte generale, cit., p. 139.

${ }^{122}$ ROXIN, Claus. Derecho penal: parte general. 2. ed., cit., t. 1, p. 194.

${ }^{123}$ JAKOBS, Günther. Derecho penal: parte general: fundamentos y teoría de la imputación. Traducción: Joaquim Cuello Contreras; José Luis Serrano Gonzales de Murillo. Madrid: Marcial Pons, 1997. p. 188.

${ }^{124}$ RAZ, Joseph. Razón práctica y normas. Trad. Juan Ruiz Manero. Madrid: Centro de Estudios Constitucionales, 1999. p. 14. (Colección El Derecho y la Justicia).
} 
descumprimento das exigências legais. ${ }^{125} \mathrm{E}$ isso passa, necessariamente, por ponderação de valores ante situações mais ou menos desejáveis.

Neste sentido, a teoria do delito deveria ser construída fundando-se em leis penais que anunciassem normas dirigidas aos cidadãos (mandatos e proibições) e ao juiz (relativas à aplicação da lei). ${ }^{126}$ De fato, esta teoria vem se reconstruindo continuamente sobre a base de um sistema de valores em que se deveria ponderar a racionalidade e legitimidade material para todo o sistema, cumprindo funções sistemáticas, estruturais, interpretativas etc.

A existência de normas primárias e de bens jurídicos protegidos decorre de um esquema teórico e que deveria dotar o sistema de uma racionalidade. Nesta perspectiva, valor, norma e imputação são distintos momentos do conceito jurídico de delito, sendo e os primeiros - valor e norma - se inter-relacionam de forma implícita. ${ }^{127}$ Afirma-se, assim, que a distinção entre o valor e a norma deve ser tomada em consideração porquanto forma a estrutura dos delitos e, em especial, determina a importância e alcance do desconhecimento da ilicitude e a correspondente aplicação de pena ao autor que dela seja merecedor.

Diante desta perspectiva grande parte da doutrina afirma que o conhecimento da ilicitude deve ser analisado como um elemento da culpabilidade, sendo esta um elemento da teoria do delito. ${ }^{128}$ Ocorre que a aceitação do conhecimento da ilicitude como um elemento da culpabilidade faz surgir dúvidas aos defensores de uma teoria que fundamente o injusto na violação da norma (num aspecto puramente subjetivo) quando se esquecem de elemento valorativo imanente a toda norma e a todo sistema normativo. É neste sentido que se afirma que a norma demanda o conhecimento do mandato normativo, do que se deduz que o conhecimento da ilicitude deva integrar o injusto. Por isso Mir Puig afirmou que é razoável entender que os imperativos normativos requerem destinatários que possam recebê-los. ${ }^{129}$

Pois bem, a norma penal, como força impositiva de comportamentos, estabelece regras que têm como missão a proteção de bens jurídicos seja pela prática ou abstenção de condutas, seja determinando ou proibindo a produção de um estado de coisas, sempre com

\footnotetext{
${ }^{125}$ RAZ, Joseph. op. cit., p. 14.

${ }^{126}$ GARZON VALDES, Ernesto. El enunciado de la responsabilidad. DOXA, n. 19, p. 260 e ss., 1996. Vide, ainda, MIR PUIG, Santiago. Valoración, normas y antijuridicidad penal. In: DIEZ DIPOLLÉS, J. L.; ROMEO CASABONA, C. M.; GRACIA MARTIN, L.; HIGUERA GUIMERÁ, J. F. (Eds.). La ciencia del derecho penal ante el nuevo siglo: libro homenaje al prof. Dr. D. José Cerezo Mir. Madrid: Tecnos, 2002. p. 73 e ss.

${ }^{127}$ DE LA CUESTA AGUADO, Paz M. Conocimiento de la ilicitud: aproximación al conocimiento de la antijuridicidad del hecho desde las teorías psicológicas del pensamiento intuitivo. Madrid: Dykinson, 2007. p. 57.

${ }^{128}$ Id. Ibid., p. 58. Vide, ademais, críticas em MOLINA FERNANDEZ, Fernando. Antijuridicidad penal y sistema del delito. Madrid: Civitas, 2001. p. 478 e ss. e 588 e ss.

${ }^{129}$ MIR PUIG, Santiago. Valoración, normas y antijuridicidad penal, cit., p. 86 e ss.
} 
vistas à incolumidade de um ou mais bens jurídicos. Mas a questão é que ao Direito Penal não interessa tanto que o cidadão atue num ou noutro sentido ou que seja obediente à norma, mas que não ofenda bens jurídicos cuja proteção se busca pelas normas. E, neste exato ponto, é que surgem os questionamentos sobre a (des)necessidade de se conhecer ou poder conhecer a proibição, bastando que se afira se houve ou não lesão ao interesse juridicamente tutelado. Por isso, entende-se que o conhecimento da ilicitude é relevante como limite da imputação, não como fundamento da proibição. ${ }^{130}$

Partindo-se da ideia, então, que a teoria do delito também representa um esquema de imputação, pode-se entender a ilicitude como categoria objetiva do conceito analítico de delito que vincule o cidadão a uma noção ex ante de regras de conduta. Por outro lado, na culpabilidade verificam-se critérios subjetivos que têm funcionamento ex post, no momento de julgar a atribuição da conduta. ${ }^{131}$

Por todo o exposto, verifica-se que por mais que se possa discutir a composição analítica do delito, o problema do conhecimento da ilicitude é específico, passando pelo próprio entendimento do que seja a ilicitude e merecendo tratamento mais aprofundado, até mesmo providenciando-se uma releitura sobre seu papel e aplicação na teoria do delito, especialmente em face das características notadas no âmbito do fenômeno da expansão penal. É o que se pretende demonstrar nos capítulos que seguem.

\footnotetext{
${ }^{130}$ MIR PUIG, Santiago. Valoración, normas y antijuridicidad penal, cit., p. 86 e ss.

${ }^{131}$ FLETCHER, George P. El derecho y lo razonable. Trad. Donna y Barbero. Buenos Aires: Editorial de Belgrano, 1997. p. 57-60.
} 


\section{FUNDAMENTOS TEÓRICOS DO CONHECIMENTO DA ILICITUDE}

\subsection{Ponderações iniciais}

Historicamente, a atribuição de relevância ao conhecimento da ilicitude inserido no conceito de delito decorre dos entendimentos colhidos na teoria neoclássica. Veja-se que a teoria clássica entendia estarem inseridos no elemento "culpabilidade" tanto o dolo (um aspecto psicológico) como a culpa (um aspecto normativo), fazendo com que houvesse a busca por um elemento comum a ambos: o conhecimento da ilicitude. ${ }^{132}$ Assim, há quase meio século, Córdoba Roda já apontava que aquele conhecimento está intimamente relacionado com o caráter da norma, às funções do direito penal e da pena e, ainda, sobre a concepção de culpabilidade. ${ }^{133} \mathrm{E}$ tal assertiva merece atenção, porque é a partir do surgimento das relações entre o detentor do jus puniendi e seu destinatário que fará sentido a proibição e reprovação no âmbito da culpabilidade.

Também, quanto ao conhecimento da ilicitude, já se afirmou que, atualmente, se faz necessária uma análise multidisciplinar a partir do conhecimento científico do comportamento humano, deixando-se de lado a avaliação puramente feita sob perspectiva jusfilosófica e normativa. ${ }^{134}$ Assim, é de se considerar que a sociedade contemporânea é complexa, globalizada e cada vez mais composta pela coexistência de diferentes conceitos de moral e de valores observados sob a óptica da dignidade humana como bases para a convivência em comum. Isto implica, em outras palavras, na proteção à diversidade, levando a uma obrigatória renovação nas ideias, deixando as explicações de fundo metafísico e ideológico, para justificar a intervenção penal. De fato, conseguir explicar o conhecimento da ilicitude no Direito Penal em tempos atuais dependerá de releitura do próprio sistema.

Embora se possa entender que os meios de controle social sejam mais bem dirigidos por estímulos externos do que por normas, o conjunto de novas condições sociais pode levar o Direito Penal à sua máxima eficácia no controle social, uma vez que pode

\footnotetext{
${ }^{132}$ DE LA CUESTA AGUADO, Paz M. op. cit., p. 35.

${ }^{133}$ CÓRDOBA RODA, Juan. El conocimiento de la antijuridicidad en la teoría del delito. Barcelona: Bosch, 1992. p. 11.

${ }^{134}$ DE LA CUESTA AGUAdO, Paz M. op. cit., p. 19-20.
} 
ajudar na simplificação das complexidades. ${ }^{135} \mathrm{O}$ fundamental é que o Direito imponha coercitivamente normas jurídicas reguladoras de condutas e que, embora permita que o destinatário da norma escolha os motivos pelos quais a observa, essa observância seja coercitiva. O princípio básico é que o destinatário não questione a validez da norma. Desta forma, torna-se essencial para o Direito Penal que imponha as normas, mas que também se pense na legitimidade das regras presumidamente racionais fundadas em valores que se supõem legítimos.

Note-se que o problema é sério, uma vez que o Direito Penal pode e deve impor regras de conduta, mas sendo impositiva ponderação quanto a isso, em especial quais destas regras são tidas como legítimas baseando-se no que se pretende proteger sob coação de pena criminal.

Há, sem dúvida, uma dialética em virtude do caráter de subjetividade do destinatário. Não à toa, a discussão remete a entendimentos de que a culpabilidade é algo inerente à espécie humana, ainda que seja possível a discussão dos conceitos sob os vieses social e jurídico. Há tendência em aceitar-se a assertiva de que as sociedades admitem a diferenciação entre "culpados" e "inocentes", como separação entre os que merecem e os que não merecem juízo de reprovação. ${ }^{136}$ Nesse sentido, o Direito, mediante a imposição coercitiva de normas jurídicas referentes a regras de conduta, exerce a função de estabilização de expectativas que antes era promovida pelas autoridades sacras. ${ }^{137}$

Considerando-se, pois, o Direito Penal como conjunto de normas destinadas à regulamentação de condutas, sua finalidade passa pela existência de diferentes tipos de normas, com destinatários distintos e variados poderes de determinação quanto a condutas delitivas. ${ }^{138}$ Assim, haveria normas primárias de conduta cujo destinatário é o cidadão e uma perspectiva de processo exante vislumbrada como finalidade preventiva numa verdadeira tentativa de organização de condutas como forma de organização social. Por outro lado, haveria normas ditas secundárias, estas destinadas não aos cidadãos, mas ao Estado, ou falando-se de forma ampla, ao sistema judicial (basicamente aos juízes), com a finalidade processual ex post. São estas que determinam a qualificação delitiva de uma

\footnotetext{
${ }^{135}$ DE LA CUESTA AGUADO, Paz M. op. cit., p. 22. Para estudos sobre complexidade social, vide HARVEY, David. The condition of post modernity. Oxford: Blackwell, 1994.

${ }^{136}$ QUINTERO OLIVARES, Gonzalo. Locos y culpables. Pamplona: Aranzadi, 1999. p. 172. Vide, ademais, DE LA CUESTA AGUADO, Paz M. op. cit., p. 25.

${ }^{137}$ DE LA CUESTA AGUADO, Paz M. op. cit., p. 24.

${ }^{138}$ Sobre o Direito Penal ser esse conjunto de normas, vide ALCHOURRON, C.; BULYGIN, E. Análisis lógico y derecho. Madrid: Centro de Estudios Constitucionales, 1991. p. 393.
} 
conduta, as que estabelecem regras com vistas ao cumprimento da função limitativa do jus puniendi na medida em que determina parâmetros para a atribuição de responsabilidade penal a alguém. ${ }^{139}$

Verifica-se, então, que ambas as funções recém-comentadas são reflexo da tensão existente entre sujeito e sociedade que subjaz ao próprio Direito Penal e da qual se mostra reflexo e consequência. ${ }^{140}$ Nessa perspectiva de normas primárias e secundárias e, ainda, ponderando-se essa tensão entre as pessoas e a sociedade, encontra-se um elemento de suma importância, que é justamente o conhecimento do que se reputa ilícito. Conhecimento este que depende do modelo de sociedade que se pretende adotar e de que podem surgir ponderações das mais variadas ordens, como éticas, morais, religiosas, de política criminal etc. ${ }^{141} \mathrm{E}$, em um sistema político democrático há de se garantir a convivência de diferentes grupos sociais com sistemas de valores distintos, sendo imprescindível para que se imponham sanções a alguém, que a conduta formalmente proibida seja também materialmente legítima, evitando-se a exclusividade de motivos puramente coercitivos, autoritários.

No entanto, antes que se possa pretender discutir as bases teóricas e ou filosóficas quanto a uma sociedade democrática, há outros caminhos que devem ser trilhados, como o da uniformização sobre a terminologia adotada, sobre a generalidade ou especificidade da ilicitude, sobre a objetividade e subjetividade, formas de conhecimento e outras ponderações. Tais aspectos, por serem de grande importância para a sequência desta obra, representam fundamentos teóricos do conhecimento da ilicitude e serão apresentados logo adiante.

\footnotetext{
${ }^{139}$ MOLINA FERNANDEZ, Fernando. op. cit., p. 632. Sobre Direito Penal Democrático, vide CAAMAÑO, F. Garantía constitucional de la inocência. Valencia: Tirant lo Blanch, 2003. p. 16.

${ }^{140}$ WOLTER, Jürgen. Las causas constitucionales de exclusión del tipo, de injusto y de punibilidad como cuestión central de la teoría del delito en la actualidad. In: MIR PUIG, Santiago; LUZÓN PEÑA, DiegoManuel; DÍAZ Y GARCÍA CONLLEDO, Miguel (Dir.). Cuestiones actuales de la teoría del delito. Trad. Juan Manuel Paredes Castañón. Madrid: Interamericana de España; McGraw Hill, 1999. p. 10. Vide, ainda, CORTINA, Adela. Ética aplicada y democracia radical. Madrid: Tecnos, 1997. p. 134 e, também, da mesma autora, Hasta un pueblo de demonios: ética pública y sociedad. Madrid: Taurus, 1998. p. 62.

${ }^{141}$ Sobre as consciências sociais e dos tribunais, veja-se: MUGUERZA, Javier. El tribunal de la conciência y la conciência del tribunal (uma reflexión ético-jurídica sobre la ley y la consciência). Doxa, n. 15/16, p. 537, 1994.
} 


\subsection{Considerações sobre a terminologia: antijuridicidade, ilicitude, injusto e antinormatividade}

São muitas as ponderações a serem feitas quando se trata da temática "conhecimento da ilicitude" e, desta forma, considerando-se o universo jurídico - portanto, não só o sistema legal pátrio - importa ressaltar que é corrente o uso da expressão antijuridicidade, especialmente no continente europeu, todavia excluindo-se Portugal quanto a esse particular. Ao demonstrar tal utilização é que se aponta a clássica obra de Juan Córdoba Roda, que recebeu o título de "O conhecimento da antijuridicidade na teoria do delito". ${ }^{142}$

Fato é que o emprego da expressão "antijuridicidade" para fazer referência ao próprio injusto pode gerar alguma confusão no leitor. Nesse sentido, Fragoso, ao interpretar o pensamento de Welzel, asseverou que este teria se valido das expressões injusto e ilícito como sinônimas, diferenciando-as, ainda da antijuridicidade. ${ }^{143}$ Todavia, é possível constatar que Régis Prado, ao traduzir a obra do penalista alemão, apontou entendimento diverso, distinguindo os termos antijuridicidade e injusto sem ter feito qualquer menção à expressão "ilícito". ${ }^{144}$

Apesar de Díez Ripollés separar os conceitos de antijuridicidade e injusto, ${ }^{145}$ por outro lado, assevera-se que na Alemanha há emprego das expressões antijuridicidade e ilicitude como sinônimas. ${ }^{146}$ Felip i Saborit aponta também que na Espanha não há designação legal para o termo, de modo que a denominação empregada é consciência ou conhecimento do injusto, especialmente referindo-se a fato psicológico de efetiva representação do caráter proibido do fato quando da conduta e, ao mesmo tempo, é denominado "erro de proibição" a ausência dessa representação. ${ }^{147}$ Acrescenta, ainda, que é menos comum o uso do termo "compreensão do injusto", que, de qualquer forma se

\footnotetext{
${ }^{142}$ Tradução livre feita pelo autor deste trabalho cujo original é "El conocimiento de la antijuridicidad en la teoría del delito”. Barcelona: Bosch, 1962.

${ }^{143}$ FRAGOSO, Heleno Cláudio. Antijuridicidade. Revista Brasileira de Criminologia e Direito Penal, Disponível em http://www.fragoso.com.br/ptbr/arq_pdf/heleno_artigos/arquivo42.pdf>. Acesso em: 28 jun. 2011.

${ }^{144}$ WELZEL, Hans. O novo sistema jurídico-penal: uma introdução à doutrina da ação finalista. Tradução, prefácio e notas de Luiz Regis Prado. São Paulo: Ed. Revista dos Tribunais, 2001. p. 53.

${ }^{145}$ DÍEZ RIPOLLÉS, José Luis. La categoría de la antijuridicidad en derecho penal. ADPCP, t. 44, fasc. 3, p. 739,1991 . Afirma-se isso especialmente porque se pode encontrar no texto colocações sobre a gradação do injusto sob a óptica da antijuridicidade.

${ }^{146}$ JIMENEZ DE ASÚA, Luis. Tratado de derecho penal. 2. ed. Buenos Aires: [s.n.], 1961. p. 831.

${ }^{147}$ FELIP I SABORIT, David. La delimitación del conocimiento de la antijuricidad: una aportación al estudio del error de prohibición. Tese (Doutorado) - Universitat Pompeu Fabra - Barcelona, Espanha, 1997. p. 109.
} 
apresenta como sinônimo de consciência. ${ }^{148}$ Felip i Saborit assevera, ainda, que Jakobs, Timpe e Lesch preferem o uso desta última expressão - compreensão do injusto - para deixar claro que os parâmetros da culpabilidade (plena e reduzida) e sua exclusão não coincidem com os limites de tais conceitos exclusivamente psicológicos. ${ }^{149}$

Justamente por causa dessas situações, em que o emprego terminológico não se mostra sempre igual, urge comentar, ainda que brevemente, esclarecendo pontos tidos como fundamentais. Afinal, muitas são as expressões encontradas na literatura penal: ilicitude, antijuridicidade, antinormatividade e injuridicidade. ${ }^{150} \mathrm{E}$ essa variedade pode gerar alguma confusão, caso não sejam especificados seus significados. Ademais, tecnicamente é importante que haja uniformização terminológica em trabalhos científicos, de modo que não poderia ser diferente quando da redação deste. Eis a razão dessas breves palavras.

As diferentes vertentes que pretendem explicar os surgimentos da concepção de ilicitude como conceito autônomo se valem de nomenclaturas distintas. Assim, já se afirmou que a ilicitude, reconhecida como característica do fato punível podia ser verificada no direito romano, na forma de excludentes como a legítima defesa, embora se reconhecesse que não se tratava, até então, de um princípio geral. ${ }^{151}$

Por outro lado, pode-se dizer que um injusto penal é formado pela união entre institutos autônomos da categoria do delito: o tipo penal e a ilicitude. Nessa concepção, cabe ao tipo penal a descrição das condutas proibidas, sendo a ilicitude a relação de contradição entre a conduta e a ordem jurídica. ${ }^{152}$ Por seu turno, Roxin pondera que a ilicitude não representa uma peculiaridade do direito penal, sendo ela existente em todo o ordenamento jurídico e, desta forma, nega que o terceiro elemento do crime seja a ilicitude,

\footnotetext{
${ }^{148}$ FELIP I SABORIT, David. op. cit. Veja-se, para o uso da expressão "compreensão do injusto" (comprensión de lo injusto), ESER, Albin; Bjorn BURKHARDT. Derecho penal: cuestiones fundamentales de la Teoría del Delito sobre la base de casos de sentencias. Trad. Silvina Bacigalupo y Manuel Cancio. Madrid: Colex, 1995. p. 35.

${ }^{149}$ FELIP I SABORIT, David. op. cit., p. 110.

${ }^{150}$ HUNGRIA, Nelson. Comentários ao Código Penal. 6. ed. Rio de Janeiro: Forense, 1958. v. 1, p. 22. Quanto a esta última nomenclatura "injuridiciade", nota-se o uso prevalente por Nelson Hungria, não se mostrando um termo de uso corrente nos dias atuais. No entanto, apesar de usar tal termo, verifica-se, em sua obra, o uso de outras expressões, tais como "antijuridicidade" e "ilicitude". Pequeno excerto aqui transcrito auxilia nessa verificação: "Um fato, para ser criminoso, tem de ser, além de típico, contrário ao direito, isto é, estar positivamente em contradição com a ordem jurídica (...) Para se reconhecer que um fato típico é também antijurídico, basta indagar, dadas as circunstâncias que o acompanham, se não ocorre uma causa de excepcional licitude (causa excludente de crime, descriminante) (...)."

${ }^{151}$ FRAGOSO, Heleno Cláudio. op. cit.

${ }^{152}$ TAVARES, Juarez. Teoria do injusto penal. 3. ed. Belo Horizonte: Del Rey, 2003. p. 116.
} 
mas o injusto penal. ${ }^{153} \mathrm{O}$ autor acrescenta que os conceitos de ilicitude e de injusto diferenciam-se porque este representa conduta típica e ilícita, ao passo que aquela significa uma característica da conduta típica (contradição com as disposições legais). ${ }^{154}$

Também é de se apontar a expressão antinormatividade, mencionada pela doutrina penal, inclusive por Welzel, que entendia que as condutas proibidas pela norma, quando concretamente realizadas, faziam surgir a antinormatividade. ${ }^{155}$ Por seu turno, Zaffaroni, Alagia e Slokar, valendo-se do mesmo vocábulo, ponderam que do seu surgimento deriva conduta típica, isto é, da contradição entre o tipo isoladamente considerado, o que deve ser conjugado com outras normas proibitivas existentes na legislação em geral. ${ }^{156}$ Isso forma o que denominaram "tipicidade conglobante".

Aliás, esse entendimento sobre a necessidade de uma tipicidade conglobante importa que se considere não serem os tipos penais unidades autossuficientes. Pelo contrário, devem ser interpretados em conformidade com o ordenamento jurídico, considerado de forma global, isto é, não pode conceber que uma norma proíba o que outra ordena ou permite. ${ }^{157}$ Esse posicionamento exige que todo o ordenamento jurídico repudie certa conduta, não apenas um tipo penal, isoladamente considerado. ${ }^{158}$ Assim, tem-se a promoção de limites às tipificações porquanto devem ser observadas as proibições contidas, de forma geral, no ordenamento. ${ }^{159}$

Retornando ao pensamento de Welzel, este entendeu que a realização típica, apesar de antinormativa, nem sempre se mostra ilícita, uma vez que esta particular característica representa a contradição da realização do tipo ante o ordenamento jurídico. ${ }^{160}$ Por outro lado, é possível vincular a antinormatividade ao conceito formal de ilicitude, tendo-se em

\footnotetext{
${ }^{153}$ ROXIN, Claus. Derecho penal: parte general. 5 reimpr. Traducción de la 2 ed. alemana por Diego-Manuel Luzón Peña, Miguel Días, García Conlledo y Javier de Vicente Remesal. Madrid: Civitas, 2008. t. 1, p. 219.

${ }^{154}$ Id. Ibid., t. 1, p. 557-558.

${ }^{155}$ WELZEL, Hans. Derecho penal alemán. Trad. de la 11. ed. alemana por Juan Bustos Ramírez y Sergio Yáñez Pérez. Santiago de Chile: Editorial Jurídica de Chile, 1970. p. 76.

${ }^{156}$ ZAFFARONI, Eugênio Raúl; ALAGIA, Alejandro; SLOKAR, Alejandro. Manual de derecho penal: parte general. 2. ed. Buenos Aires: Ediar, 2006. p. 459.

${ }^{157}$ ZAFFARONI, Eugênio Raúl; PIERANGELI, José Henrique. Manual de direito penal brasileiro: parte geral. 9. ed. São Paulo: Ed. Revista dos Tribunais, 2011. v. 1, p. 474. E, acrescentam que, caso fosse diferente, que se permitisse haver conflito no ordenamento então "não se poderia falar de ordem normativa, e sim de um amontoado caprichoso de normas arbitrariamente reunidas."

${ }^{158} \mathrm{~A}$ ideia, assim colocada, faz evidenciar a necessidade de que se produzam normas penais observando-se uma política criminal.

${ }^{159}$ "De este modo se averigua la tipicidad objetiva conglobante, mediante el tipo conglobante, que es el conjunto de elementos del tipo objetivo que tomamos encuenta para afirmar la conflictividad." (ZAFFARONI, Eugênio Raúl; ALAGIA, Alejandro; SLOKAR, Alejandro. op. cit., p. 357).

${ }^{160}$ WELZEL, Hans. El nuevo sistema del derecho penal: una introducción a la doctrina de la acción finalista. Traducción y notas por José Cerezo Mir. 3. reimpr. Buenos Aires; Montevidéu: B de F, 2006. p. 89.
} 
vista que seria a contrariedade da conduta a uma norma jurídica expressa em um tipo penal. ${ }^{161}$ De fato, uma análise mais detida sobre este conceito faz ressaltar as construções formais de ilicitude. Essa concepção faz, então, que surjam confusões entre os conceitos supracitados, posto que se relacionam a contrariedade às normas.

Ainda, considerando-se tais ponderações, Fernandez anota diferentes formas de relacionar a ilicitude a partir das normas: vinculando-a à norma de comportamento - o que remete à teoria de Karl Binding ${ }^{162}$ (ilicitude equivaleria à antinormatividade) - ou, ainda, identificando-a com um requisito para incidência de norma sancionatória (ilicitude vinculada ao desrespeito à norma protegida). ${ }^{163}$ Em outras palavras e, ainda nesse sentido, porque a norma determina quais condutas são proibidas e permitidas, a ilicitude formalmente considerada pode ser entendida como a desobediência a essa norma e, assim, identifica-se com a antinormatividade. No que se refere à outra forma de análise, é preciso esclarecer que, nesse caso, tratar-se-ia a ilicitude como um verdadeiro pressuposto de aplicação das normas de sanção, algo como a expressão da reação do Estado verificada na forma de preceitos secundários das normas. ${ }^{164}$

Entre autores pátrios, Vargas não aceita a tese de que exista uma antijuridicidade geral, numa concepção de direito penal com a função puramente sancionadora. ${ }^{165}$ Seu questionamento é relativo à ideia de Binding, que considera alguns ramos do direito como os responsáveis por constituir as normas, relegando ao direito penal mero caráter sancionador a lesões verificadas em bens protegidos por outros ramos do direito. ${ }^{166}$

Visto isso, pode-se afirmar que o destaque do conteúdo material da ilicitude promove um afastamento daquela identificação com a antinormatividade, e esse

\footnotetext{
${ }^{161}$ Fernandez afirma que o conceito de antijuridicidade surgiu para expressar a contradição entre o comportamento de uma pessoa e o que foi determinado pela lei, de modo que "antijuridicidade e antinormatividade" são expressões que, na maior parte das vezes, são tidas como sinônimas. Assim, quando se quer diferenciar a antijuridicidade da antinormatividade, se empresta àquela o adjetivo "formal" (antijuridicidade formal). Vide: Antijuridicidad penal y sistema del delito, p. 63.

${ }^{162}$ Esse entendimento remete à teoria das normas de Binding, que teve três fases distintas. Inicialmente o autor afirmou que a antijuridicidade significava um comportamento contrário à norma em entendimento mais próximo a Merkel. MOLINA FERNANDEZ, Fernando. op. cit., p. 313). Ao depois, Binding se afasta de Merkel, passando a admitir diferentes funções das normas: a de determinação (reprovação pessoal ao autor pela sua desobediência à norma) e a valoração (juízo de desvalor objetivo de um fato que está em contradição com a norma). Nesse sentido: KÖSTER, Mariana Sacher de. Evolución del tipo subjetivo. Bogotá: Universidad Externado de Colombia 1998. p. 55-57. Ao final, a terceira etapa é a de que Binding pareceu sustentar ser a antijuridicidade numa lesão objetiva aos bens jurídicos, o que denota a concepção da antijuridicidade material. MOLINA FERNANDEZ, Fernando. op. cit., p. 27.

${ }^{163}$ MOLINA FERNANDEZ, Fernando. op. cit., p. 64.

${ }^{164}$ Id., loc. cit.

${ }^{165}$ VARGAS, José Cirilo de. Instituições de direito penal: parte geral. Belo Horizonte: Del Rey, 1997. t. 1, p. 318.

${ }^{166}$ Id. Ibid., p. 319.
} 
afastamento representa a concepção de que bens jurídicos precisariam ser violados. ${ }^{167}$ Isso representaria o conceito material e permitiria sustentar a função de determinação das normas. Nessa concepção, é certo que a antinormatividade não se apresentaria como sinônimo de ilicitude, posto que esta não poderia ser considerada meramente formal. Parece, então, ter ficado claro que a utilização dos termos antinormatividade e ilicitude como sinônimos surgiu, ao menos em parte, pela identificação da ilicitude com sua natureza formal (abstraindo-se o viés material de seu conceito).

Após esta incursão na diferenciação da antinormatividade e ilicitude, entende-se necessárias algumas ponderações sobre os conceitos e suas vertentes formal e material, importando compreender, ademais, como tais conceitos se adaptam à visão funcional.

Apontar a ilicitude como a necessária relação de contrariedade entre a conduta e a norma jurídica não é algo que se possa entender como novidadeiro. ${ }^{168}$ Afinal, essa noção remonta a análise da teoria do crime, precisamente aos tempos do causalismo. E, pelo menos, desde os estudos de Von Liszt há ideias considerando-se o viés material da ilicitude. $^{169}$

Com a dicotomia retroapresentada - vieses material e formal - pode-se considerar o surgimento de indagações como aquela sobre sua autonomia ou independência. Seriam formas complementares de análise do ilícito? Note-se que a questão posta em discussão é a seguinte: ao analisar-se a ilicitude formal e material, faz-se isso diferenciando-as conceitualmente (num entendimento de que sejam independentes) ou apenas e tão somente referem a aspectos de uma unidade conceitual (num entendimento de correspondência)? ${ }^{170}$

Considerando-se a tese de que representam conceitos independentes, a vertente material se mostra ligada a conceitos sociológicos de lesividade social. Então, por serem conceitos distintos, independentes, seria possível considerar um fato materialmente ilícito sem sê-lo sob a perspectiva formal, sendo o contrário igualmente possível.

Ademais, foi no sentido de contrapor-se a essa concepção de independência que se construiu o sistema causalista. Note-se que Beling não admitia que as normas de cultura

\footnotetext{
${ }^{167}$ Veja-se a obra MIR PUIG, Santiago. Derecho penal: parte general. 7. ed. 2 reimpr. Buenos Aires; Montevidéu: B de F, 2005. p. 156 e ss.

${ }^{168}$ É o que se encontra em TOLEDO, Francisco de Assis. Princípios básicos de direito penal. 5. ed. São Paulo: Saraiva, 1994. p. 161; MAURACH, Reinhart; ZIPF, Heinz. Derecho penal: parte general: teoría general del derecho penal y estructura del hecho punible. 7. ed. Buenos Aires, 1994. t. 1, p. 421; MIR PUIG, Santiago. Derecho penal: parte general, cit., p. 156, entre outros.

${ }^{169}$ REALE JÚNIOR, Miguel. Teoria do delito. 2. ed. rev. São Paulo: Ed. Revista dos Tribunais, 2000. p. 93.

${ }^{170}$ Defendendo a necessidade de diferenciação prática, MOLINA FERNANDEZ, Fernando. op. cit., p. 49.
} 
pudessem dar substrato à ilicitude, num entendimento de que não era possível considerar um fato socialmente lesivo uma vez que características sociológicas não poderiam formar um conceito jurídico. ${ }^{171}$

Von Liszt, por seu turno, notava que a noção material de ilicitude não se restringia às lesões a bens jurídicos, esclarecendo que uma conduta seria contrária ao direito quando representasse transgressão a uma proibição legal, sendo apenas ilegal quando tivesse sentido antissocial. ${ }^{172} \mathrm{O}$ que se pode notar é que parte da doutrina causalista vislumbrava a ilicitude em sentido meramente sociológico, deixando-o de lado, isto é, apesar de reconhecido como conceito autônomo, não lhe emprestavam validade jurídica.

E sendo assim, as ponderações são sobre a validade jurídica da ilicitude material, de modo que Fernandez expõe que aparentemente Von Liszt admitia que o conceito material fosse jurídico, o que significaria verdadeira aproximação entre os aspectos formais e materiais, em uma ideia que, apesar de rechaçar a independência, igualmente não assumia plenamente a teoria da correspondência dos vieses formal e material da ilicitude. ${ }^{173}$

Mas, esta primeira impressão pode ser questionada, tendo-se em vista a crítica feita por Roxin de que o conceito material de ilicitude em Von Liszt representava caráter metajurídico, sendo menos uma categoria jurídica e mais um princípio de política criminal. ${ }^{174}$ Mais precisamente se reconhece que o conteúdo material, isto é, o aspecto antissocial da infração é desvinculado da apreciação do legislador de forma que a ilicitude formal e material pode discrepar. Não se presume que haja esta discrepância, mas não se

\footnotetext{
${ }^{171}$ MOLINA FERNANDEZ, Fernando. op. cit., p. 49-50.

Quanto às normas de cultura, Mayer afirmou que as leis formam seu conteúdo a partir da cultura, de modo que o Direito e a cultura trilham juntos o caminho da conservação dos usos e costumes, da moralidade. A correspondência entre o direito e as normas de cultura se explica em parte pela influência que exerce a cultura sobre o direito e, ainda, pelo efeito recíproco entre eles (direito e cultura). Sua concepção é no sentido de que as pessoas não violam normas jurídicas, mas de cultura vez que o acesso cognitivo se dá, primeiramente, quanto àquelas, sendo a cultura um pressuposto para a aplicação da norma. As normas de cultura transformam-se em jurídicas quando reconhecidas pelo Estado. V. MAYER, Max Ernst. Normas jurídicas y normas de cultura. Traducción por José Luis Guzmán Dálbora. Buenos Aires: Hammurabi, 2000. p. 62.

${ }^{172}$ Reale Jr., concordando com a crítica de Rocco, sustenta que a ilicitude conceituada por Von Liszt era meramente formal, posto que a noção de ofensa ao bem jurídico se traduz no dano, que é um elemento do delito que tenha resultado natural (e não apenas da ilicitude). Esta continuava sendo uma contrariedade à norma, formalmente analisada. (REALE JÚNIOR, Miguel. Teoria do delito. 2. ed. rev., cit., p. 93-94.)

O que Rocco também afirmava era, em resumo, que a ilicitude formal era a única existente, posto que a noção material do conceito se ligava ao crime como um todo: ofensa a bem jurídico é um elemento do crime, com a ação e a culpa. (FRAGOSO, Heleno Cláudio. op. cit.).

${ }^{173}$ MOLINA FERNANDEZ, Fernando. op. cit., p. 51.

${ }^{174}$ ROXIN, Claus. Derecho penal: parte general. 5 reimpr., cit., t. 1, p. 561.
} 
considera impossível que exista. Neste caso, o juiz estará vinculado à lei e a retificação do direito positivo estará além de sua missão. ${ }^{175}$

Fernandez, no entanto, aponta a mudança de posicionamento de Von Liszt, que passou a ser adepto da teoria da independência, considerando-se a lesividade social de forma independente da apreciação feita pelo legislador e prévia à norma. Assim, parece prevalecer, pelo alemão, a tese de independência entre a ilicitude formal e material. ${ }^{176}$ As dúvidas quanto a esse posicionamento apareceram por causa da definição empregada à ilicitude material: seria jurídica, sociológica, extralegal ou um princípio de política criminal a reprovação a bens protegidos por normas jurídicas? O que se mostra certo é que os estudos de Von Liszt permitiram que se tomasse rumo a teorias mais modernas.

Atualmente, a perspectiva sociológica da ilicitude material tem sido deixada de lado, aceitando-a no plano do direito positivado. ${ }^{177}$ Sauer, ainda em meados do século XX, já sustentava a duplicidade no conceito, esclarecendo que o objeto do injusto é a conduta e, sua medida, é a antijuridicidade que, formalmente significa ilegalidade; no aspecto material significa contradição com a justiça social e ao bem comum, isto é, danosidade social por meio de periculosidade. ${ }^{178}$

Assim, sendo superada a fase teórica da independência, o conceito de ilicitude pode ser observado sob duas ópticas. ${ }^{179}$ A primeira delas identifica a ilicitude formal e material como perspectivas distintas de um único instituto, portanto perfeitamente relacionáveis, não se mostrando antagônicas. Eis o surgimento da teoria da correspondência. Considerase não haver muita praticidade nessa distinção.

Francisco de Assis Toledo considera desnecessária a distinção entre ilicitude formal e material, entendendo que se trata de conduta relevante para o direito penal somente situações em que possa ser verificada a contrariedade do fato à norma, além da violação ao bem jurídico tutelado. ${ }^{180}$ Em suma, o desvalor do resultado deve ser analisado conjuntamente ao desvalor da ação, para que se possa empregar alguma relevância da ilicitude ao Direito Penal.

\footnotetext{
${ }^{175}$ MOLINA FERNANDEZ, Fernando. op. cit., p. 51.

${ }^{176}$ Id. Ibid., p. 52.

${ }^{177}$ SAUER, Guillermo. Derecho penal; parte general. Traducción directa del alemán por Juan del Rosal y José Cerezo. Barcelona: Bosch, 1956. p. 95.

${ }^{178} \mathrm{Id}$., loc. cit.

${ }^{179}$ MOLINA FERNANDEZ, Fernando. op. cit., p. 54.

${ }^{180}$ TOLEDO, Francisco de Assis. op. cit., p. 162.
} 
A ideia de que os aspectos materiais e formais da ilicitude são inseparáveis levou Bettiol a dizer que não haveria razão para distinções, de forma que seria ilícita a lesão a um bem jurídico. ${ }^{181}$

A tese intermediária, que não se enquadra nem no viés da independência nem da correspondência, levou a entendimentos de que havia significado prático na distinção entre a ilicitude formal e material. Nessa perspectiva, Roxin aponta que a importância prática da antijuridicidade material é tripla, porque possibilita fazer gradações do injusto e aproveitálas dogmaticamente, também porque propicia meios auxiliares de interpretação para as teorias do tipo e do erro, auxiliando resolver problemas dogmáticos e, por fim, torna possível formular princípios a serem aplicados às causas de exclusão da ilicitude e determinar seu alcance. ${ }^{182}$

Tendo-se em conta a exposição acima, nota-se que algumas funções da ilicitude material fazem referência ao direito positivado. Por outro, também são notados vieses de conceituação político-criminal. De qualquer forma, a tensão em se aceitar as implicações político-criminais na ordem jurídica positiva deve perder o sentido, em uma ciência penal moderna. Afinal, como graduar o injusto, senão com elementos político-criminais de valoração da proibição conforme o grau de lesividade dos bens jurídicos tutelados pela ordem positiva? Formalmente, a ilicitude existe ou não, sem possibilidade de gradação. Por isto, a praticidade e conveniência da concepção material.

Da análise apresentada até aqui é possível afirmar que, conceitualmente, a ilicitude material leva em consideração a lesão a bem jurídico protegido pelo ordenamento jurídicopenal. Assim, numa ideia preliminar, não obstante haja a contradição da norma ao fato, será preciso, ainda, a lesão. Destarte, é esclarecedora a afirmação de que atualmente não há muito significado em fazer-se uma separação entre a ilicitude formal e material, tendo-se em vista a função essencial da proteção de bens jurídicos. ${ }^{183}$ Nesta visão, só a ilicitude material é capaz de exercer a função de proteção a certos interesses.

Em resumo, parece mais correto adotar-se um conceito material de ilicitude, não se admitindo o conceito meramente formal do instituto, que é associado à ideia de antinormatividade como mecanismo único de sua conceituação teórica.

\footnotetext{
${ }^{181}$ BETTIOL, Giuseppe. Direito penal, cit., v. 1, p. 335-336.

${ }^{182}$ ROXIN, Claus. Derecho penal: parte general. 5 reimpr., cit., t. 1, p. 559.

${ }^{183}$ VARGAS, José Cirilo de. op. cit., t. 1, p. 317.
} 
No Brasil, apesar de o Código Penal preferir o uso da expressão "ilicitude", majoritariamente se faz uso do termo "antijuridicidade" até mesmo alegando-se que na Europa ainda se prefere esta nomenclatura, somando-se o argumento de que as frequentes citações aos europeus induzem ao uso da mesma. ${ }^{184}$ De fato, o assunto é tormentoso, porque mesmo autores com obras específicas sobre o tema, por vezes se valem das expressões como sinônimas. ${ }^{185}$

Nesse cenário, cita-se Francisco de Assis Toledo, que sustenta que o termo "ilicitude traduz melhor a expressão alemã Rechtwidrigkeit", tendo esta o significado de “contrariedade ao ordenamento jurídico". ${ }^{186}$ Além disso, posiciona-se asseverando que não se trata de mero formalismo linguístico, uma vez que a expressão "antijurídico" se opõe a "jurídico" e questiona: “o antijurídico seria, então, ao mesmo tempo, jurídico?”. Acrescenta, ainda, que “a dicotomia 'lícito-ilícito' não padece de igual contradição, pois permite situar o crime, corretamente, na classificação dos fatos jurídicos, localizado na ramificação dos 'atos ilícitos', isto é, um fenômeno jurídico, mas com característica de ser contrário às normas objetivas do Direito." ${ }^{187}$ Reforçando seus argumentos, menciona, ainda, as lições de Carnelutti, que notou a impropriedade do termo antijuridicidade. ${ }^{188}$

Como dito, nosso Código Penal, passada a reforma de 1984, adotou a terminologia “ilicitude", preterindo a expressão "antijuridicidade", antes empregada pelo código de 1940 e que havia sido majoritariamente usada em países europeus.

Tendo estas palavras em consideração, pode-se, então, afirmar que não se deveria falar em atos ou fatos antijurídicos, porquanto sejam regulados pelo ordenamento de modo que os fatos e atos são, na estrutura jurídica positivada, proibidos ou ilícitos, tendo razão Assis Toledo. Com base no exposto, à exceção de transcrições de obras no original, quando se deverá fazer uso da expressão "antijuridicidade", a terminologia a ser adotada no presente trabalho é "ilicitude" (“conhecimento ou consciência da ilicitude”).

\footnotetext{
${ }^{184}$ Por todos, vide BITTENCOURT, Cezar Roberto. Tratado de direito penal: parte geral. 13. ed. São Paulo: Saraiva, 2008. p. 295.

${ }^{185}$ Por exemplo, DE LA CUESTA AGUADO, ainda na capa da sua obra faz uso das duas expressões, como se verifica pelo título: Conocimiento de la ilicitud. Aproximación al conocimiento de la antijuridicidad del hecho desde las teorías psicológicas del pensamiento intuitivo, cit.

${ }^{186}$ TOLEDO, Francisco de Assis. O erro no direito penal. São Paulo: Saraiva, 1977. p. 70.

${ }^{187}$ Id. Ibid., p. $70-71$.

${ }^{188}$ Id. Ibid. Quanto a Carnelutti, mencionou-se a obra traduzida para o espanhol Teoria general del delito. Trad. Victor Conde. Madrid: Editorial Revista de Derecho Privado, 1952. p. 18 e ss.
} 


\subsection{Ilicitude genérica e específica}

Já se disse que o injusto penal compõe-se do tipo legal e da ilicitude. Pode haver, no entanto, questionamentos quanto à essência desse conceito, de modo que se indague a diferença do injusto penal para o de outros ramos do direito. Esse tipo de questionamento pode vir à tona em virtude de conjecturas sobre a existência de uma ilicitude geral, o que pode trazer reflexos ao conceito de injusto penal.

Nesse ponto, verificam-se ponderações feitas pela doutrina sobre a tese da existência de uma ilicitude geral (que abarcaria os ramos não penais), cabendo ao direito penal um aspecto meramente sancionador. ${ }^{189}$ Nesse sentido, rechaça-se o entendimento de que quanto ao Direito Penal não se pode falar da violação de normas, mas apenas e tão somente de sanção. ${ }^{190}$

Considerando-se que o direito penal não representa mera sanção, o entendimento seria o de que este ramo do direito é o responsável pela determinação do objeto de tutela, o que traz à baila a noção de bem jurídico. Não seria, então, o ramo criminal responsável por exercer papel punitivo sobre violações a normas provenientes de outros ramos, negando-se, ainda, que a subsidiariedade tanto apontada como característica deste ramo se preste a comprovar seu caráter puramente sancionador. ${ }^{191}$

Alega-se, nesse sentido, que a subsidiariedade adviria de uma urgência constitucional, pressupondo a existência de limites à discricionariedade política de se recorrer ao ramo penal mas, que, apesar disso, tal fato não autorizaria o entendimento de que o direito penal tem caráter meramente sancionatório. Assim, afirma-se que a Constituição tem função fundamentadora e limitadora ao passo que a punição estatal ganha legitimidade ao proteger bens jurídicos - expressões de direitos fundamentais - e, ainda, porque se constata que a intervenção penal deve observar a proporcionalidade, a

\footnotetext{
${ }^{189}$ VARGAS, José Cirilo de. op. cit., t. 1, p. 318-319.

${ }^{190}$ Id., loc. cit.

${ }^{191}$ Paulo Queiroz trata da subsidiariedade sob duas ópticas: tanto no sentido social-político (intervenção penal quando outras instâncias de controle social tenham fracassado) quanto no sentido lógico-sistemático (definição do caráter subsidiário ou constitutivo em relação aos outros ramos do Direito). QUEIROZ, Paulo. Direito penal: parte geral. 6. ed. Rio de Janeiro: Lumen Juris, 2010. p. 37.
} 
ofensividade e a intervenção mínima, por exemplo. Essa seria uma forma de se atribuir ao ramo penal o caráter de subsidiariedade. ${ }^{192}$

Os questionamentos sobre o caráter genérico ou específico da ilicitude ainda podem ser vistos sob outra óptica. Isto é, ainda que se refute a essência puramente sancionatória do direito penal, não se nega, por outro lado, haver um conceito geral de proibição no ordenamento jurídico. Caberia, então, aos demais ramos jurídicos que determinassem o uso da proibição na seara específica de atuação do referido ramo, não se verificando, destarte, uma ilicitude penal diferente das extrapenais. Tal posicionamento é questionado por Toledo, que, por seu turno, entende existir uma ilicitude penal distinta de outra, extrapenal de modo que "um ilícito civil ou administrativo pode não ser um ilícito penal, mas a recíproca não é verdadeira". 193

Explica-se o que fora dito acima. Os diversos ramos jurídicos selecionam comportamentos que se subsumem a proibições gerais que se prestam a tutelar as finalidades das searas jurídicas específicas, isto é, as ramificações jurídicas criam objetos de proteção desde a ideia geral de proibição do Direito. Assim deveria ser com o Direito Penal que, de acordo com as suas finalidades, tipificaria condutas que já são consideradas ilícitas no ordenamento penal. Somente se repete a ressalva: tal postura não significa afirmar que o Direito Penal é meramente sancionador.

Quanto ao fato de selecionar seu objeto de proteção, Muñoz Conde afirma que o direito penal não cria a ilicitude, mas a seleciona, valendo-se da tipicidade, parte dos comportamentos, geralmente os mais graves, cominando penas. ${ }^{194}$

Curiosa é a questão das condutas tipificadas pelo direito penal que nunca foram alvo de discussões envolvendo outros ramos do direito, nem por eles tutelada. Poder-se-ia afirmar que isso sugeriria proibições implícitas pelo ordenamento? Seria isso a ilicitude especial? Tal situação parece representar muito mais a criação geral do ordenamento feita pelo direito penal por falta de regulamentações anteriores que outra coisa. Essa proibição

\footnotetext{
${ }^{192}$ Nesse sentido, GOMES, Luiz Flávio. Princípio da ofensividade no direito penal. São Paulo: Ed. Revista dos Tribunais, 2002. p. 16 e ss. Paulo Queiróz aponta que a determinação da proteção penal se mostra ligadaà ideia de ofensas a bens jurídicos, que estão relacionados a direitos fundamentais. Assim, respeitar a ofensividade representa conferir ao ramo penal caráter de respeito aos direitos fundamentais. Ao mesmo tempo, essa consideração não implica considerar o Direito Penal meramente sancionatório, até mesmo porque caso assim se entendesse então todos os demais ramos do Direito teriam essa mesma natureza, haja vista a Constituição determinar as valorações essenciais da ordem jurídica. Em suma, "toda a ilicitude nasce originariamente na Constituição Federal e só derivadamente na ordem infraconstitucional." (QUEIROZ, Paulo. op. cit., p. 37).

${ }^{193}$ TOLEDO, Francisco de Assis. Princípios básicos de direito penal, cit., p. 165.

${ }^{194}$ MUÑOZ CONDE, Francisco. Teoría general del delito. 2. ed. Bogotá: Temis, 2008. p. 65.
} 
será aplicável não só ao Direito Penal, mas a outros ramos do direito, o que não a torna específica, apesar de ter ingressado no ordenamento pelo Direito Penal. ${ }^{195}$

A defender a ideia de que não há um conceito especial de ilicitude, pode-se mencionar Sauer, que entende que o conteúdo do injusto no direito penal é também obrigatório para outros ramos, de modo que o direito penal não tem uma concepção própria de injusto. ${ }^{196}$ Assim, falar de um conceito específico de ilicitude penal seria uma ideia equívoca.

Aníbal Bruno esclarece que "Um fato que se apresenta como antijurídico em face de qualquer ramo do Direito conserva esse atributo de antijuridicidade em referência a qualquer outro domínio jurídico. Não há, portanto, uma antijuridicidade penal, mas podese falar, como sugere Welzel, em um ilícito penal, ou um ilícito administrativo, ou um ilícito civil. O ilícito penal é aquele a que se junta o atributo da tipicidade. É o ilícito típico". ${ }^{197}$ Nesse sentido, a ilicitude é vista como geral, inerente a todo ordenamento jurídico e, particularmente quanto ao direito penal, lhe é peculiar o injusto, ou ilicitude tipificada.

Pode-se concluir, portanto, que a ilicitude é um instituto geral do Direito, podendo o ramo penal deixar de atuar diante de certas situações - ainda que não admitidas em outros ramos do direito - seja pela subsidiariedade, seja pela ultima ratio a ser aplicada, de forma que, em última análise, uma conduta poderia ser ilícita sem que fosse alvo de tipificação penal. ${ }^{198}$

Nessa perspectiva, há quem defenda que para a intervenção penal emergir seria preciso considerar-se a dignidade do bem jurídico e a ofensividade da lesão, sendo que, noutro momento analisar-se-ia a necessidade da intervenção penal e, ainda, sua adequação

\footnotetext{
${ }^{195}$ É interessante a posição de Sauer: "Hay un concepto especial de 'antijuridicidad penal' solamente encuanto que la definición dada ahora mismo no se acomoda as otras matérias jurídicas que ni gravitan en tipos estrictamente concebidos ni en las causas de justificación; el contenido del injusto en el Derecho Penal es también obligatorio para otras matérias, como también al contrario. El Derecho Penal no tiene ninguna concepción, propia del 'injusto', encuanto un concepto especial de antijuridicidad penal es equívoco.” (SAUER, Guillermo. op. cit., p. 104).

${ }^{196}$ Id., loc. cit.

${ }^{197} \mathrm{O}$ trecho acima transcrito ganha mais clareza quando se entende o termo "ilícito" com significado de “injusto”. BRUNO, Aníbal. Direito penal: parte geral, cit., t. 1, p. 223.

${ }^{198}$ Em perfeita síntese desta necessária constitucionalização do Direito Penal, Alice Bianchini anota que os pressupostos mínimos para a intervenção penal podem ser divididos em três momentos: primeiro verificase a dignidade do bem jurídico (se pode ou não ser tutelado por meio de intervenção penal), bem como analisa-se a ofensividade da lesão; em segundo plano, determina-se a necessidade da tutela penal; por fim, resolve-se a questão da eficácia e da adequação da intervenção penal. (BIANCHINI, Alice. Pressupostos mínimos da tutela penal. São Paulo: Ed. Revista dos Tribunais, 2002. p. 18-19).
} 
e eficácia. ${ }^{199}$ Ao mesmo tempo, é de se considerar que, de forma contrária, não poderia o direito penal imiscuir-se em proibir condutas admitidas em outros ramos do direito, haja vista a ilicitude ser geral para a ciência jurídica. Nesse sentido, Figueiredo Dias esclarece que, sendo uma conduta ilícita por um só ramo do ordenamento, torna-se ela ilícita para a sua totalidade e, de forma inversa, sendo lícita para um dos ramos jurídicos, também o é considerando-se sua totalidade. ${ }^{200}$ Isso leva ao entendimento de que os ramos do direito podem até divergir quanto à regulamentação do tratamento a ser dispensado a certa conduta, todavia não pode valorar antagonicamente a mesma conduta. ${ }^{201}$

Também são adeptos desse entendimento Zaffaroni, Alagia e Slokar, que argumentam não haver ilicitude específica, especialmente quando argumentam que adotar o critério da ilicitude como juízo definitivo sobre a proibição de uma conduta pressupõe considerar a ordem jurídica como uma totalidade para a qual a conduta será lícita ou ilícita. ${ }^{202}$ Advertem, contudo, tais autores no sentido de que uma equivocada interpretação sobre a compreensão da ilicitude geraria transtornos quanto ao entendimento de como deve ser a responsabilidade pelos atos praticados. Isto é, não seria acertado negar a existência de responsabilidade a uma pessoa que tenha cometido um ato típico, porém justificado. ${ }^{203}$ Nesse sentido, exemplificam asseverando que a responsabilidade penal, mesmo quando justificada, poderá não excluir responsabilidades de outros ramos, como ocorreria com o estado de necessidade. ${ }^{204}$

Mezger também adotava entendimento nesse sentido - quanto à inexistência de uma ilicitude específica - especialmente quando afirmava que o injusto específico do direito penal não tem relação com uma ilicitude especial. ${ }^{205}$ Fica claro, então, que o alemão

\footnotetext{
${ }^{199}$ BIANCHINI, Alice. op. cit., p. 18-19.

${ }^{200}$ DIAS, Jorge de Figueiredo. Direito penal: parte geral: questões fundamentais: a doutrina geral do crime. 2. ed. portuguesa, 1. ed. brasileira. São Paulo: Ed. Revista dos Tribunais, 2007. t. 1, p. 388.

${ }^{201}$ Figueiredo Dias se vale da seguinte passagem para fixar seu entendimento: "No mais que os diferentes ramos de direito podem divergir é numa diferente regulamentação das consequências jurídicas, não numa diversa valoração do tatbestand como respeitador ou violador da ordem jurídica, como um todo". DIAS, Jorge de Figueiredo. Direito penal: parte geral, cit., t. 1, p. 388.

${ }^{202}$ ZAFFARONI, Eugênio Raúl; ALAGIA, Alejandro; SLOKAR, Alejandro. op. cit., p. 463.

${ }^{203}$ Id., loc. cit.

${ }^{204}$ Corroboram esse entendimento os arts. 65 e 66 do Código Penal Brasileiro, que dispõem, respectivamente que "Faz coisa julgada no cível a sentença penal que reconhecer ter sido o ato praticado em estado de necessidade, em legítima defesa, em estrito cumprimento do dever legal ou no exercício regular de direito" e, ainda, "Não obstante a sentença absolutória no juízo criminal, a ação civil poderá ser proposta quando não tiver sido, categoricamente, reconhecida a inexistência material do fato."

${ }^{205}$ MEZGER, Edmund. Tratado de derecho penal. Nueva edicion, revisada y puesta al dia por José Arturo Rodriguez Munoz. Madrid: Editorial Revista de Derecho Privado, 1955. t. 1, p. 374-375. Miguel Reale Júnior entende que também para Mezger haveria normas de direito e de dever implícitas de modo a verificar-se uma hierarquia superior da norma dispositiva. Afinal, "a função dispositiva deriva da valoração objetiva, aspecto nuclear do direito, que determina a licitude ou ilicitude de uma situação, enquanto a
} 
não crê em uma ideia de ilicitude penal diferente de outra, geral do ordenamento, não se criando proibições especiais para o Direito, isto é, entende que a formação do tipo penal torna a proibição geral.

Quanto à generalidade ou especificidade, com mais detalhamento se poderá notar ponderações no Capítulo 4, que pretende delinear aspectos das ilicitudes penal e administrativo-sancionadoras, numa busca pela fixação de critérios que se prestem a auxiliar o conhecimento da ilicitude.

\subsection{Ilicitude objetiva e subjetiva}

Ao estudar-se a ilicitude é possível encontrar posicionamentos adeptos de concepções tanto objetiva quanto subjetiva.

Diz-se que a concepção objetiva funda-se nos estudos de Kant, ${ }^{206}$ e, nesse sentido, Everardo Cunha Luna afirmou que para a vertente objetiva tem-se a ilicitude como a violação da norma, ao passo que a corrente subjetivista mistura os conceitos de ilicitude com culpabilidade. ${ }^{207}$ Para a vertente objetiva, o antagonismo entre a conduta e a ordem jurídica é o responsável por delimitar a ilicitude de modo que os atos humanos, quando valorados negativamente pelo ordenamento jurídico, serão ilícitos. Tal valoração é feita de forma objetiva em face de violações a valores positivados pelo Direito.

Bettiol foi adepto da corrente objetivista, que não leva em consideração a ligação psicológica entre o autor e o fato. ${ }^{208} \mathrm{O}$ autor afirmava que a ilicitude encerra juízo sobre a lesividade do fato praticado, portanto detém um caráter objetivo, o que se contrapõe ao entendimento de que a ilicitude compõe uma característica do fato, abrangendo o agir externo e interno, isto é, confundindo-se com um conceito de culpabilidade. ${ }^{209}$ Bettiol valeu-se do argumento de haver duas funções das normas - valorativa e imperativa - para

obrigação de obediência, voltada para um destinatário singular, só pode existir como derivada daquela valoração. Não é de relevo para que uma situação seja lícita que haja ou não desrespeito à norma de dever, como determinação subjetiva, questão atinente, apenas, à culpabilidade.” (REALE JÚNIOR, Miguel. Teoria do delito. 2. ed. rev., cit., p. 65).

${ }^{206}$ LUNA, Everardo da Cunha. Estrutura jurídica do crime. 2. ed. Recife: Imprensa Universitária Universidade Federal de Pernambuco, 1968. p. 135.

${ }^{207}$ LUNA, Everardo da Cunha. op. cit., p. 43.

${ }^{208}$ BETTIOL, Giuseppe. Direito penal, cit., v. 1, p. 323-324.

${ }^{209}$ Id., loc. cit. 
que justifique sua opção por uma vertente objetiva. ${ }^{210}$ Nesse ponto Mezger assemelha-se a ele. ${ }^{211}$ Fato é que, nessa perspectiva, o momento valorativo da norma é pré-jurídico, e o momento posterior à criação da lei representa a inutilidade em que se separe valoração da norma da conduta (não haveria significado prático).

Miguel Reale Júnior ressalta que, para Mezger, a norma penal era composta por normas de direito e de dever, havendo uma hierarquia superior da norma dispositiva (de direito) na medida em que "a função dispositiva deriva da valoração objetiva, aspecto nuclear do direito, que determina a licitude ou ilicitude de uma situação, enquanto a obrigação de obediência, voltada para um destinatário singular, só pode existir como derivada daquela valoração. Não é de relevo para que uma situação seja lícita que haja ou não desrespeito à norma de dever, como determinação subjetiva, questão atinente, apenas, à culpabilidade.,212

Contrapondo-se à concepção objetiva de ilicitude, há o argumento de que naquele entendimento existe uma singela preocupação com o resultado lesivo a bens jurídicos protegidos, não se ponderando subjetivamente a conduta. Esse entendimento admite que a subjetividade acrescida à ilicitude faria com que o desvalor da ação e do resultado tivesse relevância mais próxima, assim o caráter proibido da norma seria identificável pela intenção do agente na apreciação da conduta. Em outras palavras, defende-se a ideia de que a ilicitude não pode ser concebida sem que se remeta à noção de desrespeito ao comando normativo, ou seja, deveriam ser inafastáveis aspectos valorativos e imperativos a título de complemento. Em última análise, as disposições legais não determinam e tampouco produzem valoração isoladamente.

Nesse sentido, Miguel Reale Júnior afirma que os subjetivistas veem o direito penal como incidente em fatos ocorridos no mundo exterior, ao passo que suas consequências são dirigidas às condutas daqueles que fossem capazes de responder ao que fora imposto e valorado pelas normas. ${ }^{213} \mathrm{O}$ autor prossegue esclarecendo que "a antijuridicidade se refere à ação realizada em posição axiológica conflitante com um valor tutelado pelo direito. Quando não se tem ciência de que o valor é tutelado pelo direito, a ação é antijurídica,

\footnotetext{
${ }^{210}$ BETTIOL, Giuseppe. Direito penal, cit., v. 1, p. 325.

${ }^{211}$ MEZGER, Edmund. Derecho penal: libro de estúdio: parte general. Traducción de la 6 ed. alemana por Conrado A. Finzi. Buenos Aires: Librería El Foro, 1957. t. 1, p. 134.

${ }^{212}$ REALE JÚNIOR, Miguel. Teoria do delito. 2. ed. rev., cit., p. 65.

${ }^{213}$ Id. Ibid., p. 71.
} 
porém não reprovável", 214 e conclui que valorar negativamente uma conduta não significa ter o conhecimento da ilicitude.

Assis Toledo conclui, quanto a isso, que houve tentativa de organização das vertentes objetiva e subjetiva sob uma óptica finalista. ${ }^{215}$ Assim, a inclusão da subjetividade no injusto penal representou mudança paradigmática, encerrando a ideia de injusto pessoal, avocando características da culpabilidade para o tipo, precisamente o aspecto subjetivo. Portanto, afirma que a doutrina finalista deslocou a vontade para o centro do conceito de ilicitude, próximo à ameaça de lesão ao bem jurídico tutelado. ${ }^{216}$

E, mencionando-se o finalismo, cabe lembrar que Welzel afirmava que a ilicitude é um juízo de desvalor que recai objetivamente sobre uma dada conduta, fundamentando-se no ordenamento jurídico. ${ }^{217}$ Assim, a conduta poderia ser considerada como a conjugação de elementos objetivos - os do mundo exterior - e subjetivos - os anímicos. O autor esclarece, ainda, que diante da equivocidade do conceito "objetivo" é que constantemente tinha-se a ideia de que a ilicitude somente conteria um viés objetivo. Por isso afirmava que a ilicitude só era considerada objetiva no sentido de um juízo valorativo geral já que seu conteúdo - a conduta - representa unidade de elementos subjetivos (do mundo exterior) e subjetivos (anímicos). ${ }^{218}$

Sobre a subjetivação do injusto penal há, entretanto, outra interpretação. Zaffaroni argumenta que existe confusão terminológica relevante que gerou entendimentos destoantes, confundindo-se injusto com ilicitude e, ainda, porque não se tinha clareza na concepção do caráter objetivo da ilicitude. ${ }^{219}$ Todavia, deve-se ponderar que esse posicionamento deriva do entendimento do autor de que são sinônimos os termos injusto penal e ilícito e, ainda, a expressão "antijuridicidade" como sinônimo de "ilícito". Tal confusão terminológica já foi assinalada anteriormente, e deve-se frisar que para parte da doutrina alemã não há separação entre os termos injusto, ilícito e antijuridicidade. Já foi dito que, neste trabalho, faz-se a divisão entre o conceito de injusto (que os alemães também denominam ilícito) e ilícito (que os alemães denominam antijuridicidade). Tudo conforme dito anteriormente.

\footnotetext{
${ }^{214}$ REALE JÚNIOR, Miguel. Teoria do delito. 2. ed. rev., cit., p. 87.

${ }^{215}$ TOLEDO, Francisco de Assis. Ilicitude penal e causas de sua exclusão. Rio de Janeiro: Forense, 1994. p. 7. ${ }^{216}$ Id., loc. cit.

${ }^{217}$ WELZEL, Hans. O novo sistema jurídico-penal: uma introdução à doutrina da ação finalista, cit., p. 52.

${ }^{218}$ Id., loc. cit.

${ }^{219}$ ZAFFARONI, Eugênio Raúl; ALAGIA, Alejandro; SLOKAR, Alejandro. Manual de derecho penal: parte general, cit., p. 467.
} 
Zaffaroni também afirma que o finalismo trouxe ao injusto penal aspectos subjetivos e afirma que a ilicitude compõe o injusto, não significando seu conteúdo total. ${ }^{220}$ Apesar disso, localiza diversamente a subjetividade do injusto, entendendo a ilicitude em seu viés objetivo, isto é, argumenta que a ilicitude é objetiva porque a conduta concretamente considerada é determinada a partir de um juízo de valor fático e não valorativo. $^{221}$ Ademais, diz que o juízo subjetivo é realizado pela norma, que a ela dá concretude a partir das liberdades constitucionais e a partir da ausência de proibições no ordenamento; desta forma, enquanto o legislador realiza um juízo prévio, valorativo, o julgador realiza um juízo objetivo, fático. ${ }^{222}$ Afirma também ser objetiva a ilicitude, ao passo que não leva em consideração a motivação do sujeito ao praticar a conduta. ${ }^{223}$

Nota-se que o argentino se vale de argumentos semelhantes aos de Bettiol ao ponderar comandos imperativos e valorativos da norma penal, separando, ainda, momentos legislativos e judicantes na avaliação da proibição da conduta. Todavia, Zaffaroni aceita o injusto finalista, subjetivado. Bettiol, ao contrário, entende que a relação psicológica entre autor e evento fica na culpabilidade. ${ }^{224}$ De fato, Bettiol afirmou que, para que não se estabelecessem confusões, e considerando-se a culpabilidade sob a óptica normativa, não se poderia conceber a inexistência do liame psicológico do autor com o fato, sendo esta ligação sempre necessária. Entendia que a culpabilidade não representava mais um dado psicológico-naturalístico, mas um juízo que depende da existência de elementos, como o nexo psicológico entre o autor e o fato. ${ }^{225}$

Maurach e Zipf, quanto às funções normativas, entendem ser evidente a característica impositiva do direito, mas afirmam não existir ordem sem uma situação anterior, sem um pressuposto. Assim, se o ordenamento determina que se faça ou que se deixe de fazer algo é porque, antes, valorou a conduta e reconheceu seus aspectos bons e ruins. É nesse sentido que se fala de uma função de valoração e determinação do direito e, entre estas, não cabe pôr em dúvida a preeminência temporal e lógica correspondente à primeira. $^{226}$

\footnotetext{
${ }^{220}$ ZAFFARONI, Eugênio Raúl; ALAGIA, Alejandro; SLOKAR, Alejandro. op. cit., p. 468.

${ }^{221}$ Id., loc. cit.

${ }^{222}$ Id., loc. cit.

${ }^{223}$ Id., loc. cit.

${ }^{224}$ BETTIOL, Giuseppe. Direito penal. Tradução de Paulo José da Costa Jr. e Alberto Silva Franco. Notas de Everardo da Cunha Luna. São Paulo: Ed. Revista dos Tribunais, 1971. v. 2, p. 12.

${ }^{225}$ Id., loc. cit.

${ }^{226}$ MAURACH, Reinhart; ZIPF, Heinz. op. cit., t. 1, p. 419.
} 
Para Zaffaroni tem-se, então, que a valoração da proibição é prévia quanto à elaboração do tipo. É nesse momento antecedente que se faria a valoração da ilicitude, tipificando-se, apenas e tão somente condutas aptas a ofender a integridade de bens jurídicos, havendo, portanto, um conteúdo subjetivo da ilicitude antecedente à tipificação. Ocorre que o autor argentino funda a valoração do tipo a partir da antinormatividade.

Ao realizar a análise judicial da conduta praticada pelo agente, tem-se um caráter objetivo, uma constatação fática da proibição prevista no tipo de modo que a subjetivação judicial da ilicitude significaria estabelecer uma mescla com a culpabilidade. ${ }^{227}$

Em suma, restaria à culpabilidade a análise da imputabilidade, do potencial conhecimento da ilicitude e a exigibilidade de conduta diversa. Nesse particular, analisarse-ia a função imperativa da norma.

Entretanto, percebe-se que, em determinadas situações, existem parcelas típicas que condicionam subjetivamente a ilicitude na sua concretização: os elementos subjetivos do injusto. Os limites entre o objetivo e o subjetivo se confundem nestes casos. Mas a situação ainda é trabalhada dentro da tipicidade, posto que se adota o tipo total do injusto.

Figueiredo Dias afirma que os elementos subjetivos do injusto não têm relação com os elementos objetivos do ilícito, quando diferencia os elementos subjetivos - que prefere chamar de "especiais elementos subjetivos do tipo" - esclarecendo que os elementos subjetivos, quando ausentes, excluem o tipo de ilícito. ${ }^{228}$ Esses elementos subjetivos são integrados à vontade do agente e, como são expressões da vontade, existem apenas na modalidade dolosa, que se diferenciariam de outros, acréscimos ao ânimo do agente, formadores dos elementos subjetivos do injusto.

Nesse ponto, Mezger abriu caminho para o que seria a futura concepção do injusto pessoal, ao ter sistematizado os elementos subjetivos, embora os tenha concebido de forma excepcional. $^{229}$ Importante salientar, ainda, que Mayer igualmente admitiu apreciação subjetiva do injusto penal de forma excepcional. O autor afirmou que os elementos subjetivos da ilicitude são autênticos atributos do instituto, mas não compõem a

\footnotetext{
${ }^{227}$ Nesse sentido, MAURACH, Reinhart; ZIPF, Heinz. op. cit., t. 1, p. 420.

${ }^{228}$ DIAS, Jorge de Figueiredo. Direito penal: parte geral, cit., t. 1, p. 379.

${ }^{229}$ VARGAS, José Cirilo de. Do tipo penal. 3. ed. Rio de Janeiro: Lumen Juris, 2008. p. 40.
} 
culpabilidade de modo que não têm um duplo caráter, a exemplo dos pressupostos da pena examinados sob a óptica da tipicidade e da ilicitude. ${ }^{230}$

Nesta linha de raciocínio, como dito acima, na etapa legislativa já haveria um juízo de (des) valor, portanto precedente à tipificação, isto é, em primeiro lugar se verificaria a contrariedade da conduta aos valores instituídos no ordenamento jurídico. Esta fase englobaria juízos objetivos e subjetivos pelo legislador para que se constitua o tipo penal. Depois, já na fase judicante, a verificação da ilicitude é objetiva.

\subsection{Formas de conhecimento da ilicitude}

Já se disse que é comum que as pessoas atuem sem que estejam plenamente seguras de estarem realizando conduta ilícita e que, não tendo certeza da ilicitude, atuam considerando que a contrariedade ao direito é apenas possível. ${ }^{231}$ Coloca-se em debate, então, a questão relativa ao grau de certeza necessário para a constatação da existência do conhecimento da ilicitude ou, do contrário, da aplicação do erro de proibição (vencível ou invencível).

Não é raro, então, encontrar doutrina que tenha notado similaridade dessa questão com o problema do dolo eventual, especialmente porque o conhecimento potencial da ilicitude é a situação na qual, apesar da falta de clareza, a pessoa alcança um grau de conhecimento da situação ilícita suficiente para respaldar a atribuição de responsabilidade penal plena. ${ }^{232}$ Neste particular Felip i Saborit esclarece que "no direito alemão se denomina bedingtesUnrechtbewußtsein - literalmente 'consciência condicionada do injusto' - em claro paralelismo com o bedingterVorsatz o dolo eventual. Parece então acertada a expressão 'conhecimento ou consciência potencial da antijuridicidade' utilizada por parte da doutrina espanhola. "233

\footnotetext{
${ }^{230}$ MAYER, Max Ernst. Derecho penal: parte general. Traducción por Sergio Politoff Lifschitz. Buenos Aires; Montevidéu: B de F, 2007. p. 233.

${ }^{231}$ FELIP I SABORIT, David. La delimitación del conocimiento de la antijuricidad: una aportación al estudio del error de prohibición, cit., p. 146.

${ }^{232}$ MIR PUIG, Santiago. Derecho penal: parte general. 4. ed. Barcelona: PPU, 1996, lec. 21, n. 5; SILVA SÁNCHEZ, Jesús-María. Sobre el conocimiento eventual de la antijuricidad. Anuario de Derecho Penal y Ciencias Penales - ADPCP, Madrid, jun. 1987; PÉREZ ALONSO, Esteban Juan. La duda sobre la prohibición: especial consideración de la jurisprudência del Tribunal Supremo. Anuário de Derecho Penal y Ciencias Penales, ADPCP, Madrid, v. 48, n. 1, p. 71, ene./abr. 1995.

${ }^{23}$ Tradução livre de trecho da obra: FELIP I SABORIT, David. op. cit., p. 146.
} 
Quanto a isso, pode-se afirmar que há algum consenso de que o conhecimento da ilicitude não se resume à certeza, e que neste conceito encontram-se situações nas quais o autor não está certo do caráter proibido de sua conduta. ${ }^{234}$ Desta maneira, os casos de dúvidas ou conhecimento potencial, juntamente com a certeza, integram o conceito de conhecimento da ilicitude como situação psicologicamente oposta ao erro e merecedora de atribuição plena de culpabilidade. ${ }^{235}$

No entanto, surgem divergências quando se pretende definir o limite entre o conhecimento da ilicitude e o erro de proibição reproduzindo-se, numa escala menor, os debates quanto ao dolo eventual e a culpa consciente. ${ }^{236}$

\subsubsection{A potencialidade ou eventualidade do conhecimento}

Para determinar quando existe o conhecimento da ilicitude, a maioria dos autores se vale das fórmulas que normalmente são usadas para esclarecer seus entendimentos quanto ao dolo eventual. Assim, é comum entender-se que basta que a pessoa "considere seriamente a ilicitude de seu comportamento e saiba da possibilidade de violação ao direito" 237 para o conhecimento restar configurado. Por isso, Felip i Saborit assevera que à definição de conhecimento da ilicitude são trasladadas as diferentes fórmulas que, em matéria de dolo, expressam a presença de elementos volitivos junto aos cognoscivos, como é o caso dos termos "não confiar em", “conformar-se com”, “decidiu em favor de". 238

Considerando-se as ponderações acima, nota-se que parece haver um incremento dos defensores de um conhecimento da ilicitude puramente cognosciva, isto é, aquele composto pela mera representação da possível (ou provável) ilicitude do fato, independentemente de qualquer fator emocional ou volitivo. ${ }^{239}$ Esta tese decorre logicamente dos estudos daqueles que mantêm uma concepção exclusivamente cognitiva do dolo. Todavia, não se pode deixar de anotar que, independentemente da noção de dolo que se queira sustentar, a problemática envolvendo o conhecimento da ilicitude é distinta

\footnotetext{
${ }^{234}$ FELIP I SABORIT, David. op. cit., p. 148.

${ }^{235}$ Id., loc. cit.

${ }^{236}$ Id., loc. cit.

${ }^{237}$ JESCHECK, Hans-Heinrich; WEIGEND, Thomas. Tratado de derecho penal: parte general. 5. ed., cit., p. 489.

${ }^{238}$ FELIP I SABORIT, David. op. cit., p. 148.

${ }^{239}$ Confira-se, com amplas referências, SILVA SÁNCHEZ, Jesús-María. Observaciones sobre el conocimiento eventual de la antijuridicidad. Anuario de Derecho Penal y Ciencias Penales, Madrid, v. 40, n. 3, p. 650-652, sept./dic. 1987. Vide, ademais, PÉREZ ALONSO, Esteban Juan. op. cit., p. 76 e ss.
} 
daquela atinente ao referido elemento subjetivo. Tem-se, então, que se o caso é de quantificar o acesso de alguém ao conteúdo de uma norma como fato motivacional a se ter em conta para atribuir ou reprovar uma conduta delitiva do autor, a questão, então, é basicamente um problema de conhecimento e não de vontade. ${ }^{240}$

De qualquer forma, não parece que essas abordagens do problema, na prática, tenham resultado em diferenças significativas na determinação dos casos em que o conhecimento psicológico da ilicitude existe. Teoricamente, a presença de um elemento volitivo inserido no conceito de conhecimento da ilicitude deveria gerar consequências práticas na aferição da sua existência ou não (situação de erro), se comparado com a aplicação de um conceito puramente cognitivo.

Por outro lado, a existência do elemento volitivo no conceito de conhecimento da ilicitude faria com que não se encerrassem os questionamentos pela simples constatação da existência do conhecimento da proibição, sendo-lhe, ainda, exigida, atuação dirigida àquele conhecimento. ${ }^{241}$ Note-se, no entanto, que isso permitiria um reforço nas situações de reprovação, isto é, as deficiências quanto ao conhecimento da ilicitude poderiam ser supridas, de alguma forma, pela conduta praticada. ${ }^{242}$

No entanto, parece não haver grandes consequências desta disparidade de posicionamentos. Parece que o elemento volitivo foi uma consequência inerente à decisão de realizar a conduta típica com um determinado grau de conhecimento da ilicitude do fato.

Vista desta forma, a questão principal no estabelecimento da existência do conhecimento potencial da ilicitude ficará reduzida à fixação do grau de conhecimento (a partir do qual se pode afirmar o dito conhecimento). ${ }^{243}$

Neste sentido, embora aparentemente se tratem dos mesmos critérios para a definição do dolo eventual, todas as vezes em que houver dúvida quanto à (i)licitude da conduta então resolver-se-á pela ilicitude. De forma contrária, as situações de desconhecimento da ilicitude serão definidas pela aplicação de uma fórmula negativa, como, por exemplo, a de que somente haverá erro quando se estiver absolutamente seguro

\footnotetext{
${ }^{240}$ SILVA SÁNCHEZ, Jesús-María. Observaciones sobre el conocimiento eventual de la antijuridicidad, cit., p. 651.

${ }^{241}$ FELIP I SABORIT, David. op. cit., p. 150.

${ }^{242}$ Id., loc. cit.

${ }^{243}$ Id., loc. cit.
} 
de que o fato não é proibido. ${ }^{244}$ Então, poder-se-ia resumir a ideia na seguinte assertiva: nos casos de dúvida, deve-se abster do comportamento porque a capacidade do sujeito que duvida, desde um ponto de vista psicológico motivacional, estaria mais próxima do pleno conhecimento da ilicitude que do erro. Em última análise, aquele que vislumbra a possível existência de uma norma específica já está em condição de determinar-se pela não infringência da mesma.

Por outro lado, o entendimento de que quando houver dúvidas os casos deveriam ser regidos pelo erro de proibição seria fundamentado na ideia de que a situação não pode se equiparar ao pleno conhecimento da ilicitude, toda vez que a orientação conforme as normas jurídicas que deve facilitar o conhecimento de proibição se vê dificultada quando o sujeito não percebe com clareza a situação jurídica, com o que se aproximaria mais de um estado de erro. $^{245}$

Por seu turno, em trabalho no qual discorre sobre a dúvida quanto à ilicitude do ato, Dimakis faz interessante proposta, numa perspectiva estritamente psicológica, restringindo o conceito de conhecimento da ilicitude. Neste sentido, insiste na necessidade de distinguir claramente na análise da problemática da consciência da ilicitude uma primeira fase, de determinação do estado psíquico (constatação do conhecimento ou de sua ausência) e, uma segunda fase, representada pela posterior valoração daquele estado, no qual se determina o conteúdo de culpabilidade do fato. ${ }^{246}$

O posicionamento de Dimakis merece atenção. Em termos mais concretos, pode-se resumir seu posicionamento da seguinte forma: o autor da conduta reputada ilícita deve valorar seu próprio agir, isto é, apenas quando o autor tiver valorado todas as possibilidades e tiver chegado a uma conclusão definitiva quanto ao fato é que se poderá falar em conhecimento da ilicitude ou em erro de proibição. ${ }^{247}$ Deste entendimento decorre que, em alguns casos, não haverá de se falar em dúvida, porquanto o juízo pessoal do autor levará a uma certeza. Todavia, se durante o processo as dúvidas não são superadas, a valoração pessoal acabará em juízo de probabilidade, em cujo caso o decisivo será qual é a

\footnotetext{
${ }^{244}$ SILVA SÁNCHEZ, Jesús-María. Observaciones sobre el conocimiento eventual de la antijuridicidad, cit., p. 652-654.

${ }^{245}$ Vide FELIP I SABORIT, David. op. cit., p. 151-152.

${ }^{246}$ DIMAKIS, Alexandros. Der Zweifelan der Rechtswidrigkeit der Tat. Berlin: Dunker \& Hublot, 1992, p. 104-107 apud FELIP I SABORIT, David. op. cit., p. 150.

${ }^{247}$ DIMAKIS, Alexandros. Der Zweifelan der Rechtswidrigkeit der Tat. Berlin: Dunker \& Hublot, 1992, p. 110 apud FELIP I SABORIT, David. op. cit., p. 150.
} 
probabilidade preponderante segundo o autor. ${ }^{248}$ Apenas quando o sujeito chegar à conclusão de que a ilicitude do fato é a probabilidade dominante é que se poderá falar de uma consciência do ilícito. Por outro lado, se o autor considerar mais provável a licitude do fato, atuará sem consciência do ilícito. Finalmente, em caso de não poder chegar-se a uma conclusão, a um estado de dúvida definitivo, tampouco existirá conhecimento da ilicitude, pelo que deveria ser aplicado o tratamento do erro de proibição. ${ }^{249}$

Disso pode-se concluir que quando se equiparam a dúvida e a certeza, verifica-se uma identificação normativa de estados psicológicos objetivamente distintos que podem apresentar semelhanças. A dúvida sobre a ilicitude pode ter, então, força motivacional ainda mais intensa que a ignorância. Todavia, deve-se atentar que, a seguir este entendimento, pode-se acabar confundindo as fronteiras psicológicas do (des) conhecimento com as normativas da evitabilidade do erro. Nestes termos, enquanto alguém tenha dúvida sobre a ilicitude, não haverá de se falar propriamente de conhecimento e tampouco de erro.

Fato é que, a despeito dos posicionamentos acima aludidos, somente se poderá chegar a uma conclusão adequada caso se leve em conta que, de qualquer forma, na doutrina se propugna um tratamento especial para certos casos de dúvida, as chamadas dúvidas insuperáveis ou irresolúveis. ${ }^{250} \mathrm{E}$ isto restará exposto e demonstrado neste trabalho oportunamente.

\subsubsection{A atualidade do conhecimento da ilicitude}

Felip i Saborit assevera que atualmente há consenso de que um dos requisitos da consciência da ilicitude é o estado de atualidade deste elemento. ${ }^{251}$ Desta forma, exige-se que o autor de uma conduta tipificada tenha efetivamente o conhecimento do ilícito no

\footnotetext{
${ }^{248}$ DIMAKIS, Alexandros. Der Zweifelan der Rechtswidrigkeit der Tat. Berlin: Dunker \& Hublot, 1992, p. 110 apud FELIP I SABORIT, David. op. cit., p. 150.

${ }^{249}$ DIMAKIS, Alexandros. Der Zweifelan der Rechtswidrigkeit der Tat. Berlin: Dunker \& Hublot, 1992, p. 110 apud FELIP I SABORIT, David. op. cit., p. 150.

${ }^{250}$ FELIP I SABORIT, David. op. cit., p. 154.

${ }^{251}$ Id. Ibid., p. 176.
} 
exato momento da prática e justifica sua afirmação inclusive citando o $§ 17$ do Código Penal alemão. ${ }^{252}$

Nesse sentido, assevera-se que a questão quanto à consciência da ilicitude não deve ser encarada como uma etapa verificável num processo de reflexão sobre o fato no particular instante da prática de uma ação ou omissão que encerre uma perfeita representação da mesma. Até mesmo porque, em alguns casos, como o de crimes cometidos em situações de ímpeto essa tal etapa de reflexão provavelmente não se mostraria presente. Ainda sob essa óptica, não se trata de que o autor de uma conduta se mostrasse pensativo em saber que o que faz é ilícito, mas lhe bastaria que houvesse um saber implícito que, de alguma forma incidisse no comportamento do autor. ${ }^{253}$

Sobre as estruturas psicológicas utilizadas para solucionar problemas no âmbito do dolo verificou-se o uso do termo "co-consciência",254 do injusto para apontar o limite mínimo da atualidade dele próprio. ${ }^{255}$ Significaria, então, fazer menção aos conhecimentos internalizados pelo sujeito ao largo da sua vivência social, isto é, algo como se ter absorvido o caráter indesejado do grupo central das condutas delitivas que incidem no comportamento do sujeito no preciso momento da prática de uma conduta sem que se mostrasse preciso recorrer à sua memória ou manifestações explícitas.

Os mencionados conhecimentos - diz-se - se unem muito intensamente à consciência do sujeito de tal forma que sua conduta se mostra direcionada por estes tais fatores "co-conscientes". ${ }^{256}$ E, nesses casos nem se cogita de que tenha havido reflexão, haja vista ser a ilicitude do fato associada àquela percepção da situação.

Noutra óptica, o estabelecimento de limites de consciência da ilicitude, a partir das teorias da culpabilidade, tem importância menos efusiva do que ao tempo em que estavam

\footnotetext{
${ }^{252}$ Como se pode observar na redação a seguir exposta, "§ 17. Error de prohibición. Sí le falta al autor en la comisión de un hecho la comprensión de lo injusto de su actuar entonces actúa sin culpa si el no pudo evitar ese error. Si el autor pudo evitar el error, entonces puede atenuarse la pena conforme al $\S 49$, inciso 1." Texto extraído da tradução de LÓPEZ DIAZ, Claudia (Trad.). Código Penal Alemán del 15 de mayo de 1871, con la última reforma del 31 de enero de 1998. Bogotá: Universidad Externado de Colômbia, 1999.

${ }^{253}$ FELIP I SABORIT, David. op. cit., p. 176.

${ }^{254}$ VENTURA PÜSCHEL, Arturo. Sobre el conocimiento de algunos elementos del tipo en los delitos especiales. PJ, (2b), p. 161-178, 1993.

${ }^{255}$ MAR DÍAZ PITA, Madel. El dolo eventual. Valencia: Tirant lo Blanch, 1994. p. 58-66; VENTURA PÜSCHEL, Arturo. op. cit., p. 168-173; MUÑOZ CONDE, Francisco. El error en derecho penal. Valencia, Tirant lo Blanch, 1989. [Capítulo I publicado también en "La creencia errónea de estar obrando lícitamente", Estudios Penales y Criminológicos, Santiago de Compostela, v. 10, p. 1.040 y ss., 1987; capítulo II en "El error en el delito de defraudación tributaria del art. 349 del Código", $A D P C P$, p. 379 y ss., 1986.; capítulo III en "Bases para una teoría del error orientado a las consecuencias". La Ley, v. 1, p. 1040-1052, 1991.

${ }^{256}$ FELIP I SABORIT, David. op. cit., p. 177.
} 
em voga as teorias do dolo e, a partir de então, defenderam-se noções de consciência atual muito rigorosas. ${ }^{257}$ É bem verdade que atualmente a questão perdeu intensidade por causa da inexistência de divergências entre as teorias mencionadas por aceitar-se noções mais amplas da consciência atual da ilicitude para a determinação de um grau mínimo de motivação, a partir do qual se pode afastar o erro de proibição. ${ }^{258}$

No entanto, isso não representa a única força argumentativa do que fora acima exposto. Isto é, enquanto se possa afirmar que a consciência da ilicitude é um dado psicológico constatável, a discussão se mantém em parâmetros menos polêmicos, em especial quanto à plena culpabilidade de quem atua irreflexivamente.

Ainda assim, Jakobs defende que continuam existindo situações em que não se produz - ou em que não se faça prova eficaz - da mínima presença da consciência da ilicitude. ${ }^{259}$ Para tanto, mencionam-se casos que envolvem estados passionais e outros delitos cometidos sob a égide da habitualidade como os maus-tratos familiares, injúrias e rufianismo. $^{260}$

Felip i Saborit discorre, ainda, que se mostra problemática a afirmação do conhecimento atual da ilicitude quando a situação envolve anomalias ou alterações psíquicas ou certos estados passionais. Tais situações podem não ter exatamente os requisitos legais para a exclusão ou atenuação da imputabilidade e chegam a impedir que se esteja presente o conhecimento da ilicitude sequer co-conscientemente. ${ }^{261}$

Também se assevera que, considerando os casos acima mencionados, um erro de proibição por falta da consciência atual é algo bastante factível, mas igualmente mostra-se um indício de que a pessoa não responderia por seus atos devido a um estado de inimputabilidade. E, justamente para evitar que se alterem os limites legais de exclusão da imputabilidade é que Rudolphi propõe que quando os elementos que levam ao impedimento da atualização do conhecimento da ilicitude têm uma única causa de alterações psíquicas vinculadas às causas de inimputabilidade, deve ser aplicada a regulação legal destas últimas apenas. ${ }^{262}$

\footnotetext{
${ }^{257}$ FELIP I SABORIT, David. op. cit., p. 177.

${ }^{258}$ Id. Ibid., p. 178.

${ }^{259}$ JAKOBS, Günther. Derecho penal: parte general: fundamentos y teoría de la imputación, cit., p. 651-686.

${ }^{260}$ FELIP I SABORIT, David. op. cit.

${ }^{261}$ Id. Ibid., p. 179.

262،§ 17 StGB” en RUDOLPHI, Hans-Joachim (dir.j: SK-StGB. Systematischer Kommentarzum Strafgesetzbuch. 6a ed., Neuwied, Luchterhand, 199 apud FELIP I SABORIT, David. op. cit., p. 179.
} 
Tomando em consideração o que foi exposto acima, pode-se concluir que nem todo conhecimento que alguém possa ter sobre o caráter proibido de um fato restará nesse estado latente e pronto a receber uma "ignição" assim que se apresentar a ocasião. Assim, ficariam excluídos da consciência da ilicitude os dados que não tenham surgido à mente do autor dos fatos no momento da prática delitiva. Essa situação é denominada, algumas vezes, de “consciência não atual", isto é, aquelas situações em que o conhecimento poderia ter estado aflorado na mente de uma pessoa no momento do fato, mediante alguma reflexão. ${ }^{263}$

Também é de se mencionar que, geralmente, na Espanha são aceitas teorias alemãs no intuito de solucionar questões envolvendo os níveis mínimos para que se possa estatuir que alguém continha o conhecimento no momento da prática delitiva. ${ }^{264}$ Também é preciso dizer que a questão sobre o conhecimento atual ganhou maior repercussão a partir de embates doutrinários, vinculando-se mais a temas como a atenuação obrigatória ou facultativa em situações de erro de proibição que propriamente delineamentos quanto ao conceito de ilicitude. ${ }^{265}$

No que tange à atualidade do conhecimento, talvez Bustos Ramirez tenha sido um dos maiores críticos da representação consciente. Para o autor, não há sentido em falar-se em atualidade da compreensão do ilícito, porque isto é algo que se tem ou não se tem, de forma que a atualidade não se pode demonstrar especialmente no processo penal e na maioria dos delitos culposos. ${ }^{266}$

\subsubsection{Conhecimento atual, potencial e eventual}

O problema do conhecimento atual da ilicitude merece que se façam comentários, ainda que mais conceituais que práticos. Inobstante, o interesse pelo tema pode surgir em

\footnotetext{
${ }^{263}$ FELIP I SABORIT, David. op. cit., p. 179.

${ }^{264}$ SILVA SÁNCHEZ, Jesús-María. Sobre el conocimiento eventual de la antijuricidad, cit., p. 657; COBO DEL ROSAL, Manuel; VIVES ANTÓN, Tomá S. Derecho penal: parte general. 4. ed. (adecuada al Código penal de 1995 por María Isabel Valldecabres Ortiz). Valencia: Tirant lo Blanch, 1996. p. 602; GRACIA MARTÍN, Luis. Política criminal y dogmática jurídico penal del proceso de reforma penal en España (y II). APen, n. 2, p. 376, 1994.

${ }^{265}$ MIR PUIG, Santiago. Derecho penal: parte general. 4. ed., cit.; GRACIA MARTÍN, Luis. op. cit., p. 376.

${ }^{266}$ BUSTOS RAMIREZ, Juan. El tratamiento del error en la reforma de 1983: art. 6 bis a. Anuário de Derecho Penal y Ciencias Penales, ADPCP, t. 38, n. 3, p. 715, sept./dic. 1985; HUERTA TOCILDO, Susana. Problemática del error sobre los presupuestos de hecho de una causa de justificación. CDJ, v. 18/20, p. 249-275, 1993. (El consentimiento. El error).
} 
virtude de situações confusas ou, ainda, por originar certas tendências. ${ }^{267} \mathrm{E}$, sob esta perspectiva é que a questão do conhecimento atual foi historicamente um mecanismo da teoria finalista para tentar pôr em xeque a teoria do dolo. De modo geral, a exigência da consciência efetiva da ilicitude para a atribuição de responsabilidade dolosa suporia remeter todos os casos de erro de proibição à imprudência, com todos os problemas e lacunas que isto implicaria. ${ }^{268}$

Quanto a esse posicionamento, já se conhece bem a proposta do finalismo, isto é, a de que para a verificação da culpabilidade bastaria a possibilidade de conhecimento da ilicitude, o que alguns autores vieram a denominar "potencial consciência"269 e, consequentemente, se o conhecimento atual concreto deixava de condicionar o caráter doloso do delito, então restaram superadas as lacunas de incriminação imprudente. No entanto, isso não impediu que cessasse a distinção, com base na sua natureza física diferente, entre os conhecimentos atual e potencial. ${ }^{270}$ Maurach, quanto a isso, dizia que o erro de proibição podia, mas não devia necessariamente atenuar a culpabilidade. ${ }^{271}$

Assim, o conhecimento potencial criava dificuldades em que fosse mantida a distinção sobre a base de sua diferente natureza psíquica, entre o conhecimento atual da ilicitude e o conhecimento potencial ou o que é o mesmo, o erro de proibição evitáveli, ${ }^{272}$ com efeito, neste segundo caso, de quantificar o grau concreto de culpabilidade. Toda vez que, como se reconhecia abertamente, o erro de proibição evitável podia, mas não devia necessariamente, atenuar a culpabilidade. ${ }^{273}$

Felip i Saborit afirma, quanto a isso, que "a partir dessa premissa, a questão do conhecimento atual era utilizada em aspectos concretos da crítica à teoria do dolo. Se, segundo esta, o conhecimento dos elementos que conformam o tipo e o conhecimento da ilicitude deviam integrar um mesmo elemento, o dolusmalus, por coerência interna ambos os fatores deviam ser psicologicamente uniformes, isto é, o sujeito deveria ser consciente da ilicitude do fato da mesma maneira que percebia e se representava o suposto fato típico". ${ }^{274}$

\footnotetext{
${ }^{267}$ FELIP I SABORIT, David. op. cit., p. 180.

${ }^{268}$ Id. Ibid., p. 181.

${ }^{269}$ MAURACH, Reinhart. Tratado de derecho penal. Trad. 2. ed. (1958) y notas de Derecho español por Juan Córdoba Roda. Barcelona: Ariel, 1963. p. 135 e ss.

${ }^{270}$ Id. Ibid., p. 148.

${ }^{271}$ Id. Ibid., p. 146-148.

${ }^{272}$ Id. Ibid., p. 148.

${ }^{273}$ Id. Ibid., p. 146-148.

${ }^{274}$ FELIP I SABORIT, David. op. cit., p. 181.
} 
Desta forma, a representação da ilicitude sempre foi objetada pelo finalismo, porque não era verificável em delitos imbuídos de caráter passional ou mesmo cometidos com habitualidade, pelo que o que se podia conceber como ficções quanto ao estado de consciência de alguém, sendo punições graves apenas aplicadas a título de culpa. ${ }^{275}$ Mesmo assim, ainda que se pudesse falar da ausência de consciência da ilicitude, esta não seria apta a livrar alguém da prática de uma conduta típica, restando ainda a reprovabilidade.

E, no que tange ao finalismo, deve-se dizer que Welzel propiciou enfoque diferente para a questão da atualidade do conhecimento, mencionando seu caráter de atualização, isto é, considerando-o atualizável e promovendo diferenciações entre o conhecimento da ilicitude e seu desconhecimento ou erro de proibição. ${ }^{276}$ Quanto à consciência da ilicitude, defendia a ideia de que isto era formado por situações de conhecimento efetivo ou atual e, outra, como a da não atualidade dessa consciência. Em outras palavras, importa dizer que, por exemplo, quanto aos delitos praticados mediante situações de ímpeto, não haveria consciência da ilicitude como representação, mas apenas como um conhecimento não atual. ${ }^{277}$ Também, quando nem sequer se possuísse esse conhecimento, mas, de outra forma, tivesse sido possível sua aquisição, estaríamos diante de um erro de proibição evitável. $^{278}$

Acrescentou ainda, Welzel, que as situações acima apresentadas - a consciência da ilicitude, o conhecimento não atual e, ainda, a possibilidade de ter tal conhecimento, teriam um elemento comum entre si: a reprovabilidade, diferenciando-se, no entanto, em graus. Assim, às duas primeiras se imporia a máxima reprovação sob o argumento de que quanto mais fácil a autodeterminação do sujeito, a reprovação deveria ter grau mais elevado. ${ }^{279}$ Quanto ao erro, a reprovação poderia ser diminuída conforme a evitabilidade do mesmo. ${ }^{280}$

Também se deve dizer que os estudos que surgiram ainda na década de 60 e que ofereceram fundamento psicológico à ampliação da consciência ou conhecimento atual da ilicitude até situações de conhecimento irreflexivo foram rechaçados por Welzel. ${ }^{281}$

\footnotetext{
${ }^{275}$ WELZEL. Hans. El nuevo sistema de derecho penal: una introducción a la doctrina de la acción finalista. Versión castellana y notas por José Cerezo Mir. Barcelona: Ariel, 1964.

${ }^{276}$ Id. Ibid., p. 106 e 112-114.

${ }^{277}$ Id. Ibid., p. 112.

${ }^{278}$ Id., loc. cit.

${ }^{279}$ Id., loc. cit.

${ }^{280}$ Id., loc. cit.

${ }^{281}$ Id. Derecho penal alemán. Trad. de la 11. ed., cit., p. 227.
} 
Ainda é de se considerar que em razão da consolidação da teoria da culpabilidade do Código Penal Alemão à época, fez-se com que as questões sobre o problema do conhecimento atualizável tenham perdido alguma importância, havendo certo consenso, naquele país, quanto a um novo conceito psiquicamente unitário de consciência ou conhecimento da ilicitude. ${ }^{282}$ Nesse sentido, é correta a ideia de que a teoria da culpabilidade fez substituir o conhecimento atual pelo potencial, uma vez que a possibilidade tomou lugar da efetividade na função sistemática de pressuposto mínimo de culpabilidade por condutas dolosas. Todavia, se diz que isso não significa que tenha havido uma substituição completa de conceitos, uma vez que o conhecimento atual ainda se mostra uma espécie de referência em oposição ao qual se elabora dogmaticamente o erro de proibição. ${ }^{283}$

Eis aqui, então, o motivo da digressão quanto a isso, haja vista que as considerações de Welzel no sentido de haver esta figura intermediária (psicológico-normativa) do conhecimento não atual - um meio-termo entre a consciência e o erro - poderia acabar por confundir as situações havidas entre a consciência potencial e efetiva. ${ }^{284}$

Por isso se diz que não seria correto o uso do conceito de conhecimento potencial da ilicitude como uma forma especial de existência da consciência de ilicitude, a menos que significasse a ausência evitável do ilícito. ${ }^{285}$ Assim, a doutrina alemã, ao discorrer sobre a problemática do conhecimento eventual da ilicitude, o faz sob o aspecto da atualidade, não sobre o da potencialidade. ${ }^{286}$

Também é verdade que no âmbito do dolo os termos "conhecimento potencial" e "não atual" são utilizados indistintamente e que, frequentemente há o emprego do termo "conhecimento potencial da ilicitude" para esclarecer que todo erro de proibição representa um estado psicológico. Por isso, Felip i Saborit conclui e defende que é aconselhável manter a terminologia e as definições do conhecimento não atual no âmbito de um estado psicológico do conhecimento entre a consciência e a falta de consciência, sem vinculá-lo imediatamente ao erro evitável (conhecimento potencial) nem utilizá-lo como sinônimo deste. ${ }^{287}$

\footnotetext{
${ }^{282}$ FELIP I SABORIT, David. op. cit., p. 184.

${ }^{283}$ Id. Ibid., p. 185.

${ }^{284}$ Id., loc. cit.

${ }^{285}$ Nesse sentido, ESER, Albin; Bjorn BURKHARDT. Derecho penal: cuestiones fundamentales de la Teoría del Delito sobre la base de casos de sentencias, cit., § 14, num. 57.

${ }^{286}$ MAURACH, Reinhart. op. cit., p. 159. Vide, ainda: PÉREZ ALONSO, Esteban Juan. La duda sobre la prohibición: especial consideración de la jurisprudência del Tribunal Supremo, cit., p. 71 e ss; MIR PUIG, Santiago. Derecho penal: parte general. 4. ed., cit., lec. 21, n. 5.

${ }^{287}$ FELIP I SABORIT, David. op. cit., p. 186.
} 
Quanto à realidade brasileira, pode-se apontar que consta do item 17 da Exposição de Motivos do Código Penal algumas breves considerações sobre o potencial conhecimento da ilicitude, in verbis:

"17. É, todavia, no tratamento do erro que o princípio nullum crimen sine culpa vai aflorar com todo o vigor no direito legislado brasileiro. Com efeito, acolhe o Projeto, nos arts. 20 e 21, as duas formas básicas de erro construídas pela dogmática alemã: erro sobre elementos do tipo (Tatbestandsirrtum) e o erro sobre a ilicitude do fato (Verbotsirrtum). Definiu-se a evitabilidade do erro em função da consciência potencial da ilicitude (parágrafo único do art. 21), mantendo-se no tocante às descriminantes putativas a tradição brasileira, que admite a forma culposa, em sintonia com a denominada 'teoria limitada da culpabilidade'. '(Culpabilidade e a problemática do erro jurídico penal', de Francisco de Assis Toledo, in RT 517/251)."

Ademais, verifica-se, abaixo o que dispõe literalmente o art. 21 do Código Penal:

"Erro sobre a ilicitude do fato

Art. 21. O desconhecimento da lei é inescusável. O erro sobre a ilicitude do fato, se inevitável, isenta de pena; se evitável, poderá diminuí-la de um sexto a um terço.

Parágrafo único. Considera-se evitável o erro se o agente atua ou se omite sem a consciência da ilicitude do fato, quando lhe era possível, nas circunstâncias, ter ou atingir essa consciência."

Nota-se, portanto, que o ordenamento jurídico pátrio foi estruturado pensando-se numa potencial consciência da ilicitude. Esta, por seu turno, pode-se relacionar com o erro de proibição sob três distintas modalidades, as quais serão oportunamente analisadas no Capítulo específico sobre o erro.

\subsection{O objeto do conhecimento da ilicitude}

Uma das primeiras coisas a se fazer para que se possa analisar a contento o conhecimento da ilicitude é estudar a delimitação do que se pode entender por estar agindo ilicitamente. Em outras palavras, significa compreender e apontar o que é ignorado pelo agente autor de uma conduta para que se possa afirmar que desconhecia o ilícito.

Para que se chegue a essa conclusão, no entanto, faz-se necessário fixar o objeto do conhecimento da ilicitude. É importante frisar que, para as violações mais comuns ocorridas em sociedade, como um homicídio, um furto ou roubo, é mais fácil a percepção 
do que se mostra incompatível com a boa convivência social. Isto é, a contrario sensu, é de se imaginar que, afastando-se justamente desses comportamentos empiricamente ditos como ilícitos em qualquer parte do mundo, será um tanto quanto menos provável que as pessoas saibam realizar um prognóstico correspondente ao que a lei considera permitido ou proibido.

Assim, quando as pessoas se deparam com situações menos óbvias do que matar ou subtrair patrimônio alheio, poder-se-á enfrentar questionamentos sobre o que se "sente" proibido ou permitido. É o que mais facilmente se pode verificar em casos em que não se tem sensação de ilicitude ao manterem-se relações sexuais com menor de 14 anos ou, ainda, na aquisição ou venda de medicamento sem autorização das autoridades sanitárias competentes. Nesses casos a representação do que pode ser uma violação ética ou social relevante para o direito penal torna-se mais complexa.

Também é importante frisar que, ao mesmo tempo que se possa ter alguma ideia do que possa representar um ilícito administrativo, tributário, civil ou trabalhista, não é de se imaginar que as pessoas deixarão de cometê-lo por saberem disso. Ao menos não em um ordenamento jurídico que não permite que suas normas tenham efeito motivador sobre as pessoas.

Por outro lado, tem-se a noção de que a exigência de um conhecimento técnico jurídico da ilicitude - ainda que desejável - é de alcance pouquíssimo provável pela população em geral. Aí é que se entra na discussão sobre quais são ou devem ser os requisitos mínimos para que se possa dizer que alguém tem recebido influência suficiente do ordenamento jurídico que lhe faça atuar conforme o direito. Seria o caso de fazer ponderação sobre o que dá sustentação à orientação da lei em cada indivíduo e, ainda, substrato para que as normas jurídicas sejam respeitadas.

No Brasil, aparentemente o objeto do conhecimento da ilicitude não é tão discutido, ao contrário de outros países, onde há debates sobre a necessidade de qualificar a consciência. E, entre nós, há até quem tenha percebido a problemática, já se pensando num viés funcionalista na observação das questões que envolvem essa temática. Fato é que se entende que para que se atribua uma prática delitiva a alguém basta que a pessoa tenha agido diante de uma "potencial consciência" do ilícito. Esse também é o entendimento majoritário na Alemanha.

Em uma aproximação mais cética quanto à temática proposta, seria possível até mesmo entender que os questionamentos quanto ao objeto do conhecimento do ilícito 
tornam a discussão estéril haja vista que, observado na prática, usualmente tais diferenças não deveriam permitir repercussões que ensejassem preocupações excessivas, especialmente porque os pilares estão profundamente reclusos nas mentes de quem conhece ou desconhece a proibição, algo de demonstração fática pouco provável, senão impossível.

Pensando-se noutra perspectiva, a discussão tem sentido e nos remete justamente à questão de que, quanto mais nos afastamos de um direito penal nuclear, somos obrigados a recorrer aos recursos pessoais de modo que conhecer as normas jurídicas passam, paradoxalmente, a ser algo importante para que se possa ter um conhecimento, ao menos parcial do que sejam condutas ilícitas. Todavia, é fundamental considerar que, muito além de discutir-se o conhecimento do ilícito no âmbito processual, como prova, está intimamente relacionado como marco determinante na vencibilidade dos erros.

Afirma-se que há unanimidade em reconhecer-se a insuficiência do conhecimento do autor sobre a violação de princípios ético-sociais ou morais reinantes na sociedade com sua conduta. Isso não se mostra uma imposição para que sejam formuladas proibições jurídicas. Isto porque as pessoas, em geral, têm dificuldades para identificar o que pode representar normas éticas, sociais e jurídicas. Auxilia a incrementar essa confusão o pluralismo ideológico das sociedades contemporâneas, com influências de grupos específicos, como os gestores atípicos da moral. Importante é ter em mente que, a despeito de que se possa considerar uma das missões do direito penal a de evitar comportamentos lesivos, não serão todos eles que deverão se ver proibidos pela lei penal.

Por outro lado, apesar da subjetividade que isso possa envolver, seria o caso de considerar o objeto do conhecimento da ilicitude um ponto referencial da inadmissibilidade do erro, porque com toda a situação expansiva do direito penal, não seria absurdo - como de fato não é - ponderar que certas situações podem levar um indivíduo a atuar certo de que o faz sem violação às leis penais, ainda que se possa ter algum conhecimento da imoralidade de seu comportamento. Exemplo clássico é o do homem que tem relações sexuais com menor de idade, sabendo-o imoral, mas desconhecendo a ilegalidade penal quanto a isso.

O objeto da consciência da ilicitude é grande motivo de controvérsias e, em países como o Brasil e a Alemanha, o entendimento é no sentido de que, para que se possa imputar o fato a alguém será bastante que a mesma tenha o conhecimento potencial da ilicitude. 
As divergências sobre o objeto do conhecimento da ilicitude podem, aparentemente, soar um tanto despidas de validez prática, porque normalmente não haveria repercussões tão significativas devido à dificuldade em fazer prova quanto a isso e, ainda, porque é difícil que suas nuances estejam claramente presentes na mente de cada pessoa. Ademais, deve-se considerar que o tema ganha importância à medida que se afasta de um Direito Penal nuclear, sendo certo que as pessoas cada vez menos podem se valer dos conhecimentos próprios, sendo crucial que recorram a peculiaridades técnico-jurídicas das normas, o que favorece a existência de conhecimento matizado. Deve-se ter em mente que o objeto da consciência da ilicitude não significa apenas algo a ser provado no processo, mas um verdadeiro ponto de referência para a determinação da vencibilidade do erro. Eis a importância de verificá-lo. 


\section{O FENÔMENO DA EXPANSÃO DO DIREITO PENAL}

\subsection{Ponderações iniciais}

Uma das discussões mais vivas na dogmática penal das últimas décadas é aquela relativa ao direito penal moderno e sua legitimidade, suas características e desejável evolução ou mesmo desaparecimento. Trata-se de tema que sabidamente não guarda posicionamento pacífico, verificando-se importantes discussões doutrinárias também em países como Alemanha, Itália e Espanha.

A inexistência de consenso se dá porque há uma notória e até mesmo radical divisão entre os críticos da modernização do Direito Penal e, de outro lado, de seus fervorosos partidários. Também porque, além da dicotomia acima citada, comporta posicionamentos diversos em cada uma das vertentes. Assim, afirma-se encontrar finalistas favoráveis e contra a modernização, bem como funcionalistas igualmente adotando entendimentos distintos. ${ }^{288}$ Além disso, por não serem encontrados muitos resultados práticos dela advindos, parece que tais debates ainda não se encontram maduros o suficiente.

Todavia, parece haver certo consenso nas últimas décadas que, sob a óptica político-criminal, o direito penal mostra-se a forma mais grave de intervenção do Estado diante do indivíduo, o que justificaria restrições a essa ingerência. ${ }^{289}$ Tal concepção, somada à latente crise do pensamento ressocializador, promoveu o surgimento de propostas como as puramente abolicionistas e as reducionistas do sistema penal. ${ }^{290}$ Propostas estas que, além de buscarem alternativas à pena privativa de liberdade, focam também na despenalização e abolição de tipos penais, em franca oposição à tendência expansionista do Direito Penal contemporâneo.Verifica-se, pois, que o debate sobre a

\footnotetext{
${ }^{288}$ PAREDES CASTAÑÓN, José M. Recensión: GRACIA MARTÍN, Luis. Prolegómenos para la lucha por la modernización y expansión del derecho penal y para la crítica del discurso de resistência." Política Criminal, v. 1, n. 2, p. 1, dic. 2006.

${ }^{289}$ CRESPO, Eduardo Demetrio. Do direito penal liberal ao direito penal do inimigo. Revista de Ciências Penais, São Paulo, n. 1, p. 9-37, dez. 2004.

${ }^{290}$ Sobre a evolução, vide CRESPO, Eduardo Demetrio. Prevención general e individualización judicial de la pena. Prólogos de Ignácio Berdugo e Hans Joachim Hirsch. Salamanca: Universidad de Salamanca, 1999. p. 51 et seq., 58 et seq. (Acta salmanticensia estudios jurídicos, 79).
} 
legitimidade do Direito Penal ${ }^{291}$ pode ser resumido, atualmente, ao binômio "reducionismo versus expansão", isto é, com o debate focado no contexto e exigências do que se convencionou denominar "modernização do direito penal".

Fato é que o debate sobre a idoneidade do direito penal no âmbito da discussão político-criminal e dogmática acerca da expansão do direito penal na sociedade de riscos gerou diversas manifestações, como a de Prittwitz, que diz que assistirmos há tempos a uma irritante discordância entre o programático de um direito penal submetido a limites e o dia a dia de uma criminalização crescente, coisa intolerável em um momento no qual se reconhece sabidamente a "incapacidade" do direito penal para solucionar certos tipos de problemas. $^{292}$

Justamente neste ponto é que importa ponderar se o direito penal se encontra numa situação insustentável que demanda mudanças de caráter expansionista, ou, pelo contrário, se está diante de uma nova situação que, todavia, não justifica as tais alterações no sistema. Por isso é que se entende adequado percorrer, ainda que brevemente, sobre as ideologias favoráveis e contrárias à modernidade penal nas quais se consubstancia a expansão, apresentando-se, abaixo, os principais discursos envolvendo a questão. Não se pode esquecer, no entanto - que a despeito da existência de vozes contrárias a uma expansão penal, defendendo-se a manutenção ou redução do sistema a um direito penal mínimo - já não se pode negar que o fenômeno integra a realidade de muitos países, dentre os quais o Brasil, o que será demonstrado oportunamente neste trabalho.

Por ora, segue-se apresentando os discursos favoráveis e contrários à expansão.

\subsubsection{Em defesa da expansão penal}

Os debates sobre a necessidade da modernização do direito penal, reconhecendo-se na expansão algo como indissociável da realidade das sociedades contemporâneas, são

\footnotetext{
${ }^{291}$ É muito ilustrativa, do ponto de vista global, a seguinte obra recentemente publicada: BERGALLI, Roberto (Coord.). Sistema penal y problemas sociales. Valencia: Tirant lo Blanch, 2003. passim; e, em especial, no que aqui nos interessa, com uma perspectiva histórico-sociológica, cf. RIVERA BEIRAS, Iñaki. Historia e legitimación del castigo. Hacia dónde vamos? In: BERGALLI, Roberto (Coord.). Sistema penal y problemas sociales, cit., p. 86 et seq.

${ }^{292}$ PRITTWITZ, Cornelius. El derecho penal alemán: ¿fragmentario? ¿subsidiario? ¿ultima ratio? Reflexiones sobre la razón y límites de los principios limitadores del derecho penal. Trad. por María Teresa Castiñeira. In: INSTITUTO DE CIENCIAS CRIMINALES DE FRANKFURT (Ed.). La insostenible situación del derecho penal. Granada: Comares, 2000. p. 427 et seq.
} 
promovidos, como se disse, em oposição ao pensamento partidário do direito penal mínimo. São adeptos à modernização do direito penal autores como Luis Gracia Martín, Berd Schunemann e Lothar Kuhlen, dentre outros, que defendem nova fundamentação filosófica e novas metodologias de modo a se passar para o outro lado do discurso jurídico penal. $^{293}$

Uma das primeiras pontuações que se faz neste sentido é a de que o Direito Penal deve corresponder às exigências materiais da ordem social de modo que o ramo penal não se torne epistemologicamente inaceitável e politicamente reacionário. ${ }^{294}$ Assim, Gracia Martín propõe a construção de um novo discurso baseado em uma crítica dogmáticofilosófica, cuja pretensão derradeira seria interpretar os conceitos e os princípios jurídicopenais no contexto do materialismo da História, o que nas suas palavras denominou "perspectiva histórico-material". ${ }^{295}$

Destarte defende-se a ideia de que o Direito Penal será realmente moderno quando alcançar harmonia com o momento histórico da sociedade, sendo certo que sua dissonância deste patamar torná-lo-á reacionário e irracional. ${ }^{296} \mathrm{E}$, neste sentido a história mostra que o conceito de modernidade tem sido empregado para registrar transições, momentos históricos que certamente não ocorrem repentinamente, mas gradativamente. Afinal, o que é moderno hoje, deixará de sê-lo no futuro. Desta forma, a modernização penal acaba sendo imposta pela história: a transformação social, seja no plano material, seja no intelectual, obriga que se defenda a modernização com vistas à preservação da verdadeira racionalidade do discurso jurídico-penal.

\subsubsection{Sobre as teses contrárias à expansão: o discurso de resistência e as críticas da Escola de Frankfurt}

Dentre os posicionamentos atuais sobre os possíveis direcionamentos da política criminal verifica-se uma vertente que defende a necessidade de que a intervenção punitiva

\footnotetext{
${ }^{293}$ GRACIA MARTÍN, Luis. Prolegómenos para la lucha por la modernización y expansión del derecho penal y para la crítica del discurso de resistencia. Valencia: Tirant lo Blanch, 2003. p. 218. Apresentação de Bernd Schünemann.

${ }^{294}$ Id. Ibid., p. 52.

${ }^{295}$ Id. Ibid., p. 199.

${ }^{296}$ PAREDES CASTAÑÓN, José M. op. cit., p. 5.
} 
seja focada em um Direito Penal mínimo. ${ }^{297}$ Neste sentido inserem-se as propostas da chamada Escola de Frankfurt, cujos expoentes são autores como Hassemer, Pritwitz, Herzog, Naucke e Muñoz Conde, dentre outros.

Adotada esta concepção, afirma-se que a modernização enfaticamente defendida por certos autores ${ }^{298}$ diante do que se convencionou chamar de "discurso da resistência", compreende construções como o Direito Penal do inimigo ${ }^{299}$ - que pretende despojar da categoria de cidadãos determinados sujeitos, que devem ser tratados como meras fontes de perigo, devendo ser neutralizados a qualquer preço ${ }^{300}$ - diante do qual cabe a ponderação se modernização representa uma real evolução, ou o contrário, uma lamentável involução.

A concepção que rechaça a ampliação do direito penal parte da premissa de que ele deve ser muitíssimo limitado, com incidência apenas sobre condutas agressivamente violadoras de bens jurídicos considerados essenciais para a vida em sociedade, como a vida e o patrimônio. Por isso, Hassemer entende que a tentativa de reduzir a insegurança da sociedade de riscos promove significativas alterações na dogmática penal, afastando-o da sua missão primordial, que no seu entender é o asseguramento de uma escala de valores indispensáveis à vida social. $\mathrm{O}$ afastamento da missão inicial faz do direito penal um instrumento de busca pelo controle de grandes problemas da sociedade atual. ${ }^{301}$

\footnotetext{
${ }^{297}$ Sobre o tema, vide: PASCHOAL, Janaína Conceição. Constituição, criminalização e direito penal mínimo. São Paulo: Ed. Revista dos Tribunais, 2003.

${ }^{298}$ GRACIA MARTÍN, Luis. Prolegómenos para la lucha por la modernización y expansión del derecho penal y para la crítica del discurso de resistencia, cit., passim.

${ }^{299}$ JAKOBS, Günther. Estudios de derecho penal. Trad. Enrique Peñarada Ramos, Carlos Soárez González e Manuel Cancio Meliá. Madrid: Civitas, 1997. p. 294 et seq.; JAKOBS, Günther; CANCIO MELIÁ, Manuel. Derecho penal del enemigo. Trad. Manuel Cancio Meliá. Madrid: Civitas, 2003. passim. CRESPO, Marcelo Xavier de Freitas. Direito penal do inimigo: sobre o que estamos falando? Boletim IBCCRIM, São Paulo, ano 16, n. 196, p. 3, mar. 2009.

${ }^{300}$ Sobre essa questão, vide CANCIO MELIÁ, Manuel. Derecho penal del enemigo y delitos de terrorismo: algunas consideraciones sobre la regulación de las infracciones en materia de terrorismo en el Código Penal (LGL 194012) español después de la Lei Orgânica 7/2000. Derecho Penal Contemporáneo, Revista Internacional, v. 3, 2003; PORTILLA CONTRERAS, Guillermo. El derecho penal y procesal del enemigo: las viejas y nuevas políticas de seguridad frente a los peligros internos-externos. In: LÓPEZ BARJA DE QUIROGA, Jacobo; ZUGARLDÍA ESPINAR, José Miguel (Eds.). Dogmática y ley penal: libro homenaje a Enrique Bacigalupo. Madrid: Instituto Universitario de Investigación Ortega Y Gasset; Marcial Pons, 2004 (inédito); el mismo, La legislación de lucha contra las no-personas: represión legal del 'enemigo' tras el atentado del 11 de septiembre de 2001. Mientras Tanto, n. 83, p. 77-91, 2002; do mesmo modo, fazendo referência, em um lúcido trabalho sobre o estado atual da ciência penal na Espanha, à formulação de "fundamentos e metas do direito penal abertamente regressivos, como é o direito penal 'de inimigos' patrocinado por G. Jakobs e outros”, vide QUINTERO OLIVARES, Gonzalo. La deriva y crisis de las ideas penales y de la política criminal en España: libro homenaje a Ruiz Antón. Universidad de Extremadura, 2004. (inédito).

${ }^{301}$ BOTTINI, Pierpaolo Cruz. Crimes de perigo abstrato e princípio da precaução na sociedade de risco. São Paulo: Ed. Revista dos Tribunais, 2007. p. 98.
} 
De fato, pode-se falar que há algum consenso por parte da doutrina sobre alguns pontos da discussão do atual estágio do Direito Penal. Assim, fala-se num Direito Penal do Risco (ou da prevenção) além de discutir-se sua efetividade e legitimidade, tudo com vistas à legitimidade de se perseguir um incremento de efetividade por meio de um modelo preventivo ou de risco. ${ }^{302}$

Em face do exposto, verifica-se haver uma vertente que pretende defender bens jurídicos que detenham caráter individualista, cabendo ao Direito Penal, neste caso, reprimir a violação destes bens de forma subsidiária e mediante a aplicação de princípios e regras tradicionalmente destinados à imputação de responsabilidade aos indivíduos. Para a defesa desta vertente alega-se haver diferentes razões para negar a adequação do Direito Penal para resolver os problemas típicos da tutela difusa. ${ }^{303}$

Uma destas razões é a assessoriedade administrativa. Explica-se: o Direito Penal não atua de forma autônoma, sendo - em alguma parte - dependente do Direito Administrativo, transformando-se num instrumento auxiliar da Administração Pública. Para Hassemer, a assessoriedade torna o ilícito menos evidente para a sociedade, restando a ilicitude penal menos óbvia e fazendo com que o Direito Penal perca alguma credibilidade perante a sociedade. ${ }^{304}$

Outra razão refere-se diretamente à imposição de penas privativas de liberdade, que fazem com que o Direito Penal se atenha a critérios individuais de imputação de responsabilidade, inerentes ao direito penal clássico.

A terceira razão relaciona-se com o reconhecimento de que no Direito Penal de proteção a interesses difusos promove uma ilusão quanto à função geral positiva, sendo esta finalidade inatingível.

Também se pode apontar como razão ser o direito penal de proteção a interesses difusos puramente simbólico, isto é, não protege efetivamente os bens jurídicos, representando mero instrumento para a consecução de fins políticos. E isto pode auxiliar que os poderes públicos se desobriguem quanto à perseguição de uma política pública efetiva.

\footnotetext{
${ }^{302}$ PRITTWITZ, Cornelius. Strafrecht und Risiko. Apud MENDOZA BUERGO, Blanca. El derecho penal em la sociedad del riesgo. Madrid: Editora Civitas, 2001. p. 66.

${ }^{303}$ Especialmente quanto à inadequação para tutela ambiental, vide: HASSEMER, Winfried. A preservação do ambiente por meio do direito penal. Conferência ministrada na Universidade Lusíada - Porto, no âmbito do I Congresso Internacional de Direito do Ambiente, com tradução simultânea do alemão por Carlos Eduardo Vasconcelos, adaptada para publicação por Paulo de Sousa Mendes. Notícias do Direito Brasileiro, nova série, UNB, n. 4, p. 92, 2. sem. 1997.

${ }^{304}$ HASSEMER, Winfried. Derecho penal simbólico y protección de bienes juridicos. Pena y Estado, Barcelona, n. 1, p. 34, 1991.
} 
Esta concepção, como se pode observar, pretende afastar o Direito Penal da missão de gerir riscos, limitando-o à proteção aos ataques mais violentos que sejam direcionados aos bens jurídicos.

Verifica-se, pois, que as críticas são no sentido de que o uso do Direito Penal para as demandas da sociedade de risco provoca algo como uma erosão do Direito Penal garantista no Estado de Direito, afastando-o da condição de instrumento utilizado como ultima ratio. ${ }^{305}$ Até mesmo por isso se diz que esse uso do ramo penal torna visível um lado perverso da regulamentação estatal, consubstanciando-se num expediente para que o Estado faça frente a problemas sociais de grande envergadura. ${ }^{306}$

Ao contrário, o Direito Penal funcional há de se fazer compatível com uma vocação mais restritiva possível da intervenção punitiva. Trata-se da proteção penal das expectativas essenciais cuja desproteção penal daria lugar a reações disfuncionais e, na medida em que exista o risco de que elas ocorram. Desse modo, é coerente a defesa do Direito Penal funcional.

Na posição diametralmente oposta encontra-se a proposta de flexibilização dos instrumentos dogmáticos e das regras de atribuições de responsabilidades, a fim de que o Direito Penal angarie condições para atuar na proteção aos bens jurídicos supraindividuais e no controle dos novos fenômenos do risco, já que nesta concepção ele é a condição de estabilidade da sociedade do risco, posição esta desenvolvida neste trabalho.

\subsection{Sobre algumas causas da expansão penal}

Apesar das mencionadas vozes contrárias à expansão penal trata-se o fenômeno de realidade visivelmente constatada em nossa sociedade, pelo que urge comentar algumas das causas apontadas como responsáveis pela sua existência.

\footnotetext{
${ }^{305}$ MÜLLER-TUCKFELD, Jean Christian. Ensayo para la abolición del derecho penal del medio ambiente. In: INSTITUTO DE CIENCIAS CRIMINALES DE FRANKFURT (Ed.). La insostenible situación del derecho penal. Granada: Comares, 2007. p. 507-549. Vide, ainda, MACHADO, Marta Rodriguez de Assis. Sociedade de risco e direito penal: uma avaliação de novas tendências político-criminais. São Paulo: IBCCRIM, 2005. p. 190. (Monografias/IBCCRIM; 34).

${ }^{306}$ GIACOMO, Roberta Catarina; MACHADO, Fábio Guedes de Paula. Novas teses dogmáticas jurídicopenais para a proteção do bem jurídico ecológico na sociedade do risco. Revista Liberdades, v. 2, p. 39-55, 2009. Os autores até mesmo dizem que "O Direito Penal não pode se converter em 'porta-bandeira' das demandas sociais mais conjunturais, superficiais ou meramente verbalizadas".
} 
Insta frisar que a possível confusão existente entre as causas com os sintomas presta-se apenas a difundir a equivocada noção de que a contenção da criminalidade darse-á eficazmente pela intervenção penal. Isto faz com que, de forma contraproducente, sejam atacadas as conseqüências do problema, deixando sem solução suas verdadeiras causas.

Ademais, diz-se comentar algumas das causas porque não é razoável enumerá-las taxativamente tendo-se em vista que a expansão penal é resultado de diversas situações, passíveis de serem observadas sob diferentes óticas, como o surgimento de novos riscos e a institucionalização do sentimento de insegurança, por exemplo. Lembra-se que será em face desse estudo que se poderão estabelecer diretrizes políticas e sociais adequadas a serem aplicadas no desenvolvimento da sociedade contemporânea.

Seguem, então, algumas das causas da expansão penal.

\subsubsection{Algumas palavras sobre os medos e as inseguranças sociais}

Há, basicamente, dois caminhos a se seguir quando se pensa em Direito Penal: o de se entender e reconhecer que há bens jurídicos que merecem proteção legal; e o de se entender que não há bens jurídicos a serem protegidos na vida em sociedade, considerando-se que o Direito Penal busca apenas e tão somente a reafirmação das normas. Obviamente, entre essa dicotomia haverá posicionamentos mais ou menos radicais, mais flexíveis ou menos elásticos, mas, em resumo, eis uma ideia fundamental a se ter em consideração. Não que essa ideia venha a ser o mecanismo que pode se tornar a suprema solução dos problemas que serão apresentados no decorrer deste trabalho, mas ainda assim, é uma ideia que deverá ser tomada como importante.

Ao mesmo tempo, é de se considerar, ainda, que o reconhecimento da existência de bens jurídicos, portanto de interesses que devam ser protegidos por lei, pode ser e será interpretado como algo que justificará, em muitos casos, a tipificação de infrações penais que, aparentemente, não estarão aptas a proteger a sociedade senão imprimir limitações à tão desejada liberdade tida como direito fundamental em nossa Constituição.

Assim, será importante ter em conta a percepção de realidades que antes não eram verificadas ou, pelo menos, não se apresentavam na intensidade notada em tempos 
atuais. ${ }^{307}$ Apesar da doutrina já ter se ocupado de tratar desses interesses, especialmente os de caráter difuso, não se pode afirmar que haja consenso sobre os limites de sua proteção. $^{308}$

Fato é que, com base nos estudos de Ulrich Beck convencionou-se dizer que deixamos de viver em uma sociedade clássica para sermos inseridos em uma sociedade de risco, isto é, uma vivência social permeada por avanços derivados da tecnologia que trazem significativa melhora na vida das pessoas. ${ }^{309}$ Obviamente não se pode deixar de considerar que as benesses tecnológicas trazem, de forma ínsita, os chamados riscos estruturais, ou seja, aqueles aos quais estamos todos expostos por causa de tomadas de decisões de outras pessoas, especialmente quando manejam tais inovações tecnológicas. São exemplos as comunicações feitas por meios informáticos, a energia nuclear, a biologia, a genética, entre outras.

Outra situação a ser ponderada é o surgimento de tipos penais, agora vistos sob perspectiva não apenas do dolo direto, mas das falhas técnicas, situações nas quais se admite que, em alguma proporção, haverá acidentes em virtude da complexidade das relações sociais advindas do desenvolvimento técnico. ${ }^{310}$ Isso torna a sociedade atual uma expressão da insegurança, de modo que não se podem conhecer precisamente os efeitos negativos, que até mesmo poderão passar despercebidos tempos depois da conduta.

A questão transmuta-se para uma discussão sobre a divisão dos riscos, não sobre sua geração, dada a imensa gama de condutas que podem ser interpretadas como geradoras de riscos. Nesse sentido, perdem a aparente eficiência os crimes de resultado, restando o ramo penal diuturnamente acrescido de tipos penais de perigo, especialmente o presumido. ${ }^{311}$ Torna-se, assim, definitiva a noção de complexidade social, já comentada por autores como Roxin, na qual são desconhecidos os níveis de interação social. ${ }^{312} \mathrm{Em}$

\footnotetext{
${ }^{307}$ SILVA SÁNCHEZ, Jesús-María. A expansão do direito penal: aspectos da política criminal nas sociedades pós-industriais. 2. ed. São Paulo: Ed. Revista dos Tribunais, 2010. p. 33.

${ }^{308}$ ALEXY, Robert. El concepto y la validez del derecho. Barcelona: Editorial Gedisa, 1994. p. 179 e ss.

${ }^{309}$ Especificamente sobre a tecnologia, vide o nosso Crimes digitais. São Paulo: Saraiva, 2011. Para uma abordagem mais sucinta sobre o pensamento de Beck, vide BECK, Ulrich. De la sociedad industrial a la sociedad del riesgo. Revista de Occidente, n. 150, p. 19, nov. 1993.

${ }^{310}$ SILVA SÁNCHEZ, Jesús-María. A expansão do direito penal: aspectos da política criminal nas sociedades pós-industriais, cit., p. 37.

${ }^{311}$ Neste sentido, vide LOPES CEREZO, José Antônio; LÓPEZ LUJÁN, José Luis. Ciencia y politica del riesgo. Madrid: Alianza, 2000. Vide, ainda, BOTTINI, Pierpaolo Cruz. op. cit.

${ }^{312}$ Cf. ROXIN, Claus. El desarollo del derecho penal e el seguinte siglo. In: política criminal. Trad. Manuel Abanto Vasquez. Lima: Idemsa, 1998. p. 435 e ss. Dogmática penal y
} 
outras palavras, a dinâmica das camadas de organização pessoal possibilita que os contatos sociais dela advindos possam gerar lesões.

Noutra perspectiva, os delitos de resultado deixam de fazer sentido, porque não se mostram tecnicamente aptos a tratar dessa complexidade, recorrendo-se, constantemente, às tipificações de perigo - concreto e abstrato - e outras tantas a situações que sequer se vislumbra o perigo. ${ }^{313}$

O fato é que passa a existir uma interdependência nas relações pessoais porque há muito mais comportamentos de terceiros voltados ao controle de riscos do que antigamente. ${ }^{314}$ Há, portanto, maior dependência dos comportamentos de outras pessoas para que controlem os riscos, de modo que se chega a cogitar a modalidade culposa como novo paradigma do conceito de delito. ${ }^{315}$

Diz-se, ainda, que a sociedade pós-industrial é a que vive verdadeira crise quanto ao que se entende pelo welfare state, havendo altos índices de desemprego, choques culturais, criminalidade de rua, sendo essa outra dimensão da sociedade de risco, ${ }^{316}$ preocupação essa que também justificou movimentos como o denominado "lei e ordem", que se arraigaram com mais amplitude no bojo social.

Passa, assim, a existir um sentimento generalizado de insegurança, que nas palavras de Silva Sánchez representa a sociedade da "insegurança sentida" ou "sociedade do medo". Isso não significa dizer que situações novas, geradoras de riscos antes não imaginados, não existam. Pelo contrário. Tanto tecnológicas quanto não tecnológicas passaram a fazer parte da sociedade, até por causa da enxurrada de informações cada vez mais disponibilizada às pessoas e, também pela inexistência de critérios que apontem seguramente situações admitidas como boas ou ruins. ${ }^{317}$ E Silva Sánchez exemplifica a ideia acima com três situações. Em primeiro lugar, entende o autor que está mais difícil a adaptação das pessoas

\footnotetext{
${ }^{313}$ BOTTINI, Pierpaolo Cruz. op. cit.

${ }^{314}$ Note-se que, aqui, não se está discutindo ser a sociedade atual mais ou menos perigosa que outras, passadas. A questão é que percebem-se com mais frequência os riscos que permeiam a sociedade. O professor Vicente Greco Filho, por exemplo, usualmente refuta a máxima de que vivemos em "sociedade de risco mais perigosa que no passado", valendo-se do argumento de que hoje, apesar destes riscos advindos da complexidade, a expectativa de vida e a média de vida de cada um de nós é maior que no passado.

${ }^{315}$ SILVA SÁNCHEZ, Jesús-María. A expansão do direito penal: aspectos da política criminal nas sociedades pós-industriais, cit., p. 37. Vide, ainda, GUNTHER, Klaus. De la vulneración de um derecho a la infracción de um deber. Un "cambio de paradigma en el derecho penal?. In: INSTITUTO DE CIENCIAS CRIMINALES DE FRANKFURT (Ed.). La insostenible situación del derecho penal. Granada: Comares, 2000. p. 489. Conferir esta nota.

${ }^{316}$ SILVA SÁNCHEZ, Jesús-María. A expansão do direito penal: aspectos da política criminal nas sociedades pós-industriais, cit., p. 40.

${ }^{317}$ Id. Ibid., p. 41.
} 
na sociedade decorrente da manifesta aceleração do ritmo de vida, especialmente pelo incremento das comunicações. ${ }^{318}$ Esse incremento causa a sensação de falta de domínio quanto aos acontecimentos. Em segundo lugar, há dificuldades em se reconhecer uma informação digna de confiança. ${ }^{319}$ Por fim, a aceleração é algo da vida, não somente relativo à tecnologia, de modo que há uma urgência por estarmos sempre à disposição. ${ }^{320}$

Todo o conjunto de fatores acima apontados causa, além da angústia e incerteza, obscuridade, confusão e até mesmo a chamada "perplexidade da relatividade", termo usado por Smart, que pretende representar a perda de referências valorativas. ${ }^{321}$

Todo esse fenômeno reportado nas linhas acima tem, ainda, o agravante de que a crise de complexidade não diz respeito somente a novos riscos e noções de convivência, mas também especialmente porque a falta das referências valorativas citadas impõe a resolução de questões de cunho ético-filosóficas. Assim, não se distinguindo o que sejam informações fidedignas, se abre a oportunidade para que a força seja o divisor de águas, o poderoso balizador, mantendo-se a insegurança. Falta substrato para buscar um consenso social sobre o que é certo e errado também porque desapareceram as estruturas de solidariedade tradicionalmente vislumbradas por ocasião da convivência familiar. ${ }^{322}$ Essa falta de solidariedade estruturalmente considerada torna a interesses individualmente considerados, verificando-se um conjunto de pessoas que, apesar de reunidas em sociedade, são isoladas por suas buscas de satisfação pessoal, desmaterializando o que se entende por comunidade. ${ }^{323}$

De qualquer forma, não se pode apontar cientificamente que a insegurança vivida pelos cidadãos remeta sua origem exatamente na existência de riscos (in) controláveis. Até

\footnotetext{
${ }^{318}$ CRESPO, Marcelo Xavier de Freitas. Crimes digitais, cit.

${ }^{319}$ Ponto de vista: KANITZ, Stephen. Cuidado com o que ouvem. Veja, São Paulo, ed. 2028, 03 out. 2007. Disponível em: <http://veja.abril.com.br/031007/ponto_de_vista.shtml>. Acesso em: 09 maio 2012.

${ }^{320}$ Nesse sentido, SILVA SÁNCHEZ, Jesús-María. A expansão do direito penal: aspectos da política criminal nas sociedades pós-industriais, cit., p. 42. Cf. ainda, MARINA, José Antonio. Crónicas de la ultramodernidad. Barcelona: Anagrama, 2000. p. 100.

${ }^{321}$ SMART, Barry. Post modernity. London; New York: Routledge, 1993. p. 111.

${ }^{322}$ SILVA SÁNCHEZ, Jesús-María. A expansão do direito penal: aspectos da política criminal nas sociedades pós-industriais, cit., p. 44. Vide, ainda, LLEDÓ REAL, Pilar. La inseguridad como causa del racismo y la xenofobia. Revista Catalana de Seguridad Publica, n. 2, p. 21, abr. 1998. E, ainda, PILAR Lledó Real. Disponível em: <www.pilarlledo.es>.

${ }^{323}$ SOUZA, Maria de Lourdes. La individualización post moderna. Anuário de Filosofia del Derecho, p. 321, 1999.
} 
porque também é de se considerar que mesmo havendo surgimento de novos riscos, há certa compensação, os contrarriscos, especialmente quanto a perigos naturais. ${ }^{324}$

Diz-se, ademais, que há extrema "sensibilidade ao risco", de modo que nossa ideia quanto a eles é superior ao que realmente podem representar, ${ }^{325}$ até mesmo pela disseminação dos meios de comunicação. É a influência, também, da sociedade da informação, impondo sua(s) imagem(ns) da realidade ${ }^{326}$ e, ainda, o sentimento pessoal de querer controlar tudo o que está em nossa volta, incluindo-se aí o futuro. ${ }^{327}$

Também se afirma que a "mass media", muitas vezes, transmite uma versão da realidade que acaba iludindo a audiência. ${ }^{328}$ Não se questiona aqui a boa ou má-fé nas transmissões, o fato é que há algum desencontro entre o que se apresenta pela mídia e o que se pode vivenciar pessoalmente, o que pode levar - e leva - à formação de sentimentos baseados em percepções, se não equivocadas, pelo menos inexatas. Nesse ponto, Reiner já destacava que as formas pelas quais os meios de comunicação transmitem notícias afastam-nos da realidade por causa da atenção desproporcional dada a certos assuntos. ${ }^{329}$ Veja-se, neste sentido, que o Superior Tribunal de Justiça chegou a emitir uma nota institucional de esclarecimentos à sociedade relativamente à recente decisão proferida pela Terceira Seção daquele tribunal que decidiu que a presunção de violência no crime de estupro tem caráter relativo e pode ser afastada diante da realidade concreta. ${ }^{330}$

Esse tipo de abordagem, além de gerar a sensação de nada se poder fazer quanto aos fatos, impõe reiteradas passagens sobre o mesmo acontecimento, quase como um

\footnotetext{
${ }^{324}$ SILVA SÁNCHEZ, Jesús-María. A expansão do direito penal: aspectos da política criminal nas sociedades pós-industriais, cit., p. 46.

${ }^{325}$ MARINA, José Antonio. op. cit., p. 147. Importante passagem da obra aponta que "estamos educando nossos jovens com um baixo nível de tolerância à frustração. Todos nós convertemos com facilidade em propagandistas da recompensa imediata".

${ }^{326}$ Sobre a sociedade de informação, vide o nosso Crimes digitais, cit. Para a influência da mídia no medo das pessoas, vide BARATA, Francesc. Las nuevas fabricas del miedo: los "mass media" y la inseguridad ciudadana. In: MUÑAGORRI, Ignacio (Ed.). La protección de la seguridad ciudadana. Oñate: Instituto Internacional de Sociología jurídica de Oñate, 1995. p. 83. (Oñati Proceedings, n. 18).

${ }^{327}$ Para abordagem específica sobre o tema, vide: WATKINS, Tony. Faking it: the sentimentalization of modern society. London: The Social Affair is Unit, 1998.

${ }^{328}$ SILVA SÁNCHEZ, Jesús-María. A expansão do direito penal: aspectos da política criminal nas sociedades pós-industriais, cit., p. 46-48.

${ }^{329}$ REINER, Robert. Media made criminality: the representation of crime in the mass media. In: MAGUIRE, Mike; MORGAN, Rod; REINER, Robert (Eds.). Oxford Handbook of criminology. 2. ed. Oxford: Oxford University Press, 1997. p. 189 e ss. Entre nós, vide: FERRARI, Eduardo Reale; PASCHOAL, Janaina Conceição. Ficção x realidade: um pequeno ensaio sobre a otimização de políticas de segurança. Boletim IBCCRIM, São Paulo, v. 9, n. 107, p. 13-14, out. 2001.

${ }^{330}$ A decisão diz respeito ao artigo 224 do Código Penal, revogado em 2009. A nota pode ser lida em SUPERIOR TRIBUNAL DE JUSTIÇA. Esclarecimentos à sociedade. Disponível em: $<$ http://www.stj.jus.br/portal_stj/publicacao/engine.wsp?tmp.area=398\&tmp.texto=105290>. Acesso em: 06 abr. 2012.
} 
instrumento multiplicador de desgraças, de modo que a percepção de insegurança de cada um de nós encontra-se em dissonância com o perigo objetivamente considerado. Silva Sánchez bem expõe em duas situações como a "mass media" trata certas questões que acabam por deturpar nossas percepções. Num primeiro caso cita o episódio de um criminoso sexual que ganhou muito destaque na mídia por seus ataques, tendo sido preso e condenado e, quando da sua libertação, noticiou-se "não tinha dado sinais de arrependimento" e que tampouco havia "se submetido a tratamento". $331 \mathrm{Com}$ isso, quis demonstrar que mesmo não sendo o tipo de situação corriqueira, a mídia tratou da questão de forma que pudesse amedrontar a sociedade. Por outro lado, aponta no segundo episódio, que o contrário também pode ocorrer. E, para isso, menciona que embora haja dados oficiais da ONU sobre homicídios de forma a verificar-se que no Brasil há cerca de 60 vezes mais homicídios por grupo de 100.000 pessoas que na Espanha, esse tipo de morte no país é tratado pela mídia como "problema mundial". ${ }^{332}$

Ocorre, porém, que nem sempre essas sensações de insegurança têm seu nascedouro na mídia. Pelo contrário, já se diz que o próprio Estado se presta a transmitir de forma pouco clara a realidade, contribuindo para a disseminação da insegurança. ${ }^{333}$ Não se deseja, por outro lado, fixar uma constatação de que os medos são gerados única e exclusivamente pela mídia ou por fontes oficiais, porque já se nota que é fato que eles reforçam, intensificam sentimentos difusos inerentes ao convívio em sociedade atualmente. ${ }^{334}$ De fato, diz-se que o medo de crimes representa uma metáfora da insegurança vital generalizada. ${ }^{335}$

Um dos principais problemas baseados no medo difuso é o anseio social por respostas do Estado, especialmente por alterações no Direito, mais pontualmente ainda, quanto ao Direito Penal. Problema, porque somando isso às manifestações populistas dos governos e, ainda, a discursos populistas fazem incrementar a sensação de que é o Direito Penal a suprema solução de todas as mazelas sociais. Deixam de considerar que não será só por meio da criação de tipos penais, do incremento de penas, de regras processuais mais rigorosas, que se terá a tranquilidade e a paz de espírito almejadas. Até porque Prittwitz já

\footnotetext{
${ }^{331}$ SILVA SÁNCHEZ, Jesús-María. A expansão do direito penal: aspectos da política criminal nas sociedades pós-industriais, cit., p. 46-48, nota 44.

${ }^{332}$ Id. Ibid., p. 48-49.

${ }^{333}$ Vide CHAMBLISS, William J.; BAER, Justin. Generating fear: the politics of crime reporting. Crime Law and Social Change, v. 27, n. 3, p. 87 e ss., 1997.

${ }^{334}$ SILVA SÁNCHEZ, Jesús-María. A expansão do direito penal: aspectos da política criminal nas sociedades pós-industriais, cit., p. 50.

${ }^{335}$ Id. Ibid. Vide, ainda, IMBERT, Gerard. Los escenarios de la violencia. Barcelona: Icaria, 1992. p. 43.
} 
havia apontado que, apesar de os homens viverem seguros como nunca antes na história, o medo e a insegurança tornaram-se no tema do século $\mathrm{XX},{ }^{336}$ justificando alterações nas garantias fundamentais por serem entendidas como excessivamente protetoras de “criminosos". Por essas razões é que se nota que a busca pelas soluções deixam de passar por outros ramos do direito, pela atuação prática das autoridades oficiais, dando azo para que se queira intervir diretamente no direito penal, quebrando-se a importante característica da ultima ratio, muito defendida pela doutrina em geral, mas pouco vista na prática.

Silva Sánchez pondera que a falta de orientação já relatada acima, sobre o que é bom ou ruim, é cada vez maior, de forma que há uma constante busca por tais referências. Essa procura passa justamente pelo Direito Penal, ramo que se pretende referenciar, ocupando lugar de destaque em uma sociedade que prescinde de valores positivos, na busca pelo consenso. ${ }^{337}$

\subsubsection{Algumas consequências do medo e da insegurança}

Já se disse que há cada vez mais pessoas beneficiárias da transferência do que propriamente criadoras das riquezas uma vez que a concentração de capital faz com que as classes empreendedoras sejam menos numerosas. ${ }^{338}$ Nesse sentido, sua importância e seu prestígio já não se mostram os mesmos vislumbrados no passado recente. Isso tem importante ligação com o modelo de concentração econômica gerado pela globalização, trazendo à tona a noção de risco permitido como patamar limitador de ingerência nas liberdades individuais, ao menos no campo doutrinário.

A ideia de risco permitido resvala na máxima de que a sociedade deverá arcar com o ônus do desenvolvimento considerando-se que, para que haja um padrão adequado de qualidade, necessariamente é preciso, num primeiro momento, haver acúmulo de capital. ${ }^{339}$

\footnotetext{
${ }^{336}$ PRITTWITZ, Cornelius. Strafrecht und Risiko. Untersuchhungenzur Krise von Strafrecht und Kriminalpolitik in der Risikogesellschaft. Frankfurt, 1993, p. 73 apud SILVA SÁNCHEZ, Jesús-María. A expansão do direito penal: aspectos da política criminal nas sociedades pós-industriais, cit., p. 51.

${ }^{337}$ SILVA SÁNCHEZ, Jesús-María. A expansão do direito penal: aspectos da política criminal nas sociedades pós-industriais, cit., p. 52.

${ }^{338}$ Id., loc. cit.

${ }^{339}$ BISBAL MÉNDEZ, Joaquim. La responsabilidad extracontractual y la distribución de los costes del progreso. Revista de Derecho Mercantil, n. 167/168, 1983. Aqui é feito um estudo paralelo das teorias da culpa civil entre os séculos XIX e XX, nos Estados Unidos, e o desenvolvimento industrial.
} 
Em outras palavras, para que a congregação de capital seja suficiente para passar a ser empregado também na proteção social, haverá um momento antecedente no qual haverá alguns resultados lesivos. Isto significa que o debate, ou pelo menos as ideias que permearam a pós-industrialização, tem robusto ponto de toque com retrocesso do risco permitido, isto é, pondera-se readequação do que seja um risco permitido. ${ }^{340}$

O risco permitido envolve a ponderação de vantagens e desvantagens numa ética consequencialista sobre determinadas condutas, devendo, ainda, passar por valoração prévia considerando-se os interesses preferenciais notados em sociedade. ${ }^{341} \mathrm{E}$ deve-se ponderar, ademais, que as mudanças sociais nas últimas décadas, somadas à sobrevalorização da segurança, fizeram com que os patamares de permissão do risco fossem repensados porquanto se inserem em âmbito de conflito de liberdades muitas vezes perigosas. Essa é uma das características de sociedades em que os agentes concentradores de riquezas estão em minoria.

O que se deseja colocar como fundo da discussão é que nos encontramos em situação de restrição de atuação, claramente ampliando o campo de ação individual. E isso não é tudo, uma vez que se passa a notar certa resistência aos chamados acontecimentos fortuitos. $^{342} \mathrm{O}$ que de fato ocorre é que a noção de autocompreensão social ganha contornos de que toda e qualquer geração de riscos se dá com base em comportamentos humanos, seja por condutas ativas ou omissivas. ${ }^{343}$ Daí a dificuldade em admitir o fortuito justamente porque o modelo social delineado faz inserir nas vítimas a sensação de que acontecimentos lesivos não advenham normalmente das suas condutas. ${ }^{344}$ Parte-se da ideia que deve haver alguém, em algum momento, responsável pelos fatos, alguém que deva arcar com a responsabilidade penal, redundando no que se convencionou chamar de “expansão da imputação de responsabilidade".

Aqui cabe lembrar que por muito tempo se preferiu identificar os fenômenos históricos como obras da natureza, sendo que atualmente o que se pode notar, ainda que empiricamente, é uma tendência contrária: a promoção de explicações humanas para desastres naturais. Nesse contexto, explica-se que aquilo que não pode ser explicado pela

\footnotetext{
${ }^{340}$ SILVA SÁNCHEZ, Jesús-María. A expansão do direito penal: aspectos da política criminal nas sociedades pós-industriais, cit., p. 54.

${ }^{341}$ Para estudos sobre o questionamento dos valores aqui apontados, vide JAKOBS, Günther. La imputación objetiva en derecho penal. Trad. Cancio Melia. Madrid: Civitas, 1996. p. 119 e ss.

${ }^{342}$ SWAANINGEN, René van. Critical criminology: visions from europeu. London: SAGE, 1997. p. 174.

${ }^{343}$ PARDO, José Esteve. Tecnica, riesgo y derecho. Barcelona: Ariel, 1999. p. 43.

${ }^{344}$ Id. Ibid., p. 35.
} 
natureza de forma plena, então será atribuído a alguém, ainda que coletivamente (à sociedade) ou individualmente de modo que a história da humanidade tem sido, de certa forma, a tentativa de explicação pela imputação. ${ }^{345}$ Assim, a conduta humana resistiu à tentativa do positivismo em explicar as condutas sob a óptica causal, reconduzindo-a ao empirismo da psiquiatria e das ciências sociais, cuja expansão da imputação notada nas últimas décadas mostra a pretensão em se obter a todo e qualquer custo a responsabilidade de alguém, mostrando-se necessário o "valor simbólico-comunicativo da imputação". ${ }^{346}$

Isto, obviamente, tem consequências jurídicas, especialmente pelo surgimento dos delitos de perigo. Em raciocínio contrário, havendo apenas tipos penais de resultado, então a ideia incutida será a de que só haverá sanção (sentido amplo) caso haja o resultado. $\mathrm{O}$ foco da questão aqui é que o delito de perigo se pauta pela confiança social de que não haverá produção de resultado, por isso mesmo há quem entenda que sua tipificação reforça o argumento de dar robustez às expectativas sociais. ${ }^{347}$ Também por isso Silva Sánchez diz que a justificativa para os modelos típicos de perigo estão no fato de que em uma sociedade de "contatos anônimos, os meios de asseguramento cognitivos das vítimas potenciais são, simplesmente, impraticáveis...".348

\subsubsection{O aspecto vitimológico-social advindo da expansão penal}

Uma interessante característica da maior percepção dos riscos e, ainda, fruto do medo e insegurança acima retratados, é a composição da sociedade por mais vítimas. Notase a presença de mais sujeitos de classes passivas, também chamados por Gonzáles Seara de "sujeitos do bem-estar", 349 dotados de grandes expectativas relativas diante do Estado, não se vivendo mais nele, mas também, dele de modo que se tema pelas reservas que o compõem, fomentando a ideia de proteção a ele, protegendo as fragilidades individuais de

\footnotetext{
${ }^{345}$ SILVA SÁNCHEZ, Jesús-María. A expansão do direito penal: aspectos da política criminal nas sociedades pós-industriais, cit., p. 61.

${ }^{346}$ Id. Ibid., p. 62.

${ }^{347}$ Vide JAKOBS, Günther. Sociedad, norma, persona en una teoría de un derecho penal funcional. Trad. por Cancio Meliá y Bernardo Feijoó. Bogotá: Centro de Investigaciones de Derecho Penal y Filosofía del Derecho, 1996. p. 47. (Cuadernos de conferencias y artículos n. 13).

${ }^{348}$ SILVA SÁNCHEZ, Jesús-María. A expansão do direito penal: aspectos da política criminal nas sociedades pós-industriais, cit., p. 63.

${ }^{349}$ GONZÁLES SEARA, Luis. Los sujetos del bienestar. Diario ABC, 29 dez. 1997. p. 26.
} 
cada pessoa. ${ }^{350}$ Isso auxilia a promoção de alterações quanto ao jus puniendi na feliz expressão usada por Silva Sánchez de que perde espaço a situação da "espada do Estado contra o delinquente desvalido", para ganhar campo "a espada da sociedade contra a delinquência dos poderosos". 351

A concepção acima relatada, ao ser confrontada com a clássica noção de direito penal - aquela em que as leis devem respeitar a legalidade e são uma arma contra os abusos do Estado - sofre importantes alterações quando se passa a ponderar que a noção de vítima também pode ser ampliada. Em outras palavras, o que se quer dizer é que toda insegurança retratada algumas laudas antes passa a fundamentar e justificar uma reinterpretação do que possa significar o Direito Penal, deixando de ser tão voltado a garantir direitos contra os abusos estatais para também tornar-se uma espécie de proteção contra todo e qualquer risco que possa afetar as pessoas individualmente falando. ${ }^{352}$

Há, nesse contexto, a identificação social com a vítima, de forma a considerar-se a pena como mecanismo apto a reparar ou, ao menos, minimizar os efeitos sofridos por causa do delito. Constrói-se, assim, raciocínio que pretende disseminar a ideia de que, se não foi possível evitar o delito, sendo vitimado um cidadão, que se aplique uma pena ao autor. ${ }^{353}$ A pena de prisão é a que mais faz sentido nesse contexto, de modo que significa muito para a vítima, prestando a reintegrá-la num contexto de que o grupo social lhe é solidário. Diante desse quadro, é natural que surjam posicionamentos que defendam uma insurgência contra os poderosos e todos os que podem estar envolvidos com a criminalidade organizada. ${ }^{354}$

\footnotetext{
${ }^{350}$ Nesse sentido, MUÑOZ MACHADO, Santiago; GARCIA DELGADO, José Luis; GONZÁLES SEARA, Luis. (Dir.). Las estructuras del bienestar en Europa. Madrid: Escuela Libre Editorial, 2000. Vide, ainda, PALIERO, Carlo Enrico. Metodologia de lege ferenda: per una riforma non improbabile del sistema sazionatorio. Rivista Italiana di Diritto e Procedura Penale, Milano, n. 12, p. 536, 1992.

${ }^{351}$ SILVA SÁNCHEZ, Jesús-María. A expansão do direito penal: aspectos da política criminal nas sociedades pós-industriais, cit., p. 65. Vide, ainda, FRANCO, Alberto Silva. Globalização e criminalidade dos poderosos. In: PODVAL, Roberto (Coord.). Temas de direito penal econômico. São Paulo: Ed. revista dos Tribunais, 2000.

${ }^{352}$ SILVA SÁNCHEZ, Jesús-María. A expansão do direito penal: aspectos da política criminal nas sociedades pós-industriais, cit., p. 67 refere-se às Magnas Cartas do criminoso e também da vítima.

${ }^{353}$ Id. Ibid., p. 68.

${ }^{354}$ Em termos amplos: HASSEMER, Winfried. Segurança pública no Estado de Direito. Revista Brasileira de Ciências Criminais, São Paulo, v. 2, n. 5, p. 55 e ss., jan./mar. 1994; Mais especificamente sobre o tema: SÁNCHEZ GARCÍA DE PAZ, Isabel. La criminalidad organizada: aspectos penales, procesales, administrativos y policiales. Madrid: Dickinson, 2005. Vide, ainda, LEVI, Michael. Perspectives on 'organized crime': an overview. The Howard Journal of Criminal Justice, v. 37, n. 4, p. 335-345, Nov. 1998; BETTI, Stefano. New prospects for inter-state co-operation in criminal matters: the Palermo Convention. International Criminal Law Review, n. 3, p. 151-167, 2003. SYMEONIDOUKASTANIDOU, Elisabeth. Towards a new definition of organized crime in the European Union. European Journal of Crime, Criminal Law and Criminal Justice, v. 15, n. 1, p. 83-103, 2007.
} 
Passa-se a deixar de lado o indesejável rótulo da política de "lei e ordem" para se estruturar um novo tipo de pensamento: o de que o Estado é protetor, ou deve proteger dos riscos. Assim, surge nomenclatura nova, mais voltada à segurança cidadã, como ressalta Lascano. ${ }^{355}$ É uma nova espécie de reação, menos estigmatizada com nomenclaturas e rótulos pouco democráticos, mas ainda assim, passível de violação de importantes direitos e garantias fundamentais.

Ocorre que não se tem como temática principal, nos dias atuais, a criminalidade rasteira, dos menos favorecidos. ${ }^{356}$ Silva Sánchez aponta que isso pode significar um erro de perspectiva, uma vez que assevera que $80 \%$ da criminalidade moderna segue sendo composta pelos lowerclass crimes, isto é, a criminalidade dos pobres, o que acaba por fazer com que as reformas penais antigarantistas atinjam não só a criminalidade mais moderna, econômica, mas especialmente os agentes da criminalidade rasteira, grande maioria como se afirmou acima. ${ }^{357}$ Aponta-se que isso não significa que passaremos a ter uma dicotomia no tratamento penal dos poderosos e também dos marginalizados, mas certamente se verifica uma mudança que faz com que teses mais antigas, das décadas de 60 e 70, quando se falava em corresponsabilidade penal, percam espaço para teses que abracem a ideia de ética ligada à responsabilidade individual. ${ }^{358}$ Não se pode esquecer, no entanto, que essa outra concepção, que passa a se assentar nas décadas de 80 e 90, também pode incorrer em excessos, como aponta a doutrina, que nota maior abordagem na criminalidade infantojuvenil. ${ }^{359}$ Mesmo no Brasil, pode-se verificar de tempos em tempos, manifestações que buscam endurecer o tratamento dispensado aos menores infratores, muitas vezes pleiteando-se regramento equivalente ao aplicado nos adultos infratores. ${ }^{360}$

\footnotetext{
${ }^{355}$ LASCANO, Carlos Julio. La insostenible 'modernización del derecho penal' basada en la 'tolerancia cero' desde la perspectiva de los países 'emergentes'. Disponível em <http://www.defensesociale.org/revista2003/10.pdfl>. Acesso em: 08 jun. 2011.

${ }^{356}$ TIEDEMAN, Klaus. Poder económico y delito. Barcelona: Ariel, 1985. p. 27. Aqui o autor aponta que, na Alemanha, já na década de 70 se percebia a criação de promotorias especializadas em crimes econômicos.

${ }^{357}$ SILVA SÁNCHEZ, Jesús-María. A expansão do direito penal: aspectos da política criminal nas sociedades pós-industriais, cit., p. 70.

${ }^{358}$ TRUJILLO, Manuel. El fin de la great Society? ABC, 07 nov. 2000. p. 34. Disponível em: <www.abc.es>.

${ }^{359}$ PIPPER, Cristine. The crime and disorder act 1998: child and community "safety". Modern Law Review, n. 62, p. 397 e ss., 1999.

${ }^{360}$ Vide, por exemplo, o PDC 494/2011 - Projeto de Decreto Legislativo - que dispõe sobre a realização de plebiscito acerca da redução da maioridade penal para dezesseis anos de idade.
} 


\subsubsection{Sobre o descrédito de outras instâncias de proteção}

A ausência de uma ética social mínima faz com que as condutas alheias se tornem causadoras de angústias sociais. Isto porque o comportamento dos demais cidadãos passa a ser uma incógnita. ${ }^{361} \mathrm{O}$ fato é que a reconstrução social verificada nesse contexto da expansão penal parece não ter sido suficiente para que se formassem núcleos de moralização voltados à proteção de bens jurídicos. ${ }^{362}$ Assim, a sociedade civil não obteve a estrutura moral correspondente ao que demanda o direito penal, causando atuação anômala da política criminal, chamada a responder por situações que não lhe seriam do seu âmbito de atuação. ${ }^{363}$

Não à toa, ainda na década de 30, Ortega y Gasset já se manifestava sobre a escassez moral vivida na Europa, apontando que "é indiferente que se dissimule de reacionário ou de revolucionário: ativamente ou com passividade, ao cabo de umas e outras voltas, seu estado de ânimo consistirá, decisivamente, em ignorar toda obrigação e sentirse, sem que ele mesmo suspeite por que, sujeito de ilimitados direitos". ${ }^{364}$ Desta forma, há tendência em que uma conduta seja repudiada moralmente pela sociedade, mesmo não representando uma afronta ao Direito, favorecendo o incremento da violência. ${ }^{365}$

Essas mudanças traduzem não só uma inversão de valores, mas verdadeira confusão entre valores. Tal fenômeno é retratado por Marina, citando Guillebaud, que decreta ser o código penal o responsável por nortear a sociedade quando esta perde pontos de referência, se prestando a apontar o bem e o mal. ${ }^{366}$

Por outro lado, Silva Sánchez expõe dúvidas quanto à eficácia da atuação do Direito Civil diante dos desafios advindos da nova realidade social. ${ }^{367}$ Alega-se que o modelo que privilegia a objetivização da responsabilidade, delineando o ramo civil em base securitária - fundada em contratos de seguro - não está apto a exercer sua função clássica porque os danos restariam, de alguma forma, minimizados pelo seguro, o que indica que níveis de cuidado do agente seriam relativizados, porque estes contariam com a

\footnotetext{
${ }^{361}$ MARINA, José Antonio. Crónicas de la ultramodernidad, cit., p. 106.

${ }^{362}$ DÍEZ RIPOLLÉS, José Luis. Exigencias sociales y politica criminal. Claves de Razón Práctica, n. 85, p. 48 e ss., set. 1998.

${ }^{363}$ Id. Ibid.

${ }^{364}$ ORTEGA Y GASSET, José. La rebelión de las masas. Madrid: P. Garagorri, 1988. p. 198.

${ }^{365}$ MESSNER, Steven; ROSENFELD, Richard. Crime and the American dream. Belmont: Wadsworth Pub. Co., 1997.

${ }^{366}$ MARINA, José Antonio. op. cit., p. 196.

${ }^{367}$ SILVA SÁNCHEZ, Jesús-María. A expansão do direito penal: aspectos da política criminal nas sociedades pós-industriais, cit., p. 77-78.
} 
atuação das seguradoras. Haveria, segundo o autor, uma "socialização do dano individualmente causado", com a máxima consequência de que os valores pagos a título de prêmio do seguro aumentariam, representando uma piora na eficácia preventiva. ${ }^{368}$ Acrescenta que a utilização constante dos contratos de seguro tende a padronizar as indenizações, o que afastaria ainda mais a possibilidade de garantir reparação mais próxima possível da integralidade do prejuízo, de forma que há uma clara defasagem de conteúdo na responsabilidade civil pelo abandono da ideia de culpa. ${ }^{369}$

Ainda há que se considerar uma particularidade quanto à Administração Pública, tão cheia de agentes corruptos que, muitas vezes tornam-se verdadeiros protagonistas de danos e geração de riscos, ao se unirem com detentores do poder socioeconômico. Isso torna o cenário catastrófico, porque a tão defendida ultima ratio do direito penal fica ainda mais abandonada, havendo verdadeira inversão, sendo o direito penal a prima ratio ao ser apresentado como mecanismo de socialização. ${ }^{370}$ Essa perspectiva aponta o direito penal como a suprema salvação dos problemas mundiais, algo que a política não deu conta de realizar. Algo como o imputar-lhe a função de resguardar o futuro das gerações sobre o planeta em que vivemos. ${ }^{371}$

Após considerar-se tudo o que foi dito logo acima, também é preciso ter em vista que há notas criminológicas com vieses de esquerda de modo a atribuir aos menos favorecidos a qualidade de titulares de bens jurídicos, isto é, a perspectiva de esquerda permitiu que surgissem e se desenvolvessem grupos de proteção à moral coletiva. ${ }^{372}$ Tratase dos gestores atípicos da moral, que embora se empenhem em defender o que entendem como justo, inclusive pleiteando a criminalização de diversas condutas, o que nem sempre se mostra adequado. ${ }^{373}$ Tais gestores formaram grupos bastante específicos, como os

\footnotetext{
${ }^{368}$ SILVA SÁNCHEZ, Jesús-María. A expansão do direito penal: aspectos da política criminal nas sociedades pós-industriais, cit., p. 78.

${ }^{369}$ Id. Ibid., p. 79. Vide, ainda SIMON, Jonathan. The emergence of a risk society: insurance, law, and the state. Socialist Review, n. 95, p. 61 e ss., 1987. Ademais, vide ARROYO ZAPATERO, Luis. Derecho y riesgo. Iniuria: revista de responsabilidade civil y seguro, n. 8, out./dez. 1995; e, ainda CODERCH, Pablo Salvador; CASTIÑEIRA PALOU, Maria Teresa. Prevenir y castigar. Madrid: Marcial Pons, 1997. p. 157; sobre a reparação como uma terceira via do direito penal, vide: MAIER, Julio B. J. ¿Es la reparación una tercera vía del derecho penal? Revista Brasileira de Ciências Criminais, São Paulo, v. 12, n. 50, p. 38, set./out. 2004.

${ }^{370}$ PALIERO, Carlo Enrico. L'autunno del patriarca. Rivista Italiana di Diritto e Procedura Penale, Milano, v. 37, t. 2, p. 1220-1250, 1994.

${ }^{371}$ Nesse sentido, SILVA SÁNCHEZ, Jesús-María. A expansão do direito penal: aspectos da política criminal nas sociedades pós-industriais, cit., p. 79-80.

${ }^{372}$ Sobre o tema: SILVA SÁNCHEZ, Jesús-Maria. Aproximación al derecho penal contemporáneo. Barcelona: Bosch, 1992. p. 23 e ss.

${ }^{373}$ DÍEZ RIPOLLÉS, José Luis. Exigencias sociales y politica criminal, cit., p. 51, fala do crime de assédio sexual criado na Espanha sob a batuta de partidos políticos para que pudessem atrair o feminismo. $\mathrm{O}$ mesmo pode-se dizer aqui no Brasil, com a criação do tipo penal equivalente.
} 
defensores do meio ambiente e dos consumidores, geralmente manifestando-se por meio de Organizações Não Governamentais - ONGs.

Curioso é que grupos que em outros tempos repudiavam a ingerência penal na vida dos cidadãos, agora anseiam maior presença do ramo criminal, a fim de que se combatam as classes mais fortes, poderosas, num exercício de fascínio pelo ramo mais opressor do direito. ${ }^{374}$

Um grande problema que se pode notar com base nos fatos acima relatados é a disseminação de um sentimento de repugnância relativo a direitos e garantias penais e processuais penais. Isto se verifica porque se deixa de lidar com os valores usualmente verificados no direito penal clássico. Em outras palavras, o que antes se entendia como um dos pilares da democracia passa a ser observado sob a óptica de que são empecilhos para que haja a resolução dos problemas.

Surge, então, o chamado "gerencialismo", que no âmbito da política criminal corresponde a um mecanismo de gestão eficiente de determinados problemas, sem que haja conexão com os valores clássicos do direito e processo penal. Isto ocorre porque há forte desconfiança pública quanto à eficácia penal, que passa a ser vista como algo dependente de aspectos burocráticos. ${ }^{375}$

Essa nova vertente do discurso criminológico é atuarial, isto é, atende a uma lógica que abandona o discurso correcionalista, tradicional no "welfare state". ${ }^{376}$ Assim, preferese gerenciar situações partindo da premissa de que vivemos em uma sociedade do risco, deixando de lado a moral e considerando-se os cálculos probabilísticos aplicados a certos grupos. As intervenções, destarte, buscam administrar grupos tidos como "perigosos", de modo a otimizar o gerenciamento de riscos. As práticas restariam apontadas para a antecipação das ações do delinquente. ${ }^{377}$

Isto acontece porque se deixa de ter percepção de que a delinquência é decorrente de certos problemas sociais. Considera-se, pois, que conceitos econômicos fundamentais são a base para explicar e atacar o crime, ${ }^{378}$ uma vez que o delito passa a ser considerado

\footnotetext{
${ }^{374}$ SILVA SÁNCHEZ, Jesús-María. A expansão do direito penal: aspectos da política criminal nas sociedades pós-industriais, cit., p. 80-81.

${ }^{375}$ Id. Ibid., p. $90-91$.

${ }^{376}$ AZEVEDO, Rodrigo Ghiringhelli de. Criminologia contemporânea. Porto Alegre: TRF - $4^{\text {a }}$ Região, 2008 (Currículo Permanente. Caderno de Direito Penal: módulo 4).

${ }^{377}$ Nesse sentido, FEELEY, Malcom; SIMON, Jonathan. The new penology: notes on the emerging strategy of corrections and its implications. Criminology, London, n. 20, 1992.

${ }^{378}$ RIVERA BEIRAS, Iñaki (Coord.). Política criminal y sistema penal. Barcelona: Anthropos, 2005. p. 234.
} 
uma escolha racional, quase uma atitude de ponderação do custo-benefício. ${ }^{379}$ É que o enfoque passa a ser outro, analisando-se economicamente o delito, numa concepção de "law and ecnonomics" em que a impunidade pode se tornar real impulso para a prática reiterada, ou seja, os proveitos obtidos com base em algumas condutas criminosas pode justificar o risco de eventual condenação penal. ${ }^{380}$

Nessa perspectiva, o chamado Estado neoliberal deixa de ter a pretensão de valer-se de uma função especial positiva da pena - a reeducação -, antes desejada pelo Estado social, para voltar à simplicidade do desejo de punição, não apenas uma punição, mas algo exemplar, algo que seja apto a criar um alarme social. ${ }^{381}$ Isso tudo realça a característica negocial da justiça penal, que passa a não se atentar como antes para os valores tradicionalmente retratados e defendidos do direito penal, mitigando-os. Exemplos disso, no Brasil, são as leis $9.080 / 95,{ }^{382} 9.613 / 98^{383}$ e $9.807 / 99,{ }^{384}$ que trazem em seu bojo as figuras de agentes colaboradores. ${ }^{385}$

${ }^{379}$ FUKUYAMA, Francis. A grande ruptura: a natureza humana e a reconstituição da ordem social. Tradução de Nivaldo Montingelli Jr. Rio de Janeiro: Rocco, 2000.

${ }^{380}$ MACHADO, Bruno Amaral. Duas "leituras" sobre a construção jurídica da impunidade. Revista de Informação Legislativa, Brasília, ano 43 n. 171, p. 281, jul./set. 2006.

${ }^{381}$ BERGALLI, Roberto. Relaciones entre control social y globalización: Fordismo y disciplina, Postfordismo y control punitivo. Revista Sociologías, Porto Alegre, ano 7, n. 13, p. 205, jan./jun. 2005.

${ }^{382}$ Essa lei altera outras, a 7.492/86 (crimes contra o sistema financeiro nacional) e a 8.137/90 (crimes contra a ordem tributária). Assim, no art. $1^{\circ}$ da 9.080 altera-se o art. 25 da Lei 7.492/86 para que conste o seguinte no $\S 2^{\mathrm{o}}$ "Nos crimes previstos nesta Lei, cometidos em quadrilha ou coautoria, o coautor ou partícipe que através de confissão espontânea revelar à autoridade policial ou judicial toda a trama delituosa terá a sua pena reduzida de um a dois terços." Por seu turno, o art. $2^{-}$altera o art. 16 da Lei 8.137/90 para que o parágrafo único conste que "Nos crimes previstos nesta Lei, cometidos em quadrilha ou coautoria, o coautor ou partícipe que através de confissão espontânea revelar à autoridade policial ou judicial toda a trama delituosa terá a sua pena reduzida de um a dois terços."

${ }^{383} \mathrm{O}$ art. $1^{\mathrm{o}}, \S 5^{\mathrm{o}}$ dispõe que: "A pena será reduzida de um a dois terços e começará a ser cumprida em regime aberto, podendo o juiz deixar de aplicá-la ou substituí-la por pena restritiva de direitos, se o autor, coautor ou partícipe colaborar espontaneamente com as autoridades, prestando esclarecimentos que conduzam à apuração das infrações penais e de sua autoria ou à localização dos bens, direitos ou valores objeto do crime." (grifo nosso)

${ }^{384}$ Especialmente verifica-se o aspecto negocial nos artigos 13 e 14 . Veja-se:

"Art. 13. Poderá o juiz, de ofício ou a requerimento das partes, conceder o perdão judicial e a consequente extinção da punibilidade ao acusado que, sendo primário, tenha colaborado efetiva e voluntariamente com a investigação e o processo criminal, desde que dessa colaboração tenha resultado:

I - a identificação dos demais coautores ou partícipes da ação criminosa;

II - a localização da vítima com a sua integridade física preservada;

III - a recuperação total ou parcial do produto do crime.

Parágrafo único. A concessão do perdão judicial levará em conta a personalidade do beneficiado e a natureza, circunstâncias, gravidade e repercussão social do fato criminoso.

Art. 14. O indiciado ou acusado que colaborar voluntariamente com a investigação policial e o processo criminal na identificação dos demais coautores ou partícipes do crime, na localização da vítima com vida e na recuperação total ou parcial do produto do crime, no caso de condenação, terá pena reduzida de um a dois terços.

${ }^{385}$ Nesse sentido, SILVA SÁNCHEZ, Jesús-María. A expansão do direito penal: aspectos da política criminal nas sociedades pós-industriais, cit., p. 90-91. 
Por outro lado, Silva Sánchez aponta o paradoxo criado por esta situação, em que a ânsia pela verificação de armas de rápida eficácia na luta contra o crime importa o desejo de flexibilização dos direitos e garantias e o relacionamento disso com a solução "privatizada" de conflitos que, embora tipificados, representam algo de menor lesividade. ${ }^{386}$ Quanto a isso, há quem discorra sobre uma resolução mais "suave" de ilícitos de menor relevância e suas relações com a eficiência do direito penal. ${ }^{387}$

De qualquer forma, essa nova concepção leva-nos a verificar, ainda, o fenômeno das privatizações, seja das prisões, seja da segurança, surgidas em virtude do descrédito nas ações públicas e sendo uma consequência natural da expansão. ${ }^{388}$ Ora, se há crescimento na participação do direito penal na sociedade e, ainda, havendo a falta de condições pelo Estado, seja na instância investigativa, seja na jurisdicional, é natural a crença de que a intervenção não tradicional tenha êxito. Obviamente, isso torna o direito penal um ramo mais carente de substrato que lhe dê legitimidade, porque verifica-se a vivência em sociedade, embora judicializada, desmoralizada, a ponto de se afirmar que a função preventivo-integradora do direito penal está atuando em seu limite. ${ }^{389}$ É nesse contexto que a privatização considerada nas mudanças que propiciam o abandono quanto à igualdade remaneja as direções contra o delito em nosso cotidiano, isto é, forma um contexto simbólico do direito penal, deslegitimando-o e, ademais, interferindo diretamente na eficácia preventiva que o citado ramo poderia ter.

\subsection{Algumas palavras sobre a sociedade de risco}

Nas considerações de Ulrich Beck, vivemos em uma sociedade de risco. O autor, um crítico da modernidade, aponta haver a modernização simples e a reflexiva, sendo tal dicotomia o fundamento da alteração de equilíbrio das condições de continuidade. Assim, a sociedade industrial clássica perde lugar para a sociedade mundial do risco.

\footnotetext{
${ }^{386}$ Nesse particular pode-se mencionar a Lei 9.099/95, que inaugurou o sistema brasileiro quanto aos chamados "delitos de menor potencial ofensivo", além do tratamento diferenciado a eles destinado, mitigando-se, por exemplo, a obrigatoriedade da propositura da ação penal.

${ }^{387}$ Para tanto, vide a obra de BONAFÉ-SCHMITT, Jean Pierre. La médiation, une justice douce. Paris: Syros, 1992.

${ }^{388}$ É o que defende SANZ DELGADO, Enrique, Las prisiones privadas: la participación privada en la ejecución penitenciaria. Madrid: Ed. Edifoser, 2000.

${ }^{389}$ SILVA SÁNCHEZ, Jesús-María. A expansão do direito penal: aspectos da política criminal nas sociedades pós-industriais, cit., p. 94.
} 
Ocorre que o progresso, a globalização e a percepção de riscos globais, advindos de forma silenciosa, sem planejamento, atingiram proporções não imaginadas. Pressupostos para o desenvolvimento econômico, a ciência e a tecnologia "viram-se desencantadas com o surgimento de riscos de grandes dimensões, que não haviam sido tematizados e muito menos previstos e que passaram a representar um potencial de perigo que não se pode medir, quantificar ou antever", 390

E isso se contrapõe a ideias mais antigas de que o acúmulo de conhecimento pelo enorme fluxo de informações aproximaria o mundo natural e social. De fato, não foi o que se passou, porque, apesar de imaginar-se que quanto mais desenvolvido o conhecimento humano, melhor seria a gestão do futuro, com mais elaboradas orientações.

Vale dizer que não seria equivocado afirmar que novas percepções sobre os riscos são a expressão do desenvolvimento da modernização das premissas. Assim, o desenvolvimento técnico e seu manejo permitiram que o homem se resguardasse de perigos naturais, como chuvas, ventanias, frio e calor excessivo. Entretanto, o mesmo avanço instituiu as ameaças tecnológicas, como as atividades nucleares e a vastíssima disseminação da tecnologia nas atividades mais comuns ao dia a dia humano.

A percepção de que há dois momentos distintos de verificação de riscos, feita por Beck, é bastante elucidativa. Para o autor, há relação muito próxima entre os efeitos da modernização e as estruturas sociais. ${ }^{391}$ Num primeiro momento o desenvolvimento técnico cria ameaças de forma sistemática, não sendo objeto de qualquer proteção social e sequer figurando entre discussões públicas ou políticas. Num segundo momento é que os riscos passam a ser foco de debates no seio da sociedade. Nesse ponto é que são questionadas as instituições de controle social, porque ou compactuaram com os desenfreados riscos, ou porque não foram capazes de minorá-los. Sem dúvida, a questão que vem à tona com base nessa constatação é a da necessidade de regulamentação de como implementar medidas de reforço à segurança, de limitação e individualização de responsabilidades e distribuição das consequências danosas.

Este é o contexto incorporado, cada vez mais, nas discussões penais, especialmente para fundamentar novas incriminações e institutos penais aplicados à realidade da

\footnotetext{
${ }^{390}$ MACHADO, Marta Rodriguez de Assis. Sociedade de risco e direito penal: uma avaliação de novas tendências político-criminais, cit., p. 20.

${ }^{391}$ Id. Ibid., p. 21.
} 
sociedade de risco. De fato, há inadequações da legislação e da dogmática penal verificadas nas modificações sociais referentes ao risco.

E os problemas surgem na medida em que, no que tange aos novos riscos, há posicionamento estatal no sentido de ampliação sancionatória, na busca desenfreada em evitar resultados indesejáveis. E isso não ocorre pela mera criação de tipos penais, mas também pela importância diferenciada que se oferece a bens jurídicos transindividuais, inclusive antecipando a tutela penal, fazendo-se previsão de tipos penais de perigo concreto, abstrato e até mesmo de precaução.

Não é à toa que surgem, então, discussões sobre a presença do Direito Penal nas regulações do meio ambiente, das atividades nucleares, de sistemas computacionais e, ainda, da biotecnologia. ${ }^{392} \mathrm{E}$, assim, os problemas acontecem justamente porque há lapsos entre as concepções mais antigas do Direito Penal, mais voltadas ao modelo liberal burguês, isto é, do modelo clássico ante as necessidades e anseios da modernidade. Em outros termos, a proteção e a regulamentação dos riscos vão ao encontro dos princípios e da estrutura do Direito Penal, constituídos para proteger bens jurídicos individuais.

Apesar do conflito acima, as novas perspectivas não são desconsideradas pela doutrina mais recente, havendo diversos penalistas que admitem expressamente a sociedade de risco vislumbrada por Beck, como são os casos de Baratta, ${ }^{393}$ Figueiredo Dias $^{394}$ e Silva Sánchez. ${ }^{395}$

\subsubsection{Da sociedade de risco como aproximação político-criminal ao direito penal}

É importante notar que as relações entre os penalistas e os sociólogos vêm sofrendo mudanças consideráveis desde a colocação em pauta de discussões da doutrina finalista. É que se tem buscado, cada vez mais, interligar o Direito Penal a valores de política criminal, integrando a dogmática da teoria do delito a políticas públicas coerentes com o que se deve entender por função do ramo criminal.

\footnotetext{
${ }^{392}$ Vide o nosso Crimes digitais, cit.

${ }^{393}$ BARATTA, Alessandro. Funciones instrumentales y simbólicas del derecho penal: uma discusión en la perspectiva de la criminologia crítica. Pena y Estado, Barcelona, n. 1, p. 37-55, 1991.

${ }^{394}$ DIAS, Jorge de Figueiredo. O direito penal entre a "sociedade industrial" e a "sociedade do risco". Revista Brasileira de Ciências Criminais, São Paulo, v. 33, ano 9, jan./mar. 2001.

${ }^{395}$ SILVA SÁNCHEZ, Jesús-María. La expansión del derecho penal: aspectos de la política criminal en las sociedades post industriales. Madrid: Civitas, 1999. p. 21.
} 
Fundamental é entender que a tentativa de vinculação de teorias do crime à política criminal torna o Direito Penal um tanto menos fechado nas suas interpretações e aplicações, inserindo-se (ou tentando-se inserir) dados da realidade e valores políticos no sistema penal. Neste ponto há claro toque entre as ciências penais e as sociais, uma vez que é a partir da política criminal que se pode verificar abertura para que novos riscos sejam absorvidos pelo direito, especialmente no ramo penal.

A insegurança presenciada ou sentida a partir de incertezas e novas situações percebidas e advindas do desenvolvimento acabam por determinar anseios sociais por segurança. Isto leva-nos a notar algumas explicações, justificando-se a intervenção penal. É o caso do argumento da possibilidade de destruição em massa e, antes mesmo disso, a própria desconfiança que se pode ter em relação à ciência.

De fato, o que se percebe empiricamente é que novos riscos são relacionados com decisões humanas, ${ }^{396}$ de forma que ao ocorrer um dano, imediatamente liga-se o resultado indesejado a um comportamento descuidado de alguém. ${ }^{397}$

O que se nota no tempo é que num Direito Penal mais antigo os desastres naturais eram considerados infrações penais, ocasião em que animais e coisas podiam ser responsabilizados. Por outro lado, um Direito Penal mais moderno exige que se oponham às noções de delito e ocorrências da natureza. ${ }^{398}$ Com isso, quer-se demonstrar que expectativas de regulação levam à inexorável expansão penal, exigindo-se deste ramo do Direito presença proporcional aos valores mais destacados e tidos como relevantes na sociedade atual. Em outras palavras, devem-se redirecionar as atenções do ordenamento jurídico aos novos desafios vivenciados pela Sociedade de Risco.

E isso pode se tornar um problema ainda mais complexo, tendo em vista que as expectativas por maior intervenção penal chocam-se, de alguma forma, com a demanda não atendida em termos de provimento de segurança. A partir daí à política criminal caberia solucionar a equação existente entre a complexidade fenomênica dos riscos e a regulamentação, pela lei penal, traduzida em tipos penais e outros institutos que se prestem a compor a desejada modernidade positivada.

\footnotetext{
${ }^{396}$ MACHADO, Marta Rodriguez de Assis. op. cit., p. 94.

${ }^{397}$ SEELMANN, Kurt. Societat de risc i dret. Iuris. Quaderns de Política Jurídica, Barcelona, n. 1, p. 271 e Ss., 1994.

${ }^{398}$ Id. Ibid.
} 
Para integrar essa situação, não é possível deixar de lado as características do crime em tempos atuais. Não à toa já se denominam os fenômenos delitivos atuais como “criminalidade moderna”, em contraposição à criminalidade de massa ou do dia a dia.

É lugar-comum apontar a criminalidade moderna sendo composta pelos delitos ambientais, econômicos, de tráfico de drogas e armas e, ainda, a criminalidade organizada. Muitos se esquecem dos crimes digitais, que devem igualmente ser inseridos nesse contexto e, que já deixaram há muito de ser algo restrito a poucas pessoas, ou por hackers. ${ }^{399}$

Essa delinquência moderna é apontada por Hassemer como detentora de características peculiares, como é o caso da inexistência de vítimas individuais (estas apenas presentes de forma mediata); ataques a bens jurídicos transindividuais; transnacionalidade; divisão de tarefas; não derramamento de sangue e profissionalidade. ${ }^{400}$

Com esse contexto em evidência, é absolutamente esperado que questionamentos surjam sobre a forma de atuação do Direito Penal nessa realidade. Então é que se aponta que o ramo criminal está estruturado de forma a proteger bens individuais, além de direcionar sua atuação à individualização de responsabilidades. ${ }^{401}$ Isso vai de encontro a características como origem difusa dos riscos, que igualmente atingem bens jurídicos difusos. É por esta razão, isto é, das sérias limitações do modelo penal tradicional no trato da macrocriminalidade, que Figueiredo Dias referiu-se a vias de adequação do paradigma penal atual aos problemas novos da sociedade do risco ${ }^{402}$ e que, Silva Sánchez anotou a absurda expansão penal, subvertendo o sistema atualmente adotado. ${ }^{403}$

Assim, sugere Hassemer que haja reestruturações penais e processuais penais, seja com a ampliação territorial do Direito Penal e previsão de delitos de perigo, seja com alterações quanto a mecanismos para a investigação. ${ }^{404}$ Também a voz de Figueiredo Dias ecoa quando se fala em adaptação do sistema vigente para atender a sociedade de risco, que propõe tendências político-criminais em voga da seguinte maneira: ampliação e

\footnotetext{
${ }^{399}$ Não à toa, percebendo esse fenômeno que escrevemos o trabalho de mestrado por esta Universidade e Faculdade, defendido perante banca examinadora em 2008: Delitos Informáticos e novos paradigmas do Direito Penal.

${ }^{400}$ HASSEMER, Winfried. Perspectivas de uma moderna política criminal. Revista Brasileira de Ciências Criminais, São Paulo, v. 2, n. 8, p. 41-51, out./dez. 1994.

${ }^{401}$ A doutrina aponta como problemas: "rígidos critérios de aferição da causalidade, do dolo, da negligência, do erro, da consciência do ilícito e dos demais elementos que antecedem a imputação", como se verifica em MACHADO, Marta Rodriguez de Assis. op. cit., p. 96.

${ }^{402}$ DIAS, Jorge de Figueiredo. Temas básicos da doutrina penal: sobre os fundamentos da doutrina penal, sobre a doutrina geral do crime. Coimbra: Coimbra Ed., 2001. p. 173.

${ }^{403}$ SILVA SÁNCHEZ, Jesús-María. La expansión del derecho penal: aspectos de la política criminal en las sociedades post industriales, cit., p. 45.

${ }^{404}$ HASSEMER, Winfried. Perspectivas de uma moderna política criminal, cit., p. 41-51.
} 
proteção de bens jurídicos transindividuais; alargamento e antecipação da tutela penal pela utilização de tipificações privilegiando o perigo abstrato; e, por fim, a releitura do conceito de culpabilidade para que sejam atingidas também as pessoas jurídicas. ${ }^{405}$

Não se discorda do penalista português, mas entende-se, no entanto, que também é preciso promover novos estudos sobre a composição da culpabilidade como elemento do delito, especialmente no que tange à sua formação com o elemento "consciência da ilicitude". Também é preciso atentar para o uso mais presente das chamadas normas penais em branco, da interpretação e da linguagem, que interferem de forma muito relevante na aplicação das normas jurídicas. Frise-se que essa problemática não passou despercebida pela doutrina, podendo-se citar José Eduardo de Oliveira Faria e Marta Machado. ${ }^{406}$

\subsubsection{Algumas palavras sobre bem jurídico no contexto da expansão e da sociedade de risco: a espiritualização}

Aquilo que se entende por bem jurídico não tem, na verdade, aceitação pacífica na doutrina. Sua noção começou a ganhar traços mais vigorosos, em termos dogmáticos, no início do século XVIII com o Iluminismo. Antes disso, é possível afirmar que o Direito Penal vivia momentos demasiadamente autoritários, de forma que as condutas delituosas eram definidas indeterminadamente. Além disso, não havia clara distinção entre os mandamentos de Deus do estatuto dos homens. ${ }^{407}$ Assim, as ideias que antecederam o esclarecimento iluminista eram no sentido de que o delito era mesmo um pecado. ${ }^{408}$

Foram pensadores como Benthan, Rousseau, Montesquieu e Voltaire que pretenderem dar novas direções ao Direito Penal, sendo uma amostra do novo direcionamento a obra de Cesare Bonesana, o Marquês de Beccaria, Dei Delitti e Delle Pene, de $1764 .^{409}$ A isso seguiu-se algum embate entre o racionalismo cartesiano e o

\footnotetext{
${ }^{405}$ DIAS, Jorge de Figueiredo. Temas básicos da doutrina penal: sobre os fundamentos da doutrina penal, sobre a doutrina geral do crime, cit., p. 173.

${ }^{406}$ FARIA, José Eduardo de Oliveira. O direito na economia globalizada. São Paulo: Malheiros Ed., 1999. pg. 132. MACHADO, Marta Rodriguez de Assis. op. cit.. pg. 100

${ }^{407}$ CEREZO MIR, José. Curso de derecho penal español: parte general. Madrid: Tecnos, 1985. p. 77.

${ }^{408}$ Nesse sentido, LISZT, Franz von. Tratado de derecho penal. 3. ed. Trad. Luís Jimenes de Asúa. Madrid: Reus, 1927. p. 19.

${ }^{409}$ Outros autores devem ser mencionados, como é o caso de Paschoal José de Mello Freire, em Portugal, e Karl Ferdinand Hommel, na Alemanha. Vide REALE JÚNIOR, Miguel. Teoria do delito, 1998, cit., p. 163; vide, ainda, CUNHA, Maria da Conceição Ferreira da. Constituição e crime: uma perspectiva da criminalização e da descriminalização. Porto: Universidade Católica Portuguesa, 1995. p. 31 e ss.
} 
empirismo inglês, levando, aos poucos, que o delito se livrasse das amarras éticoreligiosas, encontrando seu fundamento na violação de um contrato social. ${ }^{410}$

Em momento posterior vinculou-se ao delito a violação de direito subjetivo alheio, tendo como expoente Feuerbach, que desenvolveu estudos fundados na ideia de contrato social, em que os homens organizar-se-iam e confiariam ao Estado a conservação da ordem. ${ }^{411}$ Este só estaria legitimado a agir em casos de afronta aos direitos dos cidadãos, requerendo que houvesse verdadeira violação a direitos subjetivos, sob pena de não se falar em crime. Tal posicionamento recebeu críticas, porque essa mecânica punia situações que não causavam lesões a direitos subjetivos. Mudava-se, enfim, a concepção do fundamento da pena, que deixava de ser penitência para ser considerada retribuição a um atentado contra a sociedade.

Um pouco mais tarde, após a derrota de Napoleão, foi que se desenvolveu o pensamento de Birnbaum quanto ao que hoje conhecemos como bem jurídico. ${ }^{412}$ Sua obra referia-se a estudo sobre a tutela da honra, que modificou o direito penal de forma importante, haja vista ter-se deixado de lado o conceito vigente que vinculava crime a violação de direito subjetivo. Tal visão permitiu que as condutas delitivas devessem ser analisadas sob a óptica da lesão de bens, não apenas de contraposição a direitos.

Foi em 1834, que Birnbaum publicou a obra acima mencionada que o tornou referência de paternidade do chamado "bem jurídico". A falta de limites sobre a atuação estatal foi que levou a isso. De fato, a concepção desenvolvida por Feuerbach de que o delito resumia-se ao ataque de um direito subjetivo serviu de base para que fossem criadas ideias sobre como tornar mais contida a atuação penal.

Desta forma, pode-se dizer que a concepção mais antiga foi perdendo terreno para a ideia de que há juízos de valor sobre bens voltados à satisfação das necessidades humanas e que estão conectados às normas penais. Justamente por isso, merecem proteção penal, delineando as bases para a idealização de tipos penais.

\footnotetext{
${ }^{410}$ PRADO, Luiz Régis. Curso de direito penal brasileiro: parte geral. 3. ed. São Paulo: Ed. Revista dos Tribunais, 2002. p. 58-59.

${ }^{411}$ Id. Bem jurídico-penal e Constituição. 2. ed. São Paulo: Ed. Revista dos Tribunais, 1997. p. 29.

${ }^{412}$ Considerando-se a definição ampla de que se trata de um valor tutelado pela lei penal tendo em vista sua necessidade de permanência íntegra para a vida em sociedade. Obviamente não há consenso doutrinário sobre a exata definição. E, sem esquecer, ainda, que conforme a ideologia adotada, bem jurídico não será nada além de fidelidade ao ordenamento jurídico.
} 
Em suma, o que se verificou durante o Iluminismo foi alguma tentativa em limitar as arbitrariedades do Estado, o que se procurou fazer pela criação de um conceito material de crime.

Mas, o racionalismo presente na Restauração foi deixado de lado, abrindo-se espaço para outro, sem capacidade crítica. Binding, já em tempos de Escola Positiva, traz a dimensão formal e Rocco faz subjetivação da norma penal em favor do Estado. ${ }^{413}$ Nessa época, começou-se a defender a ideia de que as normas seriam anteriores ao Direito e proibiriam certas condutas de modo que, ao cometer um crime, agir-se-ia conforme a norma, mas contrário ao Direito.

O positivismo de Binding tinha como característica a perfeita coerência entre a norma e o bem jurídico, sendo que toda violação aos direitos subjetivos se produzia mediante agressão aos bens, inexistindo sem estes. ${ }^{414}$ Tudo o que fosse escolhido pelo legislador como condição para o bem-estar dos cidadãos seria considerado um bem jurídico. ${ }^{415}$ Eram, enfim, bens da comunidade, não havendo sentido na distinção de individuais e coletivos. Como criações do legislador, eram mera categoria formal.

Com os estudos de Liszt surgiu reação ao tratamento científico formal da norma, e o delito passou a ter conteúdo material, de forma que a norma não mais seria a criação do bem jurídico, mas direcionar-se-ia ao encontro dele. ${ }^{416}$

Uma nova concepção teleológico-metodológica de bem jurídico surgiu a partir do século XX, influenciada pela filosofia neokantista, ${ }^{417}$ determinando que fosse um valor abstrato e de cunho ético-social. A referência para o bem jurídico passou a se dar no mundo valorativo, não no social. ${ }^{418}$

As discussões com vistas a aprimorar-se a definição de bem jurídico tiveram muitas outras contribuições passando, inclusive, por teorias negativistas ${ }^{419}$ antes de alcançar-se as

\footnotetext{
${ }^{413}$ PRADO, Luiz Régis. Bem jurídico-penal e Constituição, cit., p. 32.

${ }^{414}$ KAUFMANN, Armin. Teoría de las normas. Trad. de Enrique Bacigalupo e Ernesto Garzón Valdés: Buenos Aires: Depalma, 1977. p. 14.

${ }^{415}$ ANGIONI, Francesco. Contenuto e funzioni del concetto di benne giuridico. Chiarella: Sassari, 1980. p. 76.

${ }^{416}$ PRADO, Luiz Régis. Bem jurídico-penal e Constituição, cit., p. 35.

${ }^{417}$ Doutrina que abarca duas escolas: a social de Marburgo e a Subocidental alemã ou de Baden. Para mais detalhes, vide CAMARGO, Antonio Luis Chaves. Imputação objetiva e direito penal brasileiro,cit., p. 2128; SILVEIRA, Renato de Mello Jorge. Direito penal supra-individual: interesses difusos. São Paulo: Ed. Revista dos Tribunais, 2003. p. 36-48.

${ }^{418}$ PRADO, Luiz Régis. Bem jurídico-penal e Constituição, cit., p. 37.

${ }^{419}$ Verificada especialmente pela Escola de Kiel, totalitária, onde era incompatível a ideia de bem jurídico com as diretrizes ditatoriais. Expoentes dessa Escola foram Schaffstein e Dahm, que desenvolveram ideias relativas a um Direito Penal do autor (portanto, não amparados na culpabilidade). Vide: CAMARGO, Antonio Luis Chaves. op. cit., p. 28-29.
} 
concepções mais modernas. Welzel entendia o bem jurídico como sendo aquele vital ao indivíduo ou à comunidade, ressaltando que se trata do estado social desejável que o Direito queira proteger de lesões. ${ }^{420}$ Já Jescheck vê os bens jurídicos como aqueles indispensáveis para a convivência humana em comunidade e que devem ser protegidos pelo poder de coação do Estado, pela imposição de penas. ${ }^{421}$ Roxin ressalta haver, ainda, os bens da comunidade que também demandam proteção ${ }^{422}$ e, mais recentemente, estudiosos da "escola de Frankfurt" pregam um Direito Penal Mínimo, que reconhece a proteção de bens jurídicos individuais e, apenas legitimaria a proteção a bens jurídicos supraindividuais na medida em que produzissem efeitos lesivos sobre as pessoas. ${ }^{423}$

E quanto aos bens jurídicos, é possível afirmar, basicamente, que existem duas vertentes de vanguarda: as teorias sociológicas e as constitucionais. ${ }^{424}$ A primeira delas tem como expoentes Knut Amelung, Winfried Hassemer e Jürgen Habermas, e a outra tem como referências Claus Roxin e Hans-Joachim Rudolphi.

Amelung, em visão considerada sociológica, fundamenta em Parsons e Luhmann seus estudos, comentando a disfunção sistêmica inerente ao bem jurídico, concluindo que, tudo aquilo que for condição para vida saudável da comunidade será considerado bem jurídico. A questão mais difícil de ser resolvida aqui é justamente estabelecer quais os parâmetros para declarar o que é ou não essencial. Desta forma, o que se verifica é o regresso ao conceito de Binding em que o parâmetro será a vontade do legislador no seu peculiar entender de que seja essencialidade. ${ }^{425}$ Por seu turno, Hassemer defende a ideia da necessidade de dano social para que se autorize atuação do Estado no ramo criminal, de forma que bens jurídicos sejam considerados conforme uma política criminal geral. ${ }^{426}$ Já outro pensador, Habermas, defende a "teoria do consenso (social)", que se funda na busca de uma identidade racional de forma que a criminalização seria apenas possível quando houvesse consenso intersubjetivo. ${ }^{427}$

\footnotetext{
${ }^{420}$ WELZEL, Hans. Derecho penal alemán. Traducción de Juan Bustos Ramírez y Sergio Yáñez Pérez. Santiago de Chile: Jurídica de Chile, 1997. p. 5 e ss.

${ }^{421}$ JESCHECK, Hans-Heinrich. Tratado de derecho penal: parte general. Traducción de José Luis Manzanares Samiego. 4. ed. Granada: Comares, 1993. p. 6.

${ }^{422}$ ROXIN, Claus. Derecho penal: parte general. 2. ed., cit., t. 1.

${ }^{423}$ CORCOY BIDASOLO, Mirentxu. Delitos de peligro y protección de bienes jurídico-penales supraindividuales. Valencia: Tirant lo Blanch, 1999. p. 20.

${ }^{424}$ Nesse sentido: SILVEIRA, Renato de Mello Jorge. op. cit., p. 48.

${ }^{425}$ Id. Ibid., p. 49.

${ }^{426}$ Id. Ibid.

${ }^{427}$ Id. Ibid.
} 
Ciente das teorias sociológicas, Roxin as criticou por entender que não definem bens jurídicos, igualmente não explicando os motivos da criminalização de certas condutas. ${ }^{428}$ Assim, o autor parte da noção de que a Constituição é o ponto fulcral para que se restrinjam os bens jurídicos. Para ele, a definição parte de visão político-criminal derivada da lei maior, fundando-se na liberdade das pessoas e na capacidade punitiva do Estado. Destarte, serão merecedores de tutela penal todos os mecanismos úteis para o livre desenvolvimento do indivíduo.

Rudolphi também defende que os valores essenciais tenham referência constitucional, vinculando o legislador infraconstitucional em verdadeira defesa de justiça material, tendo a tutela penal função eminentemente social. ${ }^{429}$

Havendo essas várias posições sobre o que sejam e como devem ser definidos os parâmetros para fixação de valores tutelados pelo Direito Penal, verifica-se como majoritária a ideia de que a limitação está intimamente relacionada com o poder punitivo do Estado. ${ }^{430}$ E isso é fundamental na verificação se estamos em um Estado Democrático ou em um Estado autoritário. Neste, o bem jurídico terá acepção totalmente diferente daquele.

Em suma, sob a perspectiva individual, são aqueles valores que devem receber maior proteção estatal ao passo que os difusos são vislumbrados a partir de uma massa não definida, de modo que passa a ser crucial a efetiva lesão em seus membros. ${ }^{431}$

A título de encaminhamento para uma conclusão quanto ao conceito de bem jurídico, apesar das diversas discussões sobre seu conceito, há um certo consenso sobre seu núcleo essencial, isto é, todo interesse humano que requeira proteção penal. ${ }^{432}$

\footnotetext{
${ }^{428}$ ROXIN, Claus. Política criminal e sistema jurídico-penal, cit.

${ }^{429}$ SILVEIRA, Renato de Mello Jorge. op. cit., p. 51.

${ }^{430}$ Jakobs, no entanto, defende posição diversa entendendo ser função do Direito Penal única e exclusivamente a revalidação da norma penal. Vide: JAKOBS, Günther. Derecho penal: parte general: fundamentos y teoría de la imputación, cit., p. 44 e ss.; vide, ainda, para uma boa compreensão da teoría de Jakobs: LESCH, Heiko. Intervención delictiva e imputación objetiva. Trad. Javier Sánches e Vera GomezTrélles. Bogotá: Universidad Externado de Colômbia, 1995; com entendimento bastante peculiar, resolvendo muitas questões penais no ámbito do comportamento típico, em vez da realização do risco, como grande parte da doutrina, FRISCH, Wolfgang. Tipo penal e imputación objetiva. Trad. Manuel Cancio, Meliá Beatriz de la Gándara Vallejo, Manuel Jaén Vallejo e Yesid Reyes Alvarado. Madrid: Constitución y Leys, 1995.

${ }^{431}$ SILVEIRA, Renato de Mello Jorge. op. cit., p. 53.

${ }^{432}$ HASSEMER, Winfried. Lineamentos de una teoría personal del bien jurídico. Doctrina Penal, Buenos Aires, n. 12, p. 275-285, abr./set. 1989; SILVA SÁNCHEZ, Jesús-Maria. Aproximación al derecho penal contemporáneo, cit., 1992, p. 270.
} 
Com esta breve exposição quer-se demonstrar que é de suma importância identificar o que sejam os bens jurídicos e, consequentemente, a função do direito penal para que se estruture um sistema punitivo coerente, uma vez que com a definição em mente poder-se-á sustentar pela incriminação ou de certas condutas e, ainda, ponderar-se sobre a consciência da ilicitude nestes casos.

\subsubsection{A proteção a interesses transindividuais}

Os caminhos trilhados quanto ao desenvolvimento do conceito de bem jurídico acima explicitados tornam perceptíveis outras características do Direito Penal na Sociedade de Risco. Uma delas diz respeito exatamente quanto à tutela penal de bens jurídicos que transcendem ao âmbito individual, vinculado a vítimas indefinidas. Em outras palavras, há incidência do ramo penal sobre preocupações que resvalam em interesses supraindividuais.

Há quem sustente que esse panorama - a possibilidade de apontar diferenças entre o tipo penal do seu objeto de proteção pela existência da noção de bem jurídico - permitiu compreender valores aos quais o ordenamento jurídico confere dignidade e consequente tutela. $^{433}$ Inclusive afirma-se que foi emprestando referência central às pessoas que se evitou nova vinculação a valores puramente morais, como ocorreu à época da Escola de Kiel, que voltou a força do Estado para a proteção da "sã consciência do povo alemão" 434

A ideia de se fundamentar que os valores devem ser vinculados de alguma forma com as pessoas, evitando-se apropriação da defesa de valores morais pelo Estado, é de Welzel que, ansioso por desenvolver teoria que deslegitimasse os abusos da época da guerra, buscou centralizar o sentido de "valor" a um indivíduo. ${ }^{435}$ Nessa concepção, as violações residem na relação dos bens tutelados com o indivíduo, e a proteção penal só é justificada tendo-se em conta a época, o momento e a conjuntura de muitos fatores sociais. Isso com vistas a elevar à condição de protegidos apenas os bens que tenham algum conteúdo destinado ao desenvolvimento do homem em sociedade. Tudo o que não influenciasse essa realização não seria digno de proteção. Eis aqui uma clara amostra de que o Direito Penal é fundamentado em ideologias, sendo elas as diretrizes fundamentais

\footnotetext{
${ }^{433}$ MACHADO, Marta Rodriguez de Assis. op. cit., p. 104.

${ }^{434}$ Id. Ibid.

${ }^{435}$ Para ele é a relação do indivíduo com o objeto que determina o valor, formando-se, assim, estrutura material relacional.
} 
para apontamento do que merece a proteção penal. Mesmo quando se aponta que é necessário relacionar o ramo criminal com a realidade social, fundando-o ao Estado Social de Direito, ${ }^{436}$ está se impondo uma ideologia a serviço desta ramificação.

Ocorre que essa visão sobre valores protegidos vem mudando. Questionam-se os limites de atuação do Estado pela aplicação do Direito Penal pela incorporação, aos valores tradicionalmente protegidos, de outros, transindividuais. Em outras palavras, o que fica em exposição nas discussões é a realidade político-criminal de se privilegiar a proteção a bens de conteúdo amplo, abstrato, deixando-se em segundo plano o enfrentamento de lesões mais concretas inerentes aos bens jurídicos tradicionais.

Há vozes no sentido disso representar movimento irreversível e até mesmo necessário para manter o desenvolvimento social em que nos encontramos uma vez que é reconhecida a necessidade de se proteger bens coletivos. ${ }^{437}$ Esse movimento dito irreversível significa, na prática, alterar o conceito de bem jurídico, ampliando-o e distanciando-o da vinculação a núcleos individuais, direcionando a proteção a bens universais, o que confronta com o modelo clássico do ramo penal. Trata-se da “desmaterialização" do bem jurídico.

Este panorama da "desmaterialização" dos bens jurídicos diante das novas tendências promovidas pela sociedade do risco mostra-nos haver punições criminais para condutas que frequentemente não passam de mera transgressão a uma norma organizativa, sem resultado concreto. Deixa-se de punir apenas as lesões, antecipando-se aos resultados danosos. Vê-se, claramente, o distanciamento do típico entendimento de bem jurídico, de visão antropocêntrica e orientado a bens particulares, para a tendência de "desmaterialização", "espiritualização" ou "dinamização" do bem jurídico, o que, obviamente, influi na teoria do delito.

Também se chegou a mencionar sobre a "dinamização" de bens protegidos que não representa apenas e tão somente o deslocamento da relação entre Estado e sociedade quanto à proteção do que a lei penal deve proteger, mas também a assunção, pelo mesmo

\footnotetext{
${ }^{436}$ MOCCIA, Sérgio. De la tutela de bienes a la tutela de funciones: entre ilusiones postmodernas y reflujos iliberales. In: SILVA SÁNCHEZ, Jesús-María (Org). Política criminal y nuevo derecho penal. Barcelona: Bosch, 1997. p. 114.

${ }^{437}$ Neste sentido, entre outros, vide MATA Y MARTÍN, Ricardo. Bienes jurídicos intermédios y delitos de peligro. Granada: Comares, 1997; KUHLEN, Lothar. La autocompreensión de la ciencia jurídico-penal frente a los desafios de su tiempo. Trad. Pastora García Álvarez. La ciencia del derecho penal ante el nuevo milênio. Valencia: Tirant lo Blanch, 2004.
} 
Estado, da produção dos valores a serem protegidos e o controle dos riscos. ${ }^{438}$ Estas colocações são coerentes com o que se verifica na prática: valores impostos pelo Estado e que se referem à sua infraestrutura e funções e que levam a ele mesmo a situação de garantidor quanto aos riscos.

Filippo Sgubbi, estudando esta situação, identificou dois processos de ampliação da proteção penal de bens: a criação artificial e a nacionalização de bens. ${ }^{439} \mathrm{O}$ primeiro relaciona-se com o monopólio estatal da proteção de bens em função da criação artificial deles. Sua criação se dá por coincidirem com os fins institucionais, não por terem sustento cultural ou social. Como exemplos, podem ser apontadas as normas penais que regulam a atividade econômica e que incriminam a não observação da regulamentação em favor de algo que se propõe como de utilidade pública.

Com relação a uma formação de monopólio do bem jurídico pelo Estado, isso se dá pela nacionalização ou expropriação de bens. Aqui eles são protegidos por não pertencerem a sujeitos individuais, mas porque o Estado deles se apropria, transformandoos em objeto de soberania geralmente visando à proteção da qualidade de vida e direitos sociais. Como exemplos podem ser apontados o meio ambiente e a saúde pública.

Nesse panorama, o Direito Penal se mostra um instrumento executivo para as políticas concernentes a esses bens, embora no modelo clássico não se encaixem nas especificações de bens tutelados. Destarte, observa-se o surgimento de uma política com finalidade de auxiliar a organização das atividades do Estado, de acordo com as valorações estatais de conveniência e oportunidade. Dito de outra forma, o direito penal passa a ser utilizado para controlar condutas danosas a interesses funcionais para o bem-estar da sociedade.

Neste ponto é possível identificar que a organização das atividades estatais com o uso do Direito Penal tutelando bens difusos deixa clara a preocupação com a proibição de condutas que possam, de alguma forma, atravancar a consecução dos objetivos perseguidos pelo Estado. É a identificação de um bem relacionado com a finalidade social que fundamenta tal acontecimento.

\footnotetext{
${ }^{438}$ BARATTA, Alessandro. Funciones instrumentales y simbólicas del derecho penal: uma discusión en la perspectiva de la criminologia crítica, cit., p. 37-55.

${ }^{439}$ SGUBBI, Filippo. El delito como riesgo social: investigación sobre las opciones en la asignación de la ilegalidad penal. Buenos Aires: Editorial Ábaco, 1998. p. 63 e ss.
} 
Não foi à toa que Buergo apontou que a proteção conferida pelo ramo penal a bens coletivos se contrapõe à noção clássica de delito trazendo ínsita a substituição da proteção de bens concretos pela de funções. ${ }^{440}$

Como já bem apontou a doutrina, a ideia de bem jurídico espiritualizado explica muitas das novas feições do objeto de proteção, embora isso não permita que se percebam exatamente situações de potencial dano ao bem jurídico, dificultando a aplicação da lei penal. De qualquer forma, tal concepção encontra-se difundida e aceita como fundamento à tipicidade de crimes de perigo. ${ }^{441}$

\subsection{Da expansão penal na realidade brasileira}

Visto que a expansão do Direito Penal apresenta algumas características peculiares, neste tópico busca-se mostrar, no Brasil, a presença do referido fenômeno, seja pela apresentação da proteção penal sobre novos interesses e existência de novos riscos, pela demonstração de que isso reflete alguma sensação social de insegurança, seja pela configuração de sociedade de sujeitos passivos, pelo descrédito em outras instâncias de proteção e até mesmo pelos gestores atípicos da moral.

Particularmente, quanto à sensação social de insegurança, a título de exemplo, menciona-se pesquisa do Instituto Brasileiro de Geografia e Estatística (IBGE), divulgada em 2009 sobre "Características da vitimização e do acesso à justiça no Brasil" que mostrou que $47,2 \%$ das pessoas não se sentem seguras na cidade em que moram. ${ }^{442}$

Curiosa é a forma com que são apresentados os dados: "Em 2009, 78,6\% das pessoas de 10 anos ou mais de idade se sentiam seguras no domicílio em que residiam $67,1 \%$ no bairro e 52,8\% na cidade. Os homens declararam sentirem-se mais seguros do

\footnotetext{
${ }^{440}$ MENDOZA BUERGO, Blanca. El derecho penal em la sociedad del riesgo, cit., p. 73.

${ }^{441}$ SILVEIRA, Renato de Mello Jorge. Direito penal econômico como direito penal de risco. São Paulo: Ed. Revista dos Tribunais, 2006. p. 154.

${ }^{442}$ IBGE. $47,2 \%$ das pessoas não se sentem seguras na cidade em que moram. Disponível em: <http://www.ibge.gov.br/home/presidencia/noticias/noticia_visualiza.php?id_noticia=1786\&id_pagina=1>. Acesso em: 09 out. 2011. A pesquisa avaliou a sensação de segurança com relação ao domicílio, ao bairro e à cidade onde residiam num total de 162,8 milhões de pessoas de 10 anos ou mais de idade. Enquanto $78,6 \%$ dessa população (127,9 milhões de pessoas) se sentiam seguras no domicílio, no bairro o percentual foi de $67,1 \%$ (109,2 milhões) e, na cidade, caiu para 52,8\% (85,9 milhões). A Região Norte teve os menores percentuais de pessoas que declararam se sentirem seguras (domicílio 71,6\%, bairro 59,8\% e cidade 48,2\%), enquanto a Região Sul apresentou as maiores proporções (81,9\% no domicílio,72,6\% no bairro e $60,5 \%$ na cidade).
} 
que as mulheres em todos os locais. A sensação de segurança no domicílio teve proporções maiores na população com maior rendimento médio mensal domiciliar per capita (82,8\% para cinco ou mais salários mínimos contra $77,8 \%$ para menos de $1 / 4$ de salário mínimo). Esta relação se inverteu para o sentimento de segurança no bairro $(62,8 \%$ contra $71,3 \%)$ e na cidade $(41,4 \%$ contra $60,9 \%)$. A Região Norte teve os menores percentuais de pessoas que declararam se sentirem seguras (domicílio 71,6\%, bairro 59,8\% e cidade 48,2\%)." Apesar disso, o título da matéria divulgada no site foi "47,2\% das pessoas não se sentem seguras na cidade em que moram", ainda que a pesquisa mostre que “A sensação de segurança no domicílio teve proporções maiores na população com maior rendimento médio mensal domiciliar per capita (82,8\% para cinco ou mais salários mínimos contra 77,8\% para menos de 1/4 de salário mínimo).”

Outro exemplo pode ser dado com base no advento da Lei 12.403/11, sobre a reforma processual penal, especialmente quanto às prisões cautelares, o que fez com que logo houvessem manifestações alardeando que "200.000 prisões em flagrante devem ser revistas prontamente, a partir do dia 4 de julho. Os presos não comprovadamente perigosos e/ou primários, poderão ter liberdade, com ou sem medidas cautelares alternativas"443 e, ainda, que "80 mil presos serão soltos no Brasil a partir do dia 5."444

O cenário de promoção de insegurança torna-se mais claro quando até mesmo operadores do direito, como até mesmo promotores de justiça se valem mais da emoção do que da técnica para exacerbarem o medo no seio social. ${ }^{445}$

\footnotetext{
${ }^{443}$ GOMES, Luiz Flávio. O efeito mais bombastico da nova lei de prisões-e-o-seguinte. Disponível em: $<$ http://www.ipclfg.com.br/artigos-do-prof-lfg/o-efeito-mais-bombastico-da-nova-lei-de-prisoes-e-oseguinte/>. Acesso em: 09 out. 2011.

${ }^{444} 80$ MIL presos serão soltos no Brasil a partir do dia 5. Brasil 247. Disponível em: $<$ http://brasil247.com.br/pt/247/brasil/6044/80-mil-presos-ser\%C3\%A3o-soltos-no-Brasil-a-partir-do-dia5.htm>. Acesso em: 09 out. 2011. A matéria traz trechos que deixam claro o discurso do medo. Veja-se: "Essa lei é um grave equívoco", afirma o desembargador Eduardo Pereira Santos. "O Poder Executivo não investe no sistema penitenciário, mas não é por isso que a sociedade tem de arcar com a convivência com criminosos."

O promotor paulista Marcelo Barone manifesta posição semelhante. "Com essa lei, a presunção relativa de inocência para um acusado se torna presunção absoluta, o que não existe em nenhum lugar do mundo", afirma ele. "As cadeias, aqui, irão se tornar apenas hotéis de trânsito" (leia aqui mais repercussão).

A legislação foi uma maneira que os parlamentares, com apoio do governo, encontraram para diminuir a superlotação do sistema carcerário nacional. Com ela, nada menos que $20 \%$ dos atuais presos poderão estar de volta às ruas. O déficit de vagas nas penitenciárias é estimado em 180 mil.

${ }^{445}$ DESABAFO de um promotor sobre a Lei 12.403/2011. Disponível em: $<$ http://www.direitolegal.org/artigos/desabafo-de-um-promotor-sobre-a-lei-12-4032011/>. Acesso em: 09 out. 2011 e reproduzido em mais de uma dezena de sites e até mesmo em vídeo no YouTube. Veja-se a íntegra: 
Veja que por estas breves amostras, pode-se dar razão ao que Silva Sánchez já havia dito sobre os meios de comunicação e instituições públicas "transmitirem imagens oblíquas da realidade, que contribuem com a difusão da sensação de insegurança". 446

Já no que tange aos novos riscos, tem-se que a sociedade de risco atual é responsável pelo "incremento desmedido que ganharam, nos últimos anos, os crimes de perigo abstrato, os quais representam a mais nítida forma do que hoje se está a chamar de

PORTUGUÊS (os livro [sic]) E AGORA LEI PARA FACILITAR A VIDA DE BANDIDOS. LEIAM AS DECLARAÇÕES ABAIXO:

Veja o Desabafo de um Promotor

"Um país sem limites se autodestrói"

Lei 12.403 e o desabafo de um Promotor.

Nada é tão ruim que não possa piorar.

Caros colegas, após 15 anos de atuação na área criminal estou pensando seriamente em abandonar a área com a nova LEI 12.403/2011 aprovada pelo CONGRESSO NACIONAL e sancionada em 05/05/2011 pela Presidente DILMA ROUSSEFF e pelo Ministro da Justiça JOSÉ EDUARDO CARDOZO.

Quem não é da área, fique sabendo que em 60 dias (05/07/2011) a nova lei entra em vigor e a PRISÃO EM FLAGRANTE E PRISÃO PREVENTIVA SOMENTE OCORRERÃO EM CASOS RARÍSSIMOS, aumentando a impunidade no país. Em tese somente vai ficar preso quem cometer HOMICÍDIO QUALIFICADO, ESTUPRO, TRÁFICO DE ENTORPECENTES, LATROCÍNIO etc. A nova lei trouxe a exigência de manter a prisão em flagrante ou decretar a prisão preventiva somente em situações excepcionais, prevendo a CONVERSÃO DA PRISÃO EM FLAGRANTE ou SUBSTITUIÇÃO DA PRISÃO PREVENTIVA em 9 tipos de MEDIDAS CAUTELARES praticamente inócuas e sem meios de fiscalização (comparecimento periódico no fórum para justificar suas atividades, proibição de frequentar determinados lugares, afastamento de pessoas, proibição de se ausentar da comarca onde reside, recolhimento domiciliar durante a noite, suspensão de exercício de função pública, arbitramento de fiança, internamento em clínica de tratamento e monitoramento eletrônico).

Para quem não é da área, isso significa que crimes como homicídio simples, roubo à mão armada, lesão corporal gravíssima, uso de armas restritas (fuzil, pistola $9 \mathrm{~mm}$ etc.), desvio de dinheiro público, corrupção passiva, peculato, extorsão etc., dificilmente admitirão a PRISÃO PREVENTIVA ou a manutenção da PRISÃO EM FLAGRANTE, pois em todos esses casos será cabível a conversão da prisão em uma das 9 MEDIDAS CAUTELARES acima previstas. Portanto, nos próximos meses não se assuste se você encontrar na rua o assaltante que entrou armado em sua casa, o ladrão que roubou seu carro, o criminoso que desviou milhões de reais dos cofres públicos, o bandido que estava circulando com uma pistola $9 \mathrm{~mm}$ em via pública etc. Além disso, a nova lei estendeu a fiança para crimes punidos com até 4 anos de prisão, coisa que não era permitida desde 1940 pelo Código de Processo Penal! Agora, nos crimes de porte de arma de fogo, disparo de arma de fogo, furto simples, receptação, apropriação indébita, homicídio culposo no trânsito, cárcere privado, corrupção de menores, formação de quadrilha, contrabando, armazenamento e transmissão de foto pornográfica de criança, assédio de criança para fins libidinosos, destruição de bem público, comercialização de produto agrotóxico sem origem, emissão de duplicata falsa, e vários outros crimes punidos com até 4 anos de prisão, ninguém permanece preso (só se for reincidente). Em todos esses casos o Delegado irá arbitrar fiança diretamente, sem análise do Promotor e do Juiz. Resultado: o criminoso não passará uma noite na cadeia e sairá livre pagando uma fiança que se inicia em 1 salário mínimo! Esse pode ser o preço do seu carro furtado e vendido no Paraguai, do seu computador receptado, da morte de um parente no trânsito, do assédio de sua filha, daquele que está transportando 1 tonelada de produtos contrabandeados, do cidadão que estava na praça onde seu filho frequenta portando uma arma de fogo, do cidadão que usa um menor de 10 anos para cometer crimes etc.

Em resumo, salvo em crimes gravíssimos, com a entrada em vigor das novas regras, quase ninguém ficará preso após cometer vários tipos de crimes que afetam diariamente a sociedade. Para que não fique qualquer dúvida sobre o que estou dizendo, vejam a lei.

GIOVANI FERRI,

Promotor de Justiça de Toledo-PR

${ }^{446}$ SILVA SÁNCHEZ, Jesús-María. A expansão do direito penal: aspectos da política criminal nas sociedades pós-industriais, cit., p. 49. 
tutela penal antecipada". ${ }^{447}$ Renato de Mello Jorge Silveira esclarece, ainda, que "contrapondo a tendência presente nos anos 50 e 60, quando fora notado movimento de descriminalização de condutas, os anos 70, 80 e 90 são marcados por uma clara expansão do Direito Penal, mais especificamente a um chamado Direito Penal de risco (Risikostrafrecht)". ${ }^{448}$

Esse fenômeno também se mostrou presente no Brasil, e especialmente quanto à proteção dos interesses difusos pode-se notar, baseado em nossa Constituição, dispositivos que mencionam o meio ambiente, a atividade econômica e, ainda, os direitos do consumidor. É o que se nota pela leitura dos artigos $225, \S 3^{\mathrm{o}}{ }^{449} 170^{450}$ e $5^{\mathrm{o}}$, XXXII, ${ }^{451}$ respectivamente.

No entanto, o fato de haver as previsões constitucionais supracitadas não significa em absoluto que se deva promover indistintamente a tutela penal dos bens jurídicos mencionados, violando-se a tão comentada como essencial ultima ratio do Direito Penal. Tais bens deveriam receber a tutela estatal sob o crivo penal apenas e tão somente por ocasião de que as demais formas de controle não se mostrem eficazes. ${ }^{452}$

Nesse particular insta mencionar que nosso Código Penal - a despeito da reforma da parte geral promovida nos meados da década de 80 - data de 1940, pelo que, ainda que se fosse possível encontrar previsões penais quanto aos bens jurídicos difusos, a maior parte das tipificações encontra espaço na legislação esparsa. Isto porque a proteção aos bens transindividuais não se mostrava previsível por ocasião da elaboração do nosso Código há mais de setenta anos de forma que, por esta razão, o direito penal quanto a bens

\footnotetext{
${ }^{447}$ SILVEIRA, Renato de Mello Jorge. Direito penal supra-individual: interesses difusos, cit., p. 121. O autor menciona, quanto a isso, GRASSO, Giovanni. L'antecipazione dela tutela penale: i reati di pericolo e i reati di attentato. Revista Italiana di Diritto e Procedura Penale, Milano, p. 689 e ss., 1997.

${ }^{448}$ Id. Ibid. Menciona o autor que o "Direito Penal de Risco" apareceu inicialmente em obra de Jürgen Wolter que tratou do "acréscimo pessoal e objetivo do comportamento à Lesão e Perigo num Sistema Criminal Funcional", complementando, ainda, que foi a partir da obra de Ulrich Beck, de 1986, que a importância do risco foi ampliada extrapolando os limites dos tipos penais para englobar a própria sociedade. Prossegue lecionando que, foi a partir dos anos 90 que os estudos se aprofundaram, merecendo maior preocupação pela Escola de Frankfurt.

${ }^{449 ،(. . .)}$ as condutas e atividades consideradas lesivas ao meio ambiente sujeitarão os infratores, pessoas físicas ou jurídicas, a sanções penais e administrativas, independentemente da obrigação de reparar os danos causados."

450، (...) a ordem econômica, fundada na valorização do trabalho humano e na livre iniciativa, tem por fim assegurar, a todos, existência digna conforme os ditames da justiça social."

451 “...) o Estado promoverá, na forma da lei, a defesa do consumidor."

${ }^{452}$ CUNHA, Maria da Conceição Ferreira da. op. cit., p. 360.
} 
difusos encontra-se pontualmente previsto no Código Penal, mas também em inovações legais posteriores. ${ }^{453}$

Diante desse cenário, passa-se a exemplificar formas de previsão criminal quanto a bens difusos na legislação brasileira, sempre com vistas a demonstrar as notas da expansão penal em nossa realidade.

São várias as passagens do Código Penal em que se encontram tipos penais preocupados com situações de perigo concreto e abstrato, muitas vezes deixando-se de considerar a potencialidade do risco, preocupando-se mais com sua sumária proibição, desconsiderando a real afetação ao bem que se quer proteger. É o que se pode verificar, por exemplo, no título "Dos Crimes contra a Incolumidade Pública", onde se encontram os tipos penais de incêndio (art. 250, CP), de epidemia (art. 267, CP), de envenenamento de água potável ou substância alimentícia ou medicinal (art. 270, CP), falsificação e corrupção de produtos alimentícios (art. 272, CP) ou medicinais (art. 273, CP). ${ }^{454}$

Como exemplo a ser abordado, aponta-se o delito de incêndio (art. 250 do CP), que possibilita algumas ponderações bastante interessantes. O legislador considera típica uma figura procurando dar à conduta de "causar incêndio, expondo a vida, a integridade física ou o patrimônio de outrem" um tratamento notadamente preocupado com a perspectiva ex ante na medida em que já se antecipa ao resultado lesivo, se é que existirá. ${ }^{455}$ Note-se que o delito em comento encontra-se localizado no título "Dos Crimes contra a Incolumidade Pública", sendo que o tratamento genérico a ele dispensado permite interpretação errônea, tipificando-se conduta sem que haja verificação de riscos penalmente relevantes. ${ }^{456}$ Renato de Mello Jorge Silveira lembra, ainda, da "teratológica equiparação com a falsificação, corrupção, adulteração ou alteração de produto destinado a fins terapêuticos ou medicinais, prevista no art. 273 do CP; de medicamentos, matérias-primas, insumos farmacêuticos, os cosméticos, os saneantes, e os de uso em diagnóstico, trazidos à baila pela Lei 9.677/98”.

Já na legislação esparsa, o meio ambiente, cuja proteção remonta tempos remotos, ${ }^{457}$ mas cuja intensificação se notou a partir do século XIX, especialmente pela

\footnotetext{
${ }^{453}$ SILVEIRA, Renato de Mello Jorge. Direito penal supra-individual: interesses difusos, cit., p. 124, nota 11. O autor faz importante lembrança de que o legislador de 1984 (que reformou a parte geral do Código Penal) reconheceu o avanço de conceitos jurídicos no tempo, entendendo por bem, no item 7 da Exposição de Motivos, recomendar uma reforma da parte especial num segundo momento.

${ }^{454}$ Id. Ibid., p. 125.

${ }^{455}$ Id. Ibid., p. 124-125.

${ }^{456}$ Id. Ibid., p. 127.

${ }^{457}$ ESER, Albin. La tutela penale dell'ambiente in Germania. Trad. Catenacci. L'Indice Penale, n. 23, p. 232, 1989.
} 
edição do Rivers Pollution Act, de 1876, na Inglaterra ${ }^{458}$ e, precisamente pelo norteamericano Water pollution control act, de $1948 .{ }^{459}$ Precisamente no Brasil o tema veio tratado no Código Florestal e no Código de Caça, ambos datados de 1934, decretos 23.793 e 24.645, respectivamente, que foram atualizados, sendo substituídos pelo novo Código Florestal (Lei 4.771/65), por legislação de proteção à fauna (5.197/67), à pesca (Dec.-lei 221/67), às águas (Dec. 50.877/61) e até mesmo aos cetáceos (7.643/87). ${ }^{460}$ Com o advento da Constituição de 1988 e com normas programáticas ${ }^{461}$ de que deverá haver a defesa ambiental pelo Estado, adveio a Lei 9.605/98, instituindo dispositivos que abarcam a fauna, a flora, poluição, patrimônio urbano e cultural, além de trazer previsões quanto à administração ambiental.

Embora se tenha notado maior preocupação ambiental em termos mundiais, não se pode deixar de apontar incoerências nas legislações. Quanto à brasileira, Miguel Reale Júnior foi enfático: “(...) não só no Brasil, mas especialmente aqui, há a tendência de transformar o Direito Penal em tábua de salvação para todas as aflições. O intenso aumento do âmbito da ação estatal no campo dos interesses difusos e dos interesses coletivos tem levado, como santo remédio, a uma criminalização crescente de condutas, que de forma alguma merecem agasalho no campo penal. Essa ilusão penal, o imaginário de poder afastar, por via de ameaça criminal, fatos lesivos de qualquer quilate, decorre, de um lado, da desconfiança da sociedade em relação a si mesma, às autoridades e às normas da Administração, acreditando-se que só serão respeitadas se houver a intimidação da sanção penal. De outro lado, o intervencionismo estatal conduz, naturalmente, ao intervencionismo penal acentuado (...)". ${ }^{462}$ Tais palavras refletem perfeitamente a expansão penal no Brasil.

Postos estes esclarecimentos feitos por Miguel Reale Júnior, fica patente a tendência na opção legislativa por crimes de perigo, incorrendo no pantanoso campo da proliferação desmedida de normas, não se ponderando aspectos ex ante e ex post das situações que se deseja incriminar. O resultado é que as normas passam a perder "rigidez metodológica, caindo no vazio da determinação aleatória de crimes". ${ }^{463}$ Isso, obviamente

\footnotetext{
${ }^{458}$ SILVEIRA, Renato de Mello Jorge. Direito penal supra-individual: interesses difusos, cit., p. 134. ${ }^{459}$ COSTA JÚNIOR, Paulo José da. Direito penal ecológico. Rio de Janeiro: Forense, 1996. p. 9 e ss.

${ }^{460}$ FERREIRA, Ivette Senise. Tutela penal do patrimônio cultural. São Paulo: Ed. Revista dos Tribunais, 1995. p. 82 e ss.

${ }^{461}$ Art. 225 e seu $3^{\circ}$ e, ainda, art. 5ํㅡㄴ LXXIII, art. 23, todos da Constituição Federal.

${ }^{462}$ REALE JÚNIOR, Miguel. A lei de crimes ambientais. Revista Forense, Rio de Janeiro, v. 95, n. 345, p. 121, jan./mar. 1999.

${ }^{463}$ SILVEIRA, Renato de Mello Jorge. Direito penal supra-individual: interesses difusos, cit., p. 137.
} 
prejudica o conhecimento da ilicitude, haja vista esta falta de técnica e falta de parâmetros lógico-jurídicos para seleção de bens que devem receber proteção do ramo criminal.

Até mesmo Hassemer já pontuou que nos termos verificados o Direito Penal chega a ser contraproducente, alegando-se que "quanto mais Direito Penal do ambiente, menos proteção ambiental; quanto mais ampliarmos e agravarmos o Direito Penal do ambiente, tanto mais estaremos a dar maus passos, pois que, a persistir nessa senda, só viremos a produzir efeitos contrários aos pretendidos: ou seja, acabaremos contribuindo para uma inexorável diminuição efetiva do meio ambiente (...). ${ }^{464} \mathrm{E}$, nesse sentido, nota-se a assessoriedade administrativa do meio ambiente, sendo o Direito Administrativo auxiliar do Direito Penal. ${ }^{465}$ Há verdadeira proteção penal das decisões das autoridades administrativas por imposição de sanções penais. ${ }^{466}$ Tal fato igualmente terá plena repercussão quando pontuado juntamente à consciência da ilicitude, que deixa de ter contornos meramente penais para forçar um conhecimento administrativo pelo destinatário das normas.

Inobstante as infrações penais ambientais integrem parte da expansão penal, ainda há que se fazer menção ao direito penal econômico e tributário. Suas origens remontam ao período pós-Primeira Guerra Mundial, ${ }^{467}$ tendo ganhado mais atenção desde a crise de $1929^{468}$ e, em especial, pós-Segunda Guerra, representando "problema jurídico da

\footnotetext{
${ }^{464}$ HASSEMER, Winfried. A preservação do meio ambiente através do direito penal. Trad. Carlos Eduardo Vasconcelos, adaptada para publicação por Paulo de Souza Mendes. Revista Brasileira de Ciências Criminais, São Paulo, n. 22, p. 28, 1998. Em sentido diametralmente oposto: FREITAS, Vladimir Passos de; FREITAS, Gilberto Passos de. Crimes contra a natureza. São Paulo: Ed. Revista dos Tribunais, 2000. p. 33.

${ }^{465} \mathrm{~A}$ assessoriedade mostra-se presente, por exemplo, nos seguintes tipos penais, que exigem manifestações advindas do direito Administrativo para integrar as punições criminais: a) Art. 29. Matar, perseguir, caçar, apanhar, utilizar espécimes da fauna silvestre, nativos ou em rota migratória, sem a devida permissão, licença ou autorização da autoridade competente, ou em desacordo com a obtida: Pena - detenção, de seis meses a um ano, e multa; b) Art. 38. Destruir ou danificar floresta considerada de preservação permanente, mesmo que em formação, ou utilizá-la com infringência das normas de proteção: Pena - detenção, de um a três anos, ou multa, ou ambas as penas cumulativamente; c) Art. 55. Executar pesquisa, lavra ou extração de recursos minerais sem a competente autorização, permissão, concessão ou licença, ou em desacordo com a obtida: Pena - detenção, de seis meses a um ano, e multa; d) Art. 63. Alterar o aspecto ou estrutura de edificação ou local especialmente protegido por lei, ato administrativo ou decisão judicial, em razão de seu valor paisagístico, ecológico, turístico, artístico, histórico, cultural, religioso, arqueológico, etnográfico ou monumental, sem autorização da autoridade competente ou em desacordo com a concedida: Pena reclusão, de um a três anos, e multa, entre outros.

${ }^{466}$ SILVEIRA, Renato de Mello Jorge. Direito penal supra-individual: interesses difusos, cit., p. 139.

${ }^{467}$ DIAS, Jorge de Figueiredo; ANDRADE, Manuel da Costa. Problemática geral das infracções contra a economia nacional. In: INSTITUTO DE DIREITO PENAL ECONÔMICO E EUROPEU. FACULDADE DE DIREITO DA UNIVERSIDADE DE COIMBRA. Direito penal económico e europeu: textos doutrinários. Coimbra: Coimbra Ed., 1998. v. 1. p. 323.

${ }^{468}$ RIGHI, Esteban. Derecho penal económico comparado. Madrid. EDERSA, [s.d.]. p. 7 e ss.
} 
atualidade" ${ }^{469}$ Assim, especialmente após o VI Congresso da Associação Internacional de Direito Penal, ocorrido em 1953 em Roma, a tutela das atividades econômicas ganhou ares de neocriminalização, representando verdadeira preocupação de organismos internacionais. $^{470}$

No Brasil, pode-se dizer que a história desse tipo de criminalidade é recente, sendo a Constituição responsável por prever, no art. 170, os princípios gerais da atividade econômica, asseverando que “(...) a ordem econômica, fundada na valorização do trabalho humano e da livre iniciativa, tem por finalidade assegurar a todos existência digna, conforme os ditames da justiça social (...)”, já elencando princípios norteadores da economia. Particularmente quanto à legislação penal, merecem especial menção as Leis 7.492/86 (define crimes contra o sistema financeiro nacional), 8.137/90 (trata dos crimes contra a ordem tributária, econômica e relações de consumo), 8.176/91 (crimes contra a ordem econômica e trata, ainda, do sistema de estoques de combustíveis) e, ainda, a Lei 9.613/98 (trata dos crimes de "lavagem", ocultação de bens, direitos e valores).

Ocorre que nem sempre as leis nacionais respeitam a regra de que os crimes de perigo são meios válidos para o combate à criminalidade econômica, desde que as condutas incrimináveis sejam objetiva e claramente descritas pela lei e estejam relacionadas com interesses facilmente identificáveis. ${ }^{471}$

No Brasil verificam-se situações em que não se pode precisar exatamente o objeto de proteção, como é o caso da previsão feita pelo art. $1^{\circ}$ da Lei $9.613 / 98$ que, ao tratar sobre os crimes de "lavagem" de dinheiro, dispõe “(...) ocultar ou dissimular a natureza, origem, localização, disposição ou movimentação ou propriedade de bens, direitos ou valores provenientes, direta ou indiretamente, de crime (...)". ${ }^{472}$ Igualmente a aparente dualidade de previsões quanto à mesma conduta (bis in idem), verificável, de forma exemplificativa, nos arts. 55 da Lei $9.605 / 98^{473}$ e art. $2^{\mathrm{o}}$ de Lei 8.176/91. ${ }^{474}$ Tais artigos são

\footnotetext{
${ }^{469}$ ANDREUCCI, Ricardo Antunes. Direito penal econômico e ilícito fiscal: estudos e pareceres de direito penal. São Paulo: Ed. Revista dos Tribunais, 1982. p. 120.

${ }^{470}$ SILVEIRA, Renato de Mello Jorge. Direito penal supra-individual: interesses difusos, cit., p. 143.

${ }^{471}$ Quanto a isso, vide a Resolução $n^{o} 8$ do Colóquio realizado em 1982 pela Associação Internacional de Direito Penal, que versou sobre crimes econômicos.

${ }^{472}$ Vide, sobre o tema: BADARÓ, Gustavo Henrique Righi Ivahy. Lei n. 10.701 de 9 de julho de 2003: análise inicial das alterações da lei de lavagem de dinheiro. Boletim IBCCRIM, São Paulo, v. 11, n. 129, p. 8-9, ago. 2003.

${ }^{473}$ Art. 55. Executar pesquisa, lavra ou extração de recursos minerais sem a competente autorização, permissão, concessão ou licença, ou em desacordo com a obtida:

Pena - detenção, de seis meses a um ano, e multa.

${ }^{474}$ Art. $2^{\text {o }}$ Constitui crime contra o patrimônio, na modalidade de usurpacão, produzir bens ou explorar matéria-prima pertencentes à União, sem autorização legal ou em desacordo com as obrigações impostas pelo título autorizativo.
} 
objeto de discussões nos tribunais, onde frequentemente se aponta que devem coexistir sob o argumento que os bens jurídicos tutelados são distintos (meio ambiente $\mathrm{X}$ patrimônio da União). Diga-se que tais entendimentos diante das previsões legais fazem, obviamente, alguma confusão quanto ao que de pretende com as leis. E isso repercute diretamente quanto à consciência da ilicitude.

Precisamente quanto aos crimes tributários - Arts. $1^{0}$ e $2^{\underline{0}}$ da Lei no 8.137, de 27 de dezembro de 1990, e nos arts. 168-A e 337-A do Decreto-Lei no ${ }^{\circ}$ 2.848, de 7 de dezembro de 1940 (Código Penal) - também merecem citação dispositivos que tratam da extinção da punibilidade, lembrando-se, ainda, que o tema é tratado, muitas vezes, de forma adjacente à suspensão da pretensão punitiva estatal porquanto as normas que regulamentam ambos os institutos são elaboradas em conjunto.

Assim, considerando-se um panorama cronológico, três leis distintas alteraram a questão da extinção da punibilidade de forma inovadora, quais sejam: o artigo $2^{0}$ da Lei $\mathrm{n}^{\mathrm{o}}$ 4.729/65, o artigo 34 da Lei $\mathrm{n}^{-0}$ 9.249/95 e o artigo $9^{\text {o }}$ da Lei $\mathrm{n}^{\mathrm{o}}$ 9.964/2000. Houve, ainda, importante colaboração jurisprudencial verificada na decisão proferida no julgamento do Habeas Corpus $\mathrm{n}^{\mathrm{o}}$ 81.611, pelo plenário Supremo Tribunal Federal, oportunidade que se firmou entendimento de que apenas ocorrerá crime contra a ordem tributária após o lançamento definitivo do tributo, não se admitindo qualquer tipo de persecução penal antes de tal marco. Essa orientação também deu ensejo à elaboração da Súmula Vinculante $\mathrm{n}^{\mathrm{o}} 24$. $^{475}$

Ocorre que, quanto à suspensão da pretensão punitiva, em 2009 houve a edição de mais uma versão dos programas de parcelamento do Fisco, o chamado "Refis IV" (também conhecido como Refis da Crise) por meio da Lei 11.941/09, que tratando parcialmente do tema extinção da punibilidade, revogou tacitamente a Lei $\mathrm{n}^{-} \mathrm{0}$ 10.684/03. Esta última tratava da suspensão da pretensão punitiva pelo parcelamento do débito tributário sendo que a outra, que lhe sucedeu e editada em 2009, não abordou a questão da extinção da punibilidade pelo pagamento direto e integral sem adesão a qualquer regime de

Pena: detenção, de um a cinco anos e multa.

$\S 1^{\underline{0}}$ Incorre na mesma pena aquele que, sem autorização legal, adquirir, transportar, industrializar, tiver consigo, consumir ou comercializar produtos ou matéria-prima, obtidos na forma prevista no caput deste artigo.

${ }^{475}$ Sobre o tema, vide GRECO FILHO, Vicente. Tipicidade, bem jurídico e lavagem de dinheiro. In: COSTA, José de Faria; SILVA, Marco Antonio Marques da (Coords.). Direito penal especial, processo penal e direitos fundamentais: visão luso-brasileira. São Paulo: Quartier Latin, 2006. Vide, ainda, PASCHOAL, Janaína Conceição. A constituição do crédito tributário, a consumação do crime tributário e a extinção da punibilidade pela prescrição. Boletim IBCCRIM, São Paulo, v. 16, n. 194, p. 2-3, jan., 2009. 
parcelamento. Então, quanto a este ponto continuou vigorando o $\S 2^{\underline{o}}$ do $\operatorname{artigo} 9^{-}$da Lei 10.684/03 relativo ao pagamento direto, integral.

Nesse contexto, em 25 de fevereiro de 2011, foi promulgada a Lei $\mathrm{n}^{\mathrm{o}}$ 12.382/11, que alterou, na prática, a hipótese de pagamento quanto a dívidas parceladas. A questão é que tal inovação faz menção ao artigo 34 da Lei no 9.249, de 26 de dezembro de 1995, possibilitando-se interpretação de que o art. 34 fora repristinado. ${ }^{476}$ Verifica-se, pois, que os referidos diplomas trataram de questões diversas, sendo um relativo ao pagamento direto (disciplinado na Lei $\mathrm{n}^{\mathrm{o}} 10.684 / 2003$ ) e outro relativo ao pagamento resultante de parcelamento (agora regrado pela Lei $\mathrm{n}^{\mathrm{0}}$ 12.382/11).

Frise-se, pois, que se o objetivo da Lei $\mathrm{n}^{\mathrm{o}}$ 12.382/11 era modificar o regime da matéria como um todo, deveria, necessariamente, alterar de forma expressa as Leis $\mathrm{n}^{\mathrm{o}}$ 10.684/03 e 11.941/09 ou promulgar uma nova lei que tratasse especificamente do assunto, desde que não fizesse referência a dispositivos legais que não possuem mais validade. Contudo, diante da patente falta de tecnicismo na redação deste novo diploma legal, entende-se que o artigo $9^{\circ}, \S 2^{\underline{o}}$, da Lei $n^{\circ} 10.684 / 2003$ deverá permanecer em vigor, ou seja, o pagamento integral (principal mais acessório), à vista, com intuito de extinguir a punibilidade, ainda poderá ser realizado a qualquer tempo.

Deve-se destacar que o efeito relevante que se pode extrair da Lei $\mathrm{n}^{\mathrm{o}}$ 12.382/2011 é o de que estará suspensa a pretensão punitiva do Estado referente aos crimes tributários, durante o período em que a pessoa física ou a pessoa jurídica relacionada com o agente dos aludidos crimes estiver incluída no regime de parcelamento, desde que o pedido de parcelamento tenha sido formalizado antes do recebimento da denúncia criminal, ou seja, da efetiva instauração do processo penal.

Diante do exposto, cabe-nos interpretar que a Lei $n^{0}$ 12.382/11 altera a extinção da punibilidade dos crimes de ordem tributária apenas e tão somente nas hipóteses envolvendo parcelamento do débito, não tendo eficácia nas questões cuja extinção da punibilidade é alcançada em razão do pagamento à vista, direto $\left(\S 2^{\mathrm{o}}\right.$ do $\operatorname{art.} 9^{\mathrm{o}}$ da Lei $10.684 / 2003)$.

Logo, tem-se que a extinção da punibilidade se dá por dois meios: (i) ao término do pagamento do parcelamento dos tributos devidos (desde que a efetiva adesão ao programa

\footnotetext{
${ }^{476}$ Este artigo havia sido revogado pelo $\S 2^{2}$, do art. $9^{\circ}$, da Lei $n^{-0} 10.684 / 2003$, que por sua vez, entende-se que não se revoga pela Lei $\mathrm{n}^{\mathrm{0}}$ 12.382/2011.
} 
preceda o recebimento da denúncia criminal) ou; (ii) por seu pagamento integral, à vista. Entretanto, diferentemente do tratamento dado ao parcelamento, na segunda hipótese o legislador não delimitou lapso temporal e, assim sendo, persiste o entendimento de que a quitação, dessa forma (à vista), poderá ser realizada em qualquer momento processual, transmutando-se sempre em causa extintiva da punibilidade. Mencionada a problemática acima é fácil identificar a dificuldade em conhecer a ilicitude relativa aos crimes tributários.

Ao lado do direito penal econômico e tributário também há os delitos relacionados à proteção do consumidor numa relação bastante clara com a expansão penal, tendo sido, desde seu aparecimento na Constituição de 1988, alvo de estudos e críticas. ${ }^{477}$ A Constituição não só previu os direitos do consumidor no art. $5^{\circ}$, XXXII, como também determinou, no art. 170, V, que a defesa do consumidor seja um dos princípios da ordem econômica nacional. Aliás, não se pode negar que o direito do Consumidor tenha caráter econômico, que nele não se esgota, tendo-se que levar em consideração outras características psicofisiológicas, como a saúde, integridade física e moral, informação, segurança e sanidade, por exemplo. ${ }^{478}$

No Brasil, notaram-se problemas envolvendo o Código de Defesa do Consumidor Lei 8.078/90 - por causa da inflação legislativa que, ainda durante a vacatio legis do mencionado codex já havia sido parcialmente derrogada pela vigência da Lei 8.137/90, que a despeito de definir crimes contra a ordem tributária, também trouxe normas regulatórias das relações de consumo. Nesse sentido, o Código trouxe variadas disposições sobre as relações de consumo e também tipos penais - arts. 61 a 80 - sendo que a Lei 8.137/90 no seu art. $7^{0}$ também trouxe previsões penais.

Verifica-se, pois, que há, também relativamente às relações de consumo, certa confusão legislativa caracterizada não apenas pela previsão de crimes de perigo abstrato, mas justamente pelos questionamentos que podem ser feitos sobre o que se pretende proteger com as incriminações previstas, já que, da forma como se encontra positivada, é claro o descontentamento com os mecanismos destinados a assegurar proteção e segurança aos consumidores, enveredando-se para situações de "mera penalização de condutas." ${ }^{479} \mathrm{E}$ o exemplo clássico da busca desenfreada pela proteção do consumidor é a previsão feita no

\footnotetext{
${ }^{477}$ TORON, Alberto Zacharias. Aspectos penais da proteção ao consumidor. Revista Brasileira de Ciências Criminais, v. 3, n. 11, p. 80 e ss., jul./set. 1995.

${ }^{478}$ SILVEIRA, Renato de Mello Jorge. Direito penal supra-individual: interesses difusos, cit., p. 148.

${ }^{479}$ Id. Ibid., p. 150.
} 
inciso IX do art. $7^{\underline{0}}$ de Lei 8.137/90 que dispõe ser crime a conduta de vender, ou expor à venda ou, de qualquer forma, entregar matéria-prima ou mercadoria em condições impróprias ao consumo.

Tal vagueza quanto ao que se deseja reprovar fica evidenciada quando se passa a questionar situações de impropriedade ao consumo, haja vista que isso não significa, necessariamente, que exista nocividade ao consumidor. E, ainda é preciso lembrar que, quanto a isso, o art. 62 do Código de Defesa do Consumidor já havia sido vetado sob o argumento de violação ao princípio da legalidade e da taxatividade. Quanto a isso, a doutrina já havia tecido considerações, especialmente quanto às violações à legalidade, como foi o caso de Paulo José da Costa, que já questionava: "como fazer para estabelecer que o produto ou o serviço são impróprios?". Isto porque a redação vetada do art. 62, “caput” do Código de Defesa do Consumidor dispunha: “(...) colocar no mercado, fornecer ou expor para fornecimento produtos ou serviços impróprios." Ora, mais do que saber o que se entenderia por "impróprio", como desejar que se tivesse conhecimento da ilicitude se, num mesmo ano, vetou-se primeiro e, depois se promoveu a positivação de norma sobre a impropriedade de produto ou serviço de forma pouco precisa?

Toda a desorganização promovida pelo Legislativo aliada à falta de critérios para incriminações fez com que se dificultasse o conhecimento da ilicitude. Verifica-se, em última análise, que a defesa do consumidor é algo louvável, desejável e até mesmo necessária nas sociedades pós-industriais, ${ }^{480}$ não se negando que, por vezes, haja incriminação de certas condutas. O ponto fulcral de ponderações será como o sistema fará proteger o consumidor e, ainda, a seletividade das condutas que pretensamente ofendem o consumidor.

Quanto aos gestores atípicos da moral - fenômeno caraterístico das sociedades pósindustriais - tem-se que, originariamente eram oriundos de classes burguesas conservadoras, mas cujo panorama foi alterado para que passasse a ser formada por outras classes sociais, como organizações ecológicas, pacifistas, raciais, feministas e outras, exercendo forte influência junto ao Estado, muitas e muitas vezes pecando pela falta de cientificidade em suas postulações, sendo representações de interesses mais políticos, nem

\footnotetext{
${ }^{480}$ CAPPELETTI, Mauro. O acesso dos consumidores à justiça. In: TEIXEIRA, Salvio de Figueiredo (Org.). As garantias do cidadão na justiça. Saraiva: São Paulo, 1993. p. 309. O autor entende que a proteção ao consumidor, feita de forma inteligente, pode ser mecanismo para restabelecer o equilíbrio entre as partes na relação de consumo, provendo ao produtor um estímulo e, ao consumidor, incrementando a capacidade de escolha.
} 
sempre permeados pela boa técnica. Não que os interesses defendidos ou pleiteados por tais grupos não sejam legítimos (porque talvez o sejam na maioria dos casos), mas sua implementação social não pode passar por alterações no ramo penal de forma indiscriminada, sem técnica, numa busca a qualquer custo por fazer valer um valor entendido como direito. Então o termo "gestores atípicos da moral" não deve ser tachado de preconceituoso, pois o que se pretende ao discorrer sobre o mesmo não é a rejeição de manifestações legítimas verificadas num Estado plural, mas apenas alertar para os deletérios efeitos que afrontem os tão caros princípios básicos do Direito Penal. ${ }^{481}$

Assim, verificou-se nos idos da década de 90, precisamente em 1994, a alteração promovida na lei dos crimes hediondos (8.072/90) para que incluísse entre o rol de crimes lá previstos o de homicídio, num claro movimento legislativo decorrente de manifestações havidas pelo assassinato da atriz Daniela Perez, tendo por base insurgências da mídia e grupos sociais. ${ }^{482}$ Eis, então que uma lei que já havia sido editada com dispositivos que foram amplamente questionados por causa de sua violação a direitos e garantias fundamentais, especialmente pela impossibilidade de se aplicar a individualização da pena em toda a sua plenitude, foi emendada para constar, mediante a clara influência de gestores atípicos da moral, nova redação que abarcasse também o homicídio nas consequências da hediondez.

Também se pode mencionar a Lei $\mathrm{n}^{\mathrm{o}}$ 10.224/01, que alterou o Código Penal para dele fazer constar o crime de "Assédio Sexual", criminalizando a conduta de quem, valendo-se da condição de superior hierárquico, constrange alguém, no ambiente de trabalho, para obter vantagem sexual.

Particularmente nesse caso não se atentou para situação verificada reiteradas vezes, isto é, a indevida utilização do Direito Penal, seu uso como representação da suprema solução dos males existentes na sociedade, tendo-se ignorado, por exemplo, outra incriminação penal: o constrangimento ilegal (art. 146). ${ }^{483}$ Ficou patente a incriminação do

\footnotetext{
${ }^{481}$ SILVEIRA, Renato de Mello Jorge. Crimes sexuais: bases críticas para a reforma do direito penal sexual. São Paulo: Quartier Latin, 2008. p. 320. O autor, discorrendo especificamente quanto aos gestores atípicos da moral nos crimes sexuais assevera: "O termo pode ter a pecha de preconceituoso, sendo que não é de se rejeitar, em um Estado plural, o direito de vários grupos se manifestarem. À medida que acabem gerando eles criminalizações que venham a atentar contra princípios básicos do Direito Penal, utilizando-se de forma perversa da própria influência da opinião pública, percebe-se um desvirtuar de valores antes não visto na seara penal. Se isso já era tido em campo supraindividual, ainda mais em um campo que gera tanta repulsa social, qual o sexual."

${ }^{482} \mathrm{~A}$ inclusão do crime de homicídio no rol dos crimes hediondos se deu pelo advento da Lei 8.930/94.

${ }^{483}$ VALENTE, Maria Inês Trefiglio; SILVEIRA, Renato de Mello Jorge (Colabs). Críticas à lei de assédio sexual: Lei n. 10.224/01. Boletim IBCCRIM, São Paulo, v. 9, n. 103, p. 12, jun. 2001.
} 
assédio sexual pela presença dos chamados gestores atípicos da moral, que, "pretendendo fazer valer os pontos de vista de certos grupos minoritários, acaba-se por hipertrofiar o horizonte criminal com novas figuras, as quais nem sempre são necessárias. Presença marcante em várias legislações, sua influência está a viciar diversas normatizações mundo afora."

Igualmente merece citação a "Lei Maria da Penha" que, a despeito das mais variadas composições familiares verificadas na atualidade, teve como objeto de proteção apenas e tão somente a mulher, causando situações de absoluta incoerência no seio familiar. Assim, suas disposições inicialmente dirigidas à proteção das mulheres se viram em xeque quando se passou a atentar para situações em que o disparate no tratamento era claro, como nos casos de homens que eram vitimizados por mulheres, a de casais homoafetivos em cuja relação havia agressões e, ainda, a violência dirigida por um homem a um casal de filhos seus, de modo que haveria a aplicação da lei num sentido quanto ao filho e, noutro, quanto à filha. Até por isso, passou-se a fazer política criminal judicial por meio de decisões que passaram a reconhecer a aplicação da lei a vítimas de violência sexual também do sexo masculino e casais homoafetivos. ${ }^{485}$

Mais atualmente outra questão mostra-se relacionada com os gestores atípicos da moral. É o caso das proposições quanto à criminalização da homofobia. Então, no mês de julho de 2011 foi apresentada minuta de projeto de lei que define "crimes que correspondem a condutas discriminatórias motivadas por preconceito de sexo, orientação sexual ou identidade de gênero bem como pune, com maior rigor, atos de violência praticados com a mesma motivação". Um desses crimes seria o de "induzir alguém à prática de violência de qualquer natureza motivado por preconceito de sexo, orientação sexual ou identidade de gênero". ${ }^{486}$ Mais do que isso, o texto traz proposta de alterar diversos tipos penais, como o homicídio, as lesões corporais, a injúria e até mesmo a

\footnotetext{
${ }^{484}$ VALENTE, Maria Inês Trefiglio; SILVEIRA, Renato de Mello Jorge (Colabs). op. cit.

${ }^{485}$ SOARES, Bárbara Musumeci. Mulheres invisiveis: violência conjugal e as novas políticas de segurança. Rio de Janeiro: Civilização Brasileira, 1999. Desde o início da vigência de lei já se notavam decisões judiciais ampliando o objeto da mesma. É o que se verifica nas matérias veiculadas em LEI Maria da Penha é aplicada para proteger homem. Conjur. Disponível em: <http://www.conjur.com.br/2008-out30/lei_maria_penha_aplicada_proteger_homem>. Acesso em: 12 out. 2011 e, ainda LEI Maria da Penha vale para relação homoafetiva. Disponível em: <http://www.conjur.com.br/2011-abr-20/lei-maria-penhaaplicada-acao-envolvendo-casal-homossexual $>$. Acesso em: 12 out. 2011. Vide, ainda, matéria veiculada em LEI Maria da Penha pune também as mulheres. Correio Braziliense. Disponível em: $<$ http://www.correiobraziliense.com.br/app/noticia/brasil/2010/02/21/interna_brasil,174867/index.shtml>. Acesso em: 12 out. 2011.

${ }^{486} \mathrm{~A}$ minuta do novo projeto de lei que trata da criminalização da homofobia é de autoria da Senadora Marta Suplicy, e o texto visa à substituição do Projeto de Lei da Câmara (PLC) 122/2006, de autoria da exdeputada Iara Bernardi, do qual Marta é relatora.
} 
quadrilha, todos no Código Penal, entre outras disposições, inserindo neles situações que narrem alguma afronta aos direitos homoafetivos. ${ }^{487}$

Eis, então, a apresentação, por meio de exemplos, de situações que indicam o fenômeno da expansão do Direito Penal no Brasil e que certamente implicam importantes

${ }^{487}$ O CONGRESSO NACIONAL decreta:

Art. $1^{\underline{0}}$ Esta Lei define crimes que correspondem a condutas discriminatórias motivadas por preconceito de sexo, orientação sexual ou identidade de gênero bem como pune, com maior rigor, atos de violência praticados com a mesma motivação.

Art. $2^{\circ}$ Para efeito desta Lei, o termo sexo é utilizado para distinguir homens e mulheres, o termo orientação sexual refere-se à heterossexualidade, à homossexualidade e à bissexualidade, e o termo identidade de gênero à transexualidade e travestilidade.

Discriminação no mercado de trabalho

Art. $3^{\circ}$ Deixar de contratar alguém ou dificultar a sua contratação, quando atendidas as qualificações exigidas para o posto de trabalho, motivado por preconceito de sexo, orientação sexual ou identidade de gênero:

Pena - reclusão, de um a três anos.

$\S 1^{\circ}$ A pena é aumentada de um terço se a discriminação se dá no acesso aos cargos, funções e contratos da Administração Pública.

$\S 2^{\underline{o}}$ Nas mesmas penas incorre quem, durante o contrato de trabalho ou relação funcional, discrimina alguém motivado por preconceito de sexo, orientação sexual ou identidade de gênero.

Discriminação nas relações de consumo

Art. $4^{\circ}$ Recusar ou impedir o acesso de alguém a estabelecimento comercial de qualquer natureza ou negarlhe atendimento, motivado por preconceito de sexo, orientação sexual ou identidade de gênero:

Pena - reclusão, de um a três anos.

Indução à violência

Art. $5^{\circ}$ Induzir alguém à prática de violência de qualquer natureza motivado por preconceito de sexo, orientação sexual ou identidade de gênero:

Pena - reclusão, de um a três anos, além da pena aplicada à violência.

Art. $6^{\circ}$ O Decreto-Lei $\mathrm{n}^{\circ}$ 2.848, de 7 de dezembro de 1940 - Código Penal, passa a vigorar com as seguintes alterações:

"Art. 61.

II...

m) motivado por discriminação ou preconceito de raça, cor, etnia, religião, origem, condição de pessoa idosa ou com deficiência, gênero, sexo, orientação sexual ou identidade de gênero.

Art. 121 .

$\S 2$ …....

VI - em decorrência de discriminação ou preconceito de raça, cor, etnia, religião, origem, condição de pessoa idosa ou com deficiência, gênero, sexo, orientação sexual ou identidade de gênero. (NR)

Art. 129.

$\S 9^{\circ} \mathrm{Se}$ a lesão for praticada contra ascendente, descendente, irmão, cônjuge ou companheiro, ou com quem conviva ou tenha convivido, ou, ainda, prevalecendo-se o agente das relações domésticas, de coabitação ou de hospitalidade ou em motivada por discriminação ou preconceito de raça, cor, etnia, religião, origem, condição de pessoa idosa ou com deficiência, gênero, sexo, orientação sexual ou identidade de gênero. (NR)

Art. 140 ......

"§ $3^{0}$ Se a injúria consiste na utilização de elementos referentes a raça, cor, etnia, religião, origem, condição de pessoa idosa ou com deficiência, gênero, sexo, orientação sexual ou identidade de gênero:

Art. 288. "(NR)

Parágrafo único - A pena aplica-se em dobro, se a quadrilha ou bando é armado ou se a associação destinase a cometer crimes por motivo de discriminação ou preconceito de raça, cor, etnia, religião, origem, condição de pessoa idosa ou com deficiência, gênero, sexo, orientação sexual ou identidade de gênero.

Art. $7^{\circ}$ Suprima-se o nomem iuris violência doméstica que antecede o $§ 9^{\circ}$, do art. 129 , do Decreto-Lei $\mathrm{n}^{-}$ 2.848, de 7 de dezembro de 1940 - Código Penal.

Art. $8^{\underline{0}}$ Esta Lei entra em vigor na data de sua publicação. 
ponderações quanto ao conhecimento da ilicitude que, como se sabe, está intimamente relacionada com o instituto do erro de proibição.

Um dos aspectos mais pantanosos do fenômeno da expansão, no entanto, é a administrativização do direito penal, situação vinculada à criação legislativa de delitos de perigo, à incriminação de condutas criadoras de risco, sem esperar a produção efetiva de lesões ou de morte; e ao surgimento por obra da lei (e também por interpretações) de bens jurídicos coletivos cujos núcleos são ideias cujo mote central é a segurança. ${ }^{488}$

Ocorre que o direito penal, ao transformar-se num direito de gestão punitiva de riscos gerais, não se limitando a reagir perante um fato lesivo individualmente delimitado, administrativiza-se, perdendo importantes características outrora vislumbradas. ${ }^{489}$ Essa administrativização é um fenômeno de imensa complexidade, impedindo que se note, prima facie, qual o âmbito de atuação do direito penal e qual o do direito administrativo. Por isso, tal característica da expansão será alvo do capítulo seguinte.

\footnotetext{
${ }^{488}$ CRESPO, Eduardo Demetrio. Do direito penal liberal ao direito penal do inimigo, cit., p. 9-37.

${ }^{489}$ DONINI, M. Selettività e paradigma della teoria del reato. Rivista Italiana di Diritto e Procedura Penale, Milano, v. 40, n. 2, p. 338-394, apr./giug. 1997; CID MOLINÉ, José. Garantías y sanciones (argumentos contra la tesis de la identidad de garantías entre las sanciones punitivas). Revista de Administración Pública, n. 140, p. 140-141, 1996. HIRSCH, Hans Joachim. Acerca del estado actual de la discusión sobre el concepto de bien jurídico. In: MODERNAS tendências en la ciencia del derecho penal y en la criminología, Madrid: Universidad Nacional de Educación a Distancia, 2001. p. 371 et seq.; MÜSSIG, Bernard. Desmaterialización del bien jurídico y de la política criminal. Sobre las perspectivas y los fundamentos de una teoría del bien jurídico crítica hacia el sistema. Revista de Derecho Penal y Criminología, n. 9, p. 169 et seq., 2002.
} 


\section{A DISTINÇÃO ENTRE O DIREITO ADMINISTRATIVO SANCIONADOR E O DIREITO PENAL COMO DEMONSTRAÇÃO DA CLARA DIFICULDADE EM LIMITAR- SE A ILICITUDE PENAL}

\subsection{Considerações iniciais}

Uma das questões chave que se pode pontuar sobre a consciência da ilicitude diante da expansão do direito penal é a ponderação do que pode ser considerado proibição penal e o que representam outras proibições, advindas de outros ramos do direito.

É certo que neste trabalho já foram mencionadas algumas palavras sobre o caráter genérico ou específico da ilicitude, todavia não se mostrando suficientemente amplas as colocações, seja pela própria localização daquelas explicações, no início do trabalho, seja pela necessidade de se ampliar e aprofundar as discussões sobre a ilicitude penal e administrativo-sancionadora, o que se passa a fazer neste capítulo. Neste particular há de se buscar, em especial, a delimitação entre o direito penal e o direito administrativo sancionador que nunca estiveram presentes em nosso cotidiano de forma tão mesclada. Quanto a isso, importante consignar que apesar de avanços na busca desse limite, muito ainda há que se ponderar.

Verifica-se, pois, que a indefinição prejudica a eficaz atribuição de responsabilidade penal, contribuindo-se igualmente para a existência de uma política sancionadora descontrolada - se é que pode ser denominada "política" - com a consequente arbitrariedade penal ínsita a essa situação. Portanto, nota-se que para que tal temática seja abordada cientificamente é preciso ter em mente a tendência expansiva do ordenamento jurídico, já mencionada em capítulo anterior neste trabalho e, por outro lado, a falta de coordenação entre o direito penal e o administrativo sancionador. Afinal, a doutrina já afirmou que embora as sanções penais e administrativas convivam há algum tempo, questões quanto à sua coordenação são essencialmente novas. ${ }^{490}$

\footnotetext{
${ }^{490}$ DELMAS-MARTY, Mireille. I problemi giuridici e pratici posti dalla distinzione tra diritto penale amministrativo. Rivista Italiana di Diritto e Procedura Penale, Milano, n. 48, p. 732, 1987.
} 
Relativamente à expansão penal, é notório que tem ocupado lugar cativo nas discussões que envolvem debates político-criminais da atualidade, ainda que não se possa falar num verdadeiro consenso. Inobstante, há um inegável fenômeno que se verifica no âmbito do direito administrativo sancionador: verdadeira política de punições a condutas que podem ser reguladas administrativamente. ${ }^{491}$ Tal situação fez com que Cerezo Mir afirmasse que na Espanha é adequado falar-se numa hipertrofia penal, mas de uma hipertrofia do direito administrativo sancionador. ${ }^{492}$ Tal situação - protagonismo exacerbado do poder sancionador da Administração - também fora percebida na Alemanha especialmente a partir dos anos oitenta. ${ }^{493}$

$\mathrm{Na}$ Espanha, a mencionada hipertrofia ganhou atenção ainda na década de setenta a ponto de se levantarem discussões sobre sua constitucionalidade, alegando-se que o sistema punitivo administrativo mostrava-se tão aflitivo quanto o sistema penal, partindose de considerações com vistas a uma reorganização do direito administrativo sancionador com nuances de orientação a um direito penal mínimo. ${ }^{494}$ Assim, no final dos anos setenta a Espanha reconheceu em sua Constituição o poder sancionador da Administração como válido, e tendo o Tribunal Constitucional admitido a existência de uma tradução matizada dos direitos e garantias penais, corria-se o risco de, autorizando-se o direito administrativo sancionador naqueles termos, atribuir ao Legislativo a possibilidade de tornar desacreditadas valiosas conquistas obtidas ao longo do tempo. ${ }^{495}$ Também é de se apontar que em muitos casos as sanções administrativas podiam verificar-se mais aflitivas que a própria sanção penal. ${ }^{496}$ Por esta razão, isto é, porque muitas vezes a sanção administrativa

\footnotetext{
${ }^{491}$ SUAY RINCÓN, José. El derecho administrativo sancionador: perspectivas de reforma. Revista de Administración Pública, n. 109, p. 188, 1986. Veja-se, ainda: PARADA VÁZQUEZ, José Ramón. El poder sancionador de la Administración y la crisis del sistema judicial penal. Revista de Administración Pública, n. 67, p. 41-42, 1972; MUÑOZ CONDE, Francisco; GARCIA ARÁN, Mercedes. Derecho penal: parte general. 7. ed. rev. y puesta al día. Valencia: Tirant lo Blanch, 2007. p. 75.

${ }^{492}$ CEREZO MIR, José. Curso de derecho penal español: parte general. 6. ed. Madrid: Tecnos, 2004. v. 1, p. 52.

${ }^{493}$ MATTES, Heinz. Problemas de derecho penal administrativo: historia y derecho comparado. Traducción y notas por José Maria Rodriguez Devesa. Madrid: EDERSA, 1979. p. 50.

${ }^{494}$ RANDO CASERMEIRO, Pablo. La distinción entre el derecho penal y el derecho administrativo sancionador. Valencia: Tirant lo Blanch, 2010. p. 26.

${ }^{495}$ Id. Ibid., p. 27.

${ }^{496}$ Basta comparar a pena de demissão aplicada administrativamente e a pena (restritiva de direitos) de limitação de final de semana, aplicada criminalmente. Outro exemplo são as sanções possivelmente aplicáveis por conta da lei de improbidade administrativa, verificadas no art. 12 da Lei 8.429/92. Veja-se: “Art. 12. Independentemente das sanções penais, civis e administrativas previstas na legislação específica, está o responsável pelo ato de improbidade sujeito às seguintes cominações, que podem ser aplicadas isolada ou cumulativamente, de acordo com a gravidade do fato: (Redação dada pela Lei no 12.120, de 2009).

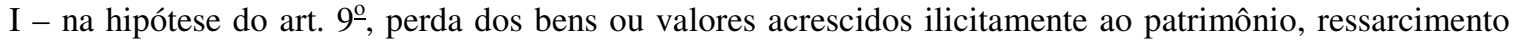
integral do dano, quando houver, perda da função pública, suspensão dos direitos políticos de oito a dez anos, pagamento de multa civil de até três vezes o valor do acréscimo patrimonial e proibição de contratar
} 
verifica-se mais grave que a penal, houve doutrina que denominasse tal situação como uma "uma fraude de etiquetas". 497

E não se pode deixar de mencionar que um dos problemas é justamente a dissonância entre as instâncias penal e administrativa, de modo que muitas vezes não se sabe exatamente quando existe a intervenção de uma ou de outra. Relativamente a um direito penal clássico, que previa delitos como o homicídio, o furto e o estelionato, atualmente há uma enormidade de tipos penais que encontram correspondentes na esfera administrativa. $^{498}$ De fato, pode-se até mesmo verificar infrações administrativas mais rigorosas que as penais, o que pode afetar, como efetivamente afeta, a segurança jurídica que deve pautar o jus puniendi, isto é, já não se terão expectativas coerentes quanto à reação do ordenamento jurídico, gerando descrédito nas instâncias de controle e, em última análise, até mesmo importantes consequências quanto ao instituto do erro de proibição. Justamente por essas razões é que se impõe a distinção entre direito penal e administrativo sancionador, porque de outra forma passará a não ter sentido a manutenção de duas instâncias de controle e, mais do que isso, restará indefinido a âmbito da ilicitude penal e administrativa. Eis, então, a justificativa deste capítulo.

com o Poder Público ou receber benefícios ou incentivos fiscais ou creditícios, direta ou indiretamente, ainda que por intermédio de pessoa jurídica da qual seja sócio majoritário, pelo prazo de dez anos;

II - na hipótese do art. 10, ressarcimento integral do dano, perda dos bens ou valores acrescidos ilicitamente ao patrimônio, se concorrer esta circunstância, perda da função pública, suspensão dos direitos políticos de cinco a oito anos, pagamento de multa civil de até duas vezes o valor do dano e proibição de contratar com o Poder Público ou receber benefícios ou incentivos fiscais ou creditícios, direta ou indiretamente, ainda que por intermédio de pessoa jurídica da qual seja sócio majoritário, pelo prazo de cinco anos;

III - na hipótese do art. 11, ressarcimento integral do dano, se houver, perda da função pública, suspensão dos direitos políticos de três a cinco anos, pagamento de multa civil de até cem vezes o valor da remuneração percebida pelo agente e proibição de contratar com o Poder Público ou receber benefícios ou incentivos fiscais ou creditícios, direta ou indiretamente, ainda que por intermédio de pessoa jurídica da qual seja sócio majoritário, pelo prazo de três anos.

Parágrafo único. Na fixação das penas previstas nesta lei o juiz levará em conta a extensão do dano causado, assim como o proveito patrimonial obtido pelo agente.”

${ }^{497}$ DELMAS-MARTY, Mireille. op. cit., p. 760.

${ }^{498}$ RANDO CASERMEIRO, Pablo. op. cit., p. 29. 


\subsection{O Direito de Intervenção e o Direito de Velocidades no contexto do Direito Administrativo Sancionador}

Não se poderia discorrer sobre o direito administrativo sancionador sem que se fizessem alguns comentários sobre duas propostas especialmente interessantes e muito debatidas, elaboradas por Winfried Hassemer e Jesús-María Silva Sánchez.

Sendo Winfried Hassemer um crítico do Direito Penal instituído sob novas concepções trazidas pela sociedade de risco, isto é, aquelas construções político-criminais destituídas de freios buscando-se primordialmente a contenção de novos riscos sociais, refletiu sobre a adequação do modelo penal aplicado neste contexto. Assim, partiu da premissa que o Direito Penal não se mostra a ferramenta adequada para exercer eficazmente o gerenciamento de riscos na sociedade pós-industrial. Por tal razão, opõe-se ao Direito Penal do risco, defendendo a ideia de que este ramo jurídico deve se circunscrever à esfera nuclear mínima, constituída por delitos clássicos cujos comportamentos ilícitos voltem-se ao indivíduo, seu referencial. ${ }^{499}$ Veja-se, in verbis: "O Direito Penal deve voltar ao aspecto central, ao Direito Penal Formal, a um campo no qual pode funcionar, que são os bens e direitos individuais, vida, liberdade, propriedade, integridade física, enfim, direitos que podem ser descritos com precisão, cuja lesão pode ser objeto de um processo penal normal. (...) Acredito que é necessário pensarmos em um novo campo do direito que não aplique as pesadas sanções do direito penal, sobretudo as privativas de liberdade e que, ao mesmo tempo, possa ter garantias menores. Eu vou chamá-lo de Direito de Intervenção". 500

Nota-se, portanto, que Hassemer propõe que os novos interesses sociais criminalmente considerados sejam objeto de novo ramo do Direito, isto é, o Direito de Intervenção, a situar-se entre os direitos civil ou administrativo e o penal. ${ }^{501}$ Isto faria com que inexistisse tratamento rigoroso demais para os interesses peculiares da pósmodernidade, auxiliando na descriminalização de condutas. Para tanto, seria necessária uma intensificação com vistas a impedir a falta de efetividade punitiva dos ramos civil e

\footnotetext{
${ }^{499}$ HASSEMER, Winfried. História das ideias penais na Alemanha do pós-guerra. Trad. Carlos Eduardo Vasconcelos. Revista Brasileira de Ciências Criminais, São Paulo, v. 2, n. 6, p. 36, abr./jun. 1994.

${ }^{500}$ Id. Perspectivas de uma moderna política criminal, cit., p. 41-51. SOUZA, Luciano Anderson de. Direito penal econômico: fundamentos, limites e alternativas. São Paulo: Quartier Latin, 2012. p. 129-132.

${ }^{501}$ SOUZA, Luciano Anderson de. op. cit., p. 130.
} 
administrativo, sendo que, por outro lado, restaria vedada a aplicação de penas privativas de liberdade. Este seria "o preço pago pela mitigação do garantismo". 502

A proposição de Hassemer, embora inovadora e cujo respeito e crédito devem ser mencionados, peca, todavia, por não se mostrar precisa. $\mathrm{O}$ autor não delineou os contornos do novo ramo de forma prática, sendo que "o ideal proposto permanece vago, sem maior concretude, perdendo força por carência de uma delimitação mais aprofundada". ${ }^{503}$ Por isso Bottini assevera que "ainda que se apresente como uma alternativa viável de organização legislativa, não nos parece suficientemente amadurecida para ser aplicada ao direito brasileiro. A falta de precisão dos contornos do direito de intervenção, assumida por Hassemer, poderia ensejar a prática de arbitrariedades, em nome da contenção eficaz de riscos. A exclusão da pena de prisão não significa que as demais sanções possam ser aplicadas sem uma sistemática rígida, que respeite o princípio da legalidade e do devido processo legal. Para isso, faz-se necessária uma discussão mais profunda e reflexiva sobre os parâmetros para a incidência das normas de intervenção, sobre os limites da flexibilidade deste sistema e sobre as condutas sobre as quais suas normas são aplicadas". 504

Curiosamente, Silva-Sánchez, um dos críticos de Hassemer por sua proposta criadora de duas classes de Direito Penal, apresentou teoria semelhante à do autor alemão. ${ }^{505}$ Ocorre que o professor de Barcelona entende que as dificuldades advindas da pós-modernidade ainda se encontram dentro dos limites de atuação do Direito Penal que, todavia, deveria ser bipartido. ${ }^{506}$ Neste sentido, para questões relativas aos direitos difusos um Direito Penal mais flexível, menos garantista e que não cominasse penas privativas de liberdade,mas penas restritivas de direito e pecuniárias, seria o adequado; por outro lado, para os interesses clássicos relacionados aos bens jurídicos individuais prevaleceria a vertente garantista com o seu peculiar rigor, a prisão. ${ }^{507}$ Eis as duas velocidades do Direito Penal, solução dualista que manteria a capacidade intimidatória inerente a este ramo sem,

\footnotetext{
${ }^{502}$ SOUZA, Luciano Anderson de. op. cit., p. 131.

${ }^{503}$ Id., loc. cit.

${ }^{504}$ BOTTINI, Pierpaolo Cruz. Crimes de perigo abstrato e princípio da precaução na sociedade de risco, cit., p. 100-101. No mesmo sentido, BECHARA, Ana Elisa Liberatore Silva. Da teoria do bem jurídico como critério de legitimidade do direito penal. 2010. Tese (Livre-docência) - Faculdade de Direito da Universidade de São Paulo, São Paulo, 2010. p. 223, nota 45.

${ }^{505}$ Tal crítica também foi feita por BOTTINI, Pierpaolo Cruz. op. cit., p. 100-101.

${ }^{506} \mathrm{O}$ autor é claro, ao mencionar que "não haveria nenhuma dificuldade em admitir esse modelo de menor intensidade garantística dentro do Direito Penal, sempre e quando - isso sim - as sanções previstas para os ilícitos correspondentes não fossem de prisão". SILVA SÁNCHEZ, Jesús-María. A expansão do direito penal: aspectos da política criminal nas sociedades pós-industriais, cit., p. 184.

${ }^{507}$ Id. Ibid., passim.
} 
todavia, sacrificar direitos individuais. Por isso mesmo afirma Silva Sánchez que "nem em todo sistema jurídico deve haver as mesmas garantias, nem em todo o sistema do Direito sancionatório tem de haver as mesmas garantias, nem sequer em todo o sistema sancionatório penal há que se exigirem as mesmas garantias, pois as consequências jurídicas são as substancialmente diversas (também no seio do próprio sistema do Direito Penal em sentido estrito)", 508

Ocorre que a proposta de Silva Sánchez, nas palavras de Bechara, "constitui um discurso eufemista, que, mediante a troca de rotulagem, acaba por pretender a justificação da flexibilização da intervenção estatal repressiva, convertendo-se em instrumento autoritário de controle social". ${ }^{509}$ Ademais, Costa igualmente tece críticas ao mencionado autor afirmando que "o mais grave defeito de sua proposta repousa em identificar a aplicação da pena privativa de liberdade com o sistema de garantias do direito penal. As garantias do direito penal não têm fundamento apenas no fato de que por seu intermédio pode-se aplicar a pena privativa de liberdade. Tais garantias se dirigem a todo o sistema penal, que de forma global representa um ataque aos direitos fundamentais". 510

Frise-se, ainda, que Silva Sánchez, na segunda edição de sua obra sobre a expansão do Direito Penal, a única traduzida ao português, menciona uma possível terceira velocidade, identificada por um direito penal de emergência, próximo ao direito penal do inimigo. 511 De fato, admite que "existe já, em ampla medida, no Direito Penal socioeconômico" e que "constatada a existência real de um Direito Penal de tais características - sobre o que não parece haver dúvida alguma -, a discussão fundamental versa sobre a legitimidade do mesmo. Certamente ela teria que se basear em considerações de absoluta necessidade, subsidiariedade e eficácia, em um contexto de emergência. Mas, remanesce a questão conceitual se, então, o Direito Penal do Inimigo persiste sendo 'Direito' ou se é já, ao contrário, um 'não Direito', uma pura reação defensiva de fato

\footnotetext{
${ }^{508}$ SILVA SÁNCHEZ, Jesús-María. A expansão do direito penal: aspectos da política criminal nas sociedades pós-industriais, cit., p. 180.

${ }^{509}$ BECHARA, Ana Elisa Liberatore Silva. Delitos de acumulação e racionalidade da intervenção penal. Boletim do IBCCRIM, São Paulo, n. 208, p. 3-5, mar. 2003. No mesmo sentido, COSTA, Helena Regina Lobo da. Proteção penal ambiental: viabilidade, efetividade, tutela por outros ramos do direito. São Paulo: Saraiva, 2010. p. 192.

${ }^{510}$ COSTA, Helena Regina Lobo da. op. cit., p. 214.

${ }^{511}$ SILVA SÁNCHEZ, Jesús-María. A expansão do direito penal: aspectos da política criminal nas sociedades pós-industriais, cit., 193;JAKOBS, Günther; CANCIO MELIÁ, Manuel. Derecho penal del enemigo, cit.; CRESPO, Marcelo Xavier de Freitas. Direito penal do inimigo: sobre o que estamos falando?, cit., p. 3; GRECO, Luís. Sobre o chamado direito penal do inimigo. Revista da Faculdade de Direito de Campos, ano 6, n. 7, dez. 2005.
} 
perante sujeitos "excluídos"".512 Conforme se pode notar, não se trataria, esta terceira velocidade, da aplicação de um direito administrativo sancionador.

Em suma, nota-se, pois, que as ideias de Hassemer e Silva Sánchez têm ponto comum, especialmente notado quanto à não utilização da sanção prisional. Afastam-se, por outro lado, quanto à sua essência, pela proposta deste de manter-se a tutela de bens difusos no âmbito criminal enquanto a do alemão propugna um patamar mínimo do Direito Penal, criando um outro ramo jurídico para o tratamento de questões relativas à pós-modernidade. Neste ponto é fundamental frisar que ambas as teorias podem ser, de alguma forma, resumidas no que se convencionou chamar de direito administrativo sancionador.

Quanto à temática no Brasil, é preciso ressaltar que as principais ideias no âmbito do Direito Administrativo Sancionador são devidas a Miguel Reale Júnior, Eduardo Reale Ferrari e a Helena Regina Lobo da Costa, além de Fabio Medina Osório. ${ }^{513}$

Pode-se dizer que seus pensamentos adotam coerência metodológica liberal, mas, especialmente, são dotados de consciência de que o Direito Administrativo Sancionador é algo que se encontra ainda em formação, cuja adoção levará a importantes consequências aos limites até hoje conhecidos e debatidos do Direito Penal. Então, partem da premissa de que não há diferença substancial entre as normas penais e administrativo-sancionadoras, entendendo-se pela subsidiariedade penal em face do Direito Administrativo Sancionador. ${ }^{514}$ Todavia, não bastaria a simplória sustentação de descriminalização de condutas e sua consequente transferência de tutela para o ramo Administrativo Sancionador e, realmente não é o que sustentam, pois, se assim fosse, o arbítrio estatal simplesmente mudaria de nome, até mesmo se agravando. Por tais razões os autores mencionados entendem ser necessária a utilização do Direito Administrativo aliado ao respeito a garantias individuais a alguma similitude ao Direito Penal no que se refere à sua

\footnotetext{
${ }^{512}$ SILVA SÁNCHEZ, Jesús-María. A expansão do direito penal: aspectos da política criminal nas sociedades pós-industriais, cit., p. 193.

${ }^{513}$ REALE JÚNIOR, Miguel. Despenalização no direito penal econômico: uma terceira via entre o crime e a infração administrativa? Revista Brasileira de Ciências Criminais, São Paulo, v. 7, n. 28, p. 116-129, out./dez. 1999; Id. Ilícito administrativo e jus puniendi geral. In: PRADO, Luiz Régis (Coord.). Direito penal contemporâneo: estudos em homenagem ao professor José Cerezo Mir. São Paulo: Ed. Revista dos Tribunais, 2007. p. 93-100; FERRARI, Eduardo Reale. Legislação penal antitruste: direito penal econômico e sua concepção constitucional. In: REALE JÚNIOR, Miguel; FERRARI, Eduardo Reale. Experiências do direito. Campinas: Millenium, 2004. p. 253-315; COSTA, Helena Regina Lobo da. op. cit.; OSÓRIO, Fabio Medina. Direito administrativo sancionador. São Paulo: Ed. Revista dos Tribunais, 2000. passim.

${ }^{514}$ REALE JÚNIOR, Miguel. Ilícito administrativo e jus puniendi geral, cit., p. 93 e ss.; FERRARI, Eduardo Reale. op. cit., p. 261; COSTA, Helena Regina Lobo da. op. cit., p. 202; OSÓRIO, Fabio Medina. op. cit., p. 102; RANDO CASERMEIRO, Pablo. op. cit., passim.
} 
construção, até mesmo pela criação de uma parte geral para o Direito Administrativo Sancionador.

Neste sentido, aponta-se que para o aperfeiçoamento do Direito Administrativo Sancionador seria preciso a adoção do princípio da legalidade, a flexibilização da aferição do elemento subjetivo, o estabelecimento de solidariedade entre a empresa e seus dirigentes, a fixação de normas quanto às dirimentes relacionadas à exigibilidade de conduta diversa, a previsão do erro de tipo, a individualização da sanção, a previsão de causas de extinção da punibilidade e a construção de um sistema processual adequado. ${ }^{515}$

Não obstante o posicionamento da doutrina pátria, verifica-se que a mera existência de dois entendimentos sobre como lidar com as características advindas da pósmodernidade (Direito de Intervenção e Direito de Velocidades), em especial a administrativização do Direito Penal é suficiente para reafirmar a dificuldade em se precisar o conhecimento da ilicitude penal.

\subsection{Um panorama do estado atual do debate quanto aos limites entre o direito penal $\mathrm{e}$ o administrativo sancionador}

Não é preciso mais que uma rápida análise do direito para que se note a mescla dos ramos penal e administrativo. Trata-se de problema verificado também no Brasil e que Díez Ripollés já analisou, asseverando ser evidente o fracasso dos que tentam sistematizar e interpretar as normas vigentes, verificando-se verdadeiro panorama de anarquia do direito positivo. ${ }^{516} \mathrm{O}$ autor indica que o ponto fulcral da análise deve ser observado sob o prisma político-jurídico, numa abordagem que remeta a análises de lege ferenda, não apenas de lege lata. ${ }^{517} \mathrm{~A}$ análise feita puramente sob a óptica do direito positivo é frágil na medida em que esse direito é mutante, situação que já foi nomeada até mesmo "desesperante". ${ }^{518}$ Qualquer observação feita unicamente sob o prisma do direito positivo

\footnotetext{
${ }^{515}$ Mencionando os autores pátrios e sintetizando suas propostas, vide SOUZA, Luciano Anderson de. op. cit., p. 146-155.

${ }^{516}$ DÍEZ RIPOLLÉS, José Luís. Política criminal y derecho penal: estudios. Valencia: Tirant lo Blanch, 2003. p. 73-74.

${ }^{517}$ Id. Ibid.

${ }^{518}$ MATTES, Heinz. op. cit., p. 159. Veja-se, ainda, GARCIA ALBERO, Ramón. La relación entre ilícito penal e ilícito administrativo: texto y contexto de las teorías sobre la distinción de ilícitos. In: QUINTERO OLIVARES, Gonzalo; MORALES PRATS, Fermín. El nuevo derecho penal económico: estudios penales en Memoria del professor José Valle Muñiz. Pamplona: Aranzadi, 2001. p. 299.
} 
apresentar-se-á questionável com base na constatação de que houve, nas palavras de Díez Ripollés, um imperdoável descuido desde a perspectiva de criação do direito. ${ }^{519}$ Por isso é que se afirma não haver um critério claro o suficiente, verificável entre a tutela e as consequências jurídicas uma vez que mesmo com o esforço do intérprete não se pode alcançar resultados frutíferos. ${ }^{520}$ A solução parece ser possível desde a construção de uma teoria político-criminal, isto é, com bases mínimas de racionalidade, conforme já salientado por Díez Ripollés e Prieto del Pino. ${ }^{521}$

Em suma, o enfoque político-jurídico se faz necessário para a delimitação dos ilícitos penais e administrativos e a consequência de se poder interpretar o conhecimento da ilicitude como parte integrante de elemento do crime. Enfoque este que deve centrar-se em decisões valorativas dos diferentes âmbitos - penal e administrativo - com vistas a uma aplicação prática de legislação racional. ${ }^{522}$

Pelo que se expôs até o momento, verifica-se que o tema em comento tem raízes mais fortes na política-criminal que na dogmática, embora isso não signifique uma grande explanação sobre o fenômeno. Parece ser preciso reconhecer que normalmente as relações entre o direito penal e o administrativo sancionador são feitas no âmbito da lege ferenda e que diversas soluções para a temática são apresentadas com base nas reformas legislativas. ${ }^{523}$ De fato, o que se diz é que as análises quanto às verificações sobre a ilicitude penal e administrativa são quase sempre estudadas desde o plano dos projetos de lei, e uma vez verificada a ineficácia desse método passa-se a analisar o direito posto numa análise quase estritamente positivista. ${ }^{524}$ Tal comportamento, embora possa apresentar resultados pouco frutíferos, parece ser o mecanismo disponível e que deve ser usado provisoriamente até que se articulem outros critérios mais convincentes.

Também é de se considerar que, percebida a proposta de distinção sob a óptica político-jurídica, deve-se precisar ou ao menos tentar-se precisar um enfoque, tendo-se em

\footnotetext{
${ }^{519}$ DÍEZ RIPOLLÉS, José Luís. Política criminal y derecho penal: estúdios, cit., p. 73-74.

${ }^{520}$ RANDO CASERMEIRO, Pablo. op. cit., p. 38.

${ }^{521}$ DÍEZ RIPOLLÉS, José Luís. Bien jurídico protegido en un derecho penal garantista. Jueces para la Democracia, Separata, n. 30, p. 13 e ss., nov. 1997; PRIETO DEL PINO, Ana María. El derecho penal ante el uso de información privilegiada en el mercado de valores. Cizur Menor: Thomson-Aranzadi, 2004. p. 214.

${ }^{522}$ Para maiores exposições, com riqueza de detalhes, veja-se: DÍEZ RIPOLLÉS, José Luís. La racionalidad de las leyes penales: practica y teoría. Madrid: Trotta, 2003. p. 67 e ss. Defendendo soluções políticocriminais em vez das dogmáticas, conferir, ainda, ZUÑIGA RODRÍGUEZ, Laura. Bases para un modelo de imputación de responsabilidad penal a las personas jurídicas. Navarra: Aranzadi, 2003. p. 200 e DOLCINI, Emilio. Sui rapporti fra técnica sanzionatoria penale e amministrativa. Rivista Italiana di Diritto e Procedura Penale, Milano, v. 48, p. 777 e ss. 1987.

${ }^{523}$ GARCIA ALBERO, Ramón. op. cit.

${ }^{524}$ RANDO CASERMEIRO, Pablo. op. cit., p. 41.
} 
vista que, aparentemente é sob essa óptica que se obterá a precisa distinção. Casermeiro traz precisa ponderação quanto a isso, ilustrando que muito se fala em intervenção mínima do direito penal sem que se desenvolva adequadamente tal premissa que nos levaria à obtenção prática da distinção, e segue exemplificando com outros princípios, como o da lesividade e subsidiariedade. ${ }^{525}$

Certo é que se deve, necessariamente, reconhecer e posicionar-se sobre a tutela penal de meros interesses administrativos e, ainda, sobre o âmbito de tutela do direito administrativo sancionador, pois será com base nessas tomadas de postura que se poderá desenvolver adequadamente uma proposta que seja apta a diferenciar o direito penal do administrativo sancionador, gerando, obviamente, reflexos quanto à consciência da ilicitude.

O fato é que Díez Ripollés tece considerações bastante pertinentes sobre as faces das apreciações quanto ao direito penal e administrativo, isto é, por vezes se conclui que a mescla entre a dogmática e a política criminal tem o condão de estabelecer diferenças entre os ramos do direito em comento. Por outras vezes, caso não se verifique uma conclusão convincente, então se encerra a discussão entregando ao legislador a tarefa de diferenciálos. ${ }^{526}$ Nessa perspectiva nota-se a eterna tensão entre teorias que não trazem respostas adequadas à tão buscada diferenciação entre as ilicitudes, talvez, especialmente por faltarlhes um plano mais concreto na abordagem proposta. Verifica-se que esse patamar de discussão apenas traz ínsita a polêmica sobre os princípios que devem reger as diferenciações e, considerando-se o que já foi dito sobre não haver tanto espaço para discussões no campo dos princípios, que deveria ser permeado por "enunciados éticos básicos". ${ }^{527}$ Não à toa Zuñiga Rodríguez pontua que enquanto se fala em decisões políticocriminais, pouco se avança na racionalização dos critérios para limitar as ilicitudes, devendo-se, antes de tudo, organizar o debate, para só então avançar em esfericidades. ${ }^{528}$

\footnotetext{
${ }^{525}$ RANDO CASERMEIRO, Pablo. op. cit., p. 42. Os seguintes autores tratam dos princípios retromencionados como sendo parte de política-criminal: DÍEZ RIPOLLÉS, José Luís. La racionalidad de las leyes penales: practica y teoria, cit. e ZUÑIGA RODRÍGUEZ, Laura. op. cit.

${ }^{526}$ DÍEZ RIPOLLÉS, José Luís. La racionalidad de las leyes penales: practica y teoria, cit.

${ }^{527}$ Id. Ibid., p. 111.

${ }^{528}$ ZUÑIGA RODRÍGUEZ. Laura. Politica criminal. Madrid: Colex, 2001. p. 246.
} 


\subsection{Sobre critérios de distinção}

Parece ser lugar-comum asseverar que as distinções clássicas entre a ilicitude penal e administrativa, vistas sob o manto de perspectivas clássicas, alcançaram não mais que um estado de novidades sem reais avanços práticos. Tanto isso se mostra verdadeiro, que a doutrina menciona o perigo de se "cultivar a arte pela arte" e que "os novos e refinados progressos conceituais não rendam mínima utilidade". ${ }^{529}$ Também se critica a repetição de teses anteriormente mencionadas e compiladas e até mesmo agressivamente denominadas "materiais de terceira mão", a exemplo do que retrataram Nieto García e Parada Vázquez. 530

De fato, chega-se a afirmar que muitas das doutrinas apresentadas na atualidade promoveram estudos pouco aprofundados quanto aos reais valores e substratos da doutrina clássica, suprimindo importantes aspectos. ${ }^{531}$ É o que aponta Casermeiro ao mencionar que, com resumo dos conflitos das teorias clássicas a aspectos ontológicos, promove-se verdadeiro afastamento de discussões maiores e ricas em fundamentação. ${ }^{532}$ Nesse sentido, uma simples troca do paradigma ontológico por valores culturalmente tidos como referência não leva a inovações substanciais para a resolução da problemática em questão.

O abandono da referência ontológica só poderia mesmo levar a uma substituição por outra, valorativa, de modo que isso não representa um grande avanço. ${ }^{533}$ Nesse sentido, o que fora proposto por Mayer - a adoção de referências valorativas no lugar das ontológicas - para a distinção entre o direito penal e o administrativo sancionador - não ajuda a promover avanços práticos. ${ }^{534}$ Isso não é o bastante para que se possam identificar interesses puramente administrativos em face dos penais. Afinal, ainda que se considerem os ramos aludidos como faces do jus puniendi, a assunção de posicionamento radicalmente unificador não parece ser o mais correto. ${ }^{535}$ Isto porque então seria o caso de considerar um

\footnotetext{
${ }^{529}$ SILVA SÁNCHEZ, Jesús-María. Aproximación al derecho penal contemporáneo. Barcelona: Bosch, 1992. p. 77; DÍEZ RIPOLLÉS, José Luís. La racionalidad de las leyes penales: practica y teoria, cit., p. 14.

${ }^{530}$ NIETO GARCÍA, Alejandro. Derecho administrativo sancionador. 4. ed. totalmente reformada. Madrid: Tecnos, 2005. Reimpression 2006. p. 23; PARADA VÁZQUEZ, José Ramón. El poder sancionador de la Administración y la crisis del sistema judicial penal, cit., p. 45.

${ }^{531}$ RANDO CASERMEIRO, Pablo. op. cit., p. 47.

${ }^{532}$ Id. Ibid.

${ }^{533}$ Id. Ibid., p. 50.

${ }^{534}$ Todavia, para estudo das normas de cultura em Mayer, vide, Normas jurídicas y normas de cultura, cit. Nesta obra o autor propõe que as normas formam seu conteúdo com base na cultura, trilhando conjuntamente o caminho da conservação dos usos e costumes, da moralidade.

${ }^{535}$ RANDO CASERMEIRO, Pablo. op. cit., p. 51.
} 
único sistema punitivo em vez de um desdobramento, o que seria - nessa perspectiva desnecessário.

Em suma, a variedade de teorias causou um panorama de confusão sobre como deveriam se inter-relacionar os subsistemas penal e administrativo. E isso mostra como é importante que se limite ou delimite os princípios básicos da intervenção penal e do direito administrativo sancionador, sendo então possível a noção da ilicitude penal e do conhecimento dela, uma vez que sua mescla só faz promover imprecisas percepções sobre seus limites.

\subsection{Algumas palavras sobre a distinção do direito penal e administrativo sancionador na Espanha}

$\mathrm{O}$ panorama quanto às diferenças entre o direito penal e o administrativo sancionador, e consequentemente o que se entende por ilicitude penal, manteve-se intacto na importação da Alemanha, feita pela Espanha. Isto é, tanto na Itália quanto na Alemanha, países onde se verificou a concessão de parte do jus puniendi ao Poder Executivo, foi possível notar critérios de distinção relativos à filosofia política e à teoria do estado partindo-se da ideia do monopólio judicial quanto ao jus puniendi. ${ }^{536}$

O pano de fundo para estas discussões se colocou da seguinte maneira: houve a preocupação de se refletir quanto a critérios para fazer aplicar uma despenalização, em especial os princípios mais caros ao Estado de Direito. Assim, pode-se afirmar que existiram verdadeiras argumentações filosóficas no âmbito do direito constitucional e da filosofia política. ${ }^{537}$ Também se afirmou que, quanto a este particular, não se pode precisar até que ponto a doutrina espanhola importou do direito comparado critérios demasiadamente abstratos, isto é, distantes de bases axiológicas e de um contexto político-jurídico. ${ }^{538}$ Isto não significa, no entanto, que a doutrina espanhola tenha deixado de lado as implicações políticoconstitucionais do problema, uma vez que autores como Parada Vásquez, Garcia de Enterria e Perez Royo já demonstravam tal preocupação na década de setenta. ${ }^{539}$ Por outro lado, talvez

\footnotetext{
${ }^{536}$ RANDO CASERMEIRO, Pablo. op. cit., p. 60.

${ }^{537}$ Id., loc. cit.

${ }^{538}$ Id. Ibid.

${ }^{539}$ É o que se verifica nas respectivas nas obras de PARADA VÁZQUEZ, José Ramón. op. cit., p. 67; Id. Evolución y constitucionalización de las infracciones administrativas. Poder Judicial, n. 4, 1982; GARCIA DE ENTERRIA, Eduardo. El problema jurídico de las sanciones administrativas. Revista Espanhola de Derecho Administrativo, Madrid, n. 10, 1976; PÉREZ ROYO, Fernando. Infracciones y sanciones tributárias. Sevilla: Instituto de Estudios Fiscales, 1972.
} 
fosse preciso ponderar se a preocupação quanto à insignificância ético-social das infrações administrativas correspondia ao panorama espanhol, encerrando-se, em suma, o posicionamento de que os critérios adotados na Alemanha nem sempre serviriam adequadamente à Espanha. ${ }^{540}$

Seria então possível aventurar-se pelas divagações de que, partindo-se de reflexões político-constitucionais o mais relevante não seria o direito administrativo tutelar interesses puramente administrativos ou que se preocupasse com crimes de perigo abstrato ou de bagatela, mas sob quais condições incidiria o direito administrativo sancionador, o que não violaria, necessariamente, o Estado de Direito. ${ }^{541}$

O fato é que a importação de uma teoria sem ponderar-se o panorama do país de destino - no caso a Espanha - pode ter sido o responsável por criar situações de bis in idem, algo comum também no Brasil, com base na adoção de posicionamento de que a administração deve cumprir seus fins mediante suas próprias sanções e que esse poder independe do poder de criar tipos penais, podendo haver dupla punição pelos mesmos fatos. $^{542}$ A doutrina entende que este problema também poderia ter sido minorado e até mesmo resolvido por mudanças simples na legislação, como a proibição de penas privativas de liberdade ou aplicações diferenciadas quanto à pena de multa. ${ }^{543}$

Então, em suma e a título de encaminhamento de raciocínio conclusivo, nota-se que quase sempre houve colisão de ideias ora defendendo a substancialidade de interesses administrativos, ora discutindo se tais interesses deveriam ser submetidos ao crivo penal ou administrativo. Deve-se, então, evitar entendimentos de que o direito penal material corresponde imediata e unicamente ao jus puniendi e, também, de que o direito administrativo sancionador corresponde ao mesmo poder atribuído ao Poder Executivo. ${ }^{544}$

\subsection{O direito administrativo sancionador como direito punitivo no direito comparado}

Aponta-se como sendo de conhecimento comum que nos países ocidentais o controle punitivo formalmente considerado é notado em duas instâncias que, apesar de

\footnotetext{
${ }^{540}$ GARCIA ALBERO, Ramón. op. cit., p. 299-300.

${ }^{541}$ Id., loc. cit.

${ }^{542}$ Id. Ibid., p. 325.

${ }^{543}$ Sugestões que seriam bem-vindas em nossa legislação e que são pontuadas por RANDO CASERMEIRO, Pablo. op. cit., p. 62.

${ }^{544}$ A propósito, vide importantes considerações em: NIETO GARCÍA, Alejandro. op. cit., p. 176-177.
} 
terem elementos próximos, apresentam características específicas diferenciadas. ${ }^{545} \mathrm{~A}$ primeira das instâncias é a penal e a segunda, em que pese alguma divergência quanto à nomenclatura, é o direito administrativo sancionador. Assim, em Portugal e na Alemanha se usa a expressão “contravenções à ordem” ao passo que na Áustria, Itália, Grécia, Dinamarca e Suécia o termo mais corrente é "direito penal administrativo", que também é o preferido em países da common law. ${ }^{546}$ Apesar de o termo empregado ser igual nos países aludidos, mesmo entre eles há algumas diferenças. Veja-se que, por exemplo, na Suécia, Dinamarca, Reino Unido e Irlanda a expressão "direito penal administrativo" representa muito mais um setor específico dentro do direito penal - como o direito penal econômico - que a ideia de poder sancionador da Administração. ${ }^{547}$ Leigh aponta que, no caso inglês, apesar de haver delitos de caráter administrativo, não há clara divisão entre as infrações penais e administrativas de modo que, antes de tudo, deve-se ter em conta que todos os ilícitos podem remeter a um procedimento penal ordinário correspondente à gravidade do fato. ${ }^{548}$ Handoll afirma que o mesmo ocorre na Irlanda, já que os tipos administrativos encontram-se subsumidos nos penais, fazendo com que não haja propriamente um sistema administrativo sancionador, mas sanções de caráter administrativo reguladas penalmente e que tomam forma pelo processo penal. ${ }^{549}$

Relativamente à Dinamarca, Greve e Gullman explicam que naquele país o sistema sempre foi uno, não havendo muito sentido em dividir-se em categorias, de modo que não há a ramificação de um "direito penal administrativo", sendo que até as infrações mais leves são penalizadas como crimes e apenas as multas de trânsito são impostas administrativamente. ${ }^{550}$

\footnotetext{
${ }^{545}$ RANDO CASERMEIRO, Pablo. op. cit., p. 69.

${ }^{546}$ Id. Ibid. Sobre o poder sancionador da administração nos Estados Unidos, veja-se: BERGER, Raoul. Administrative arbitrariness and judicial review. Columbia Law Review, n. 65, 1965; CHARNEY, Jonathan I. The need for constitutional protections for defendant in civil penalty cases. Cornell Law Review, v. 59, 1974; ABRAMS, Norman. Administrative process alternatives to the criminal process. Washington, D.C.: Law and Public Affairs Publication, National Center for Administrative Justice, 1979.

${ }^{547}$ RANDO CASERMEIRO, Pablo. op. cit., p. 70.

${ }^{548}$ LEIGH, Leonard Herschel. The system of administrative and penal sanctions. In: Europäische Kommision: the system of administrative and penal sanctions in the Member States of the European Communities. Luxemburg: National Reports, 1994. v. 1. Para um estudo ainda mais detalhado sobre as infrações administrativas, vide, do mesmo autor, Strict and vicarious liability: a study in administrative criminal law. London: Sweet and Maxwell, 1982.

${ }^{549}$ HANDOLL, John. The system of administrative and penal sanctions. In: EUROPÄISCHE KOMMISION. The system of administrative and penal sanctions in the Member States of the European Communities. National Reports. Luxemburg, 1994. v. 1.

${ }^{550}$ GREVE, Vagn; GULLMAN, Claus. The system of administrative and penal sanctions. Submitted to the EC Commission in accordance with a study contract of 19 september 1990. In: EUROPÄISCHE KOMMISION. The system of administrative and penal sanctions in the Member States of the European Communities. National Reports. Luxemburg, 1994. v. 1.
} 
Curiosamente, na Suécia boa parte das infrações administrativas existentes em outros países, como a Alemanha, Espanha e Itália, são punidas criminalmente. ${ }^{551}$ Chega-se a afirmar que o ordenamento sueco assemelha-se ao alemão, todavia muitos ilícitos alemães tidos como administrativos são reputados crimes naquele país. ${ }^{552}$ Arnholm aponta que recentemente houve a introdução de sanções administrativas para substituir o direito penal em certos casos, como o meio ambiente e a fazenda pública, mas que não devem ser tidas estritamente como punitivas. De qualquer forma, é certo que naquele país não se pode falar de um processo de despenalização por causa disso. ${ }^{553}$

Em países como a Áustria, Suíça e Grécia o poder sancionador do Estado já se mostrava presente desde o início do século XX, e, ainda que com algumas diferenças, também é o caso espanhol. ${ }^{554}$ Quanto a tudo isso, um movimento despenalizador pode ser notado por ter ocorrido paulatinamente num contexto de tentativa de solucionar a sobrecarga existente nos tribunais devido ao constante surgimento de novas infrações como consequências do reconhecimento de novos interesses sociais como dignos de proteção. ${ }^{555}$ É o que ocorreu com a Alemanha, França, Holanda, Itália e Portugal. ${ }^{556 \text { e } 557}$

De fato, foram notados os primeiros movimentos de despenalização nos anos 50, sendo que as décadas seguintes se destacaram por reafirmar o poder sancionador da Administração, até mesmo adquirindo contornos de severidade maiores que penas

\footnotetext{
${ }^{551}$ ARNHOLM, María. The system of administrative and penal sanctions in Sweden. Faculty of Law, Uppsala University, Swedish Society for European Criminal Law, 1996. p. 8.

${ }^{552}$ Id. Ibid.

${ }^{553}$ Em matéria tributária, por exemplo, a única via de reação do Estado é a cobrança de encargos, como juros e multa pelo não pagamento; relativamente ao trânsito, as sanções administrativas referem-se muito mais a questões de estacionamento, já que as demais infrações foram previstas em lei penal datada de 1951. Id. Ibid., p. 12-18.

${ }^{554}$ Sobre detalhes do poder sancionador pela Administração, veja-se MATTES, Heinz. Problemas de derecho penal administrativo: historia y derecho comparado, cit., p. 315 e ss.

${ }^{555}$ DE PALMA DEL TESO, Ángeles. El principio de culpabilidad en el derecho administrativo sancionador. Madrid: Tecnos, 1996. p. 23-28.

${ }^{556} \mathrm{Na}$ França o movimento despenalizador encontrou mais dificuldades em avançar que em outros países, sendo que o poder sancionador da Administração restou menos vigoroso, limitando-se a ilícitos contra o domínio público e contra a Fazenda. Também houve a criação de autoridades administrativas independentes, com vistas a incrementar as alterações sobre o poder sancionador estatal. Para mais detalhes, veja-se: LOZANO CUTANDA, Blanca. Panorámica general de la potestade sancionadora de Administración en Europa: "despenalización" y garantia. Revista de Administración Pública, n. 121, p. 393 e ss. e 405 e ss., 1990. Veja-se, ainda, DOMINGUEZ VILA, Antonio. Constitución y derecho administrativo sancionador. Madrid: Marcial Pons, 1997. p. 20-22. Na Holanda não há propriamente um sistema administrativo sancionador, mas em muitos casos há autoridades administrativas com poder para impor sanções. DE DOELDER, Hans. The system of administrative and penal sanctions. In: Europäische Kommision: the system of administrative and penal sanctions in the Member States of the European Communities. Luxemburg: National Reports, 1994. v. 1, p. 299-301.

${ }^{557}$ Para maior aprofundamento quanto a outros países, como Finlândia, Romênia, Israel e a antiga União Soviética, vide DELMAS-MARTY, Mireille. I problemi giuridici e pratici posti dalla distinzione tra diritto penale amministrativo, cit.
} 
impostas por tribunais penais. ${ }^{558}$ Nesse sentido, havia algo a desafiar os contornos de hipertrofia penal e da impossibilidade do Judiciário em responder à avalanche de novas infrações que o legislador havia imaginado como adequada a atender o ramo penal. ${ }^{559}$

Todas as transformações acima relatadas deram margem à progressiva implantação de leis que trasladavam infrações penais para o âmbito administrativo e/ou pretendiam estabelecer a parte geral do direito administrativo sancionador. Assim, a primeira lei geral de "contravenções" foi publicada em 1968 na Alemanha, seguida pelo movimento italiano em meados da década de setenta e do português, já no final daquela década. ${ }^{560} \mathrm{Na}$ Espanha, o estudo da temática acima abordada é mais recente, tendo-se em vista que as relações entre o direito penal e o administrativo sancionador foram influenciadas pelas idas e vindas políticas havidas no século XIX. Ademais, é de se frisar que a existência de regimes totalitários durante boa parte do século XX permitiu, em grande medida, que com a chegada da democracia surgisse um direito administrativo sancionador expandido em relação aos demais países europeus. Por isso é que se falou de uma hipertrofia do direito administrativo sancionador, a ponto de se questionar diversas normas quanto à sua constitucionalidade. ${ }^{561}$

Visto isso, parece restar claro que, apesar das diferenças entre os sistemas punitivos, a proximidade entre o Direito Penal e o Administrativo Sancionador é visível a ponto de em muitos casos haver uma mescla muito grande entre tipos penais e normas administrativas, o que, obviamente, só faz misturar os âmbitos de ilicitude, certamente influenciando no quanto é possível conhecê-la.

\footnotetext{
${ }^{558}$ DÍEZ RIPOLLÉS, José Luís. Política criminal y derecho penal: estúdios, cit., p. 21-22.

${ }^{559}$ Para uma síntese do panorama mundial, vide: LOZANO CUTANDA, Blanca. op. cit.; NIETO MARTÍN, Adán. Fraudes comunitários. Derecho penal económico europeo. Barcelona: Praxis, 1996. p. 75-78. Para aprofundamento sobre o tema na Itália, cujo auge se deu nos anos oitenta, vide: PERIS RIERA, Jaime Miguel. El proceso despenalizador. Valencia: Universidad de Valencia, 1983.

${ }^{560}$ LOZANO CUTANDA, Blanca. op. cit., p. 400-405.

${ }^{561}$ Para mais detalhes: CEREZO MIR, José. Curso de derecho penal español: parte general, cit., 6. ed., p. 52. Frise-se que o autor não se vale expressamente do termo hipertrofia do direito administrativo sancionador, mas inegavelmente retrata a desmensurada expansão administrativa.
} 


\subsection{Sobre a inexistência de uma política jurídica administrativo-sancionadora: o jus puniendi como expressão das ilicitudes penal e administrativa}

Vistos os tópicos acima se crê poder concluir que é preciso buscar um conjunto de critérios básicos de delimitação entre as ilicitudes penal e administrativo-sancionadora, mudando o enfoque normalmente dado à matéria (perspectiva político-jurídica). É chegado o momento de buscar elementos diferenciadores entre a ilicitude penal e a administrativa, avaliando-se como se inter-relacionam e como intervêm na sociedade.

Neste ponto, apesar de se pontuar que o direito penal é alvo de política criminal limitada, porque não foi possível ir muito além da enumeração de princípios básicos de intervenção, não se pode negar que isto representa um avanço considerando-se uma comparação com o direito administrativo sancionador. Há até mesmo quem afirme que esta última tem se apresentado em piores condições que o ramo penal porquanto não pode contar nem mesmo com princípios vetores como os existentes na seara penal. ${ }^{562}$

Questiona-se, assim, o objeto deste ramo do direito, se deve e quando deve intervir. E, nesse sentido, há quem diga que, não havendo por parte do direito administrativo sancionador bases político-jurídicas sólidas, dever-se-ia socorrer do direito penal para tanto, já que teoricamente é detentor de modelo mais bem delimitado. Seria importante que se pensasse, então, em critérios materiais de intervenção, que normalmente são ponderados apenas quanto ao direito penal, sendo usualmente deixados de lado quando se pensa num direito administrativo sancionador, até mesmo porque é comum falar-se em jus puniendi única a exclusivamente composto pelo direito penal. ${ }^{563}$ Outros argumentos, como o de que o direito penal é o instrumento de controle social mais assentado na consciência jurídica e também porque irradia princípios garantistas penais ao resto do ordenamento são igualmente mencionados. ${ }^{564} \mathrm{E}$ isso ocorre não porque se queira emprestar ao Direito Penal

\footnotetext{
${ }^{562}$ É o que menciona Luciano Parejo Alfonso no prólogo a DOMINGUEZ VILA, Antonio. Constitución y derecho administrativo sancionador, cit.

${ }^{563}$ Até mesmo porque o próprio direito penal apresenta vocação totalizadora do jus puniendi, e o direito administrativo é algo mais recente na história, especialmente surgindo em meados do século XX. AGUADO CORREA, Teresa. El principio de proporcionalidad en derecho penal. Madrid: Edersa, 1999. p. 31-51. Há doutrina que entende ser desejável e possível estabelecer os critérios baseados em "princípios de direito público", como o fazem NIETO GARCÍA, Alejandro. Derecho administrativo sancionador, cit. e, também, Parejo Alfonso no prólogo a DOMINGUEZ VILA, Antonio. op. cit.

${ }^{564}$ NIETO GARCÍA, Alejandro. Derecho administrativo sancionador, cit., p. 167.
} 
maior importância que os demais ramos, mas porque são os únicos princípios conhecidos como expressão do direito punitivo do Estado. ${ }^{565}$

Parece que, partindo da análise dos fundamentos do direito penal e da projeção global de seus princípios e fundamentos, se poderá chegar a critérios ou padrões básicos de intervenção que indicarão os verdadeiros limites entre a ilicitude penal e a administrativa, remetendo-nos aos patamares globais do jus puniendi. Ocorre que a temática relativa aos fundamentos do direito penal foi e ainda é objeto de constantes debates entre penalistas e, que se entende, no Brasil, deve respeitar rigorosamente a Constituição de 1988 com princípios político-criminais que possam orientar e controlar, limitando o quanto necessário, o jus puniendi. Ao se fazer isso, aparentemente, o principal problema doutrinário em busca de consenso não estará na eleição dos princípios e seus respectivos conteúdos, que detêm contornos razoavelmente claros. O problema estará centrado em um patamar acima ou anterior, isto é, em vez de se partir da vocação real do Direito Penal para que se chegue aos princípios, muitas vezes se terá procedido da forma contrária, ou seja, se partirá de princípios como o da proporcionalidade na busca de uma resposta satisfatória. ${ }^{566}$

Nesse sentido Díez Ripollés já havia dito que, analisando-se com alguma minúcia, é possível notar que predomina na doutrina enumeração pouco organizada de princípios a serem respeitados. ${ }^{567}$ Esse autor, munido de argumentos voltados à política criminal e não à dogmática, caminha para a solução ou superação dos inconvenientes acima reportados, isto é, consegue apresentar um importante modelo de intervenção penal passível de separar adequadamente diferentes âmbitos argumentativos de forma a se tornar de fundamental menção neste trabalho. Isso porque, apesar de se buscar uma classificação coerente e pormenorizada do conjunto de princípios penais, normalmente o que se verifica são comentários despidos da organização lógica necessária para a solução do problema. ${ }^{568}$

A proposta de Díez Ripollés se mostra acertada, porquanto se valendo da óptica da política criminal, apresenta modelo de intervenção penal que organiza âmbitos argumentativos distintos, que frequentemente são confundidos por outros. ${ }^{569}$ Assim, sugere

\footnotetext{
${ }^{565}$ NIETO GARCÍA, Alejandro. Derecho administrativo sancionador, cit., p. 167. O autor explica ainda que são razões de ordem cronológicas, constitucionais e dogmáticas que explicam o direito administrativo sancionador ter como ideia de fundamento o direito penal e enfatiza que não se trata de querer um simples traslado de princípios penais matizados para o âmbito do direito administrativo sancionador, mas justamente a colocação em debate de quais devem ser os princípios relativos à intervenção penal.

${ }^{566}$ RANDO CASERMEIRO, Pablo. op. cit., p. 152-153.

${ }^{567}$ DÍEZ RIPOLLÉS, José Luís. La racionalidad de las leyes penales: practica y teoria, cit., p. 131.

${ }^{568}$ Id. Ibid.

${ }^{569}$ RANDO CASERMEIRO, Pablo. op. cit., p. 153.
} 
que a racionalidade legislativa deve ser distinta daquela da aplicação do Direito, inclusive afirmando que atualmente é possível encontrar, na doutrina, uma enumeração desestruturada de princípios a serem respeitados. ${ }^{570}$ Argumenta que a racionalidade legislativa deve ser ponderada inicialmente no âmbito da filosofia do Direito, constituindo uma aplicação concreta de uma teoria de argumentação geral. ${ }^{571}$

O modelo acima aludido parte da premissa de que há cinco diferentes níveis de racionalidade, correspondentes a distintos patamares de argumentação e cuja interação deveria resultar em uma espécie de guia para tomada de decisões em matéria penal. ${ }^{572} \mathrm{Nem}$ todos têm ou terão a mesma valia na busca pela identificação das ilicitudes penal e administrativa, mas merecem ser mencionadas.

O primeiro nível é o ético, no qual se encontra boa parte dos princípios de intervenção punitiva - princípios estruturais de primeiro nível -, pois "é por meio de uma racionalidade ética que se pode observar um sistema de crenças, cultural e historicamente condicionado, que sustenta determinada coletividade". ${ }^{573}$ Esse âmbito seria abarcado, portanto, por convicções tão fortemente arraigadas na sociedade, que há doutrina entendendo ser até mesmo desnecessário discorrer sobre elas. ${ }^{574}$ Os princípios estruturais de primeiro nível seriam divididos, então, em três grandes grupos: princípios de proteção (atendendo-se as pautas limitadoras dos conteúdos de tutela penal), de responsabilidade (requisitos necessários para a atribuição de responsabilidade penal a alguém) e de sanção (fundamentos da reação estatal e as sanções em si mesmas consideradas).

O segundo nível é o teleológico, responsável por definir os objetivos a que se pretende chegar partindo-se de uma determinada política criminal. Nesse âmbito é delimitado o objeto de tutela, seu grau de proteção, os níveis de exigência, responsabilidade e sanção aplicáveis, sempre pautados pelo primeiro nível ponderado, o ético. $^{575}$

\footnotetext{
${ }^{570}$ DÍEZ RIPOLLÉS, José Luís. La racionalidad de las leyes penales: practica y teoria, cit., p. 100-105.

${ }^{571}$ Id. Ibid., p. 87.

${ }^{572}$ Esse modelo proposto por Díez Ripollés, estruturado desde os problemas penais observando-se sucessivos níveis de racionalidade tem como referência a obra de Manuel Atienza Rodriguez, embora com mudanças significativas. Veja-se: ATIENZA RODRIGUEZ, Manuel. Contribución a una teoría de la legislación. Civitas: Madrid, 1997.

${ }^{573}$ DÍEZ RIPOLLÉS, José Luís. La racionalidad de las leyes penales: practica y teoria, cit., p. 92-93 e p. 111-116.

${ }^{574}$ Id., loc. cit.

${ }^{575}$ Id. Ibid., p. 94. Com alguma calma a analisar-se o segundo nível de racionalidade se poderá concluir que é dotado de importância para a configuração das limitações entre ilicitudes penal e administrativa.
} 
Em terceiro lugar encontra-se a racionalidade pragmática, dotada da especial missão de obter os objetivos fixados anteriormente, isto é, a eficácia. Também é o âmbito de discussão sobre a possibilidade de a lei ser cumprida e aplicar as consequências jurídicas previstas. ${ }^{576}$ Trata-se de âmbito de racionalidade de fundamental importância para que se possa optar por um ou outro ramo (penal ou administrativo sancionador).

O quarto nível é o jurídico-formal, destinado e evitar que haja incoerências com outros ramos do ordenamento jurídico, e o quinto e último nível é o linguístico, perseguidor da transmissão da norma a seus destinatários especialmente por conter enunciados linguísticos compreensíveis. ${ }^{577}$

Mencionados os níveis de racionalidade, também há de se ponderar que a crise verificada no direito penal não é exclusivamente quanto à legislação, isto é, não bastará corrigir a qualidade técnica das leis para que se solucionem todos os problemas, até porque a existência das leis é um dos fatores que pode levar à consciência da ilicitude. Já dizia Atienza Rodríguez que a técnica legislativa é mais uma forma de fazer frente, com certa dignidade, à crise penal do que propriamente superá-la. ${ }^{578}$ Ademais, o fato de se querer discutir neste trabalho aspectos do conhecimento da ilicitude não exclui a possibilidade de notar e ponderar que não só estamos nos deparando com problemas cognoscíveis como também ideológicos quando se pensa na crise do ramo penal.

Nestes termos, é prudente considerar que o processo de criação das leis deve ocupar-se de observar todos os níveis de racionalidade, porque cada um deles importa consequências em forma de cascata ou degraus. Neste cenário, ponderando-se a política criminal, será melhor o que resultar maior eficiência (maximização dos conteúdos e exigências em cada nível de racionalidade).

Crê-se, assim, que a aplicação da tese acima terá importantes reflexos nas explicações sobre o conhecimento da ilicitude especialmente no sentido de, por via inversa, apresentar todas as dificuldades em delimitar-se os ramos penal e administrativo, que se possa concluir que a expansão penal realmente provocou alterações quanto ao conhecer o ilícito. Todavia, isso não significa que todos os níveis de racionalidade mencionados devam ser examinados com a mesma profundidade, objetivando-se uma definitiva diferenciação dos modelos de reprovação administrativa e penal.

\footnotetext{
${ }^{576}$ DÍEZ RIPOLLÉS, José Luís. La racionalidad de las leyes penales: practica y teoria, cit., p. 95.

${ }^{577}$ ATIENZA RODRIGUEZ, Manuel. op. cit., p. 56-57.

${ }^{578}$ Id. Ibid.
} 


\subsection{A racionalidade ética: os princípios da lesividade, fragmentariedade e a busca por uma referência ética para o Direito Penal}

\subsubsection{Sobre a lesividade}

Como dito acima, trata-se do nível ético o patamar em que se encontram os princípios de intervenção punitiva, que quando bem estruturado é capaz de sustentar a coletividade. Nesse patamar destacam-se princípios que dizem respeito a bens jurídicos e a tipos de respostas que cada sistema punitivo deve usar. Tais princípios são voltados à proteção, como se verá adiante e são, em especial, o da lesividade e o da fragmentariedade.

O princípio da lesividade deve ser destacado, porque indica o emprego dos meios punitivos do Estado às condutas que sejam socialmente danosas ou, em outras palavras, para haver a intervenção penal do Estado faz-se necessário que a conduta tenha produzido dano notado em âmbito social. Justamente é um dos princípios mais citados por não ser respeitado usualmente, tendo-se em vista condutas penalmente tipificadas que, muitas vezes, não indicam de pronto haver uma lesão. É o que ocorre frequentemente com os delitos de perigo. Por vezes, delitos materiais também se mostram na zona de penumbra existente pelas ponderações quanto ao que pode significar "lesão" e, nesses casos, há entendimentos diversos, não havendo consenso jurisprudencial. ${ }^{579}$

\footnotetext{
${ }^{579}$ Veja-se, por exemplo, o reconhecimento da insignificância no primeiro excerto abaixo colacionado, mas o não reconhecimento da tese no segundo julgado: PRINCÍPIO DA INSIGNIFICÂNCIA IDENTIFICAÇÃO DOS VETORES CUJA PRESENÇA LEGITIMA O RECONHECIMENTO DESSE POSTULADO DE POLÍTICA CRIMINAL - CONSEQUENTE DESCARACTERIZAÇÃO DA TIPICIDADE PENAL EM SEU ASPECTO MATERIAL - DELITO DE DESCAMINHO (CP, ART. 334, "CAPUT", SEGUNDA PARTE) - TRIBUTOS ADUANEIROS SUPOSTAMENTE DEVIDOS NO VALOR DE R\$ 180,58 - DOUTRINA - CONSIDERAÇÕES EM TORNO DA JURISPRUDÊNCIA DO STF - PEDIDO DEFERIDO. O PRINCÍPIO DA INSIGNIFICÂNCIA QUALIFICA-SE COMO FATOR DE DESCARACTERIZAÇÃO MATERIAL DA TIPICIDADE PENAL. - O princípio da insignificância que deve ser analisado em conexão com os postulados da fragmentariedade e da intervenção mínima do Estado em matéria penal - tem o sentido de excluir ou de afastar a própria tipicidade penal, examinada na perspectiva de seu caráter material. Doutrina. Tal postulado - que considera necessária, na aferição do relevo material da tipicidade penal, a presença de certos vetores, tais como (a) a mínima ofensividade da conduta do agente, (b) a nenhuma periculosidade social da ação, (c) o reduzidíssimo grau de reprovabilidade do comportamento e (d) a inexpressividade da lesão jurídica provocada - apoiou-se, em seu processo de formulação teórica, no reconhecimento de que o caráter subsidiário do sistema penal reclama e impõe, em função dos próprios objetivos por ele visados, a intervenção mínima do Poder Público. O POSTULADO DA INSIGNIFICÂNCIA E A FUNÇÃO DO DIREITO PENAL: "DE MINIMIS, NON CURAT PRAETOR". - O sistema jurídico há de considerar a relevantíssima circunstância de que a privação da liberdade e a restrição de direitos do indivíduo somente se justificam quando estritamente necessárias à própria proteção das pessoas, da sociedade e de outros bens jurídicos que lhes sejam essenciais, notadamente naqueles casos em que os valores penalmente tutelados se exponham a
} 
Díez Ripollés menciona que há de se considerar que certas condutas não atingem planos individuais alheios e, mesmo neles incidindo, muitas vezes configurariam atuação inerente ao convívio social, não necessitando de reprovação penal. ${ }^{580}$ Então é preciso encontrar nas condutas algum grau de lesão aos bens jurídicos ou, ao menos, exposição a perigo que não seja meramente hipotético.

O fato é que, considerando-se o direito administrativo sancionador como parte integrante do jus puniendi, então a ele seria desejável a ponderação do princípio da lesividade. De qualquer forma, a conclusão é a de que não deveria haver proibição e consequentemente sanção a condutas sem fundamento em dano social, sob pena de voltarmos à onipresente discussão sobre "proibir por proibir" ou proibir condutas fundamentalmente baseadas em aspectos da moral social, violando-se a liberdade ínsita ao Estado Democrático de Direito. ${ }^{581}$

Há, portanto, real perigo em confundirem-se as esferas punitivas, seja hipoteticamente ou mesmo na prática, porquanto a punição a condutas que atentam apenas

dano, efetivo ou potencial, impregnado de significativa lesividade. APLICABILIDADE DO PRINCÍPIO DA INSIGNIFICÂNCIA AO DELITO DE DESCAMINHO. - O direito penal não se deve ocupar de condutas que produzam resultado, cujo desvalor - por não importar em lesão significativa a bens jurídicos relevantes -não represente, por isso mesmo, prejuízo importante, seja ao titular do bem jurídico tutelado, seja à integridade da própria ordem social. Aplicabilidade do postulado da insignificância ao delito de descaminho (CP, art. 334), considerado, para tanto, o inexpressivo valor do tributo sobre comércio exterior supostamente não recolhido. Precedentes. HABEAS CORPUS nº 93482-PR. Relator: MIN. CELSO DE MELLO. DATA DE PUBLICAÇÃO DJE 06/03/2009 - ATA № 5/2009 - DJE no ${ }^{\circ} 43$, divulgado em 05/03/2009.

DIREITO PENAL. HABEAS CORPUS. CRIME DO ART. 240, $\S 2^{\circ}$ DO CÓDIGO PENAL MILITAR. PRINCÍPIO DA INSIGNIFICÂNCIA. QUESTÃO NÃO APRECIADA PELAS INSTÂNCIAS INFERIORES. IMPOSSIBILIDADE DE CONHECIMENTO PELO STF. LESÃO SIGNIFICANTE. WRIT NÃO CONHECIDO. 1. A questão de direito tratada neste writ, consoante à tese exposta pela impetrante na petição inicial, é a suposta atipicidade da conduta realizada pelo paciente, com base no princípio da insignificância, por falta de lesividade ou ofensividade ao bem jurídico tutelado na norma penal. 2. Inicialmente, considero que há obstáculo ao conhecimento do presente habeas corpus, eis que a questão do princípio da insignificância levantada pela impetrante não foi apreciada pelo Juízo de primeiro grau, nem pelo Superior Tribunal Militar, o que inviabiliza o seu conhecimento por este Supremo Tribunal Federal, sob pena de supressão de instâncias. 3. Conforme já decidiu esta Corte, "se a alegação da eventual incidência do princípio da insignificância não foi submetida às instâncias antecedentes, não cabe ao Supremo Tribunal delas conhecer originariamente, sob pena de supressão de instância" (HC 96.520/RS, Rel. Min. Cármem Lúcia, DJe 075 de 23.04.2009). 4. Ainda que superado tal obstáculo, a presente hipótese não comporta concessão da ordem. 5. No caso em tela, a lesão se revelou significante, considerando não só o valor do bem subtraído ( $\mathrm{R} \$ 490,00)$, mas também a circunstância do crime ter sido cometido no interior de unidade militar. Portanto, de acordo com a conclusão objetiva do caso concreto, entendo que não foi mínima a ofensividade da conduta do paciente, sendo reprovável o seu comportamento. 6. Ante o exposto, não conheço do habeas corpus. HABEAS CORPUS no 97254-RJ. Relator: MIN. ELLEN GRACIE. DATA DE PUBLICAÇÃO DJE 19/06/2009 - ATA № 19/2009. DJE no 113, divulgado em 18/06/2009.

${ }^{580}$ DÍEZ RIPOLLÉS, José Luís. La racionalidad de las leyes penales: practica y teoria, cit., p. 138.

${ }^{581}$ Como o caso da lei espanhola $\mathrm{n}^{\mathrm{o}}$ 16/1970 ("ley de vagos y maleantes"), que estabelecia medidas de segurança para os homossexuais, ébrios habituais e outros grupos considerados socialmente perigosos mesmo que não tivessem praticado qualquer infração. 
contra a moral ou standards sociais majoritários sobre "o certo" sem que se vinculem a verdadeiro dano, podem ser vistas como sanções a meras desobediências.

Conclui-se, portanto, que a utilização do direito administrativo com o único e exclusivo fim de corrigir o cidadão no plano ético, sem que se vincule a uma conduta externa danosa, carece de legitimação.

Então,baseado nessa conclusão, é de se ponderar que pode haver um déficit quanto ao princípio da lesividade quando aplicado pelo direito administrativo. Aparentemente se desejava reservar ao Direito Penal que se ocupasse de condutas que violem a ética, ao passo que as infrações administrativas seriam dotadas de uma indiferença ética. ${ }^{582}$ Nesse ponto Zuñiga Rodríguez já afirmou que há elementos que não podem estar no âmbito penal porque sancionam meras infrações de dever ou desobediência, os quais têm lugar natural no direito administrativo. ${ }^{583}$

É preciso mencionar, também, que as doutrinas atuais ainda se ancoram em teses de penalistas do século XIX, como Feuerbach, que recorriam ao Direito Natural para que obtivessem as ilicitudes penais das administrativas. Assim, considerava-se ilícito penal o injusto natural, e o administrativo como artificial, pensamento que também foi desenvolvido por Golsdschmidt e Wolf, que viam a infração administrativa como uma espécie de admoestação ao indivíduo descuidado, quase que uma medida disciplinar para que se lembrasse de seus deveres, mas não se configurando como reação a danos ou perigos. ${ }^{584}$ Nessa linha de raciocínio, a conclusão a que se chega é a de que os ilícitos penais deveriam ser tratados como injustos materiais com conteúdo de direito natural, ao passo que o os ilícitos administrativos têm conteúdo pautado em mera desobediência.

Tais entendimentos foram parcialmente deixados de lado, surgindo novas concepções das quais Mayer foi precursor ainda no início do século XX, entendendo haver ilícitos de direito natural - culturalmente relevantes - e ilícitos formais - culturalmente indiferentes. ${ }^{585}$ Mesmo assim, nas décadas de cinquenta e sessenta voltou-se a falar num direito penal administrativo, cujos expoentes foram Lange, Michels e Schmidt, na Alemanha; e Silva Melero, na Espanha. ${ }^{586}$

\footnotetext{
${ }^{582}$ RANDO CASERMEIRO, Pablo. op. cit., p. 169.

${ }^{583}$ ZUÑIGA RODRÍGUEZ, Laura. Bases para un modelo de imputación de responsabilidad penal a las personas jurídicas, cit., p. 201.

${ }^{584}$ Para análise mais completa do tema, veja-se MATTES, Heinz. op. cit., p. 207 e ss.

${ }^{585}$ RANDO CASERMEIRO, Pablo. op. cit., p. 175.

${ }^{586}$ Id. Ibid., p. 177.
} 
Também é preciso apontar que a doutrina menciona que ao menos na Alemanha, a legislação administrativa sancionadora é algo desvinculado do direito administrativo, de forma que o conjunto de infrações reservadas à Administração constitui um conglomerado difuso, diverso do Direito Administrativo e cujo elemento comum é a indiferença ética. ${ }^{587}$ Podem, então, existir ilícitos formalmente administrativos e materialmente administrativos, sendo que, em qualquer dos casos, falar-se-ia numa inocuidade ética, sendo, portanto, de conteúdo voltado a meras desobediências. Nesse ponto, Figueiredo Dias assevera que com a introdução de um direito de contravenções são englobados nesse novo ramo aqueles comportamentos que, apesar de axiologicamente neutros, devem ser proibidos e sancionados administrativamente. ${ }^{588}$

Impende, ainda, frisar que ao se renunciar à busca de conteúdo de injusto além da desobediência a uma norma jurídica, tem-se situação inaceitável do ponto de vista penal, uma vez que num Estado Democrático de Direito constitui uma exigência ética dotar as proibições de fundamento razoável, sempre com vistas à lesão direta ou à exposição de bem jurídico a perigo. ${ }^{589}$ A não observação de tal necessidade levaria ao que Atienza Rodriguez convencionou denominar "deformação de tipo ideológico", em que valores baseados em "respeito ao ordenamento jurídico enquanto tal" não se justificam, podendo levar a uma obediência cega das leis. ${ }^{590}$ Afinal, Welzel já afirmou que partindo-se do núcleo central do Direito Penal até chegar-se às infrações administrativas transcorre uma linha contínua, que vai se atenuando, mas que jamais desaparece. ${ }^{591} \mathrm{E}$ isso justifica a afirmação de Cerezo Mir de que muitas vezes é a distância verificada desde o ramo principal que transmite a ideia de que o injusto de determinada conduta é puramente formal. $^{592}$

\footnotetext{
${ }^{587}$ DIAS, Jorge de Figueiredo. Sobre a autonomia dogmática do direito penal econômico: uma reflexão à luz do novo direito penal económico português. Estudios Penales y Criminológicos, n. 9, p. 37-70, 1984-1985. $\mathrm{Na}$ obra o autor explica que direito penal administrativo e direito penal de contravenções são realidades materialmente distintas e não necessariamente vinculadas.

${ }^{588}$ Id. Ibid.

${ }^{589}$ Quanto ao Estado Democrático de Direito, há doutrina que o tem como pura retórica, como são os casos de PECES-BRABA, Gregorio. Los valores superiores. Tecnos: Madrid, 1984. p. 57-65, que faz ligação de valores superiores do ordenamento - como a liberdade - com o Estado Democrático de Direito; Veja-se, ainda, RANDO CASERMEIRO, Pablo. La distinción entre el derecho penal y el derecho administrativo sancionador, cit., p. 179.

${ }^{590}$ ATIENZA RODRIGUEZ, Manuel. op. cit., p. 36-37.

${ }^{591}$ Veja-se WELZEL, Hans. Derecho penal: parte general. Traduccion del aleman por Carlos Fontan Balestra. Buenos Aires: Depalma, 1956. p. 240; CEREZO MIR, José. Curso de derecho penal español: parte general, cit., 6. ed., p. 54.

${ }^{592}$ Id. Ibid.
} 
Por isso é que se diz que o legislador não pode exercer seu mister apenas com fins de doutrinar o cidadão, sancionando arbitrariamente condutas sem que haja o mínimo caráter de injusto material. ${ }^{593}$ Quando isso acontece, a noção de ilícito por parte do cidadão se perde, auxiliando que não haja referência coerente para suas ações sem que infrinja a lei, especialmente a penal.

Por outro lado, também é preciso considerar que as infrações administrativas devem ser aplicadas quando há risco de lesão ou dano a bens jurídicos, isto é, para que infrações administrativas possam ser reconduzidas ao âmbito penal é preciso que se relacionem a uma superior desobediência, como verdadeiras obstruções ou resistências que impeçam o exercício legítimo das funções de informação, vigilância e inspeção (polícia) por parte da Administração. ${ }^{594}$

Assim, ainda que não encerrada a discussão, é preciso ter em consideração os perigos em utilizar recursos linguísticos passíveis de levar a discussão ao infinito, quando, por exemplo, hipoteticamente se poderia dizer que o porte de entorpecentes para consumo próprio é uma mera desobediência, na medida que a conduta não representaria violação ética. $\mathrm{O}$ fato é que o expoente máximo da sofisticação dogmática quanto ao tema consiste em afirmar que, in casu, além da lesão/exposição a perigo da saúde pública, há igualmente desobediência ao direito. ${ }^{595}$ Isto, aliás, é parte da discussão inócua que remonta ao infinito, como acima aludido. Ora, afinal, se o que se discute é se a infração consiste em mera desobediência, então já está abandonada ao segundo plano a questão da lesividade a bem jurídico, forte indício que a punição é indevida/exagerada.

Em suma, há diversos posicionamentos sobre emprestar legitimidade a diferentes proibições, o que é um dado bastante significativo quanto à crítica retromencionada. Por todo o exposto, insta deixar patente que a postura aqui defendida é de que deve haver uma inexorável lesividade social ou exposição à lesão para que uma conduta se estime proibida e punida. O grande problema, já muito bem notado por Díez Ripollés, é determinar o que seja bem jurídico já que, segundo o autor este tem sido empregado de certo modo como "um fetiche cuja mera menção é capaz de justificar quase tudo". 596

\footnotetext{
${ }^{593}$ REBOLLO PUIG, Manuel. Potestad sancionadora, alimentación y salud pública. Madrid: Ministério para las Administraciones Públicas, 1989. p. 593. (Serie administración del Estado).

${ }^{594}$ Id. Ibid., p. 594.

${ }^{595}$ RANDO CASERMEIRO, Pablo. op. cit., p. 183.

${ }^{596}$ DÍEZ RIPOLLÉS, José Luís. La racionalidad de las leyes penales: practica y teoria, cit., p. 139-140.
} 
É inegável que, pensando num critério de lesividade,podem-se evitar dois problemas: o da punição por condutas pouco danosas ou que sejam toleradas socialmente e, ainda, a punição por condutas que representem apenas e tão somente violação ao direito vigente sob o aspecto formal.

\subsubsection{Sobre a fragmentariedade}

Pode-se dizer que a fragmentariedade ocupa papel de dupla função no âmbito do Direito Penal: seleciona os bens jurídicos mais relevantes e os protege quando deparados com condutas que os possam seriamente afrontar. Ao menos isso é o que se tem observado com frequência.

Ocorre que este é um importante princípio que, embora possa contar com diferentes opiniões doutrinárias, ${ }^{597}$ tem papel relevante na aplicação do direito penal. Assim, delimitados seus contornos, é preciso ter em conta que, apesar de importante, deve-se atentar que o desenvolvimento deficitário quanto a fatos concretos cria inconveniências para o estudo. Nesse sentido já dizia Prieto del Pino que "alguns dos princípios legitimadores da intervenção punitiva elaborados pela doutrina não passam de enunciados que carecem da concreção necessária para cumprir a missão que lhes compete, isto é, para servir de guia na tomada de decisões" e em especial para a distinção entre as ilicitudes penal e administrativa. ${ }^{598}$

\footnotetext{
${ }^{597} \mathrm{O}$ conceito já foi tratado pela doutrina como uma deficiência inevitável, mas igualmente como uma verdadeira virtude. Veja-se, sobre o tema: ZIPF, Heinz. Introducción a la política criminal. Trad. De Miguel Izquierdo Macías-Picavea. Madrid: Edersa, 1979. p. 43-44; MIR PUIG, Santiago. Derecho penal: parte general. 8. ed. Barcelona: Editorial Reppertor, 2008. p. 118-119.

${ }^{598}$ PRIETO DEL PINO, Ana María. El derecho penal ante el uso de información privilegiada en el mercado de valores, cit., p. 206. Veja-se que no julgado abaixo buscou-se dar alguma concreção à fragmentariedade pelo reconhecimento da própria irrelevância administrativa da conduta, nos termos da lei n⿳ ${ }^{0}$ 10.522/02, Art.. 20: EMENTA: HABEAS CORPUS. DESCAMINHO. MONTANTE DOS IMPOSTOS NÃO PAGOS. DISPENSA LEGAL DE COBRANÇA EM AUTOS DE EXECUÇÃO FISCAL. LEI № 10.522/02, ART. 20. IRRELEVÂNCIA ADMINISTRATIVA DA CONDUTA. INOBSERVÂNCIA AOS PRINCÍPIOS QUE REGEM O DIREITO PENAL. AUSÊNCIA DE JUSTA CAUSA. ORDEM CONCEDIDA. 1. De acordo com o artigo 20 da Lei $\mathrm{n}^{\mathrm{o}}$ 10.522/02, na redação dada pela Lei $\mathrm{n}^{\mathrm{o}}$ 11.033/04, os autos das execuções fiscais de débitos inferiores a dez mil reais serão arquivados, sem baixa na distribuição, mediante requerimento do Procurador da Fazenda Nacional, em ato administrativo vinculado, regido pelo princípio da legalidade. 2. O montante de impostos supostamente devido pelo paciente é inferior ao mínimo legalmente estabelecido para a execução fiscal, não constando da denúncia a referência a outros débitos em seu desfavor, em possível continuidade delitiva. 3. Ausência, na hipótese, de justa causa para a ação penal, pois uma conduta administrativamente irrelevante não pode ter relevância criminal. Princípios da subsidiariedade, da fragmentariedade, da necessidade e da intervenção mínima que regem o Direito Penal. Inexistência de lesão ao bem jurídico penalmente tutelado. 4. O afastamento, pelo
} 
De acordo com a fragmentariedade os limites constitucionais para imposição de pena implicam a obrigação de selecionar as condutas mais graves e a elas impor penas, sem deixar de considerar a existência de outras condutas, também graves, mas com conteúdo menos intenso que as primeiras, e que também merecem reprovação, mas não necessariamente com atuação penal por sua lesividade menos intensa. ${ }^{599}$

O entendimento de que o princípio ora em comento é dotado de aptidão para auxiliar a distinção entre as ilicitudes penal e administrativa pode ser defendido especialmente partindo-se do pressuposto de que o Direito Penal se presta ao repúdio dos ataques mais graves feitos contra aos bens jurídicos essenciais à convivência social e, ao mesmo tempo, que o direito administrativo deve se ocupar de ataques menos intensos. Esse raciocínio, no entanto, leva-nos a questões que se convencionou nomear de critério quantitativo de distinção (entre o ilícito penal e o administrativo). A conclusão a que se chega, partindo-se da ideia acima, é a de que o Direito Penal e o Administrativo têm finalidades semelhantes, diferenciando-se apenas pela importância do bem jurídico posto em jogo e a gravidade dos ataques feitos a eles. ${ }^{600}$

Pois bem. Partindo-se dessa premissa, verifica-se uma perspectiva garantista na doutrina, de modo que se pretende a máxima redução da violência na sociedade, o que se obterá pela redução do âmbito de atuação penal, na medida em que o direito penal emprega as punições mais aflitivas. ${ }^{601}$ Assim, partindo-se da noção de que o Direito Penal aplica as penas mais graves, deveria o mesmo ser destinado aos ataques mais intoleráveis aos pressupostos de convivência social, de modo que sendo tão drásticos seus meios de intervenção, que seus objetivos deveriam ser restringidos. ${ }^{602}$ É assim, então, que Ferrajoli entende que os delitos apenados com sanções pecuniárias evidenciam um defeito de punição ou um excesso de proibição, tudo com vistas a abolir penas pecuniárias do âmbito

órgão fracionário do Tribunal Regional Federal da $4^{\mathrm{a}}$ Região, da incidência de norma prevista em lei federal aplicável à hipótese concreta, com base no art. 37 da Constituição da República, viola a cláusula de reserva de plenário. Súmula Vinculante $\mathrm{n}^{\mathrm{o}} 10$ do Supremo Tribunal Federal. 5. Ordem concedida, para determinar o trancamento da ação penal. HABEAS CORPUS nº 92438-PR. Relator: MIN. JOAQUIM BARBOSA. DATA DE PUBLICAÇÃO DJE 19/12/2008 - ATA № 42/2008 - DJE nº 241, divulgado em $18 / 12 / 2008$.

${ }^{599}$ NAVARRO CARDOSO, Fernando. Infracción administrativa y delito: limites de intervención del derecho penal. Madrid: Colex, 2001. p. 25.

${ }^{600}$ DORADO MONTERO, Pedro. Voz “Codigo Penal”. In: NUEVA enciclopedia jurídica española. Barcelona: F. Seix, 1985. v. 6, p. 665-666; DEL ROSAL, Juan. Tratado de derecho penal español: parte general. 3. ed. Madrid: Aguirre, 1978. v. 1, p. 45.

${ }^{60}$ RANDO CASERMEIRO, Pablo. op. cit., p. 195.

${ }^{602}$ DÍEZ RIPOLLÉS, José Luís. La racionalidad de las leyes penales: practica y teoria, cit., p. 141. 
criminal. $^{603}$ A reação penal deve ser, então, muito grave. ${ }^{604}$ Nota-se que esse tipo de pensamento está relacionado com a fundamentação do direito penal com base nas finalidades da pena.

Precisamente neste ponto é bom que se lembre do posicionamento de Díez Ripollés, que aponta ser mais correta a abordagem feita de modo invertido, isto é, é pela gravidade dos ataques que se legitimará as duras intervenções penais e não estas que demandam limitação no âmbito de aplicação deste ramo. ${ }^{605}$ Isso leva-nos a ter em mente que o direito penal deve consubstanciar-se na tutela dos interesses fundamentais, sendo que as penas ditas aflitivas seriam apenas o meio para tanto. Em outras palavras, o controle social formal penal deve ser estruturado com base na necessidade de proteção a bens jurídicos e não na necessidade de justificar as penas. E esse tipo de mescla é que auxilia a caracterização equivocada dos âmbitos de proteção, tornando igualmente dificultoso para os cidadãos distinguirem as ilicitudes, isto é, se sua conduta é ilícita e merecedora de processo criminal e possivelmente a correspondente pena, ou se de outra forma, embora ilícita sua conduta, terá como reprovação outro tipo de punição.

Uma conclusão a que se pode chegar é a de que, ao focar as atenções nos crimes (leia-se, nas condutas) e não nas penas, não se verifica a necessidade de limitar o campo de atuação penal senão quanto aos bens jurídicos protegidos. Nesse ponto, parece correto o entendimento de que o princípio da fragmentariedade é, de fato expansivo, não limitador, especialmente no que tange às penas a serem impostas. ${ }^{606}$ Explica-se: se com base na fragmentariedade selecionam-se as condutas mais lesivas, logicamente também se lhes impõem as penas mais graves. Justamente aqui se mostra o caráter expansivo da fragmentariedade. Então é admissível entender que o caráter expansivo é, em alguma medida, enrijecedor das penas. Daí a necessidade de que haja diversos níveis de racionalidade penal.

Outro ponto que deve ser observado é o de que o uso do direito penal não deve ser visto sob a exclusiva óptica de penas graves de maneira que sanções severas podem significar relação com o direito penal, mas o contrário não é uma verdade absoluta. Afinal, o direito penal pode valer-se de penas ditas de média ou pouca severidade, sendo

\footnotetext{
${ }^{603}$ FERRAJOLI, Luigi. Derecho y razón. 4.ed. Madrid: Trotta, 2000. p. 416-418.

${ }^{604}$ Id. Ibid.

${ }^{605}$ DÍEZ RIPOLLÉS, José Luís. La racionalidad de las leyes penales: practica y teoria, cit., p. 142.

${ }^{606}$ Id. Ibid.
} 
possivelmente este um dos pontos que auxiliam a confusão entre as esferas de ilicitude penal e administrativa.

Assim, como bem apontado por Zuñiga Rodríguez, não se deve vincular o direito penal à prisão, apesar de seguir sendo a instância de controle que emprega privações de liberdade. ${ }^{607}$ Os equívocos que mesclam as ilicitudes provavelmente surgem também da tendência em comparar a pena privativa de liberdade com as multas administrativas para contrastar as instâncias punitivas. Isso faz com que, exemplificativamente, se compare um homicídio e sua punição àquela devida punição por se estacionar o automóvel em local proibido. ${ }^{608}$ Esse ponto de vista leva a mero esquivo do ponto principal do problema, deixando de lado a quantidade de bens jurídicos tutelados pelo direito penal que muitas vezes não são reconhecidos pela doutrina como sendo fundamentais. Esse posicionamento, então, absolutiza o alcance do princípio da fragmentariedade e fecha o debate sobre outros possíveis fatores que levariam à justificativa de que nem todas as infrações administrativas merecem penas menos rigorosas que as criminais.

Ainda que se afaste da concepção tradicional da gravidade das penas no âmbito criminal tem-se que a fragmentariedade seleciona os atentados mais graves ao que se reputa fundamental à convivência. Este seria o conteúdo central do dito princípio. Mas como seguir nesse labor seletivo? Isso pode ser obtido pela sua apreciação desde a perspectiva de que a elevada estima que merecem em qualquer sociedade determinados bens jurídicos, considerados fundamentais, legitima seu elevado âmbito de proteção pelo ordenamento jurídico até o ponto que o Estado esteja autorizado a impor pena aos infratores. Apenas para tais tipos de ataques aos postulados fundamentais é que se admitiria o jus puniendi. Então cabe aqui englobar a discussão no âmbito da racionalidade ética, mas com a necessidade de se analisar aspectos internos e externos de legitimação. ${ }^{609}$

A fragmentariedade deve significar que apenas os ataques mais graves e intoleráveis aos pressupostos essenciais de convivência são merecedores de punição estatal. Aqui deve-se frisar que os tais pressupostos essenciais não representam apenas e tão somente os bens nucleares, mas incluem-se aí também direitos difusos. O fato é que o direito penal não precisa assumir sozinho a missão de proteger os ataques mais graves,

\footnotetext{
${ }^{607}$ ZUÑIGA RODRÍGUEZ, Laura. Bases para un modelo de imputación de responsabilidad penal a las personas jurídicas, cit., p. 204-205. No mesmo sentido, COSTA, Helena Regina Lobo da. Proteção penal ambiental: viabilidade, efetividade, tutela por outros ramos do direito, cit., p. 214.

${ }^{608}$ Exemplo verificado em RANDO CASERMEIRO, Pablo. op. cit., p. 199.

${ }^{609}$ Id. Ibid., p. 203.
} 
podendo a Administração se valer do seu poder sancionador para intervir. Isso aponta para a direção de que ao direito penal não se deve dar a exclusividade do princípio da fragmentariedade, cabendo sua aplicação também ao direito administrativo sancionador. Assim como há ilícitos administrativos mais graves, há ilícitos penais mais brandos, não existindo uma necessária coerência na apreciação da fragmentariedade nos diferentes ramos do direito.

Em suma, parece que os penalistas fazem uso menos eficiente do que deveriam do princípio em comento, reservando-o exclusivamente ao direito penal ou quando, com base nele, se pretende distinguir as ilicitudes penais das administrativas. ${ }^{610}$ Eis o nível externo, que não deve ser usado como critério suficiente para a distinção das ilicitudes. $O$ fato é que a fragmentariedade deve ser o princípio a permitir a intervenção em face dos ataques que se revistam de certa gravidade.

Por outro lado, analisando-se um aspecto interno de legitimação, seria este o âmbito de análise do juízo de proporcionalidade entre o ilícito e a pena. ${ }^{611}$ Deve-se frisar, no entanto, que igualmente essa abordagem não fixa o momento da intervenção exclusiva do direito penal, porque deve se prestar a ser um parâmetro entre a gravidade do ataque e da consequência jurídica sem que se estabeleça um prejulgamento sobre a necessidade da conduta ser sancionada pelo ramo penal ou administrativo. ${ }^{612}$

Então, ainda que o aspecto interno entre em cena quanto à prévia decisão sobre estar-se disposto a empregar o jus puniendi, isso não significa que este aspecto seja menos relevante que o externo, retromencionado. Então, a análise interna serve para nos situar nas verdadeiras coordenadas do problema: com frequência o que importa é o grau de punição, o grau de força que o Estado possa assumir e se esta incidirá sobre a liberdade ou patrimônio dos cidadãos - discussão que pode ter maior peso que a própria eleição do ramo a ser utilizado em cada situação. ${ }^{613}$

Note-se que até então, vislumbra-se que as condutas ilícitas podem ou não receber sanções mais ou menos graves e que isso não precisa significar a escolha imediata entre

\footnotetext{
${ }^{610}$ AGUADO CORREA, Teresa. op. cit., p. 220.

${ }^{611}$ PRIETO DEL PINO, Ana María. op. cit., p. 212.

${ }^{612}$ RANDO CASERMEIRO, Pablo. op. cit., p. 210 . O autor reconhece, no entanto, que não é fácil dar concretude a essa proposta. Precisamente na p. 214 reconhece que há outros exemplos melhores, sendo aquele uma "experiência de laboratório". Então menciona a imposição de medidas civis para situações de vingança privada (algo como o exercício arbitrário das próprias razões).

${ }^{613}$ Id. Ibid., p. 211.
} 
uma ilicitude penal ou administrativa. O que certamente se mostra necessário nessa busca é um marco, uma referência ética para o Direito Penal.

\subsubsection{Sobre a busca por uma referência ética no âmbito penal}

Quanto ao marco ético, entendem-se necessárias algumas reflexões sobre o status comunicativo do Direito Penal. Não sendo o caso do Direito Penal diferenciar-se em absoluto do direito administrativo sob o aspecto do conteúdo, diz a doutrina que não haveria então qualquer obstáculo para que o ramo administrativo se colocasse à frente para a proteção de condutas como a de um homicídio doloso. ${ }^{614}$ Isso levaria - acredita-se - a uma inexorável inquietude diante da despenalização das condutas que com maior gravidade atentam contra bens jurídicos mais fundamentais. Essa despenalização não seria aceitável de plano, mas sua ocorrência poderia proporcionar efeitos práticos talvez antes não imaginados.

Imagine-se, ainda que improvável, que devido a uma especial política sancionadora da Administração se reduzisse o nível de homicídios em maior porcentagem se o âmbito de repressão estatal fosse mantido na seara penal. Imagine-se, igualmente, que essa política administrativa não significasse flexibilização dos direitos e garantias fundamentais. Estarse-ia disposto a renunciar a tutela penal dos ataques diretos à vida? A resposta intuitiva é, muito seguramente, "não". Mas a questão principal é por que se tem tão claro que a resposta é "não"?

Parece que tal rechaço seja proveniente de enunciados éticos traduzidos na necessidade de que as condutas nucleares socialmente nocivas não possam deixar de ser objeto do Direito Penal. Tal necessidade gravita em torno de elementos como o desejo de que as condutas mais danosas sejam "bem visíveis", que integrem todos um texto legal (como o Código Penal) e que, a despeito da eficácia, que haja reação mais enérgica por parte do Estado como penas nominalmente mais graves. ${ }^{615}$ Tal entendimento tem substrato em teorias retribucionistas que reconhecem uma função comunicativo-simbólica do Direito

\footnotetext{
${ }^{614}$ LASCURIÁN SÁNCHEZ, Juan Antonio. Por un derecho penal solo penal: derecho penal, derecho de medidas de seguridad y derecho administrativo sancionador. In: BAJO FERNÁNDEZ, Miguel; JORGE BARREIRO, Agustín; SUÁREZ GONZÁLEZ, Carlos (Coords.). Homenaje al Profesor Dr. Gonzalo Rodríguez Mourullo. Madrid: Civitas, 2005. p. 622.

${ }^{615}$ RANDO CASERMEIRO, Pablo. op. cit., p. 213.
} 
Penal, ou como mencionado por Díez Ripollés, "efeitos expressivos integradores do Direito Penal". 616

O fato é que a disseminação desse tipo de abordagem faria com que houvesse uma necessária ponderação quanto às condutas realmente mais graves desde a perspectiva de danosidade social. É justamente nesse ponto que outras dificuldades para o conhecimento da ilicitude se mostram presentes na medida em que a releitura quanto à gravidade das condutas importa na aceitação de que há uma exceção de proibição pela mescla e coincidência de tratamentos penais e administrativos.

Silva Sánchez já se posicionou quanto a isso, esclarecendo que em um mundo onde as dificuldades de orientação cognitiva são cada vez maiores, parece razoável a busca por elementos de orientação normativa - e dentro destes o Direito Penal ocupa um lugar de destaque - de forma quase obsessiva. ${ }^{617}$ Díez Ripollés também se manifestou quanto a novas abordagens relativas à danosidade social, produzidas por certas condutas. $\mathrm{O}$ autor ponderou que a ausência de reações próprias do controle penal poderia suscitar nos cidadãos a decisão de praticar condutas objetivamente delitivas na medida em que não as perceberiam sua relação e limites derivados do autocontrole social; também praticariam condutas que entendessem não ilícitas porquanto erroneamente assumido que houve mudanças quanto a concepções socioculturais básicas. ${ }^{618}$ Isso é uma clara demonstração de que o autor notou a possibilidade de haver maiores perspectivas de confusão entre a ilicitude penal e administrativa, interferindo no conhecimento da ilicitude e no erro de proibição.

Voltando à abordagem de danosidade social, com o tempo surgiram teorias que buscam apresentar uma referência ética para o direito penal. Uma delas é o critério puramente quantitativo, que se preocupa apenas e tão somente com a gravidade das condutas e das punições para que se distinga entre a ilicitude penal e a administrativa. Esse critério não mostrou ser detentor de concretude suficiente para garantir-lhe os louros da distinção adequada, restando clara a necessidade de retorno a um núcleo duro do direito penal para tanto. Assim, é preciso delimitar o que compõe o âmbito irrenunciável de tutela

\footnotetext{
${ }^{616}$ DÍEZ RIPOLLÉS, José Luís. El derecho penal simbólico y los efectos de las penas. Actualidad Penal, n. 1, p. 5-6 e 125, 2001. Ditos efeitos têm papel fundamental nas teorias preventivas que buscam reforçar ou confirmar a vigência dos conteúdos básicos da ordem social entre os cidadãos. $\mathrm{O}$ autor menciona, ainda, que as diferenças entre os âmbitos penal e administrativo têm relação com a repercussão comunicativosimbólica da existência de uma infração penal

${ }^{617}$ SILVA SÁNCHEZ, Jesús-María. La expansión del derecho penal. Madrid: Civitas, 2001. p. 41-42.

${ }^{618}$ DÍEZ RIPOLLÉS, José Luís. El derecho penal simbólico y los efectos de las penas, cit., p. 11.
} 
penal, uma espécie de "tábua de mandamentos fundamentais"619 que se posta sobre as ponderações puramente quantitativas, ${ }^{620}$ sendo que o núcleo duro é pautado por valores sociais e não pela eficácia. Em outras palavras, a fragmentariedade já comentada teria aqui o papel de auxiliar na seleção - com base nos bens jurídicos mais valiosos - os ataques que mais incomodam a convivência social. E o grande problema é justamente este: a correta identificação dos ataques mais graves, sendo certo que alguns valores são de mais rápida percepção, como a vida e a liberdade. Não se pode esquecer, ademais, que deveria haver critérios para dar concretude ao núcleo duro; critérios que deveriam emanar das convicções sociais mais incontrovertidas.

As observações acima fazem pressupor que o direito penal cuida - ao menos - dos bens nucleares mas, também - embora seja algo ainda controvertido - de outros bens ou interesses que gozam de alta estima social, mas cuja importância não se mostra imediatamente equivalente àqueles bens. É o caso dos ataques ao meio ambiente, à ordem tributária, aos direitos dos consumidores etc. Neste sentido há doutrina que entende ser de rigor que o direito penal fique restrito ao núcleo duro, sendo este composto pelos ataques mais intensos aos bens fundamentais, excluindo-se daí os bens transindividuais, de cuja proteção o direito penal tem se ocupado cada vez mais. Então seriam admitidos ataques menores a bens jurídicos fundamentais. Isso se partindo do princípio de que o direito penal cresceu indevidamente, expandindo-se de forma a assumir a proteção contra condutas que causam nada mais que um risco mediato e difuso para os bens fundamentais. ${ }^{621}$ Nesse ponto deveriam os bens coletivos ser tutelados apenas quando as condutas contra eles dirigidas tivessem alguma magnitude de modo que, em última análise, seriam reconduzíveis as lesões aos bens individuais. ${ }^{622}$

O que fundamenta a tese acima aludida não é apenas o critério da racionalidade ética, mas um temor de que as técnicas de tutela propriamente penais estendam sua aplicação às infrações que não pertencem ao mencionado núcleo, de forma a tomar duas direções. A primeira delas é a de que apenas as sanções mais aflitivas, como as penas privativas de liberdade, deveriam ser destinadas às condutas atentatórias aos pressupostos fundamentais de convívio social e, justamente a gravidade dessas penas é que justifica o

\footnotetext{
${ }^{619}$ RANDO CASERMEIRO, Pablo. op. cit., p. 220.

${ }^{620}$ ZUÑIGA RODRÍGUEZ, Laura. Bases para un modelo de imputación de responsabilidad penal a las personas jurídicas, cit., p. 28-31 e p. 91-92.

${ }^{621}$ Veja-se, por exemplo, HASSEMER; Winfried. Persona, mundo y responsabilidad: bases para una teoria de la imputación en derecho penal. Traducción de Francisco Muñoz Conde y Maria del Mar Díaz Pita. Valencia: Tirant lo Blanch, 1999. p. 54-56.

${ }^{622}$ Id. Ibid., p. 68.
} 
arsenal de garantias disponíveis no âmbito do processo penal. A outra se refere a uma intranquilidade da doutrina: de um lado entende-se que a tutela penal de assuntos que poderiam ser relegados à esfera administrativa levaria a uma bagatelização do ramo criminal, o que auxiliaria a perda da perspectiva de valores sociais pelos cidadãos. ${ }^{623}$ É o que já fora exposto acima, isto é, a possível prática de condutas que os cidadãos viessem a entender lícitas porque equivocadamente assumiram que houve mudanças nas concepções socioculturais básicas. Por outro lado, o surgimento de ilícitos de massas, de grandes cifras, provoca fundamental mudança quanto à atribuição de responsabilidade, ficando em evidência a solidária e a objetiva. ${ }^{624} \mathrm{E}$ isso pode ser ampliado até alcançar as figuras correspondentes ao núcleo duro do direito penal, sendo certo que isso faz com que haja um desejo de excluir todos os ilícitos que não possam ser tachados de integrantes do núcleo duro penal. ${ }^{625}$ É por tais razões que se verificam as propostas de Hassemer quanto a um direito de intervenção e, ainda, a de Silva Sánchez, quanto a um direito penal de velocidades. ${ }^{626}$

Crê-se, por ora, que basta a menção da necessidade do núcleo duro penal ser submetido a uma racionalidade ética até mesmo porque estas exigências éticas podem perfeitamente ser contrapostas a outros níveis de racionalidade, em especial a teleológica e a pragmática, sendo o caso de buscar o que Díez Ripollés chamou de eficiência. ${ }^{627}$

\subsection{A racionalidade teleológica}

As ponderações quanto ao bem jurídico tutelado no nível teleológico oferecem uma dimensão diferente daquela apresentada no nível ético. Já não se trata de fixar elementos de indubitável proteção penal, mas de estipular quais os objetivos do ramo penal e quais deveriam ser os do poderio sancionador da Administração. Quanto a isso, ainda que haja

\footnotetext{
${ }^{623}$ HASSEMER; Winfried. Persona, mundo y responsabilidad: bases para una teoria de la imputación en derecho penal, cit., p. 56. Vide, também, DÍEZ RIPOLLÉS, José Luís. El derecho penal simbólico y los efectos de las penas, cit., p. 11.

${ }^{624}$ RANDO CASERMEIRO, Pablo. op. cit., p. 225.

${ }^{625}$ HASSEMER; Winfried. Persona, mundo y responsabilidad: bases para una teoria de la imputación en derecho penal, cit., p. 55-57.

${ }^{626}$ Id. Ibid., p. 67-72. Vide, ainda, SILVA SÁNCHEZ, Jesús-María. La expansión del derecho penal, cit., 2001, p. 153-154.

${ }^{627}$ DÍEZ RIPOLLÉS, José Luís. Política criminal y derecho penal: estúdios, cit., p. 96 . O autor entende que o direito punitivo só será eficiente caso mescle os variados âmbitos de racionalidade, ainda que alguns sejam mitigados em favor de outros.
} 
discussões a respeito, há alguns pontos que podem ser tidos como comuns. ${ }^{628}$ Veja-se: a) o direito penal e o administrativo sancionador protegem os mesmos bens jurídicos; b) o direito administrativo sancionador se satisfaz mediante uma prévia proteção, sendo uma espécie de antecipação da proteção penal; c) os principais elementos a integrar o direito administrativo sancionador são as estruturas de perigo; d) o direito penal deve ter por objeto as condutas que atacam e que põem em iminente perigo os bens jurídicos, ao passo que o direito administrativo sancionador se configura desde condutas de perigo abstrato, concreto ou mesmo hipotético; e) há situações em que a proposta de distinção entre as ilicitudes se funda na gravidade das condutas praticadas, de modo que o uso dos tipos de perigo funciona como verdadeira concreção da fragmentariedade, como é feito tradicionalmente pela doutrina. ${ }^{629}$

Inobstante a existência dos pontos comuns, podem-se verificar alguns problemas aqui. Por exemplo, não há maturidade administrativo-penal para que os tipos de perigo possam distribuir o conteúdo social administrativo-penal e, por isso há necessidade de abandonar o exclusivo critério do risco para que se proceda à distinção adequada, afastando-se da redução de complexidade da discussão por destacar simplesmente tipos de perigo e de resultado. ${ }^{630}$

Definitivamente não se mostra razoável pensar que o problema da confusão, de mescla e da distinção entre o direito penal e o administrativo sancionador resuma-se na apreciação das figuras de perigo abstrato ou hipotético sob a óptica do direito administrativo sancionador; tampouco que as necessidades de intervenção do controle punitivo demandem a utilização de certos tipos penais.

Também se deve considerar que os enfoques acima apontados propiciam a existência de elementos de reflexão para a escolha de técnica legislativa para tipificação de delitos - especialmente os tipos de perigo - algo mais voltado à racionalidade lógicoformal que propriamente à teleológica. ${ }^{631}$

Ademais, é bom ter em conta que distinguir os âmbitos de ilicitude penal e administrativa sancionadora resumidamente em termos de perigo e dano não acrescenta muito de eficácia para solucionar a questão. De fato, a insistência na separação dos ramos

\footnotetext{
${ }^{628}$ RANDO CASERMEIRO, Pablo. op. cit., p. 282.

${ }^{629}$ Id., loc. cit.

${ }^{630}$ REBOLLO PUIG, Manuel. op. cit., p. 572-576; vide, ademais, SUAY HERNÁNDEZ, Celia. Los delitos contra la salubridad y seguridad del consumo en el marco de las relaciones entre derecho penal y el derecho administrativo sancionador. Cuadernos e Derecho Judicial, n. 11, p. 149, 1997.

${ }^{631}$ RANDO CASERMEIRO, Pablo. op. cit., p. 284.
} 
acima aludidos pelo critério dano-perigo não só deixa de apresentar resultados eficazes e satisfatórios como auxilia que os torne ainda menos claros quanto aos seus âmbitos de atuação. ${ }^{632}$

Assim, não se pode desperdiçar a oportunidade de aproveitar a tradicional distinção para que se tenham ideias para o melhor deslinde legislativo quanto à formação dos ilícitos penais e administrativos. Significa dizer que reconhecer que o foco do direito administrativo sancionador deva ser o de um papel de antecipação penal levando-se ao poderio sancionador da Administração que se atenha a condutas de exposição a perigo. ${ }^{63}$ Quanto mais se afastasse do núcleo penal, mais braços do direito administrativo sancionador estariam a entornar as condutas ilícitas. Não se pode negar, igualmente, a importância de trabalhos que se põem a distinguir situações de perigo concreto, abstrato e hipotético, tendo-se em vista sua utilidade para delinear o objeto de proteção de cada infração a eles relacionada. Todavia, admite-se que a existência dos tipos de perigo como conhecidos hoje igualmente se presta a confundir ainda mais os âmbitos de atuação penal e administrativa, auxiliando-se na perda de referência ético-penal, envolvendo, pois, relação com o (des)conhecimento da ilicitude.

O manejo de figuras típicas com conceitos diferentes de perigo, como critério teleológico, deve se prestar a ajudar nas decisões quanto às tipificações abertas. Em outras palavras, não se fala propriamente numa orientação legislativa de que a estrutura de perigo demande tipos de perigo, mas na preocupação para solucionar problemas de racionalidade lógico-formal e linguística, porque se questionam, mormente, as figuras típicas abertas e as questões intrinsecamente relacionadas à segurança jurídica. ${ }^{634}$ Daí a vantagem da análise sob diferentes formas de racionalidade, tendo-se a possibilidade de entender mais claramente o que se deseja proteger e com quais instrumentos, o que se enquadra dentro do parâmetro de racionalidade teleológica.

Desta forma, quando se criticam os modelos de perigo e sua amplitude, de fato se está a pontuar a racionalidade jurídico-formal e linguística, especialmente quanto à imprecisão dos tipos e sua intrínseca insegurança jurídica.

\footnotetext{
${ }^{632}$ RANDO CASERMEIRO, Pablo. op. cit., p. 285.

${ }^{633}$ Id. Ibid., p. 286.

${ }^{634}$ AGUADO CORREA, Teresa. El principio de proporcionalidad en derecho penal, cit., p. 325.
} 
Em suma, o papel desenvolvido pelas estruturas de perigo deve-se circunscrever a dar concretude ao objeto de proteção de cada ramo do ordenamento jurídico, não a determinar formas de redação típica.

\subsubsection{Breves, porém necessárias, reflexões sociológicas}

Não há como fugir das questões relativas à sociedade de risco quando se pretende discorrer sobre os crimes de perigo. É essa perspectiva que permitiu inserir-se um novo viés de bem jurídico na seara penal, sendo responsável por situações de muita controvérsia doutrinária.

Verificam-se na doutrina, pelo menos desde a década de oitenta, muitas ponderações sociológicas nos mais variados âmbitos de discussão, como o dogmático, o criminológico e o político-criminal, a ponto de defender-se que o domínio dos fundamentos dos grandes temas de direito penal só pudesse ser alcançado por aproximações sociológicas feitas junto ao Direito. ${ }^{635}$ Uma das provas de que isso é verdadeiro é a constante referência à sociedade de risco, e o motivo de mencioná-la aqui é implicação na tomada de postura sobre o conteúdo que deveria ter o direito penal e o administrativo sancionador, não sendo raras as abordagens que mencionam a sociedade de risco como uma indevida expansão do direito penal.

Igualmente certo é que já se constatou que o atual momento histórico é composto por uma evolução tecnológica sem igual, fazendo surgir as sociedades pós-industriais, cujas benesses são as inegáveis melhoras na qualidade de vida e cujos aspectos negativos são as percepções e surgimentos de novos riscos, os quais representam custos sociais globais do sistema. ${ }^{636} \mathrm{~A}$ inexistência de uma gestão adequada destes custos fez com que se recorresse ao uso do direito penal para a proteção contra condutas possivelmente geradas pela vivência numa sociedade de risco. Isso é o que suscitou a geração de concepções no sentido de haver uma intromissão expansiva do direito penal em setores cuja gestão

\footnotetext{
${ }^{635}$ LAURENZO COPELLO, Patricia. El enfoque teleológico-funcional en el sistema del delito. Breves notas sobre su alcance garantístico. In: QUINTERO OLIVARES, Gonzalo; MORALES PRATS, Fermín. El nuevo derecho penal econômico: estudios penales en Memoria del professor José Manuel Valle Muñiz. Pamplona: Aranzadi, 2001. p. 437.

${ }^{636}$ Para estudo específico dos ilícitos e seu envolvimento com a tecnologia, vide CRESPO, Marcelo Xavier de Freitas. Crimes digitais, cit.
} 
poderia ser conduzida por outros ramos do direito. ${ }^{637}$ Também se fala que o foco equivocado do direito penal da sociedade de risco encontra-se na equivocada mira do fenômeno com perspectivas de controle, não de gestão. Há doutrina no sentido de que na sociedade de risco dever-se-ia preocupar com a gestão do risco, numa tentativa de diminuílo, não com seu controle. ${ }^{638}$

A transformação do direito penal num ramo que passou a proteger bens jurídicos difusos pela utilização de tipos de perigo abstrato fez surgir, no entanto, vozes contrárias a tal aplicação, sendo reconhecida a Escola de Frankfurt neste particular. Sua proposta, capitaneada por Schünemann, defende uma reconstrução do que se entende por bem jurídico para limitar-lhe ao que tenha como referência próxima o indivíduo, numa maior proximidade com os delitos de resultado. ${ }^{639}$

$\mathrm{O}$ enfoque da sociedade de risco ganha destaque na medida em que neste trabalho se verificam claros registros de que o direito penal desta sociedade representa uma administrativização na sua estrutura, funcionando o ramo penal como o administrativo. Isto é rechaçado por parte da doutrina, que tem concepções mais próximas a um direito penal clássico; ao mesmo tempo é percebido por Silva Sánchez como de impossível regresso a velhas concepções de bem jurídico. ${ }^{640}$ Aliás, sua obra tem próxima relação com o critério teleológico na apreciação do direito penal e dos riscos, havendo, portanto, relação dos fins do direito penal e do direito administrativo sancionador.

Nesta perspectiva é que o direito administrativo sancionador proíbe desde uma apreciação global de reforço da gestão administrativa. Por tal razão, para que se considere um ato como ilícito administrativo não se exige que haja lesão a bem jurídico, mas que a prática reiterada por um número maior de indivíduos possa gerar o risco pela proliferação

\footnotetext{
${ }^{637}$ Sobre a temática, veja-se SILVA SÁNCHEZ, Jesús-María. La expansión del derecho penal, cit., 2001, p. 26 e ss. Vide, ainda, capítulo específico neste trabalho.

${ }^{638}$ NIETO GARCÍA, Alejandro. Derecho administrativo sancionador, cit., p. 33-34.

${ }^{639}$ Quanto a perspectivas da Escola de Frankfurt diante da sociedade de risco, veja-se: DÍEZ RIPOLLÉS, José Luís. De la sociedad del riesgo a la seguridad ciudadana: un debate desenfocado. Revista Electrónica de Ciencia Penal e Criminología, Granada, n. 7, p. 3-6, 2005. Disponível em: $<$ http://bdjur.stj.jus.br/xmlui/bitstream/handle/2011/40519/sociedad_riesgo_seguridad_ripolles.pdf?sequence= 1>; ademais, GRACIA MARTÍN, Luis. Prolegómenos para la lucha por la modernización y expansión del derecho penal y para la crítica del discurso de resistencia, cit., p. 60 e ss.; Vide, ainda, BLANCO LOZANO, Carlos. Tratado de política criminal: la política criminal aplicada. Barcelona: Bosch, 2007. t. 2, p. 100.

${ }^{640}$ Que na obra La expansión del derecho penal, cit., 2001, p. 149 e ss. menciona a impossibilidade de regresso ao "bom e velho direito penal liberal", defendendo que o direito penal tenha uma posição quase que intermediária entre o clássico e o direito administrativo sancionador.
} 
de condutas similares. ${ }^{641}$ De outra forma, busca o direito penal a imputação a alguém de uma conduta que, de per si, é suficientemente perigosa para a manutenção íntegra do bem jurídico. ${ }^{642}$

Se se observa a diferente perspectiva desde a que um e outro ramo do direito formulam proibições em atenção às suas finalidades, poderá comprovar-se como o risco para bens jurídicos pode ser objeto unicamente de proteção pelo direito penal enquanto os demais, não voltados aos bens jurídicos, mas para a efetividade de um determinado setor de atuação da Administração, ficará adstrito ao direito sancionador. ${ }^{643}$

Pode-se dizer, então, que esta concepção tem seu nascedouro na teoria dos delitos cumulativos ventilada por Kühlen, não aceita por Silva Sánchez porquanto questione o quanto condutas individuais possam afetar um bem jurídico transindividual. ${ }^{644}$

A tese de Silva Sánchez, então, instrumentaliza o modelo teleológico de limitação entre as ilicitudes penal e administrativa não porque o ilícito administrativo careça de potencialidade para criar riscos juridicamente relevantes, mas que não se pode seguir tendo em conta os bens jurídico-penais como referências inexoráveis de toda atividade proibitiva e repressiva do Estado. ${ }^{645}$ Então, as condutas que não se destinassem à imediata lesão ou exposição a perigo dos bens jurídicos deveriam ser submetidas à apreciação de um modelo setorial de gestão de modo que os questionamentos sobre a necessidade/possibilidade do direito penal atuar perante tais ocorrências seriam respondidos com a apresentação da teoria da imputação objetiva, que torna inviável o uso do direito penal com esta finalidade. ${ }^{646}$ Resumindo, o direito administrativo sancionador ficaria encarregado das apreciações dos problemas envolvendo grandes cifras, restando ao direito penal a imputação de responsabilidade a alguém que, com sua conduta, exponha a risco bens jurídico-penais.

Partindo-se das premissas de Silva Sánchez pode-se concluir, então, que muitos dos delitos de perigo abstrato deveriam ser remetidos ao direito administrativo sancionador,

\footnotetext{
${ }^{641}$ NIETO GARCÍA, Alejandro. Derecho administrativo sancionador, cit., p. 92; Vide, ademais, DEBBASCH, Charles. Ciencia administrativa. Administración pública. 2. ed. rev. y aumen. Traducida por José Antônio Colás Leblanc. Madrid: Instituto Nacional de Administración pública, 1981. p. 25.

${ }^{642}$ SILVA SÁNCHEZ, Jesús-María. La expansión del derecho penal, cit., 2001, p. 125 e ss. numa ponderação próxima a este autor, vide, também CARNEVALI RODRIGUEZ, Raúl. Derecho penal y derecho sancionador de la Unión Europea. Granada: Comares, 2001. p. 163.

${ }^{643}$ RANDO CASERMEIRO, Pablo. op. cit., p. 293.

${ }^{644}$ SILVA SÁNCHEZ, Jesús-María. Política criminal moderna? Consideraciones a partir de los ejemplos urbanísticos en el nuevo Codigo Penal Español. Actualidad Penal, n. 23, p. 127, 1998.

${ }^{645}$ Id. Ibid.

${ }^{646}$ Id. Ibid., p. 445-446.
} 
somente sendo possível intervir penalmente em casos excepcionais. ${ }^{647}$ Mas, quanto a isso, cabe ressaltar que não deve ser visto como verdade inquestionável a atuação do direito penal quando as condutas voltarem-se a bens jurídicos individuais e o direito administrativo sancionador aos bens transindividuais, numa perspectiva idealizadora. Aliás, tal ponto de vista mostra-se, em verdade, questão tida pela doutrina como de menor importância, sendo até mesmo considerada uma evasiva quanto à tentativa de diferenciação. ${ }^{648}$

Quanto aos papéis de gestão e proteção, em tese atribuídos ao direito administrativo sancionador e ao direito penal, há que se frisar que as expressões em questão - gestão e proteção - podem soar equívocas, não sendo apropriado delas se valer para a distinção, uma vez que se poderia, ainda que de forma ampla, admitir que o direito penal gerencia bens jurídicos. ${ }^{649}$ Afinal, argumentos puramente quantitativos levariam a crer que o direito administrativo sancionador deveria atuar pura e simplesmente em situações em que parte da população atuasse contra os bens nucleares, como a vida, o que não se mostra correto, considerando-se unicamente tal assertiva. ${ }^{650}$

Mas, em nível teleológico também se deve atentar para a questão da finalidade das penas. Igualmente se deve lembrar que as distinções que se consubstanciam em critérios como o do bem jurídico protegido e as condutas que devem integrar cada ordenamento não obtiveram os resultados mais frutíferos possíveis. Então, passando a analisar a questão desde o ponto de vista do conteúdo da infração até a consequência jurídica, ter-se-ia em destaque a coerente fixação dos objetivos das punições, gerando efeitos reflexos quanto a uma necessária percepção dos conteúdos tutelados.

Em linhas rápidas, pode-se pontuar, então, que relativamente às prevenções geral e especial negativas, ambas podem perfeitamente ter efeitos intimidatórios, ainda que a ameaça penal soe mais vultosa. Eis, então, aspectos da racionalidade pragmática, portanto alvo de comentários em momento oportuno, mais abaixo.

\footnotetext{
${ }^{647}$ SILVA SÁNCHEZ, Jesús-María. Política criminal moderna? Consideraciones a partir de los ejemplos urbanísticos en el nuevo Codigo Penal Español, cit., p. 447.

${ }^{648}$ GARCIA ALBERO, Ramón. La relación entre ilícito penal e ilícito administrativo: texto y contexto de las teorías sobre la distinción de ilícitos, cit., p. 333-334.

${ }^{649}$ RANDO CASERMEIRO, Pablo. La distinción entre el derecho penal y el derecho administrativo sancionador, cit., p. 299.

${ }^{650}$ Id., loc. cit. $\mathrm{O}$ autor questiona: "e se uma parte importante da população atentasse indiscriminadamente contra a vida dos demais?".
} 
Já no que tange à prevenção geral positiva, a despeito de haver importantes diferenças entre o direito penal e o administrativo sancionador, não se nega que este possa ter um fim de ressocialização/reinserção social, embora seja esta função penal que mais distancia este ramo dos demais. Por isso mesmo Silva Sánchez já afirmou que seria importante que as penas fossem impostas por uma instância judicial penal, possibilitando o quanto possível os elementos de estigmatização social e a capacidade simbólicocomunicativa do direito penal. ${ }^{651}$ Parte-se, então, do pressuposto de que a atuação do direito penal é um assunto sério, diferenciando-se de "simples" infração administrativa. Então cabe considerar que é um importante critério de distinção a diferente intensidade da prevenção geral positiva nos distintos ramos jurídicos. Desta forma, o reconhecimento de importante déficit de integração da norma pelos cidadãos pode ser um dado determinante na decisão de optar pelo direito penal ou deixar de fazê-lo, despenalizando a conduta. ${ }^{652}$ Também por isso Silva Sánchez asseverou que a finalidade integradora das penas passa normalmente pela reafirmação simbólica da norma como diretriz válida, correta e a correspondente estigmatização do infrator como alguém que se distancia do grupo daqueles que creem nas normas. ${ }^{653}$

O fato é que o direito administrativo atua ante violações rotineiras, de modo que as punições a elas impostas destinam-se a reforçar o cumprimento de leis administrativas, não tendo, em regra, aptidão para ensejar a adesão dos cidadãos e determinados valores. ${ }^{654}$ Mas isso não está correto na medida em que o Estado não deve se limitar a condicionar o cidadão ao mero cumprimento das normas senão pelo conhecimento material das mesmas, de modo que seja possível esclarecer à população o sentido das proibições, integrando-as aos valores refletidos. Então, se há o desejo de que o cidadão vá além da obediência cega, obediência ao direito, é preciso reconhecer que o direito administrativo auxilia, ainda que timidamente, a função preventiva. Assim, se reconhece que a função preventiva do direito administrativo terá melhor aproveitamento se houver a alteração na política sancionadora. Da forma como se encontram vinculados e mesclados o direito penal e o administrativo,

\footnotetext{
${ }^{651}$ SILVA SÁNCHEZ, Jesús-María. La expansión del derecho penal, cit., 2001, p. 125 e ss. numa ponderação próxima a este autor, vide, também CARNEVALI RODRIGUEZ, Raúl. op. cit., p. 162.

${ }^{652}$ RANDO CASERMEIRO, Pablo. op. cit., p. 357.

${ }^{653}$ SILVA SÁNCHEZ, Jesús-Maria. Aproximación al derecho penal contemporáneo, cit., p. 233. Vide, ainda, CID MOLINÉ, José. Garantías y sanciones (argumentos contra la tesis de la identidad de garantías entre las sanciones punitivas), cit., p. 143.

${ }^{654}$ FORCE, Robert. Administrative adjudications of traffic violations confronts the doctrine of separation of powers. Tulane Law Review, n. 49, p. 133, 1975.
} 
não se consegue propiciar ao cidadão que os distinga, perdendo-se parte da possível e desejável eficácia.

Quanto à prevenção especial positiva, entende-se também ser uma finalidade possível de ser buscada pelo direito administrativo sancionador, o que certamente deixa-o ainda mais próximo do ramo penal. Cita-se que tal finalidade apenas soa estranha ao ramo administrativo por não ser comumente utilizada e que não há razão para descartá-la. ${ }^{65}$ Fato é que a reinserção é notoriamente buscada pelo direito penal, especialmente pela utilização da pena privativa de liberdade, o que não impede sua perseguição pelo ramo não penal.

Quanto às finalidades da pena, parece correta a afirmação de que o direito administrativo sancionador pode ocupar-se legitimamente de todos os fins preventivogerais e especiais próprios do direito penal. Nesse particular, a prevenção geral positiva é algo importante a ser observado pelo direito administrativo sancionador, não havendo razões para que não o seja, embora o mesmo já não possa ser dito da prevenção especial positiva, até agora reduto do direito penal. ${ }^{656}$ Aliás, quanto a esta função, muito haveria de se discutir aí porquanto normalmente seria de se admitir uma possível reinserção social apenas limitada pelo direito administrativo sancionador até mesmo porque a função está intimamente relacionada com a pena de prisão, típica da instância penal. ${ }^{657}$

No que se refere às prevenções geral e especial negativas, igualmente cabe o entendimento de poderem ser perseguidas pelo direito administrativo sancionador. Vê-se, pois, que há muitas semelhanças entre ele e o ramo penal, possibilitando e reforçando a tese de que, em face da sociedade de risco, misturam-se de forma perigosa a confundir cidadãos sobre seus limites de atuação, isto é, em qual momento violam normas penais e em qual violam outras proibições. Se há tantas semelhanças entre o direito penal e o administrativo sancionador, o que dizer do direito penal mais recente, voltado a cumprir normas administrativas?

Como comentários iniciais dirigindo-se a uma conclusão quanto ao aspecto teleológico, inclusive quanto à sua eficiência, pode-se afirmar que os critérios abaixo relacionados são os que podem auxiliar na distinção entre as ilicitudes penal e administrativa, com vistas ao melhor conhecimento do que se reputa criminalmente ilícito:

\footnotetext{
${ }^{655}$ RANDO CASERMEIRO, Pablo. op. cit., p. 362.

${ }^{656}$ Id. Ibid., p. 364.

${ }^{657}$ Id., loc. cit.
} 
a) Os fins da Administração são essenciais para o condicionamento do conteúdo de proteção do direito administrativo sancionador. Com base nessa apreciação será possível delimitar seu campo de atuação, retirando do seu âmbito de aplicação aquelas condutas que também não serão alvo do ramo penal; ${ }^{658}$

b) O direito administrativo sancionador pode se prestar a ser uma instância prévia à penal. Eis aqui um possível parâmetro de aplicação da política criminal para situações que envolvam as estruturas de perigo numa verdadeira análise primária;

c) Os sistemas de responsabilidade penal e administrativa são distintos, de modo que o dolo e a culpa não precisam ser exaustivamente trabalhados no âmbito administrativo (devido aos fins da Administração);

d) Apesar de o direito administrativo sancionador perseguir parcial e concomitantemente fins ínsitos ao ramo penal, não se trata de ramo capaz de atuar eficazmente quanto a todos eles. Em outras palavras, significa dizer que o direito administrativo parece não ser capaz de promover a ressocialização, além de que suas sanções não têm a mesma força estabilizadora notada no ramo penal.

Essas quatro considerações acima mencionadas se prestam, então, a que se possa perseguir estratégias destinadas a identificar os tipos de condutas que devem ser objeto de cada ramo, seja ele penal, seja ele administrativo sancionador.

Também a título de conclusão, do contrário, a premissa de que o direito penal deve proteger bens jurídicos individuais, cabendo ao administrativo a proteção dos transindividuais não parece esclarecedora. $\mathrm{O}$ mesmo pode-se dizer da máxima de que o direito penal estrutura seu sistema baseado em responsabilidade subjetiva e o administrativo apenas e tão somente na objetiva. Além disso, não soa convincente a afirmativa de que o direito penal e o administrativo sancionador se distinguem por assumirem diferentes perspectivas de atuação: proteção e gestão, respectivamente. ${ }^{659}$

Uma última questão a ser objeto de reflexão reside no fato de que possa haver incompatibilidade entre o critério teleológico em face da ética. Então, considerando-se

\footnotetext{
${ }^{658}$ RANDO CASERMEIRO, Pablo. op. cit., p. 366. O autor apresenta o exemplo das violações à honra, que não seriam objeto do direito administrativo sancionador, mas que, caso fossem excluídas da proteção penal, caberiam como objeto do direito civil para sua tutela.

${ }^{659}$ Nesse sentido, Id. Ibid., p. 366-367, que igualmente menciona as demais assertivas como pouco convincentes.
} 
caber ao direito penal a atuação em face das condutas de lesão e, ainda, ao direito administrativo sancionador os perigos de lesão, seria admissível que condutas violadoras de bem jurídico de forma direta viessem a ser objeto do direito administrativo sancionador. ${ }^{660} \mathrm{E}$ há doutrina nesse sentido que exemplifica com o caso de crimes tributários e meio ambiente, esclarecendo que, então, deve ceder o aspecto teleológico em face do ético. ${ }^{661}$

Eis as ponderações devidas em nível teleológico. Segue-se, agora, para a racionalidade pragmática.

\subsection{Breves palavras sobre a racionalidade pragmática}

Pensando-se no funcionamento eficaz dos sistemas punitivos, é no âmbito da racionalidade pragmática que se pode encontrar a missão dos objetivos traçados pela racionalidade teleológica em relação às possibilidades reais de intervenção social passíveis de serem tratados no âmbito legislativo. ${ }^{662}$ Tal situação é que permite entender que o aspecto pragmático, ainda que reflexamente, pode propiciar algum auxílio na distinção das ilicitudes e no atingimento do seu conhecimento.

Tendo-se em consideração uma disposição punitiva qualquer, seja ela penal ou administrativo-sancionadora, seu grau de ajuste à realidade pode ser mensurado em duas medidas: o da eficácia e o da eficiência. Uma lei será eficiente quando cumprir seu papel e será eficaz se, com seu cumprimento, obtiver os resultados pretendidos. ${ }^{663}$

Quanto à eficiência, valora-se que a proibição seja suscetível de cumprimento e que se terá condição de reagir com a aplicação da lei em face do descumprimento das normas. Por outro lado, no âmbito da eficácia analisar-se-á que o cumprimento da norma produza os efeitos esperados, que a aplicação contrafática da norma produzirá os mesmos efeitos da tutela e que a aplicação da norma seja mantida num âmbito de responsabilidade e sanção.

A apreciação realizada nos âmbitos da eficácia e eficiência, portanto, poderá proporcionar argumentos para a diferenciação entre as ilicitudes penal e administrativa

\footnotetext{
${ }^{660}$ RANDO CASERMEIRO, Pablo. op. cit., p. 368-369. O autor ressalta que, no caso tributário, há necessidade da importância ser vultosa.

${ }^{661}$ Id. Ibid.

${ }^{662}$ DÍEZ RIPOLLÉS, José Luís. La racionalidad de las leyes penales: practica y teoria, cit., p. 95.

${ }^{663}$ RANDO CASERMEIRO, Pablo. op. cit., p. 368-369.
} 
pelo que seria possível apreciar se o sistema punitivo estudado funciona razoavelmente ou não e, em caso negativo, procurar a correção para tal situação. Este seria o objetivo da racionalidade pragmática desde uma perspectiva dos sistemas punitivos.

Sob essa perspectiva caberia analisar, por exemplo, aspectos como o da agilidade e eficácia dos ramos penal e administrativo sancionador e questões relativas ao custobenefício em adotar-se um ou outro ramo. Não há, contudo, demonstrações de que o processo administrativo sancionador seja mais ágil e eficaz que o direito e o processo penal, embora empiricamente seja admissível que se presuma ter o procedimento administrativo mais rapidez que o judicial. Quanto a isso, seria preciso um imenso e trabalhoso estudo especialmente dirigido a esta constatação, o que foge do escopo deste trabalho.

Também seria o caso de analisar os efeitos preventivo-gerais,supostamente produzidos de forma mais acentuada pelo direito penal que pela instância administrativosancionadora. Todavia, tal constatação, mais prática que teórica, não representa necessariamente um instrumento que se preste efetivamente a auxiliar na distinção das ilicitudes e a obtenção do seu conhecimento, além de que sua constatação, como dito, por sua extensão e complexidade, igualmente deveria ser alvo de pesquisa autônoma.

Em suma e finalizando, a apreciação pragmática deveria se ater às variáveis de eficácia e eficiência dos ramos administrativo sancionador e do penal para que se pudesse observar nitidamente a distribuição do controle punitivo sem que se baseasse em presunções. Isto auxiliaria especialmente nos casos em que as racionalidades ética e teleológica não estivessem em condições de promover a diferenciação das ilicitudes. Todavia, isso somente se obteria mediante pesquisa que foge ao escopo deste trabalho.

\subsection{A racionalidade jurídico-formal}

Vistos os critérios de racionalidade até aqui expostos, seria possível concluir, ou pelo menos ter em conta aspectos mais significativos da distinção entre as ilicitudes penal e administrativa, incluindo-se aí a atuação de cada ramo respectivo.

Os demais critérios de racionalidade - o jurídico-formal e o linguístico - não representam, pois, níveis adequados para as distinções, tendo um papel menos vigoroso 
quanto a esse aspecto. Isto porque as leis deveriam supostamente atender a ambos, em ambos os casos. Vejam-se, então, alguns problemas pontuais.

O sistema punitivo pátrio está fundado em uma irracionalidade jurídico-formal generalizada. Não há, no Brasil, critérios claros de distinção das atuações penais e administrativas, o que provoca, além das óbvias disfuncionalidades sistêmicas, confusões, equívocos e situações de erro quanto à ilicitude.

Há formas ambíguas com que são construídos os discursos e representações sociais que resultaram na legislação penal brasileira nas últimas duas décadas. De fato, há dualidade discursiva advinda de lógicas conflitantes, produzindo um sistema penal inusitado com vistas a acomodar estas lógicas, que funcionam com distintos princípios de justiça e ordem pública, "produzindo diferentes "justiças" e punições para situações e indivíduos desiguais. São lógicas conflitantes, cada uma delas pautada numa determinada visão de mundo, ora universalista, ora excludente, ora igualitária, ora hierárquica, ora retributiva, ora preventiva, e que se chocam no momento de resoluções legislativas.",664

Nessa perspectiva, os mesmos legisladores que defendem uma justiça mais equânime são capazes de votar e propor projetos de lei extremamente rigorosos e seletivos em seu alcance. Essa dualidade discursiva é reveladora de dois modos distintos de pensar o Brasil e sua cultura jurídica. Modos que são caracterizados por lógicas conflitantes, mas que também se complementam, produzindo uma esquizofrenia legislativa ou um hibridismo jurídico, que atente aos diferentes interesses e modelos. ${ }^{665} \mathrm{~A}$ irracionalidade retromencionada talvez possa ser explicada não só pela falta de política criminal clara advinda do legislador, mas também pelo fato de que há grande facilidade em se aprovar leis penais e também de gerar conteúdos administrativos reprováveis.

Desta forma, sendo a premissa primária a necessidade de que o sistema de controle social parta da criação de expectativas de conduta e de que ela se obtém com as consequências de um dado comportamento, então a falta de alinhamento entre as instâncias penal e administrativa perturba a ordem social em seu conjunto, quebrando-se o efeito de

\footnotetext{
${ }^{664}$ MENDONÇA, Nalayne. Penas e alternativas: um estudo sociológico dos processos de agravamento das penas e de despenalização no sistema de criminalização brasileiro (1984-2004). 1998. Tese (Doutorado) Programa de Pós-Graduação em Sociologia e Antropologia da UFRJ, Rio de Janeiro, 1998.

${ }^{665}$ Id. Ibid.
} 
prevenção geral atribuído normalmente ao sistema de controle social. ${ }^{666} \mathrm{E}$ isso é reforçado pelo incoerente uso das estruturas de perigo e resultado pelo legislador.

Assim, apesar de se dizer que ainda não há muitas pesquisas nacionais que possam demonstrar por números o tamanho da irracionalidade jurídico-formal brasileira, há estudos que permitem algumas ponderações.

Inclusive, há obra na qual se menciona o movimento de expansão do direito penal quanto à criminalização de condutas, como as relacionadas ao racismo, à lavagem de dinheiro e ocultação de bens, aos delitos ambientais e contra o consumidor e contra a ordem econômica, tributária e as de relação de consumo. ${ }^{667} \mathrm{O}$ mesmo autor aponta sinais do direito penal de emergência, especialmente indicando-se a lei de crimes hediondos e de combate ao crime organizado. Tudo isso aponta numa política de law and order. ${ }^{668}$

Também há estudo refletindo quanto a tal irracionalidade, aponta a introdução de medidas despenalizadoras surgidas na década de 80 , além da criação dos delitos de menor potencial ofensivo, da lei dos juizados especiais criminais e da lei de execução penal, sem esquecer as menções quanto à lei dos crimes hediondos, de combate ao crime organizado e, ainda, da lei que instituiu o Regime Disciplinar Diferenciado. ${ }^{669}$

A conclusão a que se pode chegar, como já foi dito anteriormente, é que as estruturas de perigo e de resultado não são aptas a traçar as diferenças entre o que deve compor a ilicitude penal e a administrativa, já que todas as condutas podem se ver subsumidas a essas estruturas, com vistas a resguardar os mesmos bens jurídicos.

Tudo isso resulta num solapamento dos ilícitos penais e administrativos, levando-se a crer que o legislador deixou de ponderar a proteção de bens de forma global, havendo coincidência de tipos penais e administrativos.

Todavia, os exemplos e estudos acima mencionados certamente não esgotam as demonstrações de falta de técnica legislativa coordenada e coerente para a criação de tipos penais e limitação quanto à ilicitude penal. Desde o plano positivo parece que somente

\footnotetext{
${ }^{666}$ ATIENZA RODRIGUEZ, Manuel. Contribución a una teoría de la legislación, cit., p. 32. Nas palavras do autor, a finalidade da atividade legislativa deve ser a sistematização das leis, que não devendo existir lacunas, contradições nem redundâncias, o que torna o direito um mecanismo de prevenção das condutas humanas e suas consequências, num sistema se segurança jurídica.

${ }^{667}$ AZEVEDO, Rodrigo Ghiringhelli de. Tendências do controle penal na modernidade periférica: as reformas penais no Brasil e na Argentina na última década. 2003. Tese (Doutorado em Sociologia) Instituto de Filosofia e Ciências Humanas, Universidade Federal do Rio Grande do Sul, Porto Alegre, 2003. ${ }^{668}$ Id. Ibid.

${ }^{669}$ MENDONÇA, Nalayne. op. cit.
} 
uma reforma penal promovida com base no conjunto do sistema punitivo é que poderia minorar tais efeitos negativos desta situação. E isso representa também fazer o uso cuidadoso e criterioso das estruturas de perigo, cabendo ainda a ponderação de que se utilizem magnitudes pré-determinadas para auxiliar na distinção. ${ }^{670}$

\subsection{Algumas palavras a título de encerramento}

Nas palavras de Atienza Rodríguez, a eficiência é algo como uma dimensão transversal, sendo menos que um nível independente de racionalidade, mas uma verdadeira qualidade exigível a cada nível de racionalidade e de inter-relação entre elas. ${ }^{671}$ É também uma análise do quanto se pode realmente aproveitar dos demais critérios para que se proceda à distinção entre as ilicitudes.

Para que se observe a distinção entre os ilícitos penal e administrativo sancionador, a doutrina indica três aspectos: a análise das racionalidades (onde são descartados os critérios de distinção que não se adequam aos requisitos do nível de racionalidade) e os juízos interno (são escolhidos dentro de cada nível os critérios mais apropriados de acordo com o julgamento da eficiência deste nível) e externo (onde são confrontados os critérios selecionados, em cada nível, com os restantes dos demais níveis). Isso demonstra, por si só, o quanto é difícil a distinção entre o ramo penal e o administrativo para os técnicos. Imagine-se para o cidadão, a quem não se considera ponderar os níveis de racionalidade retroapresentados.

De fato, é no âmbito da eficiência que se traz à colação os aspectos examinados nos demais níveis de racionalidade e que se prestam a uma distinção das ilicitudes penal e administrativa, no intuito em que se direcionem decisões político-jurídicas quanto à temática. Veja-se:

a) Nível ético. $\mathrm{O}$ argumento mais adequado para a distinção reside na percepção de que a ilicitude penal é aquela que busca fazer frente aos ataques às bases de convivência mais arraigadas nas convicções sociais. Trata-se, pois, da ponderação quanto a um núcleo duro do direito penal e ataques dolosos a bens jurídicos vitais, como a vida, liberdade, autodeterminação sexual etc.

\footnotetext{
${ }^{670} \mathrm{O}$ que certamente é mais fácil de realizar no âmbito das infrações fiscais.

${ }^{671}$ ATIENZA RODRIGUEZ, Manuel. op. cit., p. 93-94.
} 
Neste âmbito, é possível que haja alguma colidência com a racionalidade pragmática, especialmente quando verificados resultados de pouca monta/lesividade. Diante disso, a solução mais correta deveria ser a manutenção/prevalência da racionalidade ética. Neste sentido, não é viável valer-se do argumento de que apenas o direito penal busca repelir ataques a condutas que violem valores éticos, restando à ilicitude administrativa aquelas desobediências desvinculadas de valores sociais ou menos vigorosas quanto aos aspectos éticos. Isto porque, em tese, toda e qualquer proibição imposta pelo Estado deve encontrar algum substrato de valores sociais relevantes, sob pena de haver proibição pura e simples, num viés claramente autoritário.

b) Nível teleológico. Os argumentos mais adequados à solução neste âmbito são o de que o direito Administrativo Sancionador deve perseguir primordialmente a proteção de setores relacionados com a atividade administrativa e o de que pode atuar como direito punitivo preventivo (direito administrativo voltado aos seus fins).

Neste âmbito pode haver conflitos com argumentos éticos tendo-se em vista que as lesões a bens jurídicos podem sugerir a incidência do Direito Penal no lugar do Administrativo Sancionador. Mas, nesses casos deveria haver a sobreposição do critério ético em detrimento do teleológico. Também poderia haver conflito com o nível ético na medida em que há uso da estrutura de perigo abstrato envolvendo o núcleo duro do direito penal. Igualmente a racionalidade teleológica deveria ceder em primazia da ética, remetendo ao direito penal a proteção dessas condutas.

c) Pragmático. Quanto às ponderações pragmáticas, os argumentos seriam voltados a uma maior efetividade, situação que elevaria a importância de questões relativas à agilidade do procedimento administrativo sancionador em face do Direito Penal. Todavia, possível conflito com a racionalidade ética poderia existir na medida em que a submissão a todo custo de infrações ao ramo Administrativo Sancionador poderia ser eticamente alvo do Direito Penal, passando a este outro ramo. A solução seria a manutenção de tais infrações no âmbito penal, ainda que se queira argumentar pela ineficácia penal em face de uma cifra negra (certos delitos que jamais serão conhecidos pela instância penal que melhor seria remeter sua apreciação ao Direito Administrativo Sancionador).

d) Nível jurídico-formal. Neste âmbito as relações entre o direito penal e o administrativo são permeadas por uma irracionalidade que deve ser revista $o$ quanto antes. Assim, são evitadas situações de bis in idem, aumentando-se a 
eficácia do direito punitivo. Isto se busca pela aplicação de política criminal e de controles de racionalidade quanto à edição de leis penais, possivelmente tornando o processo legislativo mais dificultoso para a edição de leis incriminadoras. Também se deveria estruturar, com mais cuidado, os tipos de perigo existentes no âmbito do direito administrativo sancionador, evitando-se que o direito administrativo tenha tipos de resultado e que o direito penal tenha tipos de perigo.

Eis, então, as ponderações sobre as distinções entre as esferas penal e administrativo-sancionadora que se pretendeu utilizar como ilustração da dificuldade em precisar o conhecimento da ilicitude penal. Passa-se, agora, a observações relativas ao tratamento do erro. 


\section{DO ERRO E SUA RELAÇÃO COM O CONHECIMENTO DA ILICITUDE}

\subsection{Considerações iniciais}

Um dos mais difundidos ditados de que se tem conhecimento - errar é humano representa perfeitamente algo intrínseco à natureza humana. Não à toa, há mais de trinta anos Assis Toledo já indicava que não poderia o Direito, que regulamenta os fatos humanos, deixar de ocupar-se com o mencionado fenômeno. ${ }^{672}$

O erro constitui um estado psicológico de desconformidade entre a consciência e a realidade e encontra-se intimamente relacionado com a estrutura do delito. Fato é que a ausência de qualquer representação ou mesmo havendo a percepção equívoca de um fato ou de uma norma jurídica, o processo de formação da vontade restará viciado, repercutindo em aspectos relacionados tanto à tipicidade quanto à culpabilidade. Então, o que se conhece por erro, situação que vicia a vontade pela falsa percepção da realidade, pode incidir tanto sobre elementos que constam da descrição típica, quanto sobre o desvalor da conduta. No primeiro caso tem-se o chamado "erro de tipo", ao passo que no segundo verifica-se o "erro de proibição". Tal distinção, no entanto, é complexa e comporta questionamentos doutrinários e jurisprudenciais.

Nesta perspectiva, o erro de tipo como excludente do dolo é algo que soa como pacífico na doutrina e jurisprudência. Por outro lado, caracteriza-se como atual grande dificuldade as buscas por uma fórmula que seja apta a conciliar as razões de utilidade pública que demandam aplicação das leis penais com independência de seu conhecimento pelo destinatário e o ideal de justiça e de equidade, que necessariamente devem compor a imperatividade do direito. Tudo isto com vistas a que a sanção decorra sempre da consciente rebeldia à ordem jurídica. ${ }^{673}$

No Brasil, os atuais erros de tipo e erro de proibição não correspondem aos antigos conceitos de erro de fato e erro de direito, sendo recomendável abdicar-se dos conceitos

\footnotetext{
${ }^{672}$ TOLEDO, Francisco de Assis. $O$ erro no direito penal, cit., p. 1.

${ }^{673}$ MUNHOZ NETTO, Alcides. Erro de fato e erro de direito no Anteprojeto de Código Penal. Revista da Faculdade de Direito da UFPR, n. 9, nov. 2006. Disponível em: <http://ojs.c3sl.ufpr.br/ojs2/index.php/direito/article/view/6695/4795>. Acesso em: 14 abr. 2012.
} 
passados com influências romanas e já não correspondentes ao tratamento dispensado nos dias de hoje. Assim, os atuais institutos do erro não representam mera atualização dogmático-normativa, mas verdadeira mudança conceitual, com novos propósitos e com maior abrangência. ${ }^{674}$

Destarte, o erro de tipo abarca casos em que seriam definidos como erro de fato, mas também outros, que seriam considerados à época, erro de direito. Por sua vez, o erro de proibição comporta novas situações, abrangendo igualmente casos em que seriam considerados erro de direito. É preciso consignar, no entanto, que o erro na esfera criminal será relevante quando inevitável ou insuperável.

Tendo-se alterado o sistema de normas que incide sobre o erro, não há correspondência com os antigos limites e conceitos, já que no passado a divisão se dava pura e simplesmente nas situações jurídica e fática. Segundo o regramento pátrio atual, o que se verifica é que estão em evidência a tipicidade e a ilicitude, sendo que sobre tais é que incorrerá o erro. ${ }^{675}$

Apesar desta organização institucional do erro mais atualizada, prevalecem alguns questionamentos, sejam relativos à sua aplicação prática em decisões judiciais, seja pela teoria a ser considerada para aplicação das consequências práticas. Além disso, ainda restam comentários a expor quanto às distinções erro de tipo e erro de proibição no contexto da expansão penal e, ainda, entre erro e ignorância. Eis por onde iniciaram as próximas explicações.

\subsection{Erro e ignorância}

É necessário distinguir, desta forma, erro de ignorância, embora se possa, inicialmente, entendê-los como sinônimos. Com uma apreciação ligeiramente detida sobre os mesmos pode-se verificar que expressam significados distintos. Frise-se que Assis Toledo, no final da década de 70, esclarecia haver predominância de que ambos integravam-se, fosse porque se entendia que o erro compreendia a ignorância, fosse porque

\footnotetext{
${ }^{674}$ MUNHOZ NETTO, Alcides. A ignorância da antijuridicidade em matéria penal. Rio de Janeiro: Forense, 1978. p. 10.

${ }^{675}$ BITENCOURT, Cezar Roberto. Erro de tipo e erro de proibição. São Paulo: Saraiva, 2010. p. 116.
} 
se entendia o inverso: que a ignorância compreendia o erro. ${ }^{676}$ Apesar disso, o próprio autor reconhecia que ignorância e erro não exprimiam o mesmo fenômeno e explicou que “costuma-se apontar a primeira como um estado negativo, isto é, a ausência de qualquer noção sobre o objeto do conhecimento. O agente desconhece simplesmente a existência do objeto. O segundo, diferentemente, é a falsa noção, é um estado positivo. Se na ignorância o conhecimento de algo falta, no erro ele chega a formar-se, mas de maneira falsa" ${ }^{677}$

Trilhando o caminho da distinção entre os institutos, tem-se, portanto, que a ignorância nada mais é que um estado de absoluta ausência de conhecimento, o que se contrapõe, ao menos em parte, ao erro, que é um estado positivo e que depende de uma falsa percepção da realidade. Já dizia Carrara que "a ignorância consiste na ausência de qualquer noção relativa a um objeto; o erro, numa noção falsa acerca de um objeto. A ignorância é um estado negativo do espírito; o erro, um estado positivo. ${ }^{678}$

Munhoz Netto, por sua vez, logo no início de sua obra afirmava algo semelhante, esclarecendo que a ignorância mostra-se desacompanhada de qualquer percepção da realidade, e o erro tem determinação a partir de percepção desconforme àquela. ${ }^{679}$ Também Paulo José da Costa Junior já dizia que "ignorar é não saber", o que pode ser representado por um estado negativo, ao passo que "errar é saber mal", o que pode ser representado por um estado positivo, já que há conhecimento, todavia equivocado. ${ }^{680}$

Antolisei e Jiménez de Asúa igualmente se imiscuíram em ponderações sobre as diferenças entre o erro e a ignorância. O primeiro afirmou que uma das distinções entre o erro e a ignorância é que quanto a esta há absoluta falta de conhecimento enquanto o erro implica certo convencimento. ${ }^{681}$ Já o espanhol discorreu no sentido de que a ignorância pressupõe a total falta de representação consistente em completa falta de noção sobre um objeto determinado; por seu turno, o erro pressupõe representação equivocada de um

\footnotetext{
${ }^{676}$ TOLEDO, Francisco de Assis. O erro no direito penal, cit., p. 2. Esclarece o autor que Savigny entendia que o erro integrava a ignorância, ao passo que Manzini e Maggiore entendiam o contrário. Ademais, esclarecia que tal posicionamento havia se irradiado nos Códigos da época, tanto no civil quanto no penal.

${ }^{677}$ TOLEDO, Francisco de Assis. O erro no direito penal, cit., p. 3. No mesmo sentido: JIMÉNEZ DE ASÚA, Luis. Tratado de derecho penal. Buenos Aires: Editorial Losada, 1962. t. 6, p. 313.

${ }^{678}$ CARRARA, Francesco. Programa do curso de direito criminal: parte geral. Trad. Ricardo Rodrigues Gama. Campinas: LZN, 2002. v. 1, p. 196.

${ }^{679}$ MUNHOZ NETO, Alcides. A ignorância da antijuridicidade em matéria penal, cit., p. 1.

${ }^{680}$ COSTA JUNIOR, Paulo José da. Comentários ao Código Penal: parte geral. São Paulo: Saraiva, 1986. p. 182.

${ }^{681}$ ANTOLISEI, Francesco. Manual de derecho penal: parte general. 8. ed. Trad. Jorge Guerrero e Marino Ayerra Redín. Bogotá: Temis, 1988. p. 287.
} 
objeto certo. ${ }^{62}$ Em suma, a ignorância consiste na completa falta de conhecimento, enquanto o erro consubstancia-se num conhecimento falso.

Não obstante terem significados distintos, por vezes se lhe atribui efeitos jurídicos iguais, já que ambos incidem sobre a representação dos fatos de forma a tornar viciada a formação da vontade e levando o agente a praticar conduta diversa da que seria desejada caso tivesse a perfeita noção da realidade. Pode-se dizer, por um lado, que o erro e a ignorância repercutem quanto ao dolo e, ainda, quanto ao conhecimento da ilicitude já que interferem na livre apreciação do que é lícito e ilícito. Por outro lado, não se pode aceitar que ambos os termos tenham tratamento jurídico uniforme, fazendo com que situações distintas tenham tratamento equivalente. Nesse sentido, efetivamente a ignorância da lei seria algo como a situação de alguém que desconhece a existência daquela. Isso não impede, todavia, que saiba o agente que sua conduta é reprovável.

Por outro lado, o erro de proibição tem relação com o desconhecimento, por parte do agente, de que sua atuação contraria o direito. Trata-se, pois, da relação entre a conduta e a norma prevista no tipo penal, sendo que o agente, com base em equivocada representação, não imagina que atua contrariamente ao direito, sendo que será nesta relação entre a conduta do agente e a proibição ou mandado que encontra o foco da discussão sobre haver ou não o conhecimento da ilicitude. Sobre tal situação Munhoz Netto já dizia que o agente pode, ao ignorar a lei, desconhecer a classificação jurídica, as condições de aplicação e o quantum da pena, mas, ainda, assim, ter ideia da ilicitude de seu comportamento. ${ }^{683}$ Isso não ocorre, entretanto, ao desconhecer-se a ilicitude.

Assis Toledo dizia que a ilicitude não se encontra nem no fato nem nas leis, mas entre ambos, significando que a consciência da ilicitude reside na relação de contrariedade entre a conduta praticada e a totalidade do ordenamento jurídico, sendo possível conhecer as leis, desconhecendo-se a ilicitude do fato ou até mesmo ter a representação da ilicitude sem que se conheça a norma legal. ${ }^{684}$ Neste sentido Hungria também já se manifestou, especialmente quando asseverou que uma pessoa pode ter ciência de que certa conduta é incriminada em abstrato, todavia desconhecendo-a objetivamente, chegando até mesmo a

\footnotetext{
${ }^{682}$ JIMÉNEZ DE ASÚA, Luís. Princípios de derecho penal: la ley y el delito. Buenos Aires: Sudamericana, [s.d.]. p. 390.

${ }^{683} \mathrm{MUNHOZ}$ NETO, Alcides. A ignorância da antijuridicidade em matéria penal, cit., p. 20.

${ }^{684}$ TOLEDO, Francisco de Assis. Culpabilidade e a problemática do erro jurídico-penal. Revista dos Tribunais, São Paulo, v. 517, p. 255, dez. 1978.
} 
praticá-la. ${ }^{685}$ Precisamente, afirmou que "a consciência da injuridicidade pode faltar, não obstante o conhecimento específico da lei, do mesmo modo que pode ocorrer a despeito da ausência de tal conhecimento. Quando se diz consciência da injuridicidade, o que se quer exprimir é a consciência da oposição ao dever ético-jurídico, e o conhecimento deste não está indeclinavelmente adstrito à prévia certeza de que um artigo da lei penal especialmente reclama ou sanciona". ${ }^{686}$ Significaria dizer, em conformidade com as palavras de Hungria acima aludidas, que uma pessoa poderia não saber que a sonegação tributária pode representar crime previsto na Lei 8.137/90, no entanto sabendo que sua conduta é reprovável porque compreende que todos devem pagar impostos. Trata-se do caso em que se desconhece a lei, mas sabe-se da reprovação social de seu comportamento.

Figueiredo Dias, por seu turno, entende que o agente pode "ignorar ou não ter presente na sua consciência-psicológica, no momento de sua ação, a lei, o princípio ou a norma geral e abstrata efetivamente aplicáveis ao problema da ilicitude, e que contém a respectiva proibição ou imposição de ação, e, todavia, possuir a consciência da ilicitude relevante para a culpa". ${ }^{687}$ Verifica-se, pois, que nesse entendimento a possibilidade de conhecimento do ilícito se intensificará todas as vezes que a valoração jurídico-penal estiver inserida em contexto mais amplo, num âmbito moral, cultural ou social. ${ }^{688}$ Nesses casos não seria surpresa alguma se as pessoas conhecessem o ilícito.

Resta claro, portanto, que a ignorância distingue-se do erro por ser aquela mais abrangente, isto é, a ignorância é um estado negativo que reflete a total ausência de noção relativa a algo, sendo o erro uma percepção equívoca. Ou, nas palavras de Paulo José da Costa, "ignorar é não saber" e "errar é saber mal”. ${ }^{6}{ }^{6}$

\subsection{Desconhecimento do ilícito versus Desconhecimento da norma}

É preciso deixar claro que desconhecer a ilicitude de um fato é algo um tanto diferente de desconhecer-se a norma legal. Assis Toledo já dizia que "a ilicitude de um fato não está no fato em si, nem nas leis vigentes, mas entre ambos, isto é, na relação de contrariedade que se estabelece entre o fato e o ordenamento jurídico". 690

\footnotetext{
${ }^{685}$ HUNGRIA, Nelson. Comentários ao Código Penal, cit., v. 1, t. 2, p. 118.

${ }^{686}$ Id. Ibid., p. 120

${ }^{687}$ DIAS, Jorge de Figueiredo. O problema da consciência da ilicitude em direito penal, cit., p. 257.

${ }^{688}$ Id. Ibid., p. 258.

${ }^{689}$ COSTA JUNIOR, Paulo José. op. cit., p. 182.

${ }^{690}$ TOLEDO, Francisco de Assis. Princípios básicos de direito penal. São Paulo: Saraiva, 1985. p. 66.
} 
Há, todavia, presunção legal de conhecimento da norma por todos, de modo que a completa ignorância da lei não pode ser alegada para justificar a prática de um ilícito qualquer. Quer-se colocar que o erro de proibição relaciona-se com a culpabilidade, não se vinculando ao conhecimento da regra específica, pleiteando-se a revogação da mesma pelo desconhecimento. Em outras palavras: há uma relação entre a lei abstratamente considerada e o conhecimento que alguém possa ter sobre a conduta que viole a norma. Nesse contexto, isto é, entre a norma em abstrato (válida, eficaz) e o comportamento concreto, personificado na conduta de cada indivíduo, que se mostra presente ou ausente a consciência da ilicitude. Como dito, sendo algo relativo à culpabilidade, em nada se vincula unicamente ao reconhecimento normativo positivado.

Neste sentido, Munhoz Netto já havia prelecionado que "a diferença reside em que a ignorância da antijuridicidade é o desconhecimento de que a ação é contrária ao Direito. Por ignorar a lei, pode o autor desconhecer a classificação jurídica, a quantidade de pena, ou as condições de sua aplicabilidade, possuindo, contudo, representação da ilicitude do comportamento". ${ }^{691}$ Por isso Hungria havia mencionado que o conhecimento do ilícito não está indeclinavelmente adstrito ao desconhecimento da norma, isto é, à anterior convicção da existência de uma norma penal. ${ }^{692}$

O que determinou a reforma penal de 1984 é que o erro pode, em determinadas situações, ter reflexos no que tange à culpabilidade. De maneira alguma terá a força de abrogar a lei até porque, se o fizesse, geraria crise de insegurança. Assim, são coisas distintas a presunção relativa de que se conhece as leis abstratamente consideradas e, outra, bem diferente, é a verificação do erro de proibição e sua não reprovação minorada em certos casos. Para que reste ainda mais claro: o erro de proibição refere-se à concreta ausência no agente, no momento da conduta, da consciência sobre a ilicitude referente àquele ato. Quanto a isso, Alberto Silva Franco esclareceu que "a separação conceitual entre o erro de vigência e o erro sobre a ilicitude do fato, recomendada por amplos setores da doutrina, não foi desprezada pelo legislador de 84, que a levou na devida conta ao redigir o art. 21 da PG (Parte Geral). O texto legal foi estruturado em dois períodos: no primeiro, consagrou-se

\footnotetext{
${ }^{691}$ MUNHOZ NETO, Alcides. A ignorância da antijuridicidade em matéria penal, cit., p. 20.

${ }^{692}$ HUNGRIA, Nelson. op. cit., v. 1, t. 2, p. 118.
} 
o princípio de que o desconhecimento da lei é inescusável; no segundo, cuidou-se com exclusividade, do erro sobre a ilicitude do fato". 693

Karl Binding, por outro lado, já afirmou que na grande maioria dos casos, a alegação do desconhecimento da norma nada mais é que grosseira mentira, uma vez que o egoísmo mostra-nos os atos que não temos que suportar e, por isso, nossa razão demonstranos que tais atos devem ser proibidos quando praticados por outrem contra nós. ${ }^{64}$ Tal suposição bastaria para produzir o suficiente conhecimento da norma.

Ocorre que houve mudança quanto ao conceito de culpabilidade, entendendo-se que um dos seus elementos não é mais a plena consciência da ilicitude, mas apenas seu potencial conhecimento. Nesse contexto não se pode exigir conhecimento técnico-jurídico, mas algo sobre a antissocialidade ou lesividade da conduta. Já foi dito que se trata da "consciência profana do injusto", ${ }^{695}$ provida das normas de cultura, da vida em sociedade, adquiridos naturalmente, com o ar que se respira. ${ }^{696}$

Todavia, é preciso frisar que não se verifica a todo tempo a compatibilidade entre o dever jurídico e a moral, uma vez que o Direito se propõe a proteger situações muitas vezes contrastantes com a moral, por diversos motivos, incluindo-se aí a falta de uma política criminal efetivamente considerada pelo legislador. Entre nós, já se disse, inclusive, que a ação criminosa pode se mostrar até mesmo louvável ${ }^{697} \mathrm{e}$, mesmo doutrina estrangeira já se manifestou no sentido de que nem todos os crimes representam ações imorais porque há ações que são proibidas por motivos de segurança social. ${ }^{698}$ Além disso, nota-se que muitas vezes há relevantes diferenças sociais quanto às violações das normas, variando-se conforme o grupo social seja mais ou menos rico ou mais ou menos culto.

Mesmo com o imenso esforço para explicar as diferenças entre o desconhecimento da norma abstratamente colocada e o erro de proibição, há casos de difícil solução porque temos convivido com a expansão do Direito Penal e a inflação de tipos penais, em especial

\footnotetext{
${ }^{693}$ FRANCO, Alberto Silva; STOCO, Rui et al. Código Penal e sua interpretação. 8. ed. São Paulo: Ed. Revista dos Tribunais, 2007. p. 180. Vale frisar Alberto Silva Franco "erro de vigência", o desconhecimento da lei, diferenciando-o de erro sobre a ilicitude do fato.

${ }^{694}$ Apud KAUFMANN, Armin. Teoría de las normas, cit., p. 34-35.

${ }^{695}$ BITTENCOURT, Cezar Roberto. Tratado de direito penal: parte geral, cit., p. 376.

${ }^{696}$ Apud KAUFMANN, Armin. op. cit., p. 35.

${ }^{697}$ BITTENCOURT, Cezar Roberto. Tratado de direito penal: parte geral, cit., p. 376.

${ }^{698}$ FLORIAN, Eugenio. Trattato di diritto penale. Milano: Francesco Vallardi, 1910. v. 1, p. 308.
} 
os de perigo. Munhoz Netto já dizia que não estamos mais sob a égide da lei das XII tábuas, pelo que vivemos envoltos em um arsenal todo dia renovado. ${ }^{699}$

Bitencourt ilustra os comentários acima mencionados com dois exemplos. No primeiro, cita a pessoa que encontra coisa alheia, de dono desconhecido, e a mantém consigo, sem que a entregue à autoridade policial. Diante da autoridade policial declara que não a havia colocado à disposição da autoridade porque sempre teve a convicção de que tal obrigação só se apresentava quando conhecido o dono. E indaga: estaria alegando desconhecimento da lei ou erro sobre a ilicitude $?^{700}$ No segundo exemplo ilustra com o caso da pessoa que desconhece ter de pagar metade do valor do tesouro ao proprietário do terreno.

Foi por questões como essas que Welzel repensou o conceito de consciência da ilicitude, entendendo que a ele estava ínsito o dever de se informar. Desta forma, o que se verificou foi alteração no sentido de se passar a ter apenas a potencial consciência do ilícito. Neste sistema, a ausência do conhecimento não é suficiente para que se inocente alguém, sendo imperioso que se indague se existia alguma chance de ter aquela consciência. Em havendo, passa-se a verificar se houve descuido em não adquiri-la ou mesmo o dever concreto de esclarecimento. Isso significa que passaria a incidir um juízo de valor sobre as ações humanas, sendo o erro justificável apenas quando insuperável.

Insta frisar que o Código Penal Brasileiro não deixou de observar o posicionamento Welzeniano, de forma a prever no art. 21 que “é evitável o erro se o agente atua ou se omite sem a consciência da ilicitude do fato, quando lhe era possível, nas circunstâncias, ter ou atingir essa consciência". Eis a figura básica do erro de proibição, isto é, a impossibilidade de o agente obter entendimento sobre o desvalor da sua atuação e que está em sintonia com o que dispõe o art. $3^{0}$ da Lei de Introdução ao Código Civil, que dispõe "ninguém se escusa de cumprir a lei alegando que não a conhece".

Tais normas têm um cristalino componente de ordem prática: baseiam-se no fato de que o ordenamento jurídico não subsistiria caso as leis não se tornassem obrigatórias com a sua publicação porquanto haveria total insegurança jurídica ao permitir-se a qualquer pessoa a alegação de que descumpriu preceito legal porque não o conhecia. É, então, em prol da subsistência da ordem jurídica que o legislador optou por determinar que a publicação das normas faça presumir o conhecimento delas por todos. Pode-se dizer que

\footnotetext{
${ }^{699}$ MUNHOZ NETO, Alcides. A ignorância da antijuridicidade em matéria penal, cit., p. 61.

${ }^{700}$ BITTENCOURT, Cezar Roberto. Tratado de direito penal: parte geral, cit., p. 377.
} 
isso se funda numa ficção legal para afastar a insegurança jurídica. Guillermo Borda já assinalava que as leis não poderiam ser burladas sob a rubrica de alegações relativas ao seu desconhecimento, porque isso autorizaria qualquer pessoa, a todo o momento, fazer uso dessa "defesa", tornando impossível a aplicação das normas em geral. ${ }^{701}$

Com as explanações acima se quer deixar claro que o princípio da ignorantia legis neminem excusat mostra-se como verdadeiro fundamento de validade para a aplicação da lei, não devendo ser considerado, todavia, como princípio norteador para o reconhecimento da existência ou da falta de consciência da ilicitude.

\subsection{Do erro de tipo e do erro de proibição}

Considerando-se o ramo penal, erro é a equivocada percepção da realidade. Embora seja possível diferenciar os termos "erro" de "ignorância", sendo o primeiro a falsa percepção e o segundo o completo desconhecimento, para o Direito Penal podem ser tidos como sinônimos.

É bem verdade que o erro pode interferir como de fato interfere na reprovação penal do agente, podendo até mesmo excluir o autor da conduta de responsabilidade. E, por isso mesmo, cabe salientar precisamente as diferenças entre os institutos.

O erro de tipo é expressão derivada de outra, mais extensa: erro sobre elemento do tipo refere-se ao equívoco quanto a algo que constitui o tipo penal. Assim, pouco importa que a falsa percepção refira-se a algo relativo ao mundo fático, conceitual ou mesmo às normas jurídicas. ${ }^{702}$ Importa, no entanto, que faça parte da estrutura típica.

Vale dizer que a confusão que se faz quanto à realidade é que enseja o erro de tipo, desde que um elemento básico da redação tenha sido incluído nesta confusão. Há verdadeira confusão fática. Exemplifica-se. Uma pessoa que ao sair de um estabelecimento comercial dirige-se a automóvel idêntico ao seu (mesmo modelo, mesma cor) e tenta nele ingressar, portanto não atento à realidade, está tentando subtrair coisa alheia móvel, situação que se subsume ao tipo penal de furto. O verdadeiro proprietário do automóvel,

\footnotetext{
${ }^{701}$ BORDA, Guillermo. Error de hecho y de derecho: su influencia en la anulación de los hechos jurídicos. Buenos Aires: Perrot, 1950. p. 97.

${ }^{702}$ MAURACH, Reinart. Tratado de derecho penal. Trad. Juan Córdoba Roda. Barcelona: Ariel, 1962. t. 2, p. 336.
} 
caso visse a cena, provavelmente pensaria estar sendo vítima de furto. Note-se que o erro incide sobre dado elementar do tipo, isto é, sobre "coisa alheia móvel", pensando-se que sua atuação era de bona fide.

A doutrina menciona, ainda, a possibilidade de incidir o erro de tipo em crimes omissivos impróprios, como o caso do pai que, ignorando ser seu filho a pessoa que está se afogando no mar, deixa de prestar socorro. ${ }^{703} \mathrm{O}$ erro, in casu, incide sobre a posição de garantidor.

Já o erro de proibição é o que incide sobre a ilicitude do comportamento, representando juízo equivocado do que o ordenamento lhe autoriza fazer. Não se relaciona com o fato praticado, mas com o juízo que se faz sobre tal comportamento à vista do que propõe o sistema. No erro de proibição não incide qualquer juízo equivocado sobre os fatos diante dos olhos do autor, sabendo este exatamente o que faz. A confusão dá-se quanto à compreensão da regra de conduta. Em suma bastante apertada, o agente sabe o que faz, desconhecendo-se que tal conduta é proibida.

Já se disse que é preciso ter em mente "a lei, o fato e a ilicitude. A lei, como proibição, é entidade moral e abstrata; o fato, como ação, é entidade material e concreta; enquanto a ilicitude é a relação de contradição entre a norma e o fato. Pois bem, como discutido, o erro de proibição incide, justamente, sobre este último fator, ou seja, sobre a relação de contradição do fato com a norma", 704

Welzel $^{705}$ já explicou que aquele que "subtrai coisa que erroneamente supõe ser sua, encontra-se em erro de tipo: não sabe que subtrai coisa alheia”. E acrescenta, posicionando-se sobre o erro de proibição, dizendo que "quem acredita ter o direito de subtrair coisa alheia, encontra-se em erro sobre a antijuridicidade”. E, ainda, Maurach já esclareceu que o "erro de tipo é o desconhecimento de circunstâncias do fato pertencentes ao tipo legal, com independência de que os elementos sejam descritivos ou normativos, jurídicos ou fáticos. Erro de proibição é todo erro sobre a antijuridicidade de uma ação conhecida como típica pelo autor", ${ }^{706}$

\footnotetext{
${ }^{703}$ BITTENCOURT, Cezar Roberto. Tratado de direito penal: parte geral, cit., p. 384.

${ }^{704}$ COELHO, Walter. O direito penal e o novo Código Penal brasileiro (coletivo). Porto Alegre: Sergio Antonio Fabris Editor, 1985. p. 100.

${ }^{705}$ WELZEL, Hans. Derecho penal alemán. Trad. Juan Bustos Ramirez y Sergio Yañez Pérez. Santiago: Ed. Jurídica de Chile, 1987. p. 233.

${ }^{706}$ MAURACH, Reinart. Tratado de derecho penal, cit., t. 2, p. 142.
} 
Por fim, é preciso deixar cristalino que, caso as normas fossem absolutamente obrigatórias mesmo aos que a desconhecem, não haveria razão para não aplicá-las ao mentalmente incapaz. ${ }^{707}$ Ao menos da forma que se promove sua aplicação.

\subsection{Dos dispositivos legais relacionados ao erro de tipo e de proibição}

É o art. 20 do CP que traz o primeiro tratamento no que se refere ao erro de tipo, determinando que "o erro sobre elemento constitutivo do tipo legal de crime exclui o dolo, mas permite a punição por crime culposo, se previsto em lei”.

Também o código traz regramento quanto às descriminantes putativas, em que o erro também se mostra presente. Assim, o $\$ 1^{\underline{0}}$ do art. 20 determina que "é isento de pena que, por erro plenamente justificado pelas circunstâncias, supõe situação de fato que, se existisse, tornaria a ação legítima. Não há isenção de pena quando o erro deriva de culpa e o fato é punível como crime culposo".

Inobstante, ainda há outros dois dispositivos legais importantes. O primeiro é o $§ 2^{\underline{0}}$ do mesmo art. 20, que atribui responsabilidade penal ao terceiro que determina o erro. $\mathrm{O}$ outro se refere ao erro quanto à pessoa, prescrevendo que, nesse caso, o erro contra a pessoa que se quis cometer o crime não isenta o autor de pena, impondo-se que a ele considerem-se, para fins de punição, as condições ou qualidades da pessoa que se desejava vitimar e não a efetivamente atingida.

Assim, nota-se que existe uma subdivisão que se pode considerar quanto ao erro: essencial e acidental. No primeiro caso, exclui-se o dolo, amenizando ou até mesmo isentando a responsabilidade penal do agente. No caso do erro acidental, não haverá benefícios ao autor do crime.

O erro essencial pode ser subdividido em erro de tipo incriminador (art. 20, caput) e erro de tipo permissivo (art. $20, \S 1^{\underline{0}}$ ).

Já o erro acidental pode verificar-se em três situações: erro quanto ao objeto material (art. 20, $\S 3^{\circ}$ ), erro na execução (arts. 73 e 74 ) e o erro quanto ao nexo causal (não expresso na lei).

\footnotetext{
${ }^{707}$ MUNHOZ NETO, Alcides. A ignorância da antijuridicidade em matéria penal, cit., p. 63.
} 
Por seu turno, especificamente quanto ao assunto do erro de proibição, antes de qualquer coisa é de se apontar o disposto no art. $3^{\circ}$ do decreto-lei 4.657/42, autonomeado como lei de introdução ao código civil. Referida norma dispõe que: "Ninguém se escusa de cumprir a lei, alegando que não a conhece" e, por muitas e muitas vezes se torna foco das perguntas e comentários sobre o erro de proibição. Afinal - dizem -, se a lei é presumidamente conhecida por todos, como compatibilizá-la com a potencial consciência da ilicitude? Trata-se, obviamente, de norma que proíbe a alegação do desconhecimento da existência da norma, como componente do ordenamento e não se relaciona com o efetivo desconhecimento da proibição sobre certos comportamentos.

No Código Penal é o art. 21 que determina que "o desconhecimento da lei é inescusável. O erro sobre a ilicitude do fato, se inevitável, isenta de pena; se evitável, poderá diminuí-la de um sexto a um terço". Relativamente ao erro de proibição, está relacionado diretamente com a potencial consciência da ilicitude, elemento da culpabilidade. Assim, estando em erro de proibição, fica afastada a culpabilidade, segundo entendimento majoritário na doutrina pátria. Ocorre que também há subdivisão quanto a este erro, havendo as modalidades: vencível e invencível, também conhecidas, respectivamente, por inescusável e escusável. No primeiro caso, constata-se que o agente tinha condições de ter adquirido tal conhecimento e, no segundo caso, entende-se que o agente não teria condições de alcançar a compreensão. As consequências também são distintas ao passo que, no primeiro caso, a pena não é aplicada e, no outro, a pena será reduzida.

Deve-se mencionar, ainda, que apesar de a lei brasileira dispor que é inescusável o desconhecimento dos preceitos legais, reconhece-se que a ignorância leva a uma atenuação da pena (art. 65, II, CP). ${ }^{708}$ Ademais, não se pode deixar de mencionar que a Lei das Contravenções Penais, ${ }^{709}$ no art. $8^{\underline{0}}$ autoriza o perdão judicial para casos de ignorância escusável.

Assim, é de se assinalar que embora nosso ordenamento jurídico disponha que é inescusável o não conhecimento da lei, há certa mitigação por causa do erro sobre a ilicitude. Nesse sentido, Juarez Cirino esclarece que: "essa sistematização do erro de proibição na lei penal brasileira se baseia na premissa de que a regra da inescusabilidade

\footnotetext{
${ }^{708}$ Art. 65 - São circunstâncias que sempre atenuam a pena: (Redação dada pela Lei $n^{0} 7.209$, de 11.7.1984). (...)

II - o desconhecimento da lei; (Redação dada pela Lei no 7.209, de 11.7.1984).

${ }^{709}$ Decreto-lei 3.688/41.
} 
do desconhecimento da lei (art. 21, CP, primeira parte) é limitada pelas exceções representadas pelo erro de proibição inevitável (art. 21, CP, segunda parte) - o erro de proibição evitável apenas gradua a reprovação". A interpretação de que a regra da inescusabilidade do desconhecimento da lei não prevalece sobre as exceções do erro de proibição inevitável pode extinguir a tensão entre política criminal e princípio da culpabilidade, em matéria de erro de proibição direto, sob a modalidade de desconhecimento da norma ou da lei penal na literatura e jurisprudência brasileiras. Se o Direito Penal do moderno Estado Democrático de Direito assenta no princípio da legalidade, expresso na fórmula nullum crimen sine lege, que fundamenta a incriminação das condutas, e no princípio da culpabilidade, expresso no princípio nullum crimen sine culpa, que fundamenta a responsabilidade e a criminalização individual, então a lei ordinária não pode, em nenhuma hipótese, contrariar esses princípios e, portanto, o princípio da culpabilidade não pode ser cancelado para garantir a eficácia da lei penal, como pretende um setor da literatura penal brasileira. Não é o princípio da culpabilidade que deve se adequar à lei, mas a lei que deve se adequar ao princípio da culpabilidade, sob quaisquer critérios de interpretação. ${ }^{710}$

\subsection{Formas ou modalidades do erro de proibição admitidos no Brasil}

O grau de reprovação deve ser diferenciado considerando-se quem age sem saber todavia podendo saber, e quem age efetivamente sabendo, conhecendo a ilicitude. Em suma, pode-se dizer que no Brasil aquele que age com a consciência real recebe reprovação normal, ao passo que aquele que atua com a consciência potencial tem reprovação reduzida e, por fim, aqueles sem potencial consciência não sofrem reprovação.

Inescusável é o erro superável, que podia ser evitado, isto é, aquele que com algum cuidado não teria ocorrido porque era possível ter a consciência da ilicitude; e, escusável é justamente a situação que deveria ser perdoada porque não se tinha a possibilidade de conhecer o caráter ilícito da conduta.

Quanto à diferenciação do erro de proibição, pode-se dizer que há basicamente três modalidades: o erro de proibição direto, o indireto e o mandamental. Independentemente

\footnotetext{
${ }^{710}$ SANTOS, Juarez Cirino dos. A moderna teoria do fato punível. Rio de Janeiro: Freitas Bastos, 2000. p. 242-243.
} 
disso, qualquer deles pode se apresentar sob a óptica da escusabilidade, sendo perdoáveis ou não.

O erro de proibição direto se dá na situação em que o agente equivoca-se quanto à norma proibitiva. Assim, sua conduta é ativa, praticando ação porque desconhece a proibição ou porque a conhece mal. De qualquer forma, age equivocadamente.

Também se menciona a possibilidade do erro sobre a ilicitude ocorrer quanto a crimes culposos, já que o tratamento dispensado pelo art. 21 do $\mathrm{CP}$ não especifica quanto à necessidade do dolo. Destarte, perfeitamente possível que o agente se equivoque quanto a um seu dever de cuidado objetivo.

No que tange ao erro mandamental, é o que se dá quanto aos crimes omissivos. É o que recai sobre norma mandamental, isto é, que impõe um agir, podendo se dar quanto a crimes omissivos próprios ou impróprios. Caso uma pessoa não preste socorro a outra porque crê sinceramente que não está obrigada a tanto seja porque não se vê vinculada à vítima, seja porque não concorreu para o perigo ou, ainda, porque entende que tal dever pertenceria aos demais, tem-se o erro de proibição.

Por fim, o erro de proibição indireto é o que Jescheck denominou erro de permissão. ${ }^{711}$ Isto porque o agente não só desconhece a ilicitude como também supõe erroneamente que exista norma permissiva.

\subsection{Erro de proibição e bem jurídico num contexto de expansão do Direito Penal}

Feitas as considerações sobre a evolução dos estudos do ramo penal e, ainda, sobre as modalidades de erro, ponderando-se, ainda, a realidade da expansão penal, especialmente quanto à administrativização penal, já se tem elementos para que se possa afirmar que a incidência do erro de proibição (direto) é mais comum quando incide sobre bens jurídicos que não nucleares.

Tal constatação pode ser corroborada, inclusive, por julgados que compõem a jurisprudência pátria, que demonstram que a consciência da ilicitude de condutas que lesam bens jurídicos transindividuais não é assimilada pelas pessoas da mesma forma que outras condutas, que ofendem bens jurídicos tradicionais, nucleares, ligados mais

\footnotetext{
${ }^{711}$ JESCHECK, Hans-Heinrich. Tratado de derecho penal: parte general, cit., 4. ed., p. 632.
} 
diretamente à individualidade (vida, liberdade, patrimônio). As ações e omissões que violam ou expõem a perigo bens jurídicos nucleares são, no mais das vezes, reconhecidas como ilícitas dentro de um contexto leigo sobre o que seja a ilicitude, não sendo exigidos conhecimentos profundos ou especiais para que se atinja a consciência da ilicitude.

Quanto a isso, Juarez Cirino dos Santos já afirmou que seria mais provável verificar-se o erro de proibição quanto aos bens jurídicos transindividuais porquanto os cidadãos teriam mais dificuldade em reconhecer a ilicitude concreta do tipo penal respectivo, sendo que nem mesmo os operadores do direito conhecem a totalidade das normas. $^{712}$

De fato, cumpre apontar que o reconhecimento da existência de um direito penal composto por "casos ordinários" e "extraordinários" (leia-se bens nucleares e bens especiais) já se encontrava presente nos estudos de Ferri, desde 1927. Este autor afirmou que "nos casos ordinários, será também impossível ao acusado provar sua absoluta boa-fé, mesmo que materialmente não conheça as disposições da lei, não só porque as experiências da vida quotidiana (e tanto mais as da própria e específica atividade profissional) fazem tomar conhecimento das proibições e restrições legais, mas também porque depois a consciência dos homens normais adverte da ilicitude de certas ações dolosas, culposas ou contravencionais. Há, porém, casos extraordinários, em que a aplicação de uma sanção penal repugna ao senso moral quando o imputado prove que, em virtude de força maior, esteve na impossibilidade de ter conhecimento daquela lei. Nestes casos, o acusado não agiu contra jus, nem por dolo, nem por negligência, e não tendo, portanto, transgredido o mínimo de disciplina social, o seu ato (não repugnante, por si, ao senso moral e às normas de conveniência) fica negativamente justificado. ${ }^{713}$

Igualmente, Antônio José da Costa e Silva adverte que: “os romanos, como se sabe, distinguiam entre a norma de mera creação política e as outras. Apoiando-se nessa distinção, alguns criminalistas, da velha e nova data, têm pretendido que se estabeleça diferença, relativamente à eficácia do error juris, entre as ações cuja índole criminosa é patente (delicta juris gentium) e aquelas que não se revestem dessa natureza (delicta juris civilis)". ${ }^{714}$ A referida diferença entre a norma de mera criação política e outras, matizando

\footnotetext{
${ }^{712}$ SANTOS, Juarez Cirino dos. op. cit., p. 240.

${ }^{713}$ FERRI, Enrico. Princípios de direito criminal: o criminoso e o crime. Trad. Luiz de Lemos D'Oliveira. Campinas: Russel, 2003. p. 409.

${ }^{714}$ SILVA, Antonio José Costa e. Codigo Penal dos Estados Unidos do Brasil commentado. São Paulo: Companhia Ed. Nacional, 1930. p. 163.
} 
a aplicação do princípio da irrelevância do erro de direito indica que os romanos já levavam em conta a natureza do bem jurídico envolvido no conflito.

Fato é que o juízo de reprovação verificado pela análise da culpabilidade de alguém que pratica conduta tipificada e considerada ilícita tem respaldo com base na opção do agente que, podendo motivar-se de acordo com a norma, preferiu pela sua infringência. Para Jescheck, a consciência da ilicitude integra a culpabilidade porquanto a decisão da conduta típica, havendo o pleno conhecimento da norma jurídica que veda a tal conduta, representa a mais cristalina ausência de atitude jurídica pelo autor. Nesse sentido, a mensagem legal de que se comporte em obediência à lei deveria ter imediatamente repercutido em sua consciência, formando sua vontade pelo respeito às normas, mas, se pelo contrário, optou o agente por conscientemente agir contra o direito, mostra-se em atitude contraposta à do cidadão legalmente responsável. ${ }^{715}$

Pressupõe-se, pois, que para a observação dos preceitos legais ou a decisão pelo enfrentamento das normas, violando-as, o agente conheça a norma tipificada, fazendo atuar sua liberdade de escolha. Em outras palavras, para que o agente possa tomar a decisão de agir conscientemente pelo ilícito, é preciso conhecer a ilicitude de seu comportamento. Em suma, uma vontade somente poderá ser conscientemente dirigida contra o direito quando se conhece a proibição, de forma que, do contrário, estar-se-ia agindo com a certeza de que atua em sintonia com as leis. Jakobs tem entendimento nesse sentido, isto é, indica que a culpabilidade é a reprovabilidade de modo que pelo juízo de valor negativo (culpabilidade) é que estabelecerá reprovação ao autor que, podendo agir em conformidade pelo direito, optou por infringi-lo. O fundamento para tanto é a capacidade de autodeterminação das pessoas em decidirem-se, livre e responsavelmente pela ilicitude de suas condutas, sendo que, para essa tomada de decisão é preciso conhecer o direito e o ilícito. ${ }^{716}$

Entre nós, pode-se citar Hungria, para o qual "para que a ação materialmente em oposição ao dever seja imputável subjetivamente ao agente, ou para que este se torne responsável por sua conduta objetivamente contrária ao dever, é preciso que tenha tido a consciência ou a possibilidade de consciência dessa antinomia com o dever. Sem a falta consciente ou grosseira desatenção ao dever, não se concebe, sob o prisma ético, ação culpada". ${ }^{717}$ No mesmo sentido é a lição de Assis Toledo: "será fácil, aliás, compreender a

\footnotetext{
${ }^{715}$ JESCHECK, Hans-Heinrich. Tratado de derecho penal: parte general. Trad. Santiago Mir Puig e Francisco Muñoz Conde. 3. ed. Barcelona: Bosch, 1981. p. 622.

${ }^{716}$ JAKOBS, Günther. Estudios de derecho penal, cit., p. 374.

${ }^{717}$ HUNGRIA, Nelson. op. cit., p. 122.
} 
impostergável exigência desse novo elemento para a complementação do juízo de culpabilidade, se aceitar a conclusão evidente por si mesma de que não se pode emitir um juízo de reprovação em relação ao agente que, ao cometer o fato, não sabia nem tinha a possibilidade de saber o exato significado daquilo que fez". ${ }^{718}$ Isso - diga-se - está em sintonia também com as ideias de Muñoz Conde, que pondera só haver sentido falar-se em culpabilidade e, consequentemente em reprovação em relação aos que conhecem que atuam contrariamente ao que dispõem as normas. ${ }^{719}$ Assim, qualquer força motivadora que se queira atribuir às normas só poderá exercer alguma eficácia quanto às pessoas se o agente em questão tiver consciência da proibição, uma vez que, do contrário, não teria razoáveis motivos para abster-se de qualquer comportamento. ${ }^{720}$

O conhecimento aqui mencionado não se refere ao conhecimento da norma, mas deveria ter relação com critérios éticos, sociais e morais. Trata-se de consciência agregada no tempo, durante anos, ao longo da vida, ${ }^{721}$ porquanto há "valores básicos admitidos como objetivos consagrados pelo meio social e que guiam a instituição de regras convencionais transmitidas de geração em geração". ${ }^{722}$ Isto reflete que os pessoas fazem parte de um processo de socialização, o que se dá no tempo pela absorção de valores fundamentais, o que forma a consciência da ilicitude, refletida como o que é aprovado e desaprovado no meio social (o que é moralmente aceito ou rejeitado socialmente).

Precisamente quanto à influência dos valores humanos pode-se citar Figueiredo Dias, que entende que "o ser-livre não existe sozinho ou independentemente de seus conteúdos, antes se realiza neles e, portanto, em um mundo onde a própria vida reage sobre ele. Deste modo, a subsistência do ser-livre recebe-a não apenas do existente, mas também das normas de valor que possibilitam sua máxima realização. Por isso mesmo é que o direito fica legitimado a fazer exigência (participantes do dever-ser ético-existencial) à personalidade do homem; tais exigências, que este 'tem que' cumprir e por isso se lhe apresentam como tarefa, integram o 'valor da personalidade' que caracteriza o homem

\footnotetext{
${ }^{718}$ TOLEDO, Francisco de Assis. Princípios básicos de direito penal., cit., 1994, p. 256.

${ }^{719}$ MUNÕZ CONDE, Francisco; GARCIA ARÁN, Mercedes. Derecho penal: parte general. 2. ed. Valencia: Tirant Lo Blanch, 1996. p. 400.

${ }^{720}$ Id. Ibid.

${ }^{721}$ Ronaldo Tanus Madeira esclarece que: "desde a mais tenra infância, por meio de nossa consciência, até a idade madura, recebemos uma série de informações decorrentes de nossa vida familiar, social, educacional, profissional e religiosa. Essas informações nos tornam capazes, sem maiores dificuldades e sem profundas reflexões, de aprender um conhecimento natural e espontâneo do que é justo e em favor do direito e do que injusto e em favor do antijurídico". In: MADEIRA, Ronaldo Tanus. A estrutura jurídica da culpabilidade. Rio de Janeiro: Lumen Juris, 1999. p. 55.

${ }^{722}$ REALE JÚNIOR, Miguel. Instituições de direito penal: parte geral. Rio de Janeiro: Forense, 2002. p. 3.
} 
suposto pela ordem jurídico-penal". ${ }^{723}$ Por seu turno, Mommsen, relatando a natureza e limites do direito penal romano, lembra que a questão do caráter ético se relaciona à outra: a da necessidade do conhecimento, pelo agente, da lei penal, sendo que não raro a desconhece. $^{724}$ Nesse sentido, para o autor, o delito representa a violação de um dever moral, mas tal dever e seus limites podem não restar claro em cada norma, até mesmo porque a lei poderá ser injusta e não estar em sintonia com os princípios éticos que lhe devem servir de base. ${ }^{725} \mathrm{O}$ mesmo autor recorda, ainda, que as leis romanas, por vezes, fundavam-se em motivos de oportunidade, deixando de lado os princípios éticos prevalentes no seio da comunidade. ${ }^{726}$ Assim, esclareceu que "o direito romano procurava investigar as bases éticas a que se tinha de sujeitar a lei penal positiva, porém não desconhecia que a faculdade de legislar nesta ordem se estendia também, por puros motivos de imprescindível oportunidade, ou reputados como tais, a certas ações ou omissões moralmente indiferentes e não consideradas como injustas", 727

Figueiredo Dias já apontava que em Ética a Nicômaco, Aristóteles delineava argumentos para que se pudesse fundamentar a irrelevância do erro que recaísse sobre normas de direito natural. Assim, apontou que o filósofo já distinguia o erro sobre a universalia daqueles sobre os singularia. ${ }^{728} \mathrm{O}$ erro sobre os universalia seriam aqueles incidentes sobre regras com cunho de moralidade, que todos deveriam ter conhecimento, sendo igualmente de fácil percepção, por isso indesculpável e irrelevante. Por outro lado, o erro sobre os singularia poderiam ser desculpáveis e relevados. Para o citado autor, Aristóteles igualmente fazia distinção entre o direito de origem natural e o de origem legal, dando-se azo à fundamentação da irrelevância do erro que tivesse relação com normas de direito natural. ${ }^{729}$ Em suas explicações, no entanto, vai além e cita que já em Kant não se admitia o erro relativo à obrigatoriedade das leis morais naturais porque estas, por estarem gravadas na razão, não poderiam ser desconhecidas. Isto é, quanto a elas, o erro seria inescusável; todavia, quanto às normas positivas seria possível o reconhecimento de erros, uma vez que se poderia agir sem culpa, derivada esta ação de uma consciência equívoca. ${ }^{730}$

\footnotetext{
${ }^{723}$ DIAS, Jorge de Figueiredo. Liberdade, culpa e direito penal. 3. ed. Coimbra: Coimbra Ed., 1995. p. 176. ${ }^{724}$ MOMMSEN, Teodoro. Derecho penal romano. Trad. P. Dorado. Reimpressão. Bogotá: Temis, 1999. p. 64. ${ }^{725}$ Id. Ibid.

${ }^{726}$ Id. Ibid.

${ }^{727}$ Id. Ibid.

${ }^{728}$ DIAS, Jorge de Figueiredo. O problema da consciência da ilicitude em direito penal, cit., p. 104.

${ }^{729}$ Id. Ibid., p. 106.

${ }^{730}$ Id. Ibid., p. 114.
} 
Verifica-se, pois, que a essência ética pode determinar diferentes tratamentos penais para o instituto do erro sobre a ilicitude, conforme se esteja fundado ou não em normas proibitivas dos tipos penais. Também quanto a isso Figueiredo Dias se manifestou, fazendo diferenciação entre o chamado "direito penal de justiça" do "direito penal de mera ordenação", esclarecendo que, quanto ao primeiro a proibição é sentida pelas pessoas ainda que não se hajam tipos penais, isto é, independentemente da criação legislativa. ${ }^{731}$ Por outro lado, o direito penal de mera ordenação refere-se justamente à criação de leis, de modo que o erro de proibição, nestes casos, deve ser tratado como um "erro de facto" ou, ainda, "sobre a factualidade típica", excluindo-se o dolo. E, especialmente interessante a construção do autor português para justificar que, para o plano da culpabilidade, as práticas que violem normas são axiologicamente neutras, isto é, não revelam desvalor ligado ao dever ético. Em outras palavras, sendo a essência da valoração jurídica constituída pura e simplesmente pela proibição legal, então o fato de o agente conhecer a situação fática não lhe permite invocar sua consciência ética para que se posicione perante um desvalor que só existe por meio da proibição legal. Isto faz com que o erro do agente se torne verdadeiro desconhecimento, não um equívoco da sua consciência ética, de forma que não se poderá censurar a dissonância do seu juízo ético com os critérios verificáveis na ordem jurídica, mas apenas e tão somente sua falta de cuidado porquanto não exercido o dever de informar-se sobre a proibição. O que torna a conduta relevante, pois, é a censurabilidade típica por ter negligenciado conhecer da proibição. ${ }^{732}$ Dessa forma, o "direito penal de

\footnotetext{
${ }^{731}$ O chamado "Direito de Mera Ordenação Social" foi introduzido no ordenamento jurídico português em 1979 pelo Decreto-Lei no 232/79, de 24 de julho, no contexto da Reforma Penal que se concretizou em 1982, quando foi substituído pelo Decreto-Lei no 433/82, de 27 de outubro (define o regime geral em vigor daquele ramo do direito). De fato, relativamente àquele direito encontram-se preocupações de natureza político-criminal relativas a um novo ramo do sistema sancionatório público para passar a dar maior atenção a certas áreas de intervenção que o Estado não mais podia estar alheio, como é o caso da tutela do meio ambiente e dos direitos dos consumidores, por exemplo.

As novas disposições referiam-se a áreas consideradas carentes de tutela jurídica sancionatória porquanto se entendia que não era justificável resposta penal, isto é, situação na qual se notava o intenso desejo de aplicação de um direito penal de ultima ratio. Entendeu-se, portanto, ser necessário dar consistência prática a injunções normativas advindas da nova forma de intervencionismo estatal, de forma a demandar naturalmente um quadro específico de sanções. Surgia, assim, um novo ramo do direito sancionatório, autônomo do Direito Penal, como forma de garantir o princípio da subsidiariedade da intervenção penal, preservando-se o direito penal da atuação em casos de notória relevância. CORREIA, Eduardo. Direito penal e direito de mera ordenação social: direito penal económico e europeu: textos doutrinários Coimbra: Coimbra Ed., 1998. v. 1; Sobre o Direito das Contra-ordenações e a sua relação com o Direito Penal, cfr. DIAS, Jorge de Figueiredo. Direito penal: parte geral. Coimbra: Coimbra Ed. 2004. t. 1, p. 144 e ss. e CARVALHO, Américo A. Taipa de. Direito penal: parte geral. Porto: Publicações Universidade Católica, 2003. p. 147 e ss. e, ainda, PINTO, Costa. $O$ ilícito de mera ordenação social e a erosão do princípio da subsidiariedade da intervenção penal, direito penal económico e europeu: textos doutrinários. Coimbra: Coimbra Ed., 1998. v. 1, p. 212.

${ }^{732}$ DIAS, Jorge de Figueiredo. O problema da consciência da ilicitude em direito penal. 3. ed. Coimbra: Coimbra Ed., 1987. p. 400.
} 
justiça", no qual se podem verificar condutas violadoras da proibição legal, denota desvalor relacionado ao dever ético. Significa dizer que aspectos culturais, morais e sociais integram a noção do juízo que se fará sobre o que pretendem as normas. Nessa linha de raciocínio, então, ser o agente conhecedor da situação fática já lhe permitiria orientação da sua consciência ética a fim de que se posicione perante algo socialmente valorado negativamente, o que faria o erro, aqui, fundar-se num engano quanto à consciência ética e não mais uma falta de ciência. Por isso Figueiredo Dias entende que o conhecimento dos elementos típicos faz incorrer, ao agente, a consciência da ilicitude, não se admitindo como consequência a exclusão do dolo. Pelo contrário, censurar-se-ia o agente porque agiu com lacuna em sua consciência ética em face dos valores socialmente desejados. ${ }^{733}$ Em suma, a essência ética é o elemento diferenciador quanto aos tratamentos dispensados sobre a ilicitude do fato incidente sobre o "direito penal de justiça" e o "direito penal de mera ordenação".

Ocorre que Figueiredo Dias modificou seu entendimento sobre o tema, passando a entender que quanto aos "crimes de mera ordenação" o erro exerce a mesma função que em outros elementos do tipo objetivo, isto é, entre tais elementos e a proibição há uma relação que não admite distinção normativa e teleológica para a afirmação do dolo do tipo. ${ }^{734}$ Esse entendimento, é forçoso mencionar, traz sérias consequências quanto ao que se pretende de uma teoria analítica de crime posto que seria o mesmo que o reconhecimento de que a consciência da ilicitude pudesse ser parte do dolo, de modo que sua falta levaria à inexorável exclusão da tipicidade. E, para tal reconhecimento seria necessário interpretar a função do erro de proibição.

Assim, tomando a questão sobre o direito penal na sua essência mais clássica, o que se notava era o reflexo de valores primordiais na sociedade, não se tornando um fato crime apenas pela letra fria da lei, mas, antes disso, é vislumbrado como tal pela sociedade e apenas declarado pela norma. Assim já entendia Hungria, por exemplo, como ia além e discorria que "a experiência da vida social faz com que o homem normal, ainda que analfabeto ou jamais tenha lido um exemplar de código penal, saiba o que é reprovado pela ordem jurídica. Somente os loucos, os imaturos e o Homo sylvester ignoram o mínimo ético cuja transgressão constitui o ilícito penal". ${ }^{735}$ Em outras palavras, segundo Hungria, o

\footnotetext{
${ }^{733}$ DIAS, Jorge de Figueiredo. O problema da consciência da ilicitude em direito penal, cit., p. 393 e ss. ${ }^{734}$ Id. Direito penal: parte geral: questões fundamentais: a doutrina geral do crime, cit., p. 365.

${ }^{735}$ HUNGRIA, Nelson. op. cit., p. 120.
} 
homem estaria apto a reconhecer o que é lícito e ilícito pelos conhecimentos adquiridos ao longo da vida.

Exigindo-se, então, mero conhecimento leigo do ilícito para a caracterização da consciência da ilicitude, seria hercúlea a tarefa de alegar-se o desconhecimento sobre a proibição de matar ou roubar, por exemplo. Isto porque os bens atingidos e que se busca proteger nesses casos são essenciais, nucleares, estudados e entendidos como os de estima e respeito social, não perdendo sua importância e caráter, apesar das transformações socioculturais, estando profundamente inseridos num contexto em que todos sabem de sua proibição quanto à possibilidade de ofendê-los. E nesse mesmo diapasão, Jescheck já comentou que não sendo o fato unicamente uma infração da ordem jurídica, mas também uma violação da moral, o erro será, em regra, evitável porquanto a valoração jurídica advirá do sentimento jurídico, sendo reconhecível e sem grandes esforços da consciência, tendo-se em vista o bem jurídico atingido pela violação da norma. ${ }^{736}$

Segundo esse entendimento, então as condutas que contrariassem a ordem moral e social, além de ferir as normas jurídicas, tornariam o erro de proibição evitável porque, considerando-se a acentuada reprovação da conduta pelo meio social, seria possível conhecer o caráter ilícito do fato. Stratenwerth, nessa perspectiva, entende que, em geral, é possível ao autor ter acesso ao conhecimento do ilícito relativamente a normas penais que visam tutelar bens elementares, considerando improvável que alguém possa entender que tais violações pudessem ser ético-socialmente permitidas. ${ }^{737} \mathrm{E}$, então, pode-se mencionar Welzel, que já apontou que é justamente a cultura vivida que formará o conteúdo da consciência do ilícito, sendo certo que ao autor se poderá reprovar seu erro quando tinha a possibilidade de alcançar o caráter de ilicitude de seu agir pela reflexão dos valores éticosociais fundamentais. ${ }^{738} \mathrm{Ou}$ seja, com algum esforço de consciência poderia o autor alcançar o conhecimento de que sua atuação, especialmente porque o "critério da tensão da consciência ética só pode valer para o âmbito dos ilícitos moralmente fundados, só neles tendo sentido dirigir a censura à possibilidade de o agente ter alcançado uma reflexão axiológica". 739

\footnotetext{
${ }^{736}$ JESCHECK, Hans-Heinrich. Tratado de derecho penal: parte general. Trad. Santiago Mir Puig e Francisco Muñoz Conde. 3. ed. Barcelona: Bosch, 1981. p. 629.

${ }^{737}$ STRATENWERTH, Günther. Derecho penal: parte general: el hecho punible. 2. ed. Trad. Gladys Romero. Madrid: Edersa, 1982. v. 1, p. 186.

${ }^{738}$ WELZEL, Hans. Derecho penal alemán: parte general. Traducción de Juan Bustos Ramírez y Sergio Yáñez Pérez. 4. ed. Santiago de Chile: Editorial Jurídica de Chile, 1997. p. 203.

${ }^{739}$ DIAS, Jorge de Figueiredo. Direito penal: parte geral, cit., 2004, p. 581.
} 
Em se tratando, pois, de tipos penais cujas normas refiram-se a bens nucleares, o autor geralmente conhecerá a ilicitude do ato que pretende praticar, sendo-lhe possível a ponderação quanto desejado pelo ordenamento, abstendo-se da conduta. Todavia, quando mesmo assim decide pela atuação, mas alegando-se o desconhecimento da ilicitude, apenas excepcionalmente se falaria de exclusão da culpabilidade pelo possível atingimento da consciência da ilicitude pela verificação da ordem moral social.

Noutro sentido, sendo os bens jurídicos não nucleares, fica o agente mais suscetível de incidência em erro enquanto não perfeitamente arraigados e conscientizados tais bens como essenciais no âmbito social. Em tal situação não se verifica o mesmo sentimento de respeito que em outros casos, o que dificulta a consciência do ilícito de quem age contra tais bens. As informações e as formações morais, religiosas e todas as possíveis de se receber ao longo da vida podem, então, se mostrar insuficientes para, nesses casos, habilitar que o sujeito conheça a ilicitude, sendo-lhe possível diferenciá-la de situações outras, plenamente lícitas.

A questão acima mencionada só ocorre porque a conduta típica muitas vezes não se mostra reprovada pela ordem moral, violando-se apenas um mandado de tipo. Ou seja, são casos em que o comando proibitivo restará muito mais em situação de estar implícito no tipo penal porquanto fora editado pelo órgão competente e obedecido o processo legislativo que, propriamente, por seu conteúdo moral. Nesse sentido Welzel esclarece que tais normas não declaram passíveis de punição as ações e omissões que são merecedoras de pena sob a óptica da moralidade, mas pautam-se pela atividade administrativa do Estado, que preferiu criar modelo de proteção próprio. ${ }^{740}$

Uma questão de fundamental importância é que nem sempre o direito penal fará coincidir a norma jurídica com os postulados morais, não sendo raro que, por exemplo, por razões de política criminal, não se possa identificar de forma cristalina o que seja crime e o que seja uma infração moral. Não à toa Bitencourt já disse que a ação ilícita pode ser eventualmente louvável. ${ }^{741}$ Assim, pode-se afirmar que tradicionalmente o direito penal busca tipificar condutas relacionadas à ordem moral, de sorte que a conduta descrita no tipo não se mostra como contrária ao direito. Ocorre que, faltando a consciência da ilicitude, a norma não repercutirá na formação volitiva do sujeito, conduzindo-o à noção de

\footnotetext{
${ }^{740}$ WELZEL, Hans. Derecho penal alemán: parte general, cit., 4. ed., p. 203.

${ }^{741}$ BITENCOURT, Cezar Roberto. Erro de tipo e de proibição: uma análise comparativa. 2. ed. São Paulo: Saraiva, 2000. p. 82.
} 
que seu comportamento é lícito. Isto porque se relaciona o conhecimento da ilicitude como compreensão de valores ético-sociais, e porque muitas vezes os tipos penais que procuram defender bens jurídicos outros que não os tradicionais, então as pessoas perdem a noção quanto ao que seja atuação contrária ao direito.

Tal questão é fundamental ao se considerar que ao saber-se da ilicitude de suas condutas é que se poderá impor a alguém a reprovação de seu agir, porque se pressupõe a possibilidade que tenha trilhado, pela reflexão, caminho em que restava claro o que é ou não (i) lícito. Quanto mais se pensa em expansão do direito penal, ponderando-se igualmente o afastamento do ramo criminal como ultima ratio, torna-se razoavelmente mais complexa a compreensão da (suposta) congruência entre os valores morais e os tipos penais, dificultando e até mesmo impedindo que se determine de acordo com a norma. Nesse sentido já se mencionou que em face de um direito penal especial, o nível de exigência quanto ao dever de informação é incrementado para aqueles que devem submeter-se a essas normas. ${ }^{742} \mathrm{Na}$ medida em que a regulamentação se torna cada vez mais específica, mais complexo exigir das pessoas que conheçam certos níveis de proibição. Por outro lado, um agente que atue normalmente num setor específico de regulamentação teria sua censura quanto a uma determinada conduta que abranja sua habitual atuação mais dificultada. ${ }^{743}$

Diante do exposto, especialmente quanto a tipos penais que não dependem de resultado, mais precisamente os que tipificam perigo de lesão a certos bens jurídicos, por não serem comumente valorados como essenciais na mesma medida em que entendeu o legislador, é imprescindível que falte ao agente a consciência da proibição. Roxin já advertia que o erro de proibição não se mostra muito frequente no âmbito do direito penal nuclear, sendo mais comum quanto ao direito penal acessório. ${ }^{744}$ Há, no entanto, quem

\footnotetext{
${ }^{742}$ JESCHECK, Hans-Heinrich. Tratado de derecho penal: parte general, cit., 3.ed., p. 623.

${ }^{743}$ APELAÇÃO CRIMINAL № 2006.70.08.000212-6/PR. RELATOR Des. Federal MÁRCIO ANTÔNIO ROCHA.

APELANTE: MARCELINO DE BORBA NETO. ADV. (DT): Luiz Leandro Gaspar Dias. APELADO MINISTÉRIO PÚBLICO FEDERAL. EMENTA: PENAL. CRIME AMBIENTAL. MATERIALIDADE E AUTORIA COMPROVADAS. ERRO DE PROIBIÇÃO. INOCORRÊNCIA. Se o réu é pescador profissional que cotidianamente realiza atividades de pesca na mesma área, inobstante alegue ser pessoa humilde e de parcos recursos, não merece acolhimento a alegação de total desconhecimento de que pescava em área proibida, quando as circunstâncias do caso concreto demonstram que ele tinha consciência da ilicitude da conduta, o que afasta a hipótese de erro de tipo ou erro de proibição. ACÓRDÃO. Vistos e relatados estes autos em que são partes as acima indicadas, decide a Egrégia $7^{\mathrm{a}}$ Turma do Tribunal Regional Federal da $4^{\mathrm{a}}$ Região, por unanimidade, negar provimento à apelação, nos termos do relatório, votos e notas taquigráficas que ficam fazendo parte integrante do presente julgado. Porto Alegre, 11 de janeiro de 2011. Des. Federal MÁRCIO ANTÔNIO ROCHA Relator.

${ }^{744}$ ROXIN, Claus. Derecho penal: parte general, cit., 2. ed., p. 871.
} 
considere que, eventualmente, dado a grau de exposição nas diversas mídias, certos bens jurídicos especiais se mostram mais próximos da consciência que se pode ter dos bens nucleares. ${ }^{745}$ Todavia, somente analisando-se o caso concreto é que poderia o magistrado revestir-se de embasamento para enquadrar a situação como excepcional ou não. ${ }^{746}$

Seguindo essa linha de raciocínio e ponderando-se o direito penal sob a óptica do funcionalismo moderado, isto é, aquele em que se pode identificar bens jurídicos e, dentre eles fazer-se uma distinção entre os nucleares (mais relacionados a um caráter individual) e acessórios (mais relacionados à coletividade), cabe questionar se os bens jurídicos transindividuais integram a primeira ou a segunda espécie. Eis aqui um grande problema, haja vista que no atual cenário pátrio bens jurídicos como o meio ambiente, o sistema financeiro e o consumidor têm ganhado cada vez mais destaque, o que se verifica não só pelas intervenções legislativas, mas também pelas atuações do Ministério Público e da Polícia. Esse destaque, inicialmente, pode fazer sugerir que tais bens jurídicos integram o direito penal nuclear, que se presta a proteger interesses individualmente considerados das pessoas. Todavia, isso não torna tais interesses juridicamente tutelados mais presente na consciência social uma vez que, não estando imediatamente vinculados aos cidadãos, não há a mesma noção de que condutas relacionadas a violações a tais bens jurídicos sejam tão intensas como aquelas relativas a bens nucleares. Em outras palavras, até mesmo porque faz pouco tempo que se passou a ter reconhecimento jurídico mais significativo dos bens transindividuais, só a partir do século XX é que, ainda não estejam plenamente integrados no consciente social e, por isso, não são compreendidas como ilícitas com a intensidade tradicionalmente conferida a outras violações.

Ferrajoli já mencionou, quanto a isso, que se pode notar uma crise do Estado Social, isto é, a verificação de inflação legislativa, pela abstração das leis, maior incidência de normas penais em branco, entre outros. ${ }^{747}$ Obviamente esse panorama acaba por repercutir na consciência da ilicitude. Também Neuman já se posicionou sobre a atual situação expansiva do Direito Penal, particularmente verificável pela criação de tipos

\footnotetext{
${ }^{745}$ MOTTA, Ivan Martins. Erro de proibição e bem jurídico-penal. São Paulo: Ed. Revista dos Tribunais, 2009. p. 152. O autor exemplifica com a citação do art. 67 da Lei 8.078/90, que trata da propaganda enganosa. Menciona que dificilmente se poderia reconhecer a inevitabilidade do erro de proibição "invocado por um fabricante que fizesse propaganda enganosa ou abusiva ao consumidor". Adverte que isso não contraria a tese de que bens não nucleares tornam o erro de proibição mais frequente justamente porque se trata de uma exceção que confirma a regra. ${ }^{746}$ Id. Ibid.

${ }^{747}$ FERRAJOLI, Luigi. Derechos y garantias: la ley más débil. Trad. Perfecto Andrés Ibañez e Andréa Greppi. Madrid: Trotta, 1999. p. 15.
} 
penais, agravação das penas cominadas e incremento do estado policialesco. ${ }^{748}$ Ocorre que tal fenômeno - a expansão - não se mostra presente apenas e tão somente pelo surgimento de novas tipificações ou da consideração de que haja novos bens jurídicos. O Direito Penal passa a ser visto como um instrumento muito mais destinado a promover a segurança dos cidadãos do que violador de seus direitos e garantias fundamentais. ${ }^{749}$ Não à toa Silva Sanchez já discorreu sobre o sentimento de "insegurança" ${ }^{750}$ O próprio Neuman ponderou que "a compreensão do direito penal exclusivamente preventiva, instrumental, conduz à máxima de que tudo o que promete segurança é permitido". 751

No contexto acima mencionado não há como refutar que, havendo prevalência de bens jurídicos transindividuais e outras características da expansão, o direito penal mais atual se esteia em valores mais genéricos, com delimitação menos ou pouco precisa, e, com cada vez mais ingerência de agentes administrativos que detêm importante papel na limitação de ilícitos penais. Nesse particular, Hassemer lembra a frequente necessidade de autorizações advindas do Executivo quanto a matérias ambientais. ${ }^{752}$

As características vislumbradas a partir da expansão do Direito Penal contribuem, então, para a constante perda da consciência da ilicitude, incrementando o raio de alcance do erro de proibição, sendo maior a incidência do instituto quanto a condutas que expõem a perigo ou lesionam bens jurídicos transindividuais. Não só a eles, mas à própria segurança jurídica,

\subsection{Do erro de proibição e sua repercussão em algumas decisões judiciais no Brasil}

Tendo-se visto que o erro de proibição está intimamente relacionado com o conhecimento da ilicitude, e que este integra a culpabilidade num entendimento analítico (tripartido), trata-se, pois, de hipótese de exclusão da culpabilidade do agente, se invencível, ou, sendo vencível, hipótese de diminuição de pena. Representa o erro de proibição, desta forma, verdadeira falha na compreensão, por parte do agente, de que sua

\footnotetext{
${ }^{748}$ NEUMAN, Ulfrid. O princípio da proporcionalidade como princípio limitador da pena. Trad. Alfredo Martins. Revista Brasileira de Ciências Criminais, São Paulo, n. 71, p. 206, mar./abr. 2008.

${ }^{749}$ Id. Ibid., p. 207.

${ }^{750}$ SILVA SÁNCHEZ, Jesús-María. A expansão do direito penal: aspectos da política criminal nas sociedades pós-industriais, cit., p. 37 e ss.

${ }^{751}$ NEUMAN, Ulfrid. op. cit., p. 207.

${ }^{752}$ HASSEMER; Winfried. Persona, mundo y responsabilidad: bases para una teoria de la imputación en derecho penal, cit., p. 243.
} 
conduta insere-se no âmbito de proibição penal. Entende-se que tal situação demanda alguma demonstração por pesquisa de julgados a fim de apontar minimamente como os tribunais tem entendido a matéria em comento. Para tanto foram feitas pesquisas jurisprudenciais nos sítios da internet em diversos tribunais pátrios, como Tribunais de Justiça, Tribunais Regionais Federais, além do Superior Tribunal de Justiça e o Supremo Tribunal Federal. Neste ponto é importante apresentar as indexações feitas para pesquisa dos julgados:

"Conhecimento da ilicitude; Conhecimento e ilicitude; Consciência e ilicitude; Consciência da ilicitude; Erro e proibição; Erro de proibição; Conhecimento do injusto; Conhecimento e injusto.”

Importante consignar que mesmo com a busca por todos os termos acima não se obteve muitos resultados de julgados. Talvez até pelo maior movimento processual foi o Tribunal de Justiça do Estado de São Paulo o que apresentou maior número envolvendo questões relativas ao erro de proibição. Grande parte, no entanto, não admitiu a tese por entender que ela não estava comprovada pelos elementos existentes nos autos. São exemplos:

"O acusado admitiu os fatos, sem titubeios, alegando que desconhecia a ilicitude da conduta. Lá e cá. E inviável a escusa fundada na ausência de consciência da ilicitude com relação aos delitos praticados pelo acusado. Ora. A unia que "ignoranüa legis neminem excusat" Art 21, Cód.Pen. A duas que quem guarda grande quantidade de munição para arma de fogo em sua residência, sem se sujeitar ao procedimento da repartição pública responsável pela emissão do registro, sabe ou deve pelo menos saber da ilicitude daquela conduta. O fato é notório e é absolutamente impossivel crer que aqueles que vivem em cidades de grande porte, como aqui, organizadas e urbanizadas, desconheçam a situação. Reprise-se: não é possível, verossímil ou crivei que alguém que viva nos dias atuais desconheça questão tão comezinha, que é a necessidade de registro e autorização para o porte de arma e munição, seguindo-se os procedimentos de lei. Desconhecer esta regra mais que comezinha, repitase, será, "data venia", viver em mundo irreal, como nos tempos das cavernas". (Tribunal de Justiça do Estado de São Paulo - Apelação Criminal $\mathrm{n}^{\circ}$ 1.019.345.3/8, da Comarca de Campinas. Relator: Luis Soares de Mello. $4^{\text {a }}$ Câmara Criminal. Data do Julgamento: 16 de outubro de 2007). Neste caso julgava-se a posse irregular de munição de uso permitido e posse ilegal de munição de uso restrito (art. 12, e 16, "caput", lei $\left.\mathrm{n}^{\mathrm{o}} 10.826 / 2003\right)$.

"A autoria e a materialidade do crime em questão estão suficientemente provadas, com a nota de que o próprio acusado admitiu a compra das fitas, alegando, contudo, desconhecer a ilicitude da conduta. Essa circunstância, a meu aviso não provada, não pode ser considerada, pois o acusado sequer soube indicar nome ou endereço dos revendedores de quem comprava as fitas. $O$ réu, ainda que não fosse experimentado no 
ramo, tinha meios de saber da ilicitude." (Tribunal de Justiça do Estado de São Paulo - Apelação Criminal n ${ }^{\circ}$ 00946549.3/4-0000-000, da Comarca de Itapevi. Relator: Pinheiro Franco. $5^{\text {a }}$ Câmara Criminal. Data do Julgamento: 11 de janeiro de 2007). Neste caso apurava-se o delito de violação de direito autoral previsto no artigo $184, \S 2^{\circ}$, do Código Penal.

"A autoria é admitida pelo próprio réu. Entretanto, escorou sua defesa na tese de que não sabia que ilícita era sua conduta. O erro sobre a ilicitude do fato não restou demonstrado. Ao contrário do que alega, as receitas agronômicas emitidas em nome do réu (cf. fls. 91/95), são claras na recomendação quanto ao destino a ser dado às embalagens vazias: "enterrar em fosso sanitário seco ". Afora isso, não é crível que um produtor rural desconhecesse quais os cuidados mínimos necessários à manutenção de produtos agronomicos tóxicos, acreditando que pudesse deixá-los jogados no meio ambiente, esparramados em sua lavoura”. (Tribunal de Justiça do Estado de São Paulo - Apelação Criminal ${ }^{\circ}$ 412.809.3/2-00, da Comarca de Apiaí. Relator: Péricles Piza. $1^{\text {a }}$ Câmara Criminal. Data do Julgamento: 19 de dezembro 2005). Neste caso apurava-se delito ambiental.

"A alegação de desconhecimento da ihcitude do fato não merece acolhimento porque a prova dos autos demonstra que o réu adquiriu os CDs e DVDs piratas de forma consciente e voluntária, com o intuito de obter lucro, sendo certo que a pirataria de fonogramas é fato ilícito amplamente divulgado pelos meios de comunicação, havendo plena possibilidade de conhecimento da ihcitude do fato, o que configura a culpabilidade do acusado, não sendo caso de inocentá-lo como pretende a defesa, sob pena de tornar legítimo um comportamento amplamente combatido pelas entidades encarregadas de proteção dos direitos autorais". (Tribunal de Justiça do Estado de São Paulo - Apelação Criminal no 1187013 3-8, da Comarca de Leme. Relator: Lúcio Alberto Eneas da Silva Ferreira. $11^{\text {a }}$ Câmara Criminal. Data do Julgamento: 15 de agosto de 2008). Neste caso apurava-se o delito de violação de direito autoral previsto no artigo $184, \S 2^{\circ}$, do Código Penal.

Por outro lado, também há de se mencionar decisões que simplesmente foram fundamentados no argumento de que "não se pode admitir a alegação de erro sobre a ilicitude do fato criminoso, se o princípio fundamental é o de que 'o desconhecimento da lei é inescusável' (art. 21 do CP)". É o que se nota nos seguintes excertos:

"De outra parte, quanto ao alegado erro de proibição ou erro sobre a ilicitude do fato, adota-se o que consta no art. $3^{\circ}$ da Lei de Introdução ao Código Civil, que preceitua: "ninguém se escusa de cumprir a lei, alegando que não a conhece'. Tal princípio é perfeitamente justificável, proibindo que o sujeito apresente a própria ignorância como razão de não haver cumprido mandamento legal. Caso contrário, a força de eficácia da lei estaria irremediavelmente enfraquecida, comprometendo o ordenamento jurídico e causando danos aos cidadãos. In casu, era possivel aos réus a consciência da ilicitude da suas condutas, pois se tratando de moradores locais, eles tinham o dever de conhecer a restrição legal". (Tribunal de Justiça do Estado de São Paulo. Apelação Criminal $\mathrm{n}^{\circ}$ 990.09.221124-2. Relator: Eduardo Braga. Data do julgamento: 21.10.10). Nestes autos discutia-se a pesca proibida, em 
desacordo com o disposto na Portaria do IBAMA n. 9/03, c.c. artigo ls, inciso I, da Lei Federal n. 7679/88 - Infração ao artigo 34, parágrafo único, inciso III , da Lei n. 9.605/98.

"Com efeito, o delito referente à arma de fogo apresenta-se caracterizado, não se acolhendo a tese de desconhecimento da ilicitude da conduta sub judice, pois que conforme preceitua o art. 21, caput, do Código Penal, o desconhecimento da lei é inescusável." (Tribunal de Justiça do Estado de São Paulo - Apelação Criminal no 299.113-3/4-00. Relator: Canellas de Godoy. Data do julgamento: 23.05.00). Aqui se apurava crimes previstos nos arts. 307, do Código Penal e art. 10, § 2o, da Lei $\mathrm{n}^{\circ}$ 9.437/97, ambos combinados com o art. 69, do Código Penal.

"Com efeito, o delito referente à arma de fogo apresenta-se caracterizado, não se acolhendo a tese de desconhecimento da ilicitude da conduta sub judice, pois que conforme preceitua o art. 21, caput, do Código Penal, o desconhecimento da lei é inescusável". (Tribunal de Justiça do Estado de São Paulo. Apelação Criminal n 299.113-3/4-00, da Comarca de Sumaré. Relator Canellas de Godoy. Julgamento em 23 de maio de 2000).

"E nem se alegue desconhecimento da lei ou da ilicitude do fato. "Ignorantia legis neminem excusat". Desde logo se diga. Como do art. 21, "caput' do Cod. Penal e o art. $3^{o}$ da Lei de Introdução do Código Civil". (Tribunal de Justiça do Estado de São Paulo. Apelação Criminal $n^{\circ} n^{\circ} 492.614$, da Comarca de Guaíra. Relator Luis Soares de Mello. Julgamento em 14 de fevereiro de 2006)

Noutros casos, por exemplo, alegou-se a notoriedade do bem jurídico tutelado para que se afastasse o erro deproibição. Veja-se:

"A tese do erro de proibição também não merece acolhida, já que a necessidade da proteção do meio ambiente é fato notório, amplamente divulgado pelos meios de comunicação e que faz parte do currículo escolar. Além disso, a ninguém é dado alegar o desconhecimento da lei como forma de afastamento da responsabilidade penal, mormente em provindo o alegado desconhecimento de erro inescusável e que não apenas poderia como deveria ser evitado. Ressalto que o réu ainda não poderia ser considerado ingênuo, haja vista que já condenado por porte de arma além de responder, preso, pelo crime de produção e tráfico ilícito de entorpecentes (certidão de antecedentes de fls. 17/19)". (Turma Recursal Criminal dos Juizados Especiais Criminais do Estado do Rio Grande do Sul. Recurso Criminal $\mathrm{n}^{\mathrm{o}}$ 71003476256, da Comarca de Jacarezinho. Relatora: Cristina Pereira Gonzales. Data do Julgamento: 27 de fevereiro de 2012).

"1 - Tendo em vista a ampla divulgação, pelos meios de comunicação, acerca da relevância da proteção ambiental, é de ser afastada a alegação de erro de proibição. 2 - O princípio da insignificância não se coaduna aos crimes ambientais, pois a lesão ao meio ambiente é cumulativa e perceptível somente a longo prazo". (Tribunal de Justiça do Rio Grande do Sul. Apelação Criminaç no 70022235444 . Relator: Gaspar Marques Batista. $4^{\mathrm{a}}$ Câmara Criminal. Data do julgamento: 1 de março de 2008. 
Em outro julgado verifica-se que o conhecimento de que uma conduta constituía infração administrativa foi suficiente para que se afastasse o erro sobre a ilicitude, atribuindo ao agente a responsabilidade por dolo. Veja-se:

\begin{abstract}
"A condenação é de rigor, tendo em vista a existência de dolo. Segundo o próprio apelado, em seu interrogatório, "não sabia que o que estava fazendo poderia configurar crime, pois acredita que se tratava, no máximo, de uma infração de trânsito." Tal declaração demonstra que na sua intima intenção, o apelado sabia que o ato praticado por ele era ilegal, mesmo que somente administrativamente. O apelado disse em seu interrogatório que tem o terceiro grau incompleto e, como bem exposto pela promotora, "não se pode cogitar de ocorrência de erro quanto ao tipo" tendo em vista que ele não é pessoal leiga. Não podemos dizer que o erro foi sobre o elemento do tipo, pois não houve um equivoco sobre o fato descrito na lei penal como crime. No entanto, alegou a defesa, a existência do desconhecimento da lei. Com relação a isso, o artigo 21, do Código Penal descreve que "o desconhecimento da lei é inescusável". Segundo a doutrina, "se de um lado ninguém pode ignorar a existência formal da lei, pode faltar ao sujeito o potencial conhecimento da proibição contida, levando-o a atuar com o desconhecimento do injusto.1" O Código Penal brasileiro permite, nesses casos, isentar-se de pena ou diminuí-la. No entanto, no fato em questão, o apelado poderia evitar a prática de tal crime, em razão de lhe ser possível alcançar o conhecimento da ilicitude de sua conduta". (Tribunal de Justiça do Estado de São Paulo. Apelação Criminal no 990.09.030674-2. Relator: Ruy Alberto Leme Cavalheiro. Data do julgamento: 30.07.09).
\end{abstract}

Nota-se, portanto, que o fato do agente ter ensino superior, ainda que incompleto, serviu de base para que fosse afastado o erro, entendendo-se que o agente não era leigo. Também fundamentou a decisão ter o agente admitido que sabia que sua conduta configurava infração administrativa. Mesmo assim, sua pena foi reduzida de metade, de acordo com o que dispõe o art. 21, Código Penal. O crime a ele atribuído era o do art. 311, Código Penal (adulteração de sinal identificador de veículo automotor).

Inobstante, há julgados que reconhecem o instituto do erro de proibição. Seguem exemplos:

"1. Com razão as ponderações feitas pelo o d. Ministério Público Federal, quando opinou pelo provimento do recurso, ao argumento de que "O réu desconhecia a irregularidade da situação, pois, trabalhava de forma subordinada para o proprietário da draga, o Sr. Edvaldo Teixeira Cavalcante, este deveria regularizar e obter a devida autorização" (fl. 188). 2. O erro de proibição incide sobre a consciência da ilicitude do fato e para sua configuração, é necessário que o agente não tenha consciência sobre ser proibida a sua conduta, acreditando que se encontra agindo de boa-fé, dentro da normalidade. 3. Merece acolhida a tese de que o ora apelante, como subordinado do proprietário da draga, está desobrigado de conhecer sobre a situação irregular, seja 
do proprietário da draga em relação à Cooperativa dos Garimpeiros, Mineração e Agroflorestas - MINACOOP, seja quanto ao prazo de validade da licença de operação expedida pelo órgão ambiental à referida Cooperativa. 4. Sentença reformada. 5. Apelação provida". (Tribunal Regional Federal da $1^{\text {a }}$ Região. Apelação Criminal no $0009800-$ 57.2010.4.01.4100/RO. Relator: I'talo Fioravanti Sabo Mendes. $4^{\mathrm{a}}$ Turma. Data do julgasmento: 14 de outubro de 2011).

"1. A conduta atribuída à ora apelante configura o tipo penal descrito no art. 183, da Lei $n$. 9.472/97, tendo em vista que o "Desenvolver clandestinamente atividades de telecomunicação", sem a devida autorização do órgão competente, consubstancia crime formal, que independe de resultado danoso para configuração do delito. 2. A conduta prevista no art. 183, da Lei $n^{\circ}$ 9.472/97, consistente em "Desenvolver clandestinamente atividades de telecomunicação", sem a devida autorização do órgão competente, consubstancia crime formal, que independe de resultado danoso para configuração do delito. 3. O tipo penal descrito no art. 183, da Lei $n^{\circ} 9.472 / 97$ se consuma no momento em que realizada a conduta prevista, qual seja, a de desenvolver atividade de telecomunicações sem autorização do órgão competente, para tanto, nada havendo a norma legal tratado acerca da potencialidade lesiva do equipamento, circunstância que faz com que não mereça acolhida eventual entendimento no sentido de se aplicar, no caso, $o$ princípio da insignificância. 4. No caso dos autos, tanto a materialidade quanto à autoria, restaram comprovadas, na forma em que demonstrou a v. sentença apelada. 5. Na hipótese dos autos, é de se reconhecer a ocorrência in casu de erro de proibição quanto ao uso do aparelho telefônico sem fio de longo alcance. Com efeito, o art. 21 do Código Penal prescreve que o desconhecimento da lei é inescusável. Todavia, não se pode confundir o desconhecimento da lei, que é inescusável, com o erro de proibição que se encontra previsto na segunda parte do art. 21, do Código Penal, que não necessariamente decorre do desconhecimento da lei. 6. O erro de proibição incide sobre a consciência da ilicitude, que pode ser entendido como um juízo emitido de acordo com a opinião comum dominante no meio social, fazendo com que o agente suponha ser a sua conduta permitida pelo ordenamento jurídico. Assim, quando o agente não tem consciência sobre ser proibida a sua conduta, acreditando que se encontra agindo de boa-fé, dentro da normalidade, é de se reconhecer a ocorrência do erro de proibição. 7 . $\mathrm{Na}$ hipótese, data venia de eventual entendimento em contrário, verificase que o contexto dos fatos está a demonstrar que a ré não tinha ciência da necessidade de autorização da ANATEL para colocar em funcionamento o equipamento de telefone sem fio de longo alcance. 8. Desconhecendo a ora apelante a necessidade de autorização estatal para funcionamento do equipamento por ela adquirido, é de se reconhecer o erro de proibição, pois é de se entender como presente, no caso em comento, a sua falsa convicção da licitude da conduta por ela praticada. Assim, havendo ocorrido in casu o erro de proibição inevitável, tem aplicação à hipótese o disposto no art. 21, caput, do Código Penal, segundo o qual o erro de proibição inevitável isenta o agente de pena. 9. Sentença reformada. 10. Apelação provida". (Tribunal Regional Federal da $1^{a}$ Região. Apelação Criminal 0008438-72.2008.4.01.3200/AM. Relator: I'talo Fioravanti Sabo Mendes. $4^{\mathrm{a}}$ Turma. Data do julgasmento: 11 de março de 2011. 
Num dos casos, embora reconhecido o "evidente erro sobre a ilicitude do fato", a decisão absolutória adveio em razão da prescrição retroativa. Todavia fez-se questão de consignar no acórdão o seguinte:

"Recurso de Apelação interposto (...), com razões às fls. 147, alegando desconhecimento pelo réu da ilicitude praticada face a sua avançada idade. Evidente o erro sobre a ilicitude do fato". (Tribunal de Justiça do Estado de São Paulo. Apelação Criminal $\mathrm{n}^{\circ}$ 269.783-3/6-00. Relator: Barbosa Pereira. Data do julgamento: 08.03.01).

Aqui a idade do agente teria sido determinante, não fosse a prescrição, para o reconhecimento da inexistência do conhecimento da ilicitude.

Noutro caso verifica-se a questão de cultura arraigada em sociedade, que pode influenciar no conhecimento da ilicitude, conforme se observa no seguinte excerto:

"Contudo, não se pode esquecer que o erro sobre a ilicitude do fato, se inevitável, isenta a pena, e se evitavel, determina a redução da reprimenda de um sexto a um terço. Em face do costume arraigado na cidade, os acusados não tinham a consciência sobre a ilicitude do fato. Como sempre foram usados serviços e funcionários da prefeitura para pequenos reparos em imóveis particulares, achavam que não estavam cometendo nenhum ilícito penal. $O$ erro sobre a ilicitude do fato, em relação aos acusados, era inevitável. Dadas as circunstâncias como os fatos ocorreram, não tinham como atingir o conhecimento que estavam cometendo um ilícito penal. A prática reiterada do uso de serviços e funcionários da prefeitura durante anos seguidos, através de vários mandatos de prefeitos eleitos por partidos diversos, impedia que os acusados atingissem a consciência que estavam cometendo um ilícito penal. O erro sobre a ilicitude do fato era, na hipótese, inevitável e, assim, não há como aplicar a pena aos recorrentes pela violação do artigo 1o, inciso II, do Dec. Lei $n^{\circ}$ 201/67'. (Tribunal de Justiça do Estado de São Paulo Embargos de declaração no 856.595.3/4-01. Relator: Almeida Braga. Data do julgamento: 15.01.07).

Neste caso a reiteração de condutas ilícitas tidas como não violadoras da lei, ao longo do tempo, foi o argumento para que fosse afastado o conhecimento da ilicitude.

No âmbito do Superior Tribunal de Justiça pode-se verificar que grande parte dos julgados obtidos com a indexação retro mencionada eram no sentido da impossibilidade de análise de provas tendo-se em vista que os autos referiam-se a habeas corpus, portanto esfera inadequada para discussão da matéria. Veja-se, por exemplo:

"I. Análise das alegações concernentes ao pleito de absolvição do réu e de ocorrência de erro de proibição que demandaria o revolvimento do conjunto fático-probatório, inviável em sede de habeas corpus. 
II. A via estreita do writ é incompatível com a investigação probatória, nos termos da previsão constitucional que o institucionalizou como meio próprio à preservação do direito de locomoção, quando demonstrada ofensa ou ameaça decorrente de ilegalidade ou abuso de poder (art. $5^{\circ}$, inciso LXVIII)." (Habeas Corpus n ${ }^{\circ}$ 190.568/DF. Relator Ministro Gilson Dipp. $5^{\text {a }}$ Turma. Data do julgamento: 14 de abril de 2011).

Já no Supremo Tribunal Federal foram encontrados dois resultados. No primeiro caso, tem-se Inquérito datado de antes da promulgação da Constituição Federal de 1988, e que reconheceu a tese do erro de proibição, arquivando-se os autos, conforme se verifica abaixo:

\begin{abstract}
"Versam os presentes autos investigações tendentes a definir o grau de responsabilidade do Deputado Federal Santinho Furtado ao determinar a execução de propaganda eleitoral em desacordo com a legislação eleitoral, na cidade de Jacarezinho, Paraná. A propaganda se restringe à colocação de cartazes com a foto do candidato elou a pintura do nome "Santinho" em postes de iluminação, especialmente nas avenidas Manuel Ribas e Getúlio Vargas. (vide fls. 9 e 10). No depoimento às fls. 42, o Deputado Federak santinho Furtado deixa claro, verbis: "em data que não se recorda, determinou a sua equipe de pintores que fossem até a cidade de Jacarezinho, onde deveriam fazer algumas colagens, e, inclusive pinturas em muros, pois não entendia estar fora do que estabelece a lei; que determinou estas medidas, pois, na própria capital do Estado, em frente ao Tribunal Eleitoral, as propagandas estavam em todos os locais, inclusive nos postes; que após ser comunicado a proibição de tais propagandas, isto é, do meio utilizado, determinou, através dos mesmos que a haviam feito, que voltassem aos referidos locais e retirassem os cartazes, bem como nos muros fizessem novas pinturas, para cumprir a determinado na lei eleitoral". Como se vê, Santinho Furtado entendeu por normal e permitido tal tipo de propaganda, pois, todos os demais candidatos dela se valiam; contudo, ao tomar ciência da irregularidade das mesmas, de pronto determinou que fossem suprimidas. Em face disso entendemos não carcacterizada motivação delituosa no seu pautar-se. Pelo arquivamento dos autos." (Supremo Tribunal Fedral. Inquérito $\mathrm{n}^{\circ}$ 352-2. Relator: Carlos Madeira. Data do julgamento: 03 de dezembro de 1987).
\end{abstract}

No segundo caso, verificou-se, curiosamente, mais um Inquérito envolvendo questões eleitorais. ${ }^{753}$ Veja-se:

"INQUÉRITO. DENÚNCIA. ART. 350 DO CÓDIGO ELEITORAL. DENUNCIADO QUE SUBSCREVEU NOVA PRESTAÇÃO DE CONTAS EM SUBSTITUIÇÃO A DOCUMENTO ANTERIORMENTE APRESENTADO PERANTE A JUSTIÇA ELEITORAL, AO INVÉS DE PROVIDENCIAR SUA RETIFICAÇÃO. AUSÊNCIA DE DOLO. ATIPICIDADE RECONHECIDA. ERRO DE PROIBIÇÃO

\footnotetext{
${ }^{753}$ Sobre o tema, veja-se: PONTE, Antonio Carlos da. Crimes eleitorais. São Paulo: Saraiva, 2008.
} 
IGUALMENTE VERIFICADO. AUSÊNCIA DE JUSTA CAUSA. DENÚNCIA REJEITADA. 1. Para que ocorra o crime, o sujeito ativo deve estar consciente de que está praticando o falso ideológico, segundo a descrição da norma. O elemento subjetivo está na intenção livre de falsificar, com perfeita noção da reprovabilidade do ato. 2. Interpretou o denunciado a norma proibitiva que concerne diretamente ao fato, tomando seu comportamento como permitido e aprovado pelo Direito, em evidente ocorrência de erro de proibição $(C P$, art. 21). 3. Denúncia rejeitada". (Inquérito n ${ }^{\circ} 2559$ / MG - Minas Gerais. Relator Dias Toffoli. Tribunal Pleno. Data do julgamento: 18 de agosto de 2011).

Eis, então, a apresentação de alguns julgados que pretenderam ilustrar o tratamento do erro de proibição pelos Tribunais pátrios.

\subsection{As teorias do dolo e da culpabilidade no contexto das normas penais em branco e a questão do erro}

A regra geral aponta no sentido de que o erro sobre as circunstâncias fáticas exclui o dolo, possibilitando a atribuição de responsabilidade penal por culpa (quando o crime praticado comportar tal modalidade) ou mesmo a impunidade (quando não houve a previsão da culpa para o tipo penal). A grande questão resvala nos casos em que o erro do autor incide sobre o significado jurídico das normas extrapenais. Neste caso também se exclui o dolo ou este restará intacto?

O dolo e o erro constituem duas faces da mesma moeda, pelo que a exclusão do elemento subjetivo relaciona-se de forma muito próxima com o conceito de dolo que se pretenda manejar. E a definição de dolo não é algo que se verifique em legislações como a espanhola e a alemã, apesar de que, no Brasil, exista definição de crime doloso no art. 18 do Código Penal. ${ }^{754}$

Então, normalmente se distingue o erro de tipo do erro de proibição da seguinte forma: o primeiro é o que recai sobre os elementos do tipo de injusto ao passo que o segundo é o que incide sobre o significado de ilicitude da conduta, uma vez conhecidos os

\footnotetext{
${ }^{754}$ Art. 18. Diz-se o crime: Crime doloso. I - doloso, quando o agente quis o resultado ou assumiu o risco de produzi-lo.
} 
elementos típicos. ${ }^{755}$ Ocorre que a mencionada diferenciação traz à tona duas teorias que pretendem auxiliar na efetiva distinção. Trata-se das teorias do dolo e da culpabilidade.

A teoria do dolo parte de uma concepção de dolus malus, abrangendo a totalidade do aspecto subjetivo do fato e sendo passível de análise no âmbito da culpabilidade. O dolo identifica-se, neste caso, não só com o conhecimento dos elementos do tipo, mas também da ilicitude da conduta de modo que o erro incidente sobre quaisquer destes receberia o mesmo tratamento jurídico-penal, isto é, a não aplicação da pena pela prática de crime doloso, atribuindo-se ao agente a pena correspondente ao crime culposo (ou mesmo verificando-se a impunidade). ${ }^{756}$

As mudanças ocorridas na interpretação da teoria do delito, deixando-se para trás uma concepção objetiva do injusto para aceitação de concepção pessoal, resultou em importantes consequências para a teoria do erro, isto é, a passagem do dolo para o tipo penal - inovação trazida pelo Finalismo - fez com que as representações imbuídas de erro também tivessem influência neste âmbito (do tipo penal).

É justamente neste contexto que se desenvolveu a teoria da culpabilidade, operando um conceito de dolo natural, separando-se o dolo (no tipo penal) e a consciência da ilicitude como elemento da culpabilidade. Assim, a ideia subjacente é que o conhecimento da realização típica constituiria um nível prévio ao conhecimento da ilicitude e, com ele, da plena culpabilidade. ${ }^{757} \mathrm{O}$ tratamento penal menos favorável ao autor que erra sobre a proibição teria origem na "função de chamada do dolo". 758

As repercussões práticas da separação acima mencionada são mais facilmente verificáveis nos ordenamentos em que a culpa mostra-se preponderantemente uma espécie subsidiária de criminalidade, isto é, nos casos em que os tipos penais não prevejam modalidade culposa haveria impunidade quando alguém atuasse mediante erro. Isto significa que a verificação de um fato típico e ilícito condicionaria a imposição de medida de segurança aos inimputáveis que atuassem mediante erro de tipo vencível. Por outro

\footnotetext{
${ }^{755}$ Art. 14, Código Penal Espanhol e $§ § 16$ e 17 do Código Penal Alemão (StGB).

${ }^{756}$ RODRÍGUEZ MOURULLO, Gonzalo. Derecho penal: parte general. Madrid: Civitas, 1978. Cap. XIII; TORÍO LÓPEZ, Ángel. El "error iuris", perspectivas materiales y sistemáticas. Anuário de Derecho Penal y Ciencias Penales, ADPCP, Madrid, p. 38, 1975, p. 38, entre otros. en los últimos tiempos COBO DEL ROSAL, Manuel; VIVES ANTÓN, Tomá S. Derecho penal: parte general. 5. ed. Valencia: Tirant lo Blanch, 1999. p. 619.

${ }^{757}$ FAKHOURI GÓMEZ, Yamila. Teoría del dolo vs. teoría de la culpabilidad: un modelo para afrontar la problemática del error en derecho penal. InDret: revista para análisis del derecho, Barcelona, n. 4, p. 7 , 2009.

${ }^{758}$ Id., loc. cit.
} 
lado, o nível de consciência exigido ao autor seria diferente: no âmbito do tipo se exige o conhecimento dos elementos que o compõem ao passo que no âmbito da culpabilidade bastaria que o autor pudesse conhecer a proibição para que se afirmasse o dolo.

Particularmente quanto à teoria da culpabilidade, a evolução verificada na teoria do delito não promoveu redução das questões polêmicas, chegando-se a afirmar que estas até aumentaram. ${ }^{759}$ É que no sistema clássico e neoclássico do delito a questão limitava-se a determinar quais erros excluiriam o dolo e quais os requisitos para que isso ocorresse. Ocorre que o deslocamento do dolo para o tipo e o consequente desenvolvimento da teoria da culpabilidade resultaram na necessidade de se estabelecer a localização sistemática do erro: estaria no nível do injusto ou da culpabilidade? Sob outra perspectiva, nem tudo mudou completamente, havendo quem aloque o dolo na culpabilidade. ${ }^{760}$ Há, ainda, quem reconheça a importância do dolo no tipo de injusto, considerando que o erro resultaria compatível com os postulados da teoria do dolo. ${ }^{761}$

Os efeitos de ordem prática que tal classificação proporciona fazem com que reflexões alheias à questão do erro exerçam certa influência nas discussões sobre a matéria. ${ }^{762}$ Some-se o fato de que existem importantes divergências sobre se a falsa representação insere-se num ou noutro contexto de erro. O consenso, neste ponto, se reduz aos exemplos tradicionalmente apontados nos manuais: é erro de tipo aquele que incide sobre o caráter alheio da coisa ou sobre a condição de documento sobre algo que se falsifica. Por outro lado, relativamente ao erro de proibição importa verificar o caráter ilícito da conduta ou de contrariedade ao direito.

A forma pela qual a delimitação acima referida é feita concretamente aponta no sentido de que a prática difere da teoria. Isto porque quando se pretende distinguir o erro de tipo do de proibição os obstáculos mostram-se agrupados em diferentes níveis, relacionando-se, em primeiro lugar, com elementos formadores do tipo penal, e depois, com a falta de fundamento para exigir pontos de referência diferentes para o dolo relativamente às distintas remissões normativas. Em terceiro lugar, pela falta de critérios

\footnotetext{
${ }^{759}$ FAKHOURI GÓMEZ, Yamila. op. cit., p. 7.

${ }^{760}$ TORÍO LÓPEZ, Ángel. op. cit., p. 38, entre otros. En los últimos tiempos COBO DEL ROSAL, Manuel; VIVES ANTÓN, Tomá S. Derecho penal: parte general. 5. ed., cit., p. 619.

${ }^{761}$ MIR PUIG, Santiago. Derecho penal: parte general, cit., 8. ed., Lecc. 21 , no 24 e ss., 40 e ss.

${ }^{762}$ FAKHOURI GÓMEZ, Yamila. op. cit., p. 8.
} 
para determinar o objeto do dolo e, por fim, porque há impossibilidade de se chegar a uma verdadeira delimitação entre o erro de tipo e o de proibição na maioria dos casos. ${ }^{763}$

Considerando-se a teoria da culpabilidade, a inclusão de uma remissão normativa concreta na categoria de elemento normativo ou de tipo penal em branco condiciona aquilo que deve ser conhecido pelo autor para fixar sua responsabilidade a título de dolo. Assim, o elemento normativo constituiria um elemento típico que, conforme indica a teoria da culpabilidade, deveria ser conhecido pelo autor ao atuar dolosamente. $\mathrm{O}$ desconhecimento da norma de complemento constituiria, então, um erro de tipo (excluindo o dolo). A verificação do dolo do autor se nota pela compreensão do significado social do fato, isto é, não é suficiente o simples conhecimento dos fatos e tampouco uma subsunção exata aos termos legais. Bastaria que se tivesse produzido uma valoração paralela na esfera do profano ou um juízo paralelo na consciência do autor. ${ }^{764}$

Quanto às normas penais em branco, o conhecimento do tipo dependeria da leitura conjunta dos elementos ora separados de maneira a formar um tipo único. O elemento em branco deveria ser substituído pelo conteúdo da norma de remissão. Ao tipo penal em branco complementado desta forma resultaria a aplicação de critérios gerais em matéria de dolo e erro. Ou seja, o dolo deveria abranger circunstâncias do fato. O desconhecimento sobre a existência da norma de complemento receberia, então, o tratamento do erro de proibição. $^{765}$

O fato é que a decisão de o legislador criar tipos penais que dependam ou independam de outras normas para serem aplicados não representa uma base adequada para a construção teórico-dogmática do erro. A norma penal em branco permitiria a inclusão de um grande número de requisitos de fato no tipo e possibilitaria uma rápida adaptação da lei ao passo que o elemento normativo contribuiria para evitar formulações

\footnotetext{
${ }^{763}$ FAKHOURI GÓMEZ, Yamila. op. cit., p. 9.

${ }^{764}$ Id. Delimitación entre error de tipo y de prohibición: las remisiones normativas: un caso problemático. Navarra: Civitas, 2009. §5. III.A.

${ }^{765}$ Neste sentido: ARIAS EIBE, José Manuel. El error en derecho penal en el Código de 1995. Madrid: Dykinson, 2007. p. 97. Vide, também, FAKHOURI GÓMEZ, Yamila. Teoría del dolo vs. teoría de la culpabilidad: un modelo para afrontar la problemática del error en derecho penal, cit. Esta autora traz em seu artigo uma série de referências que afirma adotarem este mesmo posicionamento. São eles: WARDA, Die Abgrenzung von Tatbestands - und Verbotsirrtumbei Blankettstrafgesetzen, 1955, p. 27 y ss., 31, 36, 38 y ss., que introduce numerosos ejemplos. En este sentido también BACHMANN, Vorsatzund Rechtsirrtum (...), 1993, pp. 26, 69 y ss.; CRAMER/STERNBERG-LIEBEN, en SCHÖNKE/SCHRÖDER (eds.), Strafgesetzbuch Kommentar, $27^{\mathrm{a}}$ ed., 2006, § 15, mn. 100 y s.; JESCHECK/WEIGEND, Lehrbuchdes Strafrechts. Allgemeiner Teil, $5^{\mathrm{a}}$ ed., 1996, § 29.V.3; MAURACH/ZIPF, Strafrecht Allgemeiner Teil 1. Grundlehren des Strafrechts und Aufbau der Straftat. Ein Lehrbuch, $8^{a}$ ed., 1992, § 23, nm. 9; MEZGER, Lehrbuch (...), $3^{\text {a }}$ ed., 1949, § 24. IIII.1; RUDOLPHI, en RUDOLPHI et al. (eds.), SK, t. I, $7^{\text {a }}$ ed., § 16, nm. 18 y s.; SCHRÖDER, F. C., en JÄHNKE et al. (eds.), LK, $11^{\text {a }}$ ed., 1994, § 16, nm. 39.
} 
casuísticas dos tipos penais. Assim, a opção por determinada técnica legislativa não parece responder a uma valoração do legislador que deveria encontrar seu reflexo na culpabilidade do autor. ${ }^{766}$

Por outro lado, houve críticas sobre a ideia de leitura conjunta da norma penal e da norma complementadora para a obtenção de um tipo penal único, porquanto a substituição dos conceitos extrapenais por conceitos descritivos não modificaria a aplicação da norma. ${ }^{767}$ Desta forma, reconhecido que não sendo mera modificação de caráter técnico, a substituição do elemento típico pela norma de complemento anularia o componente normativo do primeiro, não havendo motivos para propugnar um objeto do dolo diferente daquele relativo ao elemento normativo e da norma penal em branco. ${ }^{768}$

Pois bem, com base na teoria da culpabilidade, parte-se da ideia de que ela teria aplicação geral em face do ordenamento, o que fez parcela da doutrina se afastar dos postulados referentes ao direito penal acessório. Assim, alguns autores propugnam pela aplicação da teoria do dolo aos erros de proibição incidentes sobre as normas pertencentes a este âmbito de regulação. Isto porque estas normas distanciar-se-iam da moral que goza de reconhecimento social, e a informação de que o autor dispõe a partir das circunstâncias de fato não resultaria suficiente para motivá-lo a omitir sua conduta. ${ }^{769}$ Por outro lado, outros autores emprestam ampla margem de aplicação à inevitabilidade do erro de proibição, chegando-se ao extremo de entenderem-se sempre inevitáveis. ${ }^{770}$

\footnotetext{
${ }^{766}$ DOVAL PAÍS, Antonio. Posibilidades y límites para la formulación de las normas penales: el caso de las leyes en Blanco. Valencia: Tirant lo Blanch; Universitat de Valéncia, 1999. p. 87.

${ }^{767}$ DÍAZ Y GARCÍA CONLLEDO, Miguel. El error sobre elementos normativos del tipo penal. Madrid: La Ley, 2008. p. 341.

${ }^{768}$ FAKHOURI GÓMEZ, Yamila. Teoría del dolo vs. teoría de la culpabilidad: un modelo para afrontar la problemática del error en derecho penal, cit., p. 12.

${ }^{769}$ TORÍO LÓPEZ, Ángel. El error evitable de prohibición en el Proyecto de Código Penal. Indicaciones de política legislativa sobre la «Teoría de la culpabilidad». In: LA REFORMA penal y penitenciaria (Cursos y congresos de la Universidad de Santiago de Compostela). Santiago de Compostela: Universidad, 1980. p. 256 y ss.

${ }^{770}$ BAJO FERNÁNDEZ, Miguel; SUÁREZ GONZÁLEZ, Carlos; PÉREZ MANZANO, Mercedes (Eds.). Manual de derecho penal: parte especial. Delitos patrimoniales y econômicos. 2. ed. Madrid: Centro de Estudios Ramón Areces, 1993. p. 586; CEREZO MIR, José. La regulación del error de prohibición en el Código penal español y su trascendencia en los delitos monetarios. Anuário de Derecho Penal y Ciencias Penales, ADPCP, Madrid, p. 284, 1985; NIETO MARTÍN, Adán. El conocimiento del derecho: un estudio sobre la vencibilidad del error de prohibición. Barcelona: Atelier, 1999; DÍAZ Y GARCÍA CONLLEDO, Miguel. El error de prohibición: pasado, presente y futuro. In: CEREZO MIR, J.; SUÁREZ MONTES, R. E.; BERISTAIN IPIÑA, A.; ROMEO CASABONA, C. M. (Eds.). El nuevo Código Penal: presupuestos y fundamentos. Libro Homenaje al Profesor Ángel Torío López. Granada: Comares, 1999. p. 359; OLAIZOLA NOGALES, Inés. El error de prohibición: especial atención a los criterios para su apreciación y para la determinación de su vencibilidad e invencibilidad. Madrid: La Ley, 2007. p. 138, 140.
} 
Fato é que os erros de tipo e de proibição nem sempre podem ser diferenciados com base na teoria da culpabilidade. Veja-se que relativamente aos elementos normativos restaria bastante difícil distinguir a valoração paralela exigida para a afirmação do dolo e a valoração que se identifica com o conhecimento do caráter ilícito da conduta. Neste sentido, a redução do objeto do dolo aos fatos suporia um retorno à vetusta distinção entre os erros de fato e de direito, ao passo que outro setor doutrinário passa a reconhecer o efeito excludente do dolo ao erro incidente nas normas extrapenais. ${ }^{771}$

Apesar disso, tentaram-se outros caminhos como os que supunham uma redução do objeto do dolo ou redefinição do critério da valoração paralela, de modo que a consciência de que se viola um bem jurídico seria suficiente para a verificação do dolo $;^{772}$ também que o dolo se define com o conhecimento das circunstâncias que compõem o injusto. ${ }^{773}$

A dificuldade em delimitar o elemento normativo e a norma penal em branco, somada à reflexão cada vez mais presente de que ela não seria determinante para definição do objeto do dolo, levou à aplicação destes critérios para delimitar os erros de tipo e de proibição também quanto às normas penais em branco. ${ }^{774}$

Por outro lado, a ideia de que a delimitação entre o dolo e a consciência da ilicitude não seria possível também se mostra presente nas concepções de autores partidários da teoria da culpabilidade. ${ }^{775}$

Como se mencionou, um setor doutrinário aplica os postulados da teoria do dolo aos erros de proibição que incidem sobre as leis penais especiais. Outros autores, partindo da aplicação geral dos postulados da teoria da culpabilidade, tentam desenvolver critérios que permitam determinar se a existência da norma de complemento do tipo integra ou não o tipo penal para os casos de normas penais em branco. ${ }^{776}$

\footnotetext{
${ }^{771}$ FAKHOURI GÓMEZ, Yamila. Teoría del dolo vs. teoría de la culpabilidad: un modelo para afrontar la problemática del error en derecho penal, cit., p. 14.

${ }^{772}$ SUAY HERNÁNDEZ, Celia. Los elementos normativos y el error. Anuário de Derecho Penal y Ciencias Penales, ADPCP, Madrid, t. XLIV, fasc. 1, p. 125, 1991.

${ }^{773}$ DÍAZ Y GARCÍA CONLLEDO, Miguel. El error sobre elementos normativos del tipo penal, cit., p. 317 y ss., 378 y ss.

${ }^{774}$ FAKHOURI GÓMEZ, Yamila. Teoría del dolo vs. teoría de la culpabilidad: un modelo para afrontar la problemática del error en derecho penal, cit., p. 15.

${ }^{775}$ Id., loc. cit.

${ }^{776}$ Id., loc. cit. A autora menciona outros autores que adotam este posicionamento: HERZBERG, em GA, 1993, p. 457 e ss.; LAUER, Der Irrtumüber Blankettstrafgesetzeam Beispieldes $§ 106$ UrhG, 1997, p. 121 e ss. PUPPE, em GA, 1990, pp. 162; SCHWEGLER, Subsumtionsirrtum, 1995, pp. 77, 116, 140, 148; TIEDEMANN, Tatbestandsfunktionenim Nebenstrafrecht. Untersuchungenzueinemrechtstaatlichen Tatbestandsbegriff, entwickelt am Problem des Wirtschaftsstrafrechts, 1969, pp. 327 e ss., 385 e ss.
} 
À margem destas teses doutrinárias, alguns autores consideram a necessidade de conhecer a proibição para afirmar o dolo em alguns casos: assim, em certos casos, ele independe da própria formação típica (crime de desobediência, por exemplo). O conhecimento da proibição é exigido mesmo nos casos de crimes tributários e nos casos de normas penais em branco que remetem a outras administrativas ou mesmo judiciais. ${ }^{777}$ É o que se passaria com os crimes de mera desobediência ou mera transgressão, como, por exemplo, o delito do art. 51 da Lei 9.605/1998 (“comercializar motosserra ou utilizá-la em florestas e nas demais formas de vegetação, sem licença ou registro da autoridade competente").

Com base nestas propostas, o tratamento do erro seria equivalente ao derivado da aplicação dos postulados da teoria do dolo. Isto reforça a ideia de que, embora atualmente a relevância da distinção entre as teorias do dolo e da culpabilidade tenha perdido a importância, são poucos os autores que admitem abertamente tomar partido da primeira teoria (dolo). Certo é que o debate ressurge em face das normas penais em branco.

A proximidade verificada entre a tipicidade e a ilicitude resta patente também por causa do desenvolvimento, por Roxin, da categoria dos elementos de dever jurídico. Para ele, os elementos de valoração global se distinguiriam dos elementos normativos porque o conhecimento dos primeiros de identificaria com o conhecimento da ilicitude formal da conduta. ${ }^{778}$ Esta solução, apresentada pelo doutrinador alemão entende que os elementos de dever jurídico são "elementos de valoração global do fato", de modo que se diferenciam dos pressupostos fáticos da valoração e da valoração em si mesmo considerada. Neste sentido, o erro sobre os pressupostos fáticos da valoração configurará um erro de tipo, excluindo o dolo. Todavia, a valoração equívoca representará erro de proibição, em nada interferindo no dolo. ${ }^{779}$ Desta forma, verifica-se que elementos como "sem autorização" e "reprovável" não serviriam apenas à descrição do fato, mas também incluiriam o juízo sobe a ilicitude. Para ilustrar o pensamento de Roxin, Luís Greco e Alaor Leite exemplificam: "o vizinho de A sai de viagem por uma semana e pede a A que abra as cartas que porventura chegarem nesse ínterim. Uma semana depois, o vizinho retorna, mas A, que disso não se apercebe e não se lembra de que dia se trata, abre uma carta dirigida a

\footnotetext{
${ }^{777}$ MIR PUIG, Santiago. La distinción de error de tipo y error de prohibición en derecho penal. In: CGPJ Consejo General del Poder Judicial Derecho Judicial (Ed.). El consentimiento. El error. Madrid, 1993. p. 205. DÍAZ Y GARCÍA CONLLEDO, Miguel. El error sobre elementos normativos del tipo penal, cit., p. 431.

${ }^{778}$ LUZÓN PEÑA, Diego Manuel. Curso de derecho penal: parte general. Madrid: Civitas, 1996. v. 1, p. 353 , 355, e seu discípulo DÍAZ Y GARCÍA CONLLEDO, Miguel. El error sobre elementos normativos del tipo penal, cit., p. 113 e ss., 427, 432, entre outros.

${ }^{779}$ GRECO, Luís; LEITE, Alaor. Claus Roxin, 80 anos. Revista Liberdades, n. 7, maio/ago. 2011.
} 
seu vizinho. Aqui, A erra sobre um pressuposto fático da valoração, agindo, portanto, sem dolo. Se A, porém, sabendo do retorno do vizinho, supuser que nada há de indevido em continuar a abrir-lhe a correspondência - afinal, são grandes amigos! - ele agirá dolosamente, sendo de admitir-se mero erro de proibição (evitável)."780

Welzel já se aproximava desta solução baseando-se na ideia de que alguns dos elementos contidos nos tipos penais constituiriam elementos do dever jurídico, relativos à ilicitude. $\mathrm{O}$ erro sobre eles equivaleria ao erro de proibição. No entanto, apesar do entendimento do autor alemão, poder-se-ia estabelecer outra conclusão: em vez de deixar estes itens fora do âmbito de conhecimento que necessita ter o autor para verificar-se a responsabilidade dolosa, seria preciso repensar a correção dos postulados da teoria da culpabilidade, que levaram à eliminação de consciência da ilegalidade do âmbito do dolo. $^{781}$

A situação relativa ao conhecimento dos elementos típicos e o conhecimento da ilicitude não decorreria apenas dos elementos mencionados, mas teria reflexos não necessariamente explicitados por outros autores.

Assim, afirma-se que, em geral, a própria redação do tipo penal exporia o caráter injusto da conduta. Isto significa que o conhecimento das circunstâncias típicas se identificaria com o conhecimento da proibição, não sendo possível delimitar os diferentes conteúdos de consciência sobre os quais recai o erro de tipo e de proibição. Neste sentido Jakobs entende que o desconhecimento da norma por parte de alguém imputável somente poderia se dar em face de uma realidade estranha, não cotidiana, que não fosse familiar ou, ainda, quando não se vislumbrassem claramente aspectos do convívio social em processo de mudança. ${ }^{782}$

O caráter de perturbação social do fato resultaria patente quando o legislador introduz no tipo penal elementos com o conteúdo normativo, entendendo-se por tais elementos aqueles que designam fatos sociais que, por sua vez, adquirem relevância desde uma perspectiva jurídica. $\mathrm{Na}$ terminologia adotada por Searle, seriam fatos

\footnotetext{
${ }^{780}$ GRECO, Luís; LEITE, Alaor. op. cit.

${ }^{781}$ FAKHOURI GÓMEZ, Yamila. Teoría del dolo vs. teoría de la culpabilidad: un modelo para afrontar la problemática del error en derecho penal, cit., p. 17.

${ }^{782}$ JAKOBS, «Normkenntnis und Normunkenntnis», en Probleme und Aufgaben des modernen Strafrechts. Festschriftfür Hyung Kook Lee zum 60. Geburtstag, 1998, p. 924, apud FAKHOURI GÓMEZ, Yamila. Teoría del dolo vs. teoría de la culpabilidad: un modelo para afrontar la problemática del error en derecho penal, cit., p. 17.
} 
institucionais. ${ }^{783}$ Neste ponto, seria indiferente se o elemento faz ou não uma remissão a outra norma do ordenamento para obter o elemento do fato. O tipo penal e o elemento que introduz a remissão teriam, também nestes casos, base normativa.

Assim, o conhecimento de que a conduta significa "matar", "danificar" etc., não poderia ser separado do conhecimento de que tal conduta é contrária à norma. Igualmente, ser consciente da circunstância de que se está pescando fora do período autorizado não poderia dissociar-se do conhecimento de que tal conduta encontra-se proibida. Sobre o caráter alheio de uma coisa, o dolo do autor estaria verificado quando se conhece a existência de normas reguladoras da propriedade que outorgam a uma pessoa o poder de dispor da coisa, negando-se tal potestade a outras pessoas. O dolo se identificaria com o conhecimento de que a coisa é propriedade de outrem. A valoração paralela que a doutrina exige para a afirmação do dolo não se dissociaria, nos casos concretos, do conhecimento da proibição.

Quanto a estes e outros delitos, a regulamentação do erro de proibição resultaria supérflua: nos casos em que a leitura do tipo penal permitisse reconhecer o significado de injusto da conduta, a função de chamada do dolo não poderia distinguir-se do conhecimento latente da proibição. Isto somente seria diferente quando se desconhece a situação fática, de maneira que não saiba que realiza o tipo penal, ou quando se pensa que sua conduta restou justificada, somente nestes casos excluindo-se o dolo (dolus malus).

Neste ponto impende mencionar alguns casos em que o conhecimento da proibição não se desligaria de forma automática, não constituindo erro sobre causas de justificação relativamente a estes delitos: por exemplo, todos sabem que obrigar pessoas a manterem relações sexuais contra sua vontade é proibido, mas isto vale para a própria esposa? Igualmente sabe-se que é proibido ter relações sexuais com menores. Mas e com jovens de 12 ou 13 anos? Não obstante, ao tratar de casos limites, duvidosos, o conhecimento da ilicitude deverá ser demonstrado de forma apartada, conforme se verifica abaixo.

Verifica-se que quanto a certos tipos penais o conhecimento dos elementos típicos não revelaria de imediato o caráter do injusto do fato. Casos paradigmáticos seriam os dos delitos de perigo abstrato, que se caracterizam porque a conduta não se proíbe por si mesma, mas por suas possíveis consequências. Nestes casos, a ocorrência do dolo exigiria que o sujeito conhecesse os elementos do tipo (dolo natural) unido ao conhecimento da

\footnotetext{
${ }^{783}$ SEARLE, John Rogers. Actos de habla: ensayo de filosofia del lenguaje. Madrid: Planeta, 1980. p. 58 e ss.
} 
proibição (dolus malus) já que deste modo caberia afirmar que se conhece fatos sociais com relevância jurídica quando se lhe imputa atuação a título de dolo. ${ }^{784}$

Para poder afirmar a responsabilidade dolosa, o dolo deveria poder exercer sua função de chamada, que se encontra relacionada com o conhecimento da proibição. Relativamente aos tipos penais nos quais nem sequer caberia falar de uma função de chamada, o desconhecimento da proibição implicaria a exclusão da responsabilidade por dolo (dolus malus).

Entre as situações cuja identificação entre o conhecimento típico e o da ilicitude é claro, também existem casos cuja diferenciação não se mostra tão evidente, de modo que a interpretação para um lado ou outro poderá ser feita de forma razoável. Não poderia ser de outra forma, tendo-se em vista que o Direito é ciência social e, como tal, não necessariamente precisa.

\subsection{Síntese das concepções doutrinárias relativas ao erro de proibição}

Em sede de culpabilidade espera-se ter deixado claro que o erro de proibição relaciona-se com o âmbito de conhecimento do injusto. Neste sentido Juarez Cirino dos Santos aponta as respostas para que se possa identificar o que o autor de uma conduta deve saber para que se afirme conhecer a ilicitude do fato.

Dentre as respostas apresentadas pelo mencionado autor, encontra-se a que localiza o conhecimento na ilicitude material ou no conhecimento da contradição entre o comportamento real e a ordem comunitária, que permitiria ao leigo saber que seu comportamento infringe o ordenamento jurídico (público, civil, penal etc.) ou moral, independentemente de conhecer o bem jurídico ou a punibilidade do fato. ${ }^{785}$ Tangerino afirma que, com variações internas, é este o posicionamento adotado por Kaufman e Rudolphi, na Alemanha, por Figueiredo Dias, em Portugal e, ainda, representa o entendimento preponderante na doutrina brasileira, fortemente influenciada por Welzel. ${ }^{786}$

\footnotetext{
${ }^{784}$ MIR PUIG, Santiago. La distinción de error de tipo y error de prohibición en derecho penal, cit., p. 208 y s.; MOLINA FERNANDEZ, Fernando. Antijuridicidad penal y sistema del delito, cit., p. 478 y ss., 481 y ss., 676 y ss., 842 .

${ }^{785}$ SANTOS, Juarez Cirino dos. Direito penal: parte geral. 2. ed. Rio de Janeiro: Lumen Juris, 2007. p. 304306.

${ }^{786}$ TANGERINO, Davi de Paiva Costa. Culpabilidade. Rio de Janeiro: Campus Jurídico; Elsevier, 2011. p. 188.
} 
Bitencourt asseverou que a doutrina, acompanhando o pensamento de Binding, vinha aceitando a "consciência profana do injusto, constituída do conhecimento da antissocialidade, da imoralidade ou da lesividade de sua conduta", que proviria "das normas de cultura, dos princípios morais e éticos, enfim, dos conhecimentos adquiridos na vida em sociedade." Este critério, todavia, não se sustenta porque como se mencionou, "nem sempre o dever jurídico coincide com a moral”, de modo que o Direito também protege "situações amorais e até imorais, contrastando com a lei moral, por razões de política criminal, de segurança social etc.". ${ }^{787}$ Este raciocínio foi o que inspirou Welzel quando da edificação da nova estrutura da culpabilidade. Assim, não bastando invocar a falta de consciência do ilícito para inocentar-se, devendo-se indagar da possibilidade de adquiri-la e, havendo-a, se houve negligência em não adquiri-la ou, ainda, a falta de dever de procurar esclarecer-se sobre a ilicitude da conduta. ${ }^{788}$

Tal cenário é o incorporado pelo nosso Código Penal, precisamente no art. 21. Quanto a isto, Assis Toledo mencionou que não aproveita ao agente o desconhecimento da ilicitude quanto “a) teria sido fácil para ele, nas circunstâncias, obter essa consciência com algum esforço de inteligência e com os conhecimentos hauridos na vida comunitária de seu próprio meio; b) propositalmente (...) recusa-se a instruir-se para não ter de evitar uma possível conduta proibida; c) não procura informar-se convenientemente, mesmo sem má intenção, para o exercício de atividades regulamentadas". 789

Outra resposta, apresentada por Juarez Cirino dos Santos, para que se possa identificar o que o autor de uma conduta deve saber para que se afirme conhecer a ilicitude do fato consubstancia-se na proposta de Otto e Neumann, fundamentando-se que o objeto da consciência do injusto é a punibilidade do fato. Desta forma, "a consciência do injusto significa conhecimento da punibilidade do comportamento por meio de uma norma legal penal positiva", portanto relacionando-se com a "consciência de infringir uma prescrição penal", embora não se possa exigir o preciso conhecimento quanto aos dispositivos legais violados. $^{790}$

Por fim, verifica-se a doutrina de Roxin, que entende ser suficiente para configurar o conhecimento da ilicitude a consciência quanto à danosidade social ou imoralidade da ação, não sendo preciso que se conheça a punibilidade porque o conhecimento relativo à

\footnotetext{
${ }^{787}$ BITTENCOURT, Cezar Roberto. Tratado de direito penal: parte geral, cit., p. 376.

${ }^{788}$ TANGERINO, Davi de Paiva Costa. op. cit., p. 195.

${ }^{789}$ TOLEDO, Francisco de Assis. Princípios básicos de direito penal, cit., p. 260.

${ }^{790}$ SANTOS, Juarez Cirino dos. Direito penal: parte geral, cit., p. 304-306.
} 
proibição do fato por qualquer ramo do Direito já bastaria para a configuração do conhecimento da ilicitude, mesmo na esfera penal. ${ }^{791}$ Este também é o entendimento do Supremo Tribunal Alemão e representa o conhecimento da proibição concreta do tipo de injusto. $^{792}$

Verifica-se, pois, que a primeira resposta/teoria incorpora a racionalidade fundada num conhecimento cotidiano das atuações de cada um, isto é, basta que se conheça o cotidiano do que é certo ou errado para que não haja incidência do erro de proibição. Por isso se disse que esta concepção aproxima-se do que Rudolphi e Welzel defenderam quanto à necessidade de que o agente conheça que seu comportamento contraria valores jurídicos.

A resposta/teoria defendida por Roxin, exigindo-se que o objeto do erro seja a relação concretamente verificada entre o sujeito e o bem jurídico, mostra-se vinculada à perspectiva de que cabe ao Direito Penal a punição de atos previstos como ilícitos embora não criminosos. Isto porque se a função do Direito Penal é impedir a reiteração de condutas ilícitas, "quem comete um ilícito crendo-o mera infração civil, sendo, porém, um delito, não estaria agindo em erro de proibição, eis que sabia que sua ação atentaria contra o ordenamento jurídico, amplamente considerado". ${ }^{793}$ Este posicionamento, no entanto, é criticado porque contraria o "âmbito elementar de previsibilidade das ações dos sujeitos". 794

Já a perspectiva de Otto e Neumann de que a "consciência do injusto no sentido de consciência da antijuridicidade é conhecimento da punibilidade do comportamento por meio de uma norma penal positivada" em que não se exigiria o conhecimento da letra da lei, mas de que se transgride norma penal. Isto porque há atos "juridicamente corrigíveis" e atos "puníveis", sendo que "enquanto o ordenamento jurídico se satisfaz, no primeiro caso, com a restauração da situação jurídica, sem opor uma reprovação ao lesionador da obrigação, quando afirma, na segunda situação, sua desaprovação em face do autor, pune seu ato", e isso gera a "especificação do conhecimento jurídico da proibição (norma proibitiva penal)." ${ }^{, 795}$ Em suma, nesta concepção, o conteúdo do erro de proibição deve ser

\footnotetext{
${ }^{791}$ TANGERINO, Davi de Paiva Costa. op. cit., p. 188-189.

${ }^{792}$ SANTOS, Juarez Cirino dos. Direito penal: parte geral, cit., p. 305.

${ }^{793}$ TANGERINO, Davi de Paiva Costa. op. cit.

${ }^{794}$ Id. Ibid.

${ }^{795}$ Id. Ibid.
} 
o juízo equívoco sobre uma conduta que viola norma penal, sendo insuficiente a relação concreta com o bem jurídico.

Apesar de se dizer que é fundamental, para evitar a incidência do erro de proibição, que o agente tenha tido a oportunidade de verificar a legalidade de sua conduta e a verificação da juridicidade de seu comportamento, haveriam situações como decisões judiciais e decisões administrativas aptas a viciar a certeza do autor quanto à sua conduta, bem como questões sobre a certeza de se saber que está a violar um bem jurídico e, até mesmo, de que aquele comportamento está regulamentado.

Note-se que não é nada fácil optar por uma teoria que atenda plenamente os desafios advindos da expansão penal. 


\section{CONCLUSÕES}

1. É indispensável, para que se disserte sobre o conhecimento da ilicitude, considerar, dentre os conceitos de delito, em especial, o analítico, cuja formação histórica acompanhou as tendências filosóficas de cada época de forma que sem que houvesse tal ponderação inviabilizar-se-ia o estudo do conhecimento da ilicitude nos tempos atuais.

2. Apesar das distintas tendências filosóficas que se prestaram a estruturar o conceito analítico de delito, não se chegou a formar um consenso quanto a composição numérica dos seus elementos que, todavia sempre contaram alguns dos seguintes: tipicidade, ilicitude, culpabilidade e punibilidade nas formulações. Os diversos posicionamentos quanto a estrutura analítica na teoria do delito irradiaram, por sua vez, importantes consequências teóricas relativas a localização do conhecimento da ilicitude, tendo ocupado lugar no dolo (tipicidade) e, igualmente, na culpabilidade.

3. As consequências da existência de diferentes entendimentos quanto a teoria analítica do delito não se resumem à localização do elemento relacionado ao conhecimento da ilicitude, mas toca a necessidade de proceder releitura do instituto, não sendo suficiente que se imponham perspectivas de atualidade ou potencialidade do conhecer em um simples raciocínio derivado dos elementos formadores do dolo e da culpabilidade.

4. Também o conceito material de delito deve ser tido em consideração para o estudo e análise do conhecimento da ilicitude porque será a partir do que a sociedade entender como objeto de reprovação é que serão estruturados os mecanismos que possam se prestar a estipular quais condutas não serão socialmente toleradas nos âmbitos penal e não penal.

5. A partir da constatação e aplicação da técnica legislativa da criação de tipos penais de perigo abstrato e de normas penais em branco, e inobstante a necessária observância do conceito analítico, igualmente se faz necessário ponderar o próprio conceito material de delito porquanto as características vislumbradas a partir dos fenômenos expansivo-penais inserem novas perspectivas político-criminais quanto a necessidade e pertinência de novos tipos penais. Isto refletirá 
inexoravelmente no conhecimento da ilicitude na especial medida em que estas características expansivas dificultam objetivar a ilicitude penal.

6. A atual política criminal adotada no país não apresenta resultados integralmente proveitosos, embora não se negue que os princípios mostrem-se linhas mestras na busca da efetiva limitação da ilicitude penal. A relação e os problemas que advém do Direito Penal e do Administrativo Sancionador devem ser observadas sob a ótica de uma política jurídica, embora não se tenha observado soluções práticas dotadas de unanimidade.

7. Estudos teóricos, não dotados de unanimidade, sobre o Direito Administrativo Sancionador e possíveis vertentes, como o Direito de Intervenção e o Direito de Velocidades demonstram a dificuldade em distinguir as formas de ilicitude e, consequentemente, indicam a necessidade de que seja repensada a culpabilidade quanto ao elemento conhecimento da ilicitude. Quanto à diferenciação do Direito Penal para o Administrativo Sancionador, inexiste clareza quanto aos âmbitos de existência das ilicitudes penal e administrativo-sancionadora, o que importa zonas de penumbra onde não são identificados as ilicitudes mencionadas.

8. Critérios pautados em orientações ontológicas, qualitativas ou qualitativasquantitativas representam abordagens periféricas, muitas vezes representando pura retórica, fugindo-se do principal ponto a ser discutido. Pensando-se também nas finalidades das penas, a eficiência pode ser um critério importante para a escolha entre os ramos penal e administrativo sancionador, o que, sendo aplicado para que haja a diferenciação, trará subsídios para a delimitação do conhecimento da ilicitude penal.

9. As teorias do erro embora não tenham igualmente obtido consenso doutrinário, ao longo dos tempos, representam importantes mecanismos para aplicação do direito penal às diferentes realidades fáticas, pessoais e sociais. A (in)evitabilidade dos erros, considerando-se o contexto da expansão penal ganha nova importância, tendo-se em vista a avalanche de novas normas surgidas e, ainda, em decorrência da aceitação de técnica legislativa específica que adota tipos penais de perigo e normas penais em branco.

10. No âmbito de discussão que envolve a expansão penal e o conhecimento da ilicitude, verifica-se que, na prática, não há grande quantidade de julgados que 
faça menção a esta situação, o que não significa que a temática não tenha sido levada aos Tribunais. Há diversos casos em que se nota a não apreciação da tese por conta da forma / momento ventilados. É o que se extrai dos inúmeros julgados proferidos pelo Superior Tribunal de Justiça onde se lê, por exemplo, que a análise das alegações concernentes a ocorrência de erro de proibição demandaria o revolvimento do conjunto fático-probatório, inviável em sede de habeas corpus.

11. São poucas as decisões onde se pode verificar a utilização técnica do conhecimento da ilicitude e normas correlacionadas, havendo significativo número de casos onde o mero argumento de que o desconhecimento da lei não escusa é utilizado sem qualquer aprofundamento no estudo do (des)conhecimento. 


\section{REFERÊNCIAS BIBLIOGRÁFICAS}

ABRAMS, Norman. Administrative process alternatives to the criminal process. Washington, D.C.: Law and Public Affairs Publication, National Center for Administrative Justice, 1979.

AGUADO CORREA, Teresa. El principio de proporcionalidad en derecho penal. Madrid: Edersa, 1999.

AlCHOURRON, C.; BULYGIN, E. Análisis lógico y derecho. Madrid: Centro de Estudios Constitucionales, 1991.

ALEXY, Robert. El concepto y la validez del derecho. Barcelona: Editorial Gedisa, 1994.

ANDREUCCI, Ricardo Antunes. Direito penal econômico e ilícito fiscal: estudos e pareceres de direito penal. São Paulo: Ed. Revista dos Tribunais, 1982.

ANGIONI, Francesco. Contenuto e funzioni del concetto di benne giuridico. Chiarella: Sassari, 1980.

ANTOLISEI, Francesco. Manual de derecho penal: parte general. 8. ed. Trad. Jorge Guerrero e Marino Ayerra Redín. Bogotá: Temis, 1988.

Manuale di diritto penale: parte generale. 14. ed. agg. e integrata a cura di Luigi Conti. Milano: Giuffrè, 1997.

ARIAS EIBE, José Manuel. El error en derecho penal en el Código de 1995. Madrid: Dykinson, 2007.

ARNHOLM, María. The system of administrative and penal sanctions in Sweden. Faculty of Law, Uppsala University, Swedish Society for European Criminal Law, 1996.

ARROYO ZAPATERO, Luis. Derecho y riesgo. Iniuria: revista de responsabilidade civil y seguro, n. 8, out./dez. 1995.

ATIENZA RODRIGUEZ, Manuel. Contribución a una teoría de la legislación. Civitas: Madrid, 1997.

AZEVEDO, Rodrigo Ghiringhelli de. Criminologia contemporânea. Porto Alegre: TRF $4^{\text {a }}$ Região, 2008 (Currículo Permanente. Caderno de Direito Penal: módulo 4). 
AZEVEDO, Rodrigo Ghiringhelli de. Tendências do controle penal na modernidade periférica: as reformas penais no Brasil e na Argentina na última década. 2003. Tese (Doutorado em Sociologia) - Instituto de Filosofia e Ciências Humanas, Universidade Federal do Rio Grande do Sul, Porto Alegre, 2003.

BADARÓ, Gustavo Henrique Righi Ivahy. Lei n. 10.701 de 9 de julho de 2003: análise inicial das alterações da lei de lavagem de dinheiro. Boletim IBCCRIM, São Paulo, v. 11, n. 129, p. 8-9, ago. 2003.

BAJO FERNÁNDEZ, Miguel; SUÁREZ GONZÁLEZ, Carlos; PÉREZ MANZANO, Mercedes (Eds.). Manual de derecho penal: parte especial. Delitos patrimoniales y econômicos. 2. ed. Madrid: Centro de Estudios Ramón Areces, 1993.

BARATA, Francesc. Las nuevas fabricas del miedo: los "mass media" y la inseguridad ciudadana. In: MUÑAGORRI, Ignacio (Ed.). La protección de la seguridad ciudadana. Oñate: Instituto Internacional de Sociología jurídica de Oñate, 1995. p. 83-94. (Oñati Proceedings, n. 18).

BARATTA, Alessandro. Funciones instrumentales y simbólicas del derecho penal: uma discusión en la perspectiva de la criminologia crítica. Pena y Estado, Barcelona, n. 1, p. 37-55, 1991.

BATAGLINI, Giulio. Diritto penale: parte generale. Padova: Cedam, 1949.

BATALHA, Wilson de Souza Campos; RODRIGUES NETTO, Sílvia Marina L. Batalha de. Filosofia jurídica e história do direito. Rio de Janeiro: Forense, 2000.

BECHARA, Ana Elisa Liberatore Silva. Da teoria do bem jurídico como critério de legitimidade do direito penal. 2010. Tese (Livre-docência) - Faculdade de Direito da Universidade de São Paulo, São Paulo, 2010.

- Delitos de acumulação e racionalidade da intervenção penal. Boletim do IBCCRIM, São Paulo, n. 208, p. 3-5, mar. 2003.

BECK, Ulrich. De la sociedad industrial a la sociedad del riesgo. Revista de Occidente, n. 150, nov. 1993.

BERGALLI, Roberto. Relaciones entre control social y globalización: Fordismo y disciplina, Post-fordismo y control punitivo. Revista Sociologías, Porto Alegre, ano 7, n. 13, p. 180-211, jan./jun. 2005.

BERGER, Raoul. Administrative arbitrariness and judicial review. Columbia Law Review, n. $65,1965$. 
BETTI, Stefano. New prospects for inter-state co-operation in criminal matters: the Palermo Convention. International Criminal Law Review, n. 3, p. 151-167, 2003.

BETTIOL, Giuseppe. Direito penal. Tradução de Paulo José da Costa Jr. e Alberto Silva Franco. São Paulo: Ed. Revista dos Tribunais, 1966. v. 1.

Direito penal. Tradução de Paulo José da Costa Jr. e Alberto Silva Franco. Notas de Everardo da Cunha Luna. São Paulo: Ed. Revista dos Tribunais, 1971. v. 2.

BIANCHINI, Alice. Pressupostos mínimos da tutela penal. São Paulo: Ed. Revista dos Tribunais, 2002.

BISBAL MÉNDEZ, Joaquim. La responsabilidad extracontractual y la distribución de los costes del progreso. Revista de Derecho Mercantil, n. 167/168, 1983.

BITENCOURT, Cezar Roberto. Erro de tipo e de proibição: uma análise comparativa. 2. ed. São Paulo: Saraiva, 2000.

. Erro de tipo e erro de proibição. São Paulo: Saraiva, 2010.

Tratado de direito penal: parte geral. 13. ed. São Paulo: Saraiva, 2008.

BLANCO LOZANO, Carlos. Tratado de política criminal: la política criminal aplicada. Barcelona: Bosch, 2007. t. 2.

BONAFÉ-SCHMITT, Jean Pierre. La médiation, une justice douce. Paris: Syros, 1992.

BORDA, Guillermo. Error de hecho y de derecho: su influencia en la anulación de los hechos jurídicos. Buenos Aires: Perrot, 1950.

BOTTINI, Pierpaolo Cruz. Crimes de perigo abstrato e princípio da precaução na sociedade de risco. São Paulo: Ed. Revista dos Tribunais, 2007.

BRUNO, Aníbal. Direito penal: parte geral. 5. ed. rev. e atual. por Raphael Cirigliano Filho. Rio de Janeiro: Forense, 2003. t. 1.

BUSTOS RAMIREZ; Juan. Introducción al derecho penal. Bogotá: Temis, 1994.

. El tratamiento del error en la reforma de 1983: art. 6 bis a. Anuário de Derecho Penal y Ciencias Penales, ADPCP, t. 38, n. 3, sept./dic. 1985.

CAAMAÑO, F. Garantía constitucional de la inocência. Valencia: Tirant lo Blanch, 2003.

CAMARGO, Antonio Luis Chaves. Imputação objetiva e direito penal brasileiro. São Paulo: Cultural Paulista, 2002. 
CANCIO MELIÁ, Manuel. Derecho penal del enemigo y delitos de terrorismo: algunas consideraciones sobre la regulación de las infracciones en materia de terrorismo en el Código Penal (LGL 194012) español después de la Lei Orgânica 7/2000. Derecho Penal Contemporáneo, Revista Internacional, v. 3, 2003.

CAPPELETTI, Mauro. O acesso dos consumidores à justiça. In: TEIXEIRA, Salvio de Figueiredo (Org.). As garantias do cidadão na justiça. Saraiva: São Paulo, 1993.

CARNELUTTI, Francesco. Teoria general del delito. Trad. Victor Conde. Madrid: Editorial Revista de Derecho Privado, 1952.

Teoria generale del reato. Secondo migliaio. Padova: CEDAM, 1933.

CARNEVALI RODRIGUEZ, Raúl. Derecho penal y derecho sancionador de la Unión Europea. Granada: Comares, 2001.

CARRARA, Francesco. Programa del curso de derecho penal: parte general. Traducción de la 11. ed. italiana por Sebastin Soler con la colaboración de Ernesto Gavier y Ricardo Nuñez. Buenos Aires: Depalma, 1944. v. 6.

Programa do curso de direito criminal: parte geral. Trad. Ricardo Rodrigues Gama. Campinas: LZN, 2002. v. 1.

CARVAlHO, Américo A. Taipa de. Direito penal: parte geral. Porto: Publicações Universidade Católica, 2003.

CEREZO MIR, José. Curso de derecho penal español: parte general. Madrid: Tecnos, 1985.

. Curso de derecho penal español: parte general. 6. ed. Madrid: Tecnos, 2004. v. 1.

- La regulación del error de prohibición en el Código penal español y su trascendencia en los delitos monetarios. Anuário de Derecho Penal y Ciencias Penales, ADPCP, Madrid, 1985.

CHAMBLISS, William J.; BAER, Justin. Generating fear: the politics of crime reporting. Crime Law and Social Change, v. 27, n. 3, p. 87-107, 1997.

CHARNEY, Jonathan I. The need for constitutional protections for defendant in civil penalty cases. Cornell Law Review, v. 59, 1974.

CID MOLINÉ, José. Garantías y sanciones (argumentos contra la tesis de la identidad de garantías entre las sanciones punitivas). Revista de Administración Pública, n. 140, p. 131174, 1996. 
COBO DEL ROSAL, Manuel; VIVES ANTÓN, Tomá S. Derecho penal: parte general. 4. ed. (adecuada al Código penal de 1995 por María Isabel Valldecabres Ortiz). Valencia: Tirant lo Blanch, 1996.

; ___ Derecho penal: parte general. 5. ed. Valencia: Tirant lo Blanch, 1999.

CODERCH, Pablo Salvador; CASTIÑEIRA PALOU, Maria Teresa. Prevenir y castigar. Madrid: Marcial Pons, 1997.

COELHO, Walter. O direito penal e o novo Código Penal brasileiro (coletivo). Porto Alegre: Sergio Antonio Fabris Editor, 1985.

CORCOY BIDASOLO, Mirentxu. Delitos de peligro y protección de bienes jurídicopenales supraindividuales. Valencia: Tirant lo Blanch, 1999.

CÓRDOBA RODA, Juan. El conocimiento de la antijuridicidad en la teoría del delito. Barcelona: Bosch, 1962.

El conocimiento de la antijuridicidad en la teoría del delito. Barcelona: Bosch, 1992.

CORREIA, Eduardo. Direito penal e direito de mera ordenação social: direito penal económico e europeu: textos doutrinários Coimbra: Coimbra Ed., 1998. v. 1.

CORTINA, Adela. Ética aplicada y democracia radical. Madrid: Tecnos, 1997.

Hasta un pueblo de demonios: ética pública y sociedad. Madrid: Taurus, 1998.

COSTA, Helena Regina Lobo da. Proteção penal ambiental: viabilidade, efetividade, tutela por outros ramos do direito. São Paulo: Saraiva, 2010.

COSTA JUNIOR, Paulo José da. Comentários ao Código Penal: parte geral. São Paulo: Saraiva, 1986.

Direito penal ecológico. Rio de Janeiro: Forense, 1996.

CRESPO, Eduardo Demetrio. Do direito penal liberal ao direito penal do inimigo. Revista de Ciências Penais, São Paulo, n. 1, p. 9-37, dez. 2004.

Prevención general e individualización judicial de la pena. Prólogos de Ignácio Berdugo e Hans Joachim Hirsch. Salamanca: Universidad de Salamanca, 1999. (Acta salmanticensia estudios jurídicos, 79).

CRESPO, Marcelo Xavier de Freitas. Crimes digitais. São Paulo: Saraiva, 2011. 
CRESPO, Marcelo Xavier de Freitas. Direito penal do inimigo: sobre o que estamos falando? Boletim IBCCRIM, São Paulo, ano 16, n. 196, p. 3, mar. 2009.

CUNHA, Maria da Conceição Ferreira da. Constituição e crime: uma perspectiva da criminalização e da descriminalização. Porto: Universidade Católica Portuguesa, 1995.

DE DOELDER, Hans. The system of administrative and penal sanctions. In: Europäische Kommision: the system of administrative and penal sanctions in the Member States of the European Communities. Luxemburg: National Reports, 1994. v. 1, p. 299-301.

DE LA CUESTA AGUADO, Paz M. Conocimiento de la ilicitud: aproximación al conocimiento de la antijuridicidad del hecho desde las teorías psicológicas del pensamiento intuitivo. Madrid: Dykinson, 2007.

DE PALMA DEL TESO, Ángeles. El principio de culpabilidad en el derecho administrativo sancionador. Madrid: Tecnos, 1996.

DEBBASCH, Charles. Ciencia administrativa. Administración pública. 2. ed. rev. y aumen. Traducida por José Antônio Colás Leblanc. Madrid: Instituto Nacional de Administración pública, 1981.

DEL ROSAL, Juan. Tratado de derecho penal español: parte general. 3. ed. Madrid: Aguirre, 1978. v. 1.

DELITALA, Giacomo. El "hecho" em la teoria general del delito. Buenos Aires: B de F, 2009. (Maestros del derecho penal, 29).

DELMAS-MARTY, Mireille. I problemi giuridici e pratici posti dalla distinzione tra diritto penale amministrativo. Rivista Italiana di Diritto e Procedura Penale, Milano, n. 48, 1987.

DESABAFO de um promotor sobre a Lei 12.403/2011. Disponível em: $<$ http://www.direitolegal.org/artigos/desabafo-de-um-promotor-sobre-a-lei-12-4032011/>. Acesso em: 09 out. 2011.

DIAS, Jorge de Figueiredo. Direito penal: parte geral. Coimbra: Coimbra Ed. 2004. t. 1.

Direito penal: parte geral: questões fundamentais: a doutrina geral do crime. 2. ed. portuguesa, 1. ed. brasileira. São Paulo: Ed. Revista dos Tribunais, 2007.

O direito penal entre a "sociedade industrial" e a "sociedade do risco". Revista Brasileira de Ciências Criminais, São Paulo, v. 33, ano 9, jan./mar. 2001.

Liberdade, culpa e direito penal. 3. ed. Coimbra: Coimbra Ed., 1995. 
DIAS, Jorge de Figueiredo. O problema da consciência da ilicitude em direito penal. 5. ed. Coimbra: Coimbra Ed., 2000.

O problema da consciência da ilicitude em direito penal. 3. ed. Coimbra: Coimbra Ed., 1987.

Sobre a autonomia dogmática do direito penal econômico: uma reflexão à luz do novo direito penal económico português. Estudios Penales y Criminológicos, n. 9, p. 37 70, 1984-1985.

Temas básicos da doutrina penal: sobre os fundamentos da doutrina penal, sobre a doutrina geral do crime. Coimbra: Coimbra Ed., 2001.

; ANDRADE, Manuel da Costa. Problemática geral das infracções contra a economia nacional. In: INSTITUTO DE DIREITO PENAL ECONÔMICO E EUROPEU. FACULDADE DE DIREITO DA UNIVERSIDADE DE COIMBRA. Direito penal económico e europeu: textos doutrinários. Coimbra: Coimbra Ed., 1998. v. 1.

DÍAZ Y GARCÍA CONLLEDO, Miguel. El error de prohibición: pasado, presente y futuro. In: CEREZO MIR, J.; SUÁREZ MONTES, R. E.; BERISTAIN IPIÑA, A.; ROMEO CASABONA, C. M. (Eds.). El nuevo Código Penal: presupuestos y fundamentos. Libro Homenaje al Profesor Ángel Torío López. Granada: Comares, 1999.

. El error sobre elementos normativos del tipo penal. Madrid: La Ley, 2008.

DÍEZ RIPOLLÉS, José Luís. Bien jurídico protegido en un derecho penal garantista. Jueces para la Democracia, Separata, n. 30, nov. 1997.

De la sociedad del riesgo a la seguridad ciudadana: un debate desenfocado. Revista Electrónica de Ciencia Penal e Criminología, Granada, n. 7, 2005. Disponível em: $<$ http://bdjur.stj.jus.br/xmlui/bitstream/handle/2011/40519/sociedad_riesgo_seguridad_ripo lles.pdf? sequence $=1>$.

El derecho penal simbólico y los efectos de las penas. Actualidad Penal, n. 1, 2001.

. Exigencias sociales y politica criminal. Claves de Razón Práctica, n. 85, set. 1998.

La categoría de la antijuridicidad en derecho penal. ADPCP, t. 44, fasc. 3, p. 715790, 1991.

Política criminal y derecho penal: estudios. Valencia: Tirant lo Blanch, 2003. 
DÍEZ RIPOLLÉS, José Luís. La racionalidad de las leyes penales: practica y teoría. Madrid: Trotta, 2003.

DOLCINI, Emilio. Sui rapporti fra técnica sanzionatoria penale e amministrativa. Rivista Italiana di Diritto e Procedura Penale, Milano, v. 48, p. 777-797, 1987.

DOMINGUEZ VILA, Antonio. Constitución y derecho administrativo sancionador. Madrid: Marcial Pons, 1997.

DONINI, M. Selettività e paradigma della teoria del reato. Rivista Italiana di Diritto e Procedura Penale, Milano, v. 40, n. 2, p. 338-394, apr./giug. 1997.

DORADO MONTERO, Pedro. Voz “Codigo Penal”. In: NUEVA enciclopedia jurídica española. Barcelona: F. Seix, 1985. v. 6.

DOVAL PAÍS, Antonio. Posibilidades y límites para la formulación de las normas penales: el caso de las leyes en Blanco. Valencia: Tirant lo Blanch; Universitat de Valéncia, 1999.

ESER, Albin. La tutela penale dell'ambiente in Germania. Trad. Catenacci. L'Indice Penale, n. 23, p. 231-247, 1989.

; Bjorn BURKHARDT. Derecho penal: cuestiones fundamentales de la Teoría del Delito sobre la base de casos de sentencias. Trad. Silvina Bacigalupo y Manuel Cancio. Madrid: Colex, 1995.

FAKHOURI GÓMEZ, Yamila. Delimitación entre error de tipo y de prohibición: las remisiones normativas: un caso problemático. Navarra: Civitas, 2009.

- Teoría del dolo vs. teoría de la culpabilidad: un modelo para afrontar la problemática del error en derecho penal. InDret: revista para análisis del derecho, Barcelona, n. 4, 2009.

FARIA, José Eduardo de Oliveira. O direito na economia globalizada. São Paulo: Malheiros Ed., 1999.

FEELEY, Malcom; SIMON, Jonathan. The new penology: notes on the emerging strategy of corrections and its implications. Criminology, London, n. 20, 1992.

FELIP I SABORIT, David. La delimitación del conocimiento de la antijuricidad: una aportación al estudio del error de prohibición. Tese (Doutorado) - Universitat Pompeu Fabra - Barcelona, Espanha, 1997.

FERRAJOLI, Luigi. Derecho y razón. 4.ed. Madrid: Trotta, 2000. 
FERRAJOLI, Luigi. Derechos y garantias: la ley más débil. Trad. Perfecto Andrés Ibañez e Andréa Greppi. Madrid: Trotta, 1999.

FERRARI, Eduardo Reale. Legislação penal antitruste: direito penal econômico e sua concepção constitucional. In: REALE JÚNIOR, Miguel; FERRARI, Eduardo Reale. Experiências do direito. Campinas: Millenium, 2004. p. 253-315.

; PASCHOAL, Janaina Conceição. Ficção x realidade: um pequeno ensaio sobre a otimização de políticas de segurança. Boletim IBCCRIM, São Paulo, v. 9, n. 107, p. 13-14, out. 2001.

FERREIRA, Ivette Senise. Tutela penal do patrimônio cultural. São Paulo: Ed. Revista dos Tribunais, 1995.

FERRI, Enrico. Princípios de direito criminal: o criminoso e o crime. Trad. Luiz de Lemos D’Oliveira. Campinas: Russel, 2003.

FIANDACA, Giovanni; MUSCO, Enzo. Diritto penale: parte generale. 5 ed. Bologna: Zanichelli, 2007.

FLETCHER, George P. El derecho y lo razonable. Trad. Donna y Barbero. Buenos Aires: Editorial de Belgrano, 1997.

FLORIAN, Eugenio. Trattato di diritto penale. Milano: Francesco Vallardi, 1910. v. 1.

FORCE, Robert. Administrative adjudications of traffic violations confronts the doctrine of separation of powers. Tulane Law Review, n. 49, 1975.

FRAGOSO, Heleno Cláudio. Antijuridicidade. Revista Brasileira de Criminologia e Direito Penal, Disponível em http://www.fragoso.com.br/ptbr/arq_pdf/heleno_artigos/arquivo42.pdf>. Acesso em: 28 jun. 2011.

FRANCO, Alberto Silva. Globalização e criminalidade dos poderosos. In: PODVAL, Roberto (Coord.). Temas de direito penal econômico. São Paulo: Ed. revista dos Tribunais, 2000 .

; STOCO, Rui et al. Código Penal e sua interpretação. 8. ed. São Paulo: Ed. Revista dos Tribunais, 2007.

FREITAS, Vladimir Passos de; FREITAS, Gilberto Passos de. Crimes contra a natureza. São Paulo: Ed. Revista dos Tribunais, 2000. 
FRISCH, Wolfgang. Tipo penal e imputación objetiva. Trad. Manuel Cancio, Meliá Beatriz de la Gándara Vallejo, Manuel Jaén Vallejo e Yesid Reyes Alvarado. Madrid: Constitución y Leys, 1995.

FUKUYAMA, Francis. A grande ruptura: a natureza humana e a reconstituição da ordem social. Tradução de Nivaldo Montingelli Jr. Rio de Janeiro: Rocco, 2000.

GALLO, Marcello. Premésse alla teoria della colpevolezza. Rivista Italiana di Diritto e Procedura Penale, Milano, fasc. 2, p. 395-436, 1949.

Il reato nel sistema degli illeciti. Rivista Italiana di Diritto e Procedura Penale, Milano, nuova serie, anno 42, fasc. 3, p. 769-801, lugl./sett. 1999.

GARCIA ALBERO, Ramón. La relación entre ilícito penal e ilícito administrativo: texto y contexto de las teorías sobre la distinción de ilícitos. In: QUINTERO OLIVARES, Gonzalo; MORALES PRATS, Fermín. El nuevo derecho penal económico: estudios penales en Memoria del professor José Valle Muñiz. Pamplona: Aranzadi, 2001.

GARCIA DE ENTERRIA, Eduardo. El problema jurídico de las sanciones administrativas. Revista Espanhola de Derecho Administrativo, Madrid, n. 10, 1976.

GARZON VALDES, Ernesto. El enunciado de la responsabilidad. DOXA, n. 19, 1996.

GIACOMO, Roberta Catarina; MACHADO, Fábio Guedes de Paula. Novas teses dogmáticas jurídico-penais para a proteção do bem jurídico ecológico na sociedade do risco. Revista Liberdades, v. 2, p. 39-55, 2009.

GOMES, Luiz Flávio. O efeito mais bombastico da nova lei de prisões-e-o-seguinte. Disponível em: <http://www.ipclfg.com.br/artigos-do-prof-lfg/o-efeito-mais-bombasticoda-nova-lei-de-prisoes-e-o-seguinte/>. Acesso em: 09 out. 2011.

_. Princípio da ofensividade no direito penal. São Paulo: Ed. Revista dos Tribunais, 2002.

GONZÁLES SEARA, Luis. Los sujetos del bienestar. Diario ABC, 29 dez. 1997.

GRACIA MARTÍN, Luis. Política criminal y dogmática jurídico penal del proceso de reforma penal en España (y II). APen, n. 2, 1994.

Prolegómenos para la lucha por la modernización y expansión del derecho penal

y para la crítica del discurso de resistencia. Valencia: Tirant lo Blanch, 2003. Apresentação de Bernd Schünemann. 
GRASSO, Giovanni. L'antecipazione dela tutela penale: i reati di pericolo e i reati di attentato. Revista Italiana di Diritto e Procedura Penale, Milano, 1997.

GRECO, Luís. Sobre o chamado direito penal do inimigo. Revista da Faculdade de Direito de Campos, ano 6, n. 7, dez. 2005.

; LEITE, Alaor. Claus Roxin, 80 anos. Revista Liberdades, n. 7, maio/ago. 2011.

GRECO FILHO, Vicente. Crime: essência e técnica. Boletim do Instituto Manoel Pedro Pimentel, São Paulo, v. 5, n. 21, p. 11-12, jul./set.. 2002

Tipicidade, bem jurídico e lavagem de dinheiro. In: COSTA, José de Faria; SILVA, Marco Antonio Marques da. (Coords.). Direito penal especial, processo penal e direitos fundamentais: visão luso-brasileira. São Paulo: Quartier Latin, 2006.

GREVE, Vagn; GULLMAN, Claus. The system of administrative and penal sanctions. Submitted to the EC Commission in accordance with a study contract of 19 september 1990. In: EUROPÄISCHE KOMMISION. The system of administrative and penal sanctions in the Member States of the European Communities. National Reports. Luxemburg, 1994. v. 1.

GUNTHER, Klaus. De la vulneración de um derecho a la infracción de um deber. Un "cambio de paradigma en el derecho penal?. In: INSTITUTO DE CIENCIAS CRIMINALES DE FRANKFURT (Ed.). La insostenible situación del derecho penal. Granada: Comares, 2000.

GUZMAN DALBORA, José Luis. Prólogo. In: DELITALA, Giacomo. El “hecho” em la teoria general del delito. Buenos Aires: B de F, 2009. (Maestros del derecho penal, 29).

HANDOLL, John. The system of administrative and penal sanctions. In: EUROPÄISCHE KOMMISION. The system of administrative and penal sanctions in the Member States of the European Communities. National Reports. Luxemburg, 1994. v. 1.

HARVEY, David. The condition of post modernity. Oxford: Blackwell, 1994.

HASSEMER, Winfried. La ciencia jurídico-penal en la Republica Federal Alemana. Anuário de Derecho Penal y Ciencias Penales, t. 46, fasc. 1, jan./abr. 1993.

Derecho penal simbólico y protección de bienes juridicos. Pena y Estado, Barcelona, n. 1, 1991.

História das ideias penais na Alemanha do pós-guerra. Trad. Carlos Eduardo Vasconcelos. Revista Brasileira de Ciências Criminais, São Paulo, v. 2, n. 6, p. 36-71, abr./jun. 1994. 
HASSEMER, Winfried. Lineamentos de una teoría personal del bien jurídico. Doctrina Penal, Buenos Aires, n. 12, p. 275-285, abr./set. 1989.

Persona, mundo y responsabilidad: bases para una teoria de la imputación en derecho penal. Traducción de Francisco Muñoz Conde y Maria del Mar Díaz Pita. Valencia: Tirant lo Blanch, 1999.

Perspectivas de uma moderna política criminal. Revista Brasileira de Ciências Criminais, São Paulo, v. 2, n. 8, p. 41-51, out./dez. 1994.

A preservação do ambiente por meio do direito penal. Conferência ministrada na Universidade Lusíada - Porto, no âmbito do I Congresso Internacional de Direito do Ambiente, com tradução simultânea do alemão por Carlos Eduardo Vasconcelos, adaptada para publicação por Paulo de Sousa Mendes. Notícias do Direito Brasileiro, nova série, UNB, n. 4, 2. sem. 1997.

A preservação do meio ambiente através do direito penal. Trad. Carlos Eduardo Vasconcelos, adaptada para publicação por Paulo de Souza Mendes. Revista Brasileira de Ciências Criminais, São Paulo, n. 22, 1998.

Segurança pública no Estado de Direito. Revista Brasileira de Ciências Criminais, São Paulo, v. 2, n. 5, p. 55-69, jan./mar. 1994.

HIRSCH, Hans Joachim. Acerca del estado actual de la discusión sobre el concepto de bien jurídico. In: MODERNAS tendências en la ciencia del derecho penal y en la criminología, Madrid: Universidad Nacional de Educación a Distancia, 2001.

El desarrollo de la dogmática penal después de Welzel. In: Derecho penal: obras completas. Livro Homenaje. Buenos Aires: Rubinzal-Culzoni Editores, 1999. t. 1.

HUERTA TOCILDO, Susana. Problemática del error sobre los presupuestos de hecho de una causa de justificación. CDJ, v. 18/20, p. 249-275, 1993. (El consentimiento. El error).

HUNGRIA, Nelson. Comentários ao Código Penal. 6. ed. Rio de Janeiro: Forense, 1958. v. 1 .

IBGE. 47,2\% das pessoas não se sentem seguras na cidade em que moram. Disponível em: $<$ http://www.ibge.gov.br/home/presidencia/noticias/noticia_visualiza.php?id_noticia=1786 \&id_pagina=1>. Acesso em: 09 out. 2011.

IMBERT, Gerard. Los escenarios de la violencia. Barcelona: Icaria, 1992. 
JAKOBS, Günther. Derecho penal: parte general: fundamentos y teoría de la imputación. Traducción: Joaquim Cuello Contreras; José Luis Serrano Gonzales de Murillo. Madrid: Marcial Pons, 1997.

- Estudios de derecho penal. Trad. Enrique Peñarada Ramos, Carlos Soárez González e Manuel Cancio Meliá. Madrid: Civitas, 1997.

La imputación objetiva en derecho penal. Trad. Cancio Melia. Madrid: Civitas, 1996.

Sociedad, norma, persona en una teoría de un derecho penal funcional. Trad. por Cancio Meliá y Bernardo Feijoó. Bogotá: Centro de Investigaciones de Derecho Penal y Filosofía del Derecho, 1996. (Cuadernos de conferencias y artículos n. 13).

; CANCIO MELIÁ, Manuel. Derecho penal del enemigo. Trad. Manuel Cancio Meliá. Madrid: Civitas, 2003.

JESCHECK, Hans-Heinrich. Tratado de derecho penal: parte general. Trad. Santiago Mir Puig e Francisco Muñoz Conde. 3. ed. Barcelona: Bosch, 1981.

Tratado de derecho penal: parte general. Traducción de José Luis Manzanares Samiego. 4. ed. Granada: Comares, 1993.

; WEIGEND, Thomas. Tratado de derecho penal: parte general. 5. ed. Traducción de Miguel Olmedo Cardenete. Granada: Comares, 2002.

JIMÉNEZ DE ASÚA, Luís. Princípios de derecho penal: la ley y el delito. Buenos Aires: Sudamericana, [s.d.].

Tratado de derecho penal. 2. ed. Buenos Aires: [s.n.], 1961.

Tratado de derecho penal. Buenos Aires: Editorial Losada, 1962. t. 6.

KANITZ, Stephen. Cuidado com o que ouvem. Veja, São Paulo, ed. 2028, 03 out. 2007. Disponível em: <http://veja.abril.com.br/031007/ponto_de_vista.shtml>. Acesso em: 09 maio 2012.

KAUFMANN, Armin. Teoría de las normas. Trad. de Enrique Bacigalupo e Ernesto Garzón Valdés: Buenos Aires: Depalma, 1977.

KÖSTER, Mariana Sacher de. Evolución del tipo subjetivo. Bogotá: Universidad Externado de Colombia, 1998. 
KUHLEN, Lothar. La autocompreensión de la ciencia jurídico-penal frente a los desafios de su tiempo. Trad. Pastora García Álvarez. La ciencia del derecho penal ante el nuevo milênio. Valencia: Tirant lo Blanch, 2004.

LASCANO, Carlos Julio. La insostenible 'modernización del derecho penal' basada en la 'tolerancia cero' desde la perspectiva de los países 'emergentes'. Disponível em <http://www.defensesociale.org/revista2003/10.pdfl>. Acesso em: 08 jun. 2011.

LASCURIÁN SÁNCHEZ, Juan Antonio. Por un derecho penal solo penal: derecho penal, derecho de medidas de seguridad y derecho administrativo sancionador. In: BAJO FERNÁNDEZ, Miguel; JORGE BARREIRO, Agustín; SUÁREZ GONZÁLEZ, Carlos (Coords.). Homenaje al Profesor Dr. Gonzalo Rodríguez. Mourullo. Madrid: Civitas, 2005.

LAURENZO COPELLO, Patricia. El enfoque teleológico-funcional en el sistema del delito. Breves notas sobre su alcance garantístico. In: QUINTERO OLIVARES, Gonzalo; MORALES PRATS, Fermín. El nuevo derecho penal econômico: estudios penales en Memoria del professor José Manuel Valle Muñiz. Pamplona: Aranzadi, 2001.

LEI Maria da Penha é aplicada para proteger homem. Conjur. Disponível em: $<$ http://www.conjur.com.br/2008-out-30/lei_maria_penha_aplicada_proteger_homem>. Acesso em: 12 out. 2011.

LEI Maria da Penha pune também as mulheres. Correio Braziliense. Disponível em: $<$ http://www.correiobraziliense.com.br/app/noticia/brasil/2010/02/21/interna_brasil,17486 7/index.shtml>. Acesso em: 12 out. 2011.

LEI Maria da Penha vale para relação homoafetiva. Disponível em: $<$ http://www.conjur.com.br/2011-abr-20/lei-maria-penha-aplicada-acao-envolvendo-casalhomossexual>. Acesso em: 12 out. 2011.

LEIGH, Leonard Herschel. Strict and vicarious liability: a study in administrative criminal law. London: Sweet and Maxwell, 1982.

The system of administrative and penal sanctions. In: Europäische Kommision: the system of administrative and penal sanctions in the Member States of the European Communities. Luxemburg: National Reports, 1994. v. 1.

LESCH, Heiko. Intervención delictiva e imputación objetiva. Trad. Javier Sánches e Vera Gomez-Trélles. Bogotá: Universidad Externado de Colômbia, 1995.

LEVI, Michael. Perspectives on 'organized crime': an overview. The Howard Journal of Criminal Justice, v. 37, n. 4, p. 335-345, Nov. 1998. 
LISZT, Franz von. Tratado de derecho penal. 3. ed. Trad. Luís Jimenes de Asúa. Madrid: Reus, 1927.

LLEDÓ REAL, Pilar. La inseguridad como causa del racismo y la xenofobia. Revista Catalana de Seguridad Publica, n. 2, abr. 1998.

LOPES CEREZO, José Antônio; LÓPEZ LUJÁN, José Luis. Ciencia y politica del riesgo. Madrid: Alianza, 2000.

LÓPEZ DIAZ, Claudia (Trad.). Código Penal Alemán del 15 de mayo de 1871, con la última reforma del 31 de enero de 1998. Bogotá: Universidad Externado de Colômbia, 1999.

LOZANO CUTANDA, Blanca. Panorámica general de la potestade sancionadora de Administración en Europa: “despenalización” y garantia. Revista de Administración Pública, n. 121, p. 393-414, 1990.

LUNA, Everardo da Cunha. Estrutura jurídica do crime. 2. ed. Recife: Imprensa Universitária - Universidade Federal de Pernambuco, 1968.

LUZÓN PEÑA, Diego Manuel. Curso de derecho penal: parte general. Madrid: Civitas, 1996. v. 1.

MACHADO, Bruno Amaral. Duas "leituras" sobre a construção jurídica da impunidade. Revista de Informação Legislativa, Brasília, ano 43 n. 171, jul./set. 2006.

MACHADO, Marta Rodriguez de Assis. Sociedade de risco e direito penal: uma avaliação de novas tendências político-criminais. São Paulo: IBCCRIM, 2005. (Monografias/IBCCRIM; 34).

MADEIRA, Ronaldo Tanus. A estrutura jurídica da culpabilidade. Rio de Janeiro: Lumen Juris, 1999.

MAGGIORE, Giuseppe. Derecho penal. Prefacio por el Dr. Sebastián Soler. Traducción de la 5 ed. por el padre José J. Ortega Torres. Bogotá: Temis, 1954. v. 1.

MAIER, Julio B. J. ¿Es la reparación una tercera vía del derecho penal? Revista Brasileira de Ciências Criminais, São Paulo, v. 12, n. 50, p. 38-56, set./out. 2004.

MANZINI, Vicenzo. Trattato di diritto penale italiano. Torino: Unione Tipografico Editrice Torinese, 1950. v. 1.

MAR DÍAZ PITA, Madel. El dolo eventual. Valencia: Tirant lo Blanch, 1994.

MARINA, José Antonio. Crónicas de la ultramodernidad. Barcelona: Anagrama, 2000. 
MARINUCCI, Giorgio; DOLCINI, Emilio. Manuale di diritto penale: parte generale. 2. ed. Milano: Giuffrè, 2006.

MATA Y MARTÍN, Ricardo. Bienes jurídicos intermédios y delitos de peligro. Granada: Comares, 1997.

MATTES, Heinz. Problemas de derecho penal administrativo: historia y derecho comparado. Traducción y notas por José Maria Rodriguez Devesa. Madrid: EDERSA, 1979.

MAURACH, Reinhart. Tratado de derecho penal. Trad. 2. ed. (1958) y notas de Derecho español por Juan Córdoba Roda. Barcelona: Ariel, 1963.

. Tratado de derecho penal. Trad. Juan Córdoba Roda. Barcelona: Ariel, 1962. t. 2.

; ZIPF, Heinz. Derecho penal: parte general: teoría general del derecho penal y estructura del hecho punible. 7. ed. Buenos Aires, 1994. t. 1.

MAYER, Max Ernst. Derecho penal: parte general. Traducción por Sergio Politoff Lifschitz. Buenos Aires; Montevidéu: B de F, 2007.

Normas jurídicas y normas de cultura. Traducción por José Luis Guzmán Dálbora. Buenos Aires: Hammurabi, 2000.

MENDONÇA, Nalayne. Penas e alternativas: um estudo sociológico dos processos de agravamento das penas e de despenalização no sistema de criminalização brasileiro (19842004). 1998. Tese (Doutorado) - Programa de Pós-Graduação em Sociologia e Antropologia da UFRJ, Rio de Janeiro, 1998.

MENDOZA BUERGO, Blanca. El derecho penal em la sociedad del riesgo. Madrid: Editora Civitas, 2001.

MESSNER, Steven; ROSENFELD, Richard. Crime and the American dream. Belmont: Wadsworth Pub. Co., 1997.

MEZGER, Edmund. Derecho penal: libro de estúdio: parte general. Traducción de la 6 ed. alemana por Conrado A. Finzi. Buenos Aires: Librería El Foro, 1957. t. 1.

Tratado de derecho penal. Nueva edicion, revisada y puesta al dia por José Arturo Rodriguez Munoz. Madrid: Editorial Revista de Derecho Privado, 1955.

MIR PUIG, Santiago. Derecho penal: parte general. 4. ed. Barcelona: PPU, 1996.

Derecho penal: parte general. 7. ed. 2 reimpr. Buenos Aires; Montevidéu: B de F, 
MIR PUIG, Santiago. Derecho penal: parte general. 8. ed. Barcelona: Editorial Reppertor, 2008.

. Introducción a las bases del derecho penal. Bosch: Barcelona, 1976.

La distinción de error de tipo y error de prohibición en derecho penal. In: CGPJ Consejo General del Poder Judicial Derecho Judicial (Ed.). El consentimiento. El error. Madrid, 1993.

. Valoración, normas y antijuridicidad penal. In: DIEZ DIPOLLÉS, J. L.; ROMEO CASABONA, C. M.; GRACIA MARTIN, L.; HIGUERA GUIMERÁ, J. F. (Eds.). La ciencia del derecho penal ante el nuevo siglo: libro homenaje al prof. Dr. D. José Cerezo Mir. Madrid: Tecnos, 2002.

MOCCIA, Sérgio. De la tutela de bienes a la tutela de funciones: entre ilusiones postmodernas y reflujos iliberales. In: SILVA SÁNCHEZ, Jesús-María (Org). Política criminal y nuevo derecho penal. Barcelona: Bosch, 1997.

MOLINA FERNANDEZ, Fernando. Antijuridicidad penal y sistema del delito. Madrid: Civitas, 2001.

MOMMSEN, Teodoro. Derecho penal romano. Trad. P. Dorado. Reimpressão. Bogotá: Temis, 1999.

MORO, Aldo. La antijuridicidad penal. Traducción directa del italiano por Diego A. Santillan. Buenos Aires: Editorial Atalaya, 1949.

MOTTA, Ivan Martins. Erro de proibição e bem jurídico-penal. São Paulo: Ed. Revista dos Tribunais, 2009.

MUGUERZA, Javier. El tribunal de la conciência y la conciência del tribunal (uma reflexión ético-jurídica sobre la ley y la consciência). Doxa, n. 15/16, 1994.

MÜLLER-TUCKFELD, Jean Christian. Ensayo para la abolición del derecho penal del medio ambiente. In: INSTITUTO DE CIENCIAS CRIMINALES DE FRANKFURT (Ed.). La insostenible situación del derecho penal. Granada: Comares, 2007.

MUNHOZ NETTO, Alcides. Erro de fato e erro de direito no Anteprojeto de Código Penal. Revista da Faculdade de Direito da UFPR, n. 9, nov. 2006. Disponível em: <http://ojs.c3sl.ufpr.br/ojs2/index.php/direito/article/view/6695/4795>. Acesso em: 14 abr. 2012.

A ignorância da antijuridicidade em matéria penal. Rio de Janeiro: Forense, 1978. 
MUÑOZ CONDE, Francisco. Bases para una teoría del error orientado a las consecuencias. La Ley, v. 1, p. 1040-1052, 1991.

- La creencia errónea de estar obrando lícitamente. Estudios Penales y Criminológicos, Santiago de Compostela, v. 10, 1987.

. El error en el delito de defraudación tributaria del art. 349 del Código. ADPCP, 1986.

. El error en derecho penal. Valencia, Tirant lo Blanch, 1989.

. Teoría general del delito. 2. ed. Bogotá: Temis, 2008.

; GARCIA ARÁN, Mercedes. Derecho penal: parte general. 2. ed. Valencia: Tirant Lo Blanch, 1996.

; ___ Derecho penal: parte general. 7. ed. rev. y puesta al día. Valencia: Tirant lo Blanch, 2007.

MUÑOZ MACHADO, Santiago; GARCIA DELGADO, José Luis; GONZÁLES SEARA, Luis. (Dir.). Las estructuras del bienestar en Europa. Madrid: Escuela Libre Editorial, 2000.

MÜSSIG, Bernard. Desmaterialización del bien jurídico y de la política criminal. Sobre las perspectivas y los fundamentos de una teoría del bien jurídico crítica hacia el sistema. Revista de Derecho Penal y Criminología, n. 9, p. 169-208, 2002.

NAVARRO CARDOSO, Fernando. Infracción administrativa y delito: limites de intervención del derecho penal. Madrid: Colex, 2001.

NEUMAN, Ulfrid. O princípio da proporcionalidade como princípio limitador da pena. Trad. Alfredo Martins. Revista Brasileira de Ciências Criminais, São Paulo, n. 71, mar./abr. 2008.

NIETO GARCÍA, Alejandro. Derecho administrativo sancionador. 4. ed. totalmente reformada. Madrid: Tecnos, 2005. Reimpression 2006.

. El conocimiento del derecho: un estudio sobre la vencibilidad del error de prohibición. Barcelona: Atelier, 1999.

Fraudes comunitários. Derecho penal económico europeo. Barcelona: Praxis, 1996. 
80 MIL presos serão soltos no Brasil a partir do dia 5. Brasil 247. Disponível em: <http://brasil247.com.br/pt/247/brasil/6044/80-mil-presos-ser\%C3\%A3o-soltos-no-Brasila-partir-do-dia-5.htm>. Acesso em: 09 out. 2011.

OLAIZOLA NOGALES, Inés. El error de prohibición: especial atención a los criterios para su apreciación y para la determinación de su vencibilidad e invencibilidad. Madrid: La Ley, 2007.

ORTEGA Y GASSET, José. La rebelión de las masas. Madrid: P. Garagorri, 1988.

OSÓRIO, Fabio Medina. Direito administrativo sancionador. São Paulo: Ed. Revista dos Tribunais, 2000.

PADOVANI, Tullio. Alle radici di un dogma: appunti sulle origini dell'antigiuridicità oggettiva. Rivista Italiana di Diritto e Procedura Penale, Milano, nuova serie, anno 26, p. 532-558, 1983.

PAGLIARO, Antonio. Trattato di diritto penale: il reato. Milano: Giuffrè, 2007. v. 2.

; TRANCHINA, Giovanni. Istituzioni di diritto e procedura penale. Milano: Giuffrè, 2000.

PALIERO, Carlo Enrico. Metodologia de lege ferenda: per una riforma non improbabile del sistema sazionatorio. Rivista Italiana di Diritto e Procedura Penale, Milano, n. 12, 1992.

L'autunno del patriarca. Rivista Italiana di Diritto e Procedura Penale, Milano, v. 37, t. 2, p. 1220-1250, 1994.

PARADA VÁZQUEZ, José Ramón. Evolución y constitucionalización de las infracciones administrativas. Poder Judicial, n. 4, 1982.

. El poder sancionador de la Administración y la crisis del sistema judicial penal. Revista de Administración Pública, n. 67, 1972.

PARDO, José Esteve. Tecnica, riesgo y derecho. Barcelona: Ariel, 1999.

PAREDES CASTAÑÓN, José M. Recensión: GRACIA MARTÍN, Luis. Prolegómenos para la lucha por la modernización y expansión del derecho penal y para la crítica del discurso de resistência.” Política Criminal, v. 1, n. 2, p. 1-27, dic. 2006.

PAREJO ALFONSO, Luciano. Prólogo. In: DOMINGUEZ VILA, Antonio. Constitución y derecho administrativo sancionador. Madrid: Marcial Pons, 1977. 
PASCHOAL, Janaína Conceição. A constituição do crédito tributário, a consumação do crime tributário e a extinção da punibilidade pela prescrição. Boletim IBCCRIM, São Paulo, v. 16, n. 194, p. 2-3, jan., 2009.

Constituição, criminalização e direito penal mínimo. São Paulo: Ed. Revista dos Tribunais, 2003.

PECES-BRABA, Gregorio. Los valores superiores. Tecnos: Madrid, 1984.

PÉREZ ALONSO, Esteban Juan. La duda sobre la prohibición: especial consideración de la jurisprudência del Tribunal Supremo. Anuário de Derecho Penal y Ciencias Penales, ADPCP, Madrid, v. 48, n. 1, ene./abr. 1995.

PÉREZ ROYO, Fernando. Infracciones y sanciones tributárias. Sevilla: Instituto de Estudios Fiscales, 1972.

PERIS RIERA, Jaime Miguel. El proceso despenalizador. Valencia: Universidad de Valencia, 1983.

PILAR Lledó Real. Disponível em: <www.pilarlledo.es>.

PINTO, Costa. O ilícito de mera ordenação social e a erosão do princípio da subsidiariedade da intervenção penal, direito penal económico e europeu: textos doutrinários. Coimbra: Coimbra Ed., 1998. v. 1.

PIPPER, Cristine. The crime and disorder act 1998: child and community "safety". Modern Law Review, n. 62, 1999.

PONTE, Antonio Carlos da. Crimes eleitorais. São Paulo: Saraiva, 2008.

PORTILLA CONTRERAS, Guillermo. El derecho penal y procesal del enemigo: las viejas y nuevas políticas de seguridad frente a los peligros internos-externos. In: LÓPEZ BARJA DE QUIROGA, Jacobo; ZUGARLDÍA ESPINAR, José Miguel (Eds.). Dogmática y ley penal: libro homenaje a Enrique Bacigalupo. Madrid: Instituto Universitario de Investigación Ortega Y Gasset; Marcial Pons, 2004. p. 693-720.

La legislación de lucha contra las no-personas: represión legal del 'enemigo’ tras el atentado del 11 de septiembre de 2001. Mientras Tanto, n. 83, p. 77-91, 2002.

PRADO, Luiz Régis. Bem jurídico-penal e Constituição. 2. ed. São Paulo: Ed. Revista dos Tribunais, 1997.

Curso de direito penal brasileiro: parte geral. 3. ed. São Paulo: Ed. Revista dos Tribunais, 2002. 
PRIETO DEL PINO, Ana María. El derecho penal ante el uso de información privilegiada en el mercado de valores. Cizur Menor: Thomson-Aranzadi, 2004.

PRITTWITZ, Cornelius. El derecho penal alemán: ¿fragmentario? ¿subsidiario? ¿ultima ratio? Reflexiones sobre la razón y límites de los principios limitadores del derecho penal. Trad. por María Teresa Castiñeira. In: INSTITUTO DE CIENCIAS CRIMINALES DE FRANKFURT (Ed.). La insostenible situación del derecho penal. Granada: Comares, 2000.

QUEIROZ, Paulo. Direito penal: parte geral. 6. ed. Rio de Janeiro: Lumen Juris, 2010.

QUINTERO OLIVARES, Gonzalo. La deriva y crisis de las ideas penales y de la política criminal en España: libro homenaje a Ruiz Antón. Universidad de Extremadura, 2004. Locos y culpables. Pamplona: Aranzadi, 1999.

RAMACCI, Fabrizio. Istituzioni di diritto penale. Corredato di nota di aggiornamento. Torino: G. Giappichelli, 1988.

RANDO CASERMEIRO, Pablo. La distinción entre el derecho penal y el derecho administrativo sancionador. Valencia: Tirant lo Blanch, 2010.

RAZ, Joseph. Razón práctica y normas. Trad. Juan Ruiz Manero. Madrid: Centro de Estudios Constitucionales, 1999. (Colección El Derecho y la Justicia).

REALE JÚNIOR, Miguel. Despenalização no direito penal econômico: uma terceira via entre o crime e a infração administrativa? Revista Brasileira de Ciências Criminais, São Paulo, v. 7, n. 28, p. 116-129, out./dez. 1999.

- Ilícito administrativo e jus puniendi geral. In: PRADO, Luiz Régis (Coord.). Direito penal contemporâneo: estudos em homenagem ao professor José Cerezo Mir. São Paulo: Ed. Revista dos Tribunais, 2007.

. Instituições de direito penal: parte geral. Rio de Janeiro: Forense, 2002.

Instituições de direito penal: parte geral. 3. ed. Rio de Janeiro: Forense, 2009.

. A lei de crimes ambientais. Revista Forense, Rio de Janeiro, v. 95, n. 345, p. 121-

127, jan./mar. 1999.

Teoria do delito. São Paulo: Ed. Revista dos Tribunais, 1998.

Teoria do delito. 2. ed. rev. São Paulo: Ed. Revista dos Tribunais, 2000. 
REBOLLO PUIG, Manuel. Potestad sancionadora, alimentación y salud pública. Madrid: Ministério para las Administraciones Públicas, 1989. (Serie administración del Estado).

REINER, Robert. Media made criminality: the representation of crime in the mass media. In: MAGUIRE, Mike; MORGAN, Rod; REINER, Robert (Eds.). Oxford Handbook of criminology. 2. ed. Oxford: Oxford University Press, 1997.

RIGHI, Esteban. Derecho penal económico comparado. Madrid. EDERSA, [s.d.].

RIVERA BEIRAS, Iñaki. Historia e legitimación del castigo. Hacia dónde vamos? In: BERGALLI, Roberto (Coord.). Sistema penal y problemas sociales. Valencia: Tirant lo Blanch, 2003. p. 86-137.

(Coord.). Política criminal y sistema penal. Barcelona: Anthropos, 2005.

ROCCO, Arturo. El problema y el método de la ciencia del derecho penal. Versión de Rodrigo Naranjo Vallejo. Bogotá: Temis, 1982.

RODRÍGUEZ MOURULLO, Gonzalo. Derecho penal: parte general. Madrid: Civitas, 1978.

ROXIN, Claus. Derecho penal: parte general. 2. ed. Trad. Diego-Manuel Luzón Peña, Miguel Diaz e Garcia Conlledo e Javier de Vicente Remesal. Madrid: Civitas, 1997. t. 1.

Derecho penal: parte general. 5 reimpr. Traducción de la 2 ed. alemana por Diego-Manuel Luzón Peña, Miguel Días, García Conlledo y Javier de Vicente Remesal. Madrid: Civitas, 2008. t. 1.

El desarollo del derecho penal e el seguinte siglo. In: . Dogmática penal y política criminal. Trad. Manuel Abanto Vasquez. Lima: Idemsa, 1998.

Politica criminal y sistema del derecho penal. 2. ed. 1. reimpr. Traducción e introducción de Francisco Muñoz Conde. Buenos Aires: Hammurabi, 2002.

. Política criminal e sistema jurídico-penal. Trad. Luis Greco. Rio de Janeiro: Renovar, 2000.

SAINZ CANTERO, José. La ciencia del derecho penal y su evolución. Barcelona: Bosch, 1975.

SÁNCHEZ GARCÍA DE PAZ, Isabel. La criminalidad organizada: aspectos penales, procesales, administrativos y policiales. Madrid: Dickinson, 2005. 
SANCINETTI, Marcelo. Prólogo. Homenage a la memoria de Hans Welzel a los 20 años de su fallecimiento. In: JAKOBS, Gunther; STRUENSSE, Eberhard. Problemas capitales del derecho penal moderno: libro homenagem a Hans Welzel. Buenos Aires: Hamurabi, 1998.

SANTOS, Juarez Cirino dos. Direito penal: parte geral. 2. ed. Rio de Janeiro: Lumen Juris, 2007.

. A moderna teoria do fato punível. Rio de Janeiro: Freitas Bastos, 2000.

SANZ DELGADO, Enrique, Las prisiones privadas: la participación privada en la ejecución penitenciaria. Madrid: Ed. Edifoser, 2000.

SAUER, Guillermo. Derecho penal; parte general. Traducción directa del alemán por Juan del Rosal y José Cerezo. Barcelona: Bosch, 1956.

SCHIAFFO, Francesco. Riflessioni critiche intorno ad un dogma: l'antigiuridicità genérica. Rivista Italiana di Diritto e Procedura Penale, Milano, anno 42, fasc. 3, p. 10751097, lugl./sett. 1999.

SCHÜNEMANN, Bernd. Obras. Buenos Aires: Rubinzal - Culzoni Editores, 2009. t. 1.

. El sistema moderno de derecho penal: cuestiones fundamentales. Trad. e introd. Jesús-Maria Silva Sanchez. Madrid: Tecnos, 1991.

SEARLE, John Rogers. Actos de habla: ensayo de filosofia del lenguaje. Madrid: Planeta, 1980.

SEELMANN, Kurt. Societat de risc i dret. Iuris. Quaderns de Política Jurídica, Barcelona, n. 1, 1994.

SGUBBI, Filippo. El delito como riesgo social: investigación sobre las opciones en la asignación de la ilegalidad penal. Buenos Aires: Editorial Ábaco, 1998.

SILVA, Antonio José Costa e. Codigo Penal dos Estados Unidos do Brasil commentado. São Paulo: Companhia Ed. Nacional, 1930.

SILVA SÁNCHEZ, Jesús-Maria. Aproximación al derecho penal contemporáneo. Barcelona: Bosch, 1992.

Aproximación al derecho penal contemporáneo. Buenos Aires; Montevidéu: B de F, 2010.

A expansão do direito penal: aspectos da política criminal nas sociedades pósindustriais. 2. ed. São Paulo: Ed. Revista dos Tribunais, 2010. 
SILVA SÁNCHEZ, Jesús-Maria. La expansión del derecho penal. Madrid: Civitas, 2001. La expansión del derecho penal: aspectos de la política criminal en las sociedades post industriales. Madrid: Civitas, 1999.

Observaciones sobre el conocimiento eventual de la antijuridicidad. Anuario de Derecho Penal y Ciencias Penales, Madrid, v. 40, n. 3, sept./dic. 1987.

Política criminal moderna? Consideraciones a partir de los ejemplos urbanísticos en el nuevo Codigo Penal Español. Actualidad Penal, n. 23, 1998.

Sobre el conocimiento eventual de la antijuricidad. Anuario de Derecho Penal y Ciencias Penales - ADPCP, Madrid, jun. 1987.

SILVEIRA, Renato de Mello Jorge. Crimes sexuais: bases críticas para a reforma do direito penal sexual. São Paulo: Quartier Latin, 2008.

Direito penal econômico como direito penal de risco. São Paulo: Ed. Revista dos Tribunais, 2006.

Direito penal supra-individual: interesses difusos. São Paulo: Ed. Revista dos Tribunais, 2003.

SIMON, Jonathan. The emergence of a risk society: insurance, law, and the state. Socialist Review, n. 95, 1987.

SMART, Barry. Post modernity. London; New York: Routledge, 1993.

SOARES, Bárbara Musumeci. Mulheres invisíveis: violência conjugal e as novas políticas de segurança. Rio de Janeiro: Civilização Brasileira, 1999.

SOUZA, Luciano Anderson de. Direito penal econômico: fundamentos, limites e alternativas. São Paulo: Quartier Latin, 2012.

SOUZA, Maria de Lourdes. La individualización post moderna. Anuário de Filosofia del Derecho, 1999.

STRATENWERTH, Günther. Derecho penal: parte general: el hecho punible. 2. ed. Trad. Gladys Romero. Madrid: Edersa, 1982. v. 1.

SUAY HERNÁNDEZ, Celia. Los delitos contra la salubridad y seguridad del consumo en el marco de las relaciones entre derecho penal y el derecho administrativo sancionador. Cuadernos e Derecho Judicial, n. 11, p. 123-173, 1997. 
SUAY HERNÁNDEZ, Celia. Los elementos normativos y el error. Anuário de Derecho Penal y Ciencias Penales, ADPCP, Madrid, t. XLIV, fasc. 1, p. 97-142, 1991.

SUAY RINCÓN, José. El derecho administrativo sancionador: perspectivas de reforma. Revista de Administración Pública, n. 109, 1986.

SUPERIOR TRIBUNAL DE JUSTIÇA. Esclarecimentos à sociedade. Disponível em: $<$ http://www.stj.jus.br/portal_stj/publicacao/engine.wsp?tmp.area=398\&tmp.texto=105290>. Acesso em: 06 abr. 2012.

SWAANINGEN, René van. Critical criminology: visions from europeu. London: SAGE, 1997.

SYMEONIDOU-KASTANIDOU, Elisabeth. Towards a new definition of organized crime in the European Union. European Journal of Crime, Criminal Law and Criminal Justice, v. 15, n. 1, p. 83-103, 2007.

TANGERINO, Davi de Paiva Costa. Culpabilidade. Rio de Janeiro: Campus Jurídico; Elsevier, 2011.

TAVARES, Juarez. Culpabilidade: a incongruência dos métodos. Revista Brasileira de Ciências Criminais, São Paulo, ano 6, n. 24, out./dez. 1998.

Teoria do injusto penal. 3. ed. Belo Horizonte: Del Rey, 2000.

TIEDEMAN, Klaus. Poder económico y delito. Barcelona: Ariel, 1985.

TOLEDO, Francisco de Assis. Culpabilidade e a problemática do erro jurídico-penal. Revista dos Tribunais, São Paulo, v. 517, dez. 1978.

. O erro no direito penal. São Paulo: Saraiva, 1977.

Ilicitude penal e causas de sua exclusão. Rio de Janeiro: Forense, 1984.

. Princípios básicos de direito penal. São Paulo: Saraiva, 1985.

. Princípios básicos de direito penal. 5. ed. São Paulo: Saraiva, 1994.

TORÍO LÓPEZ, Ángel. El error evitable de prohibición en el Proyecto de Código Penal. Indicaciones de política legislativa sobre la «Teoría de la culpabilidad». In: LA REFORMA penal y penitenciaria (Cursos y congresos de la Universidad de Santiago de Compostela). Santiago de Compostela: Universidad, 1980.

. El "error iuris“, perspectivas materiales y sistemáticas. Anuário de Derecho Penal y Ciencias Penales, ADPCP, Madrid, 1975. 
TORON, Alberto Zacharias. Aspectos penais da proteção ao consumidor. Revista Brasileira de Ciências Criminais, v. 3, n. 11, p. 80-90, jul./set. 1995.

TRUJILLO, Manuel. El fin de la great Society? ABC, 07 nov. 2000. Disponível em: $<$ www.abc.es $>$.

VALENTE, Maria Inês Trefiglio; SILVEIRA, Renato de Mello Jorge (Colabs). Críticas à lei de assédio sexual: Lei n. 10.224/01. Boletim IBCCRIM, São Paulo, v. 9, n. 103, jun. 2001.

VARGAS, José Cirilo de. Do tipo penal. 3. ed. Rio de Janeiro: Lumen Juris, 2008. Instituições de direito penal: parte geral. Belo Horizonte: Del Rey, 1997. t. 1.

VENTURA PÜSCHEL, Arturo. Sobre el conocimiento de algunos elementos del tipo en los delitos especiales. PJ, (2b), p. 161-178, 1993.

WATKINS, Tony. Faking it: the sentimentalization of modern society. London: The Social Affair is Unit, 1998.

WELZEL, Hans. Derecho penal alemán. Trad. de la 11. ed. alemana por Juan Bustos Ramírez y Sergio Yáñez Pérez. Santiago de Chile: Editorial Jurídica de Chile, 1970.

- Derecho penal alemán. Trad. Juan Bustos Ramirez y Sergio Yañez Pérez. Santiago: Ed. Jurídica de Chile, 1987.

- Derecho penal alemán: parte general. Traducción de Juan Bustos Ramírez y Sergio Yáñez Pérez. 4. ed. Santiago de Chile: Editorial Jurídica de Chile, 1997.

Derecho penal: parte general. Traduccion del aleman por Carlos Fontan Balestra. Buenos Aires: Depalma, 1956.

O novo sistema jurídico-penal: uma introdução à doutrina da ação finalista. Tradução, prefácio e notas de Luiz Regis Prado. São Paulo: Ed. Revista dos Tribunais, 2001.

El nuevo sistema de derecho penal: una introducción a la doctrina de la acción finalista. Versión castellana y notas por José Cerezo Mir. Barcelona: Ariel, 1964.

El nuevo sistema del derecho penal: una introducción a la doctrina de la acción finalista. Traducción y notas por José Cerezo Mir. 3. reimpr. Buenos Aires; Montevidéu: B de F, 2006. 
WOLTER, Jürgen. Las causas constitucionales de exclusión del tipo, de injusto y de punibilidad como cuestión central de la teoría del delito en la actualidad. In: MIR PUIG, Santiago; LUZÓN PEÑA, Diego-Manuel; DÍAZ Y GARCÍA CONLLEDO, Miguel (Dir.). Cuestiones actuales de la teoría del delito. Trad. Juan Manuel Paredes Castañón. Madrid: Interamericana de España; McGraw Hill, 1999.

ZAFFARONI, Eugênio Raúl; ALAGIA, Alejandro; SLOKAR, Alejandro. Manual de derecho penal: parte general. 2. ed. Buenos Aires: Ediar, 2006.

; PIERANGELI, José Henrique. Manual de direito penal brasileiro: parte geral. 9. ed. São Paulo: Ed. Revista dos Tribunais, 2011. v. 1.

ZIPF, Heinz. Introducción a la política criminal. Trad. De Miguel Izquierdo MacíasPicavea. Madrid: Edersa, 1979.

ZUÑIGA RODRÍGUEZ, Laura. Bases para un modelo de imputación de responsabilidad penal a las personas jurídicas. Navarra: Aranzadi, 2003.

Politica criminal. Madrid: Colex, 2001. 